\title{
LESZEK KUCHARSKI
}

\section{Bezrobocie równowagi W Polsce}


盗 
LESZEK KUCHARSKI

\section{Bezrobocie równowagi w Polsce}

\section{Ujęcie teoretyczne \\ i empiryczne}

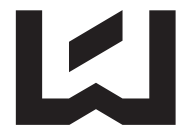

WYDAWNICTWO

ŁóDź 2014 
Leszek Kucharski - Uniwersytet Łódzki, Wydział Ekonomiczno-Socjologiczny Instytut Ekonomii, Katedra Makroekonomii, 90-214 Łódź, ul. Rewolucji 1905 r. nr 41/43 e-mail: lekuchar@uni.lodz.pl

\author{
RECENZENT \\ Wacław Jarmołowicz \\ REDAKTOR WYDAWNICTWA UŁ \\ Dorota Stępień
}

SKŁAD I ŁAMANIE

AGENT PR

OKŁADKĘ PROJEKTOWAŁA

Barbara Grzejszczak

(C) Copyright by Uniwersytet Łódzki, 2014

Wydane przez Wydawnictwo Uniwersytetu Łódzkiego
Wydanie I. W.06444.13.0.H

ISBN (wersja papierowa) 978-83-7969-108-1

ISBN (ebook) 978-83-7969-690-1

Wydawnictwo Uniwersytetu Łódzkiego

90-131 Łódź, ul. Lindleya 8

www.wydawnictwo.uni.lodz.pl

e-mail: ksiegarnia@uni.lodz.pl

tel. (42) 6655863 , faks (42) 6655862 


\section{Spis treści}

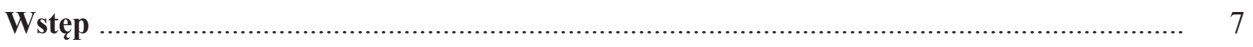

Rozdział 1. Bezrobocie równowagi oraz jego determinanty - ujęcie teoretyczne ............... 11

1.1. Bezrobocie równowagi jako jeden z typów bezrobocia ......................................... 12

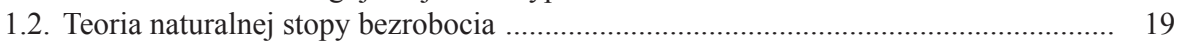

1.2.1. Koncepcja E. S. Phelpsa _........................................................................ 20

1.2.2. Koncepcja naturalnej stopy bezrobocia M. Friedmana ................................. 34

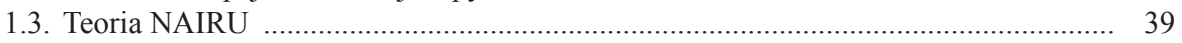

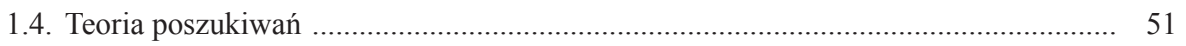

1.5. Teoria bezrobocia równowagi Ch. A. Pissaridesa .................................................. 56

1.6. Strukturalistyczna teoria bezrobocia E. S. Phelpsa .................................................. 59

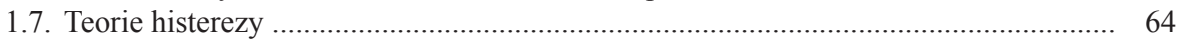

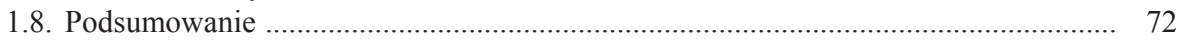

Rozdział 2. Bezrobocie w Polsce w latach 1995-2012 i jego determinanty ......................... 75

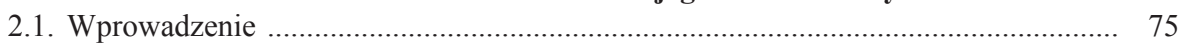

2.2. Tendencje zmian w poziomie i dynamice bezrobocia .......................................... 77

2.3. Czas trwania bezrobocia ................................................................................ 80

2.4. Zróżnicowanie stóp bezrobocia w wybranych grupach siły roboczej ....................... 85

2.5. Przestrzenne zróżnicowanie bezrobocia ............................................................. 87

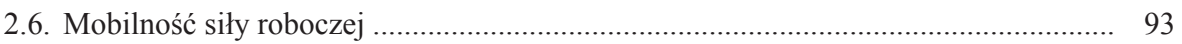

2.7. Niedopasowania strukturalne …....................................................................... 98

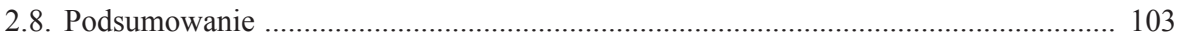

Rozdzial 3. Metody pomiaru bezrobocia równowagi oraz wyniki oszacowań stóp bezrobocia NAIRU dla wybranych krajów Europy Środkowo-Wschodniej ........................... 105

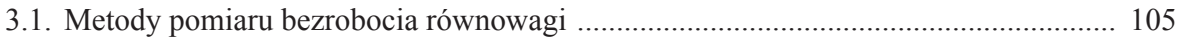

3.1.1. Metody oparte na przepływach siły roboczej .................................................. 106

3.1.2. Metody oparte na krzywej Phillipsa ............................................................ 116

3.1.3. Metody oparte na krzywej Beveridge'a ........................................................ 121

3.1.4. Metody oparte na szacunkach produkcji potencjalnej ................................... 123

3.2. Szacunki bezrobocia równowagi dla wybranych krajów Europy Środkowo-

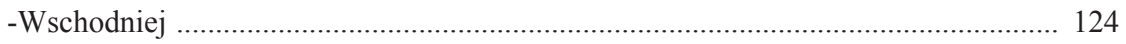

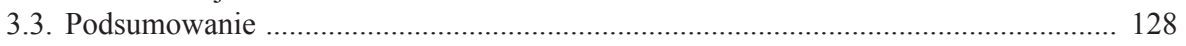

Rozdzial 4. Oszacowania poziomu bezrobocia równowagi w Polsce ................................... 129

4.1. Przegląd opublikowanych wyników oszacowań poziomu bezrobocia równowagi

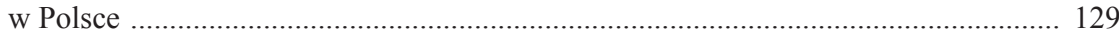

4.2. Własne wyniki oszacowań stóp bezrobocia NAIRU w Polsce w oparciu o metody przepływów siły roboczej w latach 1993-2009 ....................................................... 140

4.3. Własne wyniki oszacowań stóp bezrobocia NAIRU w oparciu o rozszerzoną krzywą Phillipsa 


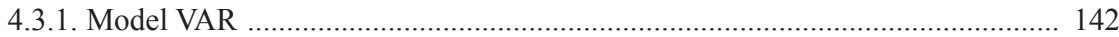

4.3.2. Wykorzystane dane statystyczne ................................................................ 144

4.3.3. Wyniki oszacowań NAIRU dla Polski ........................................................... 148

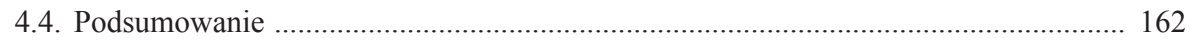

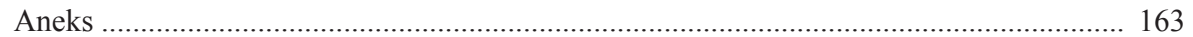

Rozdział 5. Bezrobocie równowagi a polityka makroekonomiczna w Polsce …................... 177

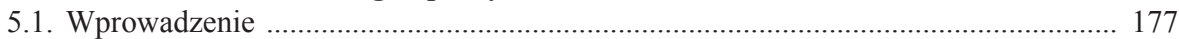

5.2. Polityka pieniężna a bezrobocie równowagi .......................................................... 177

5.2.1. Pojęcie i miary restrykcyjności polityki pieniężnej ....................................... 177

5.2.2. Charakter polityki pieniężnej a tendencje zmian bezrobocia równowagi w latach $1997-2011$.......................................................................... 182

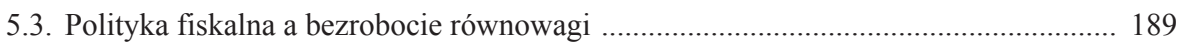

5.3.1. Pojęcie i miary restrykcyjności polityki fiskalnej .......................................... 189

5.3.2. Stopień restrykcyjności polityki fiskalnej a bezrobocie równowagi ................. 192

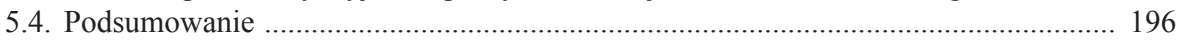

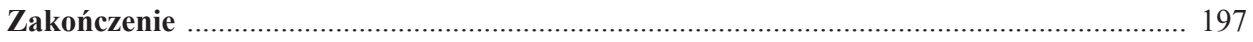

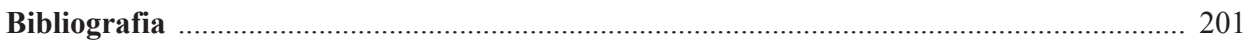

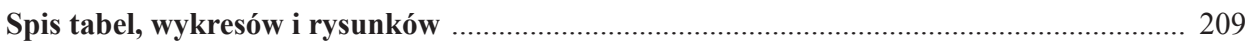

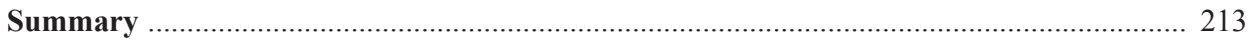

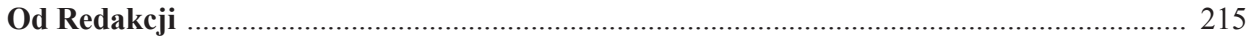




\section{Wstęp}

Badania nad bezrobociem oraz jego typami mają w teorii ekonomii już dosyć długą tradycję. Już w czasach ekonomii klasycznej zwrócono uwagę na zjawisko nadmiaru ludności, wiążąc je z nadwyżką podaży pracy nad popytem na pracę. Dużą uwagę poświęcił problemowi bezrobocia Karol Marks. Bezrobocie określał on mianem „rezerwowej armii pracy” oraz „przeludnienia względnego”. Wyodrębnił następujące formy przeludnienia względnego: przeludnienie płynne, przeludnienie ukryte i przeludnienie chroniczne. Mechanizmy powstawania tych typów bezrobocia przypominają mechanizmy powstawania bezrobocia frykcyjnego, ukrytego oraz długookresowego. Ekonomiści neoklasyczni zwracali uwagę, że przyczyną powstawania bezrobocia są ograniczenia w swobodnym działaniu mechanizmów rynkowych. Stosunkowo dużo uwagi poświęcił bezrobociu John Maynard Keynes, eksponując w swych analizach bezrobocie cykliczne. Pod koniec lat 60 . XX w. została wysunięta koncepcja naturalnej stopy bezrobocia, która miała zasadnicze znaczenie dla idei bezrobocia równowagi. Ta koncepcja, Miltona Friedmana i Edmunda S. Phelpsa, stała się punktem wyjścia dla rozwoju badań nad bezrobociem równowagi.

Bezrobocie równowagi jest złożoną koncepcją teoretyczną mającą swoje rozwinięcie w szkołach głównego nurtu ekonomii. Koncepcje szeroko rozumianego bezrobocia równowagi zostały rozwinięte przez czołowych przedstawicieli szkoły monetarystycznej i nowej szkoły keynesowskiej. Wielkość bezrobocia równowagi jest bezpośrednio trudno mierzalna, dlatego powstaje problem oszacowania jego wielkości. Istnieje kilka sposobów szacowania wielkości bezrobocia równowagi, różniących się podstawami teoretycznymi i wykorzystywanymi formułami matematycznymi. Stosowanie różnych metod pomiaru powoduje, że ich efektem są często dosyć rozbieżne wyniki szacunków bezrobocia równowagi. Dokładność tych szacunków ma istotne znaczenie dla polityki makroekonomicznej, a w szczególności polityki pieniężnej. Im wyższy jest poziom bezrobocia równowagi, tym wyższe są koszty społeczne prowadzenia polityki antyinflacyjnej.

W literaturze ekonomicznej można spotkać różne terminy na określenie bezrobocia równowagi. Występują m.in. takie określenia, jak: NAIRU, czyli stopa bezrobocia nieprzyspieszająca inflacji; NAWRU, czyli stopa bezrobocia nieprzyspieszająca wzrostu płac oraz naturalna stopa bezrobocia, czyli stopa bezrobocia w warunkach równowagi na rynku pracy. 
Do podjęcia problematyki bezrobocia równowagi skłoniły mnie następujące powody. Po pierwsze, poziom tego bezrobocia ma zasadnicze znaczenie dla polityki makroekonomicznej. Jeśli rośnie różnica między bezrobociem faktycznym a szeroko rozumianym bezrobociem równowagi, to wówczas wzrasta udział bezrobocia koniunkturalnego w bezrobociu ogółem. Stwarza to możliwość poluzowania polityki fiskalnej i pieniężnej. Po drugie, w dalszym ciągu niewiele jest opracowań w Polsce dotyczących bezrobocia równowagi. Po trzecie, poziom oraz struktura tego bezrobocia jest miernikiem sprawności funkcjonowania rynku pracy. Po czwarte, utrzymujący się wysoki poziom bezrobocia równowagi w Polsce może wskazywać na zbyt niskie zainteresowanie inwestycjami w kapitał ludzki.

Teoretyczne analizy bezrobocia równowagi były podejmowane w Polsce m.in. przez: M. Sochę i U. Sztanderską (2000), E. Kwiatkowskiego (1988), (2002b), (2009), W. Jarmołowicza i B. Woźniak (2005), B. Woźniak (2008).

Problematyka dotycząca bezrobocia równowagi w Polsce jest stosunkowo rzadko podejmowana w badaniach empirycznych. Szacunki bezrobocia równowagi dla Polski podejmowane były m.in. przez takich ekonomistów, jak: M. Socha i U. Sztanderska (2000), E. Kwiatkowski, T. Tokarski, L. Kucharski (2002), J. Socha i W. Wojciechowski (2004), M. Góra (1998), G. Kuczyński i K. Strzała (2006), P. Krajewski (2006), K. B. Budnik (2006), R. Kelm (2009), L. Kucharski (2006), (2009), (2012), K. Leszkiewicz-Kędzior i W. Welfe (2012). Szacunki bezrobocia równowagi dla Polski i nowych krajów UE można także znaleźć w opracowaniu M. Camarero, J. L. Carrion-i-Silvestre oraz C. Tamarit (2005).

Głównym celem pracy jest określenie istoty, uwarunkowań i determinant bezrobocia równowagi oraz oszacowanie poziomu bezrobocia równowagi w polskiej gospodarce. Celem dodatkowym jest określenie znaczenia zmienności bezrobocia równowagi dla polityki makroekonomicznej. Oszacowania stóp szeroko rozumianego bezrobocia równowagi zostaną przeprowadzone w oparciu o metody przepływów siły roboczej oraz rozszerzoną krzywą Phillipsa.

Analizy pojęciowe i teoretyczne zostały oparte na publikacjach naukowych (artykułach i książkach) polskich i zagranicznych ekonomistów zajmujących się problematyką bezrobocia $\mathrm{w}$ ogóle, a bezrobocia równowagi w szczególności. Przedstawione zostaną teorie: M. Friedmana; E. S. Phelpsa; R. Layarda, S. Nickella i R. Jackmana oraz Ch. A. Pissaridesa.

W analizach empirycznych wykorzystywane są dane agregatowe o bezrobociu i przepływach osób na rynku pracy pochodzące z Głównego Urzędu Statystycznego oraz dane jednostkowe z Badań Aktywności Ekonomicznej Ludności. Zastosowane zostały również metody ekonometryczne. W celu oszacowania poziomu stopy bezrobocia NAIRU wykorzystano model wektorowo-autoregresyjny (VAR).

Książka składa się z pięciu rozdziałów, wstępu oraz zakończenia. W rozdziale pierwszym, oprócz zagadnień pojęciowych, przeprowadzono analizę krytyczną najważniejszych koncepcji bezrobocia równowagi, a mianowicie: teorii 
naturalnej stopy bezrobocia E. S. Phelpsa oraz M. Friedmana, teorii NAIRU, teorii poszukiwań, teorii bezrobocia równowagi Ch. A. Pissaridesa, strukturalistycznej teorii bezrobocia E. S. Phelpsa oraz teorii histerezy. Pominięte zostały te współczesne teorie bezrobocia, których przedmiotem zainteresowania nie jest bezrobocie równowagi, takie jak np. teoria płacy efektywnej oraz teoria niepisanych kontraktów płacowych.

Rozdział drugi ma charakter empiryczny. Przedstawiono w nim tendencje oraz uwarunkowania i determinanty bezrobocia w Polsce w latach 1995-2012. Zaprezentowano tendencje zmian poziomu i dynamiki bezrobocia oraz poziom bezrobocia długookresowego. Ponadto, podjęto próbę odpowiedzi na pytanie, jakie grupy siły roboczej były najbardziej zagrożone bezrobociem długookresowym w badanym okresie. Przeprowadzono analizę zróżnicowania stóp bezrobocia w wybranych grupach siły roboczej i analizę przestrzennego zróżnicowania bezrobocia. Zawarto też rozważania dotyczące poziomu mobilności siły roboczej i przedstawiono zmiany poziomu niedopasowań strukturalnych na rynku pracy w Polsce.

Rozdział trzeci jest poświęcony prezentacji metod szacowania bezrobocia równowagi. Przedstawiono też analizę dotychczasowych wyników oszacowań bezrobocia równowagi w wybranych krajach Europy Środkowo-Wschodniej.

Rozdział czwarty ma charakter empiryczny. Znajdują się w nim wyniki oszacowań bezrobocia równowagi dokonane przez polskich ekonomistów, a także własne wyniki oszacowań stóp bezrobocia równowagi (NAIRU) sformułowane w oparciu o metody przepływów oraz rozszerzoną krzywą Phillipsa.

W rozdziale piątym podjęto natomiast próbę odpowiedzi na pytanie, czy zmiany relacji między faktyczną stopą bezrobocia a stopą bezrobocia równowagi miały wpływ na stopień restrykcyjności polityki fiskalnej i polityki pieniężnej w Polsce. Analizy dotyczące wpływu relacji między faktyczną stopą bezrobocia a stopą bezrobocia równowagi na stopień restrykcyjności polityki pieniężnej i fiskalnej zostały poprzedzone prezentacjami metod pomiaru stopnia restrykcyjności tych polityk w Polsce.

Zakończenie zawiera wnioski z przeprowadzonych analiz.

Składam serdeczne podziękowania Panu Profesorowi Eugeniuszowi Kwiatkowskiemu, Panu Profesorowi Wacławowi Jarmołowiczowi oraz Pani Doktor Sylwii Roszkowskiej za komentarze, uwagi i sugestie, które przyczyniły się do powstania niniejszej książki w obecnym kształcie. 



\section{Rozdzial 1}

\section{Bezrobocie równowagi oraz jego determinanty - ujęcie teoretyczne}

Pojęcie naturalnej stopy bezrobocia ${ }^{1}$ zostało wprowadzone do literatury ekonomicznej po raz pierwszy przez M. Friedmana w 1968 r. Co prawda E. S. Phelps swoją teorię bezrobocia równowagi opublikował w 1967 r., jednak zamiast naturalnej stopy bezrobocia używał określeń: „optymalna ścieżka bezrobocia” lub „bezrobocie w stanie równowagi” (zob. Phelps 1967, s. 254-256; Godłów-Legiędź 2008, s. 4). Dlatego też niektórzy ekonomiści przypisują M. Friedmanowi autorstwo całej teorii naturalnej stopy bezrobocia. Takie podejście jest jednak krzywdzące dla E. S. Phelpsa, bowiem to jego teoria ma głębszą podbudowę teoretyczną.

Friedman w swoim artykule celowo użył określenia ,naturalna stopa bezrobocia". Chciał w ten sposób nawiązać do koncepcji naturalnej stopy procentowej Wicksella, która informuje, jaki dochód pieniężny przedsiębiorcy mają nadzieję osiągnąć (a nie osiągają) z zainwestowanych (pożyczonych) kapitałów (zob. James 1958, s. 72). Gdy rynkowa stopa procentowa jest równa naturalnej stopie procentowej, następuje stabilizacja procesów inflacyjnych w gospodarce. Natomiast gdy rynkowa stopa procentowa jest niższa od naturalnej stopy procentowej, następuje przyspieszenie procesów inflacyjnych. W przeciwnym razie w gospodarce nastąpi spadek ogólnego poziomu cen (zob. Michałek 2012, s. 164-165). Do tych rozważań Wicksella nawiązał w swej teorii Friedman.

Określenie „naturalna stopa bezrobocia” może sugerować, iż jest to normalna stopa bezrobocia, której nie można uniknąć czy też zmienić. Wysokość naturalnej stopy bezrobocia może się jednak zmieniać na skutek zmian strukturalnych zachodzących na rynku pracy oraz na innych rynkach (będzie o tym mowa dalej).

Celem tego rozdziału jest przedstawienie istoty bezrobocia równowagi, krytyczna analiza podstawowych teorii bezrobocia związanych $\mathrm{z}$ bezrobociem równowagi oraz przedstawienie determinantów bezrobocia równowagi.

${ }^{1}$ Pojęcia „naturalna stopa bezrobocia” oraz „,bezrobocie równowagi” są często używane zamiennie, chociaż właściwie nie są tożsame. Naturalna stopa bezrobocia jest określonym, friedmanowskim ujęciem bezrobocia równowagi. W teorii ekonomii wysunięto również inne ujęcia tego bezrobocia (będzie o nich mowa w dalszych rozważaniach). 


\subsection{Bezrobocie równowagi jako jeden $\mathrm{z}$ typów bezrobocia}

Bezrobocie jest zjawiskiem mającym wiele przyczyn, bardzo często wzajemnie ze sobą powiązanych. Do najważniejszych czynników mających wpływ na poziom bezrobocia należą: ekonomiczne, społeczne i demograficzne. $Z$ tych względów w literaturze ekonomicznej można znaleźć bardzo wiele klasyfikacji bezrobocia. I tak np. J. J. Hughes i R. Perlman (1984) wymieniają aż 70 różnego rodzaju typów bezrobocia. Do tradycyjnych typów zalicza się bezrobocie:

- frykcyjne,

- cykliczne (koniunkturalne),

- strukturalne,

- utajone (ukryte).

Klasyfikacja ta jest podstawą większości opracowań dotyczących bezrobocia (zob. Kwiatkowski 2002a, s. 46; Socha, Sztanderska 2000, s. 15). Przyjrzyjmy się tym typom bezrobocia ze względu na ich istotne znaczenie dla zrozumienia bezrobocia równowagi.

Interpretacja bezrobocia frykcyjnego nie budzi większych kontrowersji w literaturze ekonomicznej. W powszechnym przekonaniu ma ono charakter krótkotrwały. Jego występowanie jest spowodowane dynamicznymi zmianami zachodzącymi na rynku pracy w każdej gospodarce rynkowej. W gospodarce rynkowej mamy bowiem do czynienia z jednoczesnym tworzeniem i likwidacją miejsc pracy (w związku z likwidacją miejsc pracy niektórzy dotychczas pracujący stają się bezrobotnymi). Ponadto część osób pracujących, niezadowolonych z warunków płacowych, podejmuje starania, by znaleźć lepiej płatną pracę i decyduje się - dla ułatwienia poszukiwań - pozostać bezrobotnymi. Równocześnie część bezrobotnych i biernych zawodowo podejmuje próby znalezienia pracy. Należy pamiętać, że proces dopasowywania bezrobotnych do ofert pracy nie zachodzi natychmiast. Z uwagi na niedoskonały przepływ informacji o wolnych miejscach pracy oraz zróżnicowaną intensywność poszukiwań, część miejsc pracy pozostaje wolna, a jednocześnie pewna liczba bezrobotnych dalej pozostaje bez pracy. $\mathrm{W}$ ten sposób powstaje bezrobocie frykcyjne.

$\mathrm{Z}$ bezrobociem frykcyjnym mamy także do czynienia wówczas, gdy wolne miejsca pracy i bezrobotni występują w tych samych zawodach i w tym samym regionie (miejscu). Natomiast ilu bezrobotnych pozostanie bez pracy, pomimo istniejących ofert pracy, zależy od efektywności funkcjonowania urzędów pracy oraz intensywności poszukiwań. Bezrobocie frykcyjne jest mało wrażliwe na zmiany koniunktury gospodarczej. Jego poziom zależy od jakości usług pośrednictwa pracy, intensywności poszukiwań pracy, tempa tworzenia i likwidacji miejsc pracy oraz liczby osób wchodzących na rynek pracy. Nie jest możliwa całkowita likwidacja tego typu bezrobocia. 
Każda gospodarka rynkowa podlega wahaniom cyklicznym. Na poziom produkcji oddziałują różnego rodzaju szoki popytowe i podażowe ${ }^{2}$. Negatywne szoki popytowe przyczyniają się do spadku produkcji, spadku zatrudnienia i wzrostu bezrobocia. Bezrobocie spowodowane spadkiem agregatowego popytu jest określane mianem bezrobocia koniunkturalnego (cyklicznego). Według P. A. Samuelsona i W. D. Nordhausa przyczyną powstawania bezrobocia cyklicznego jest niski poziom agregatowego popytu przy nieelastycznych płacach i cenach (zob. Samuelson, Nordhaus 2012, s. 666).

Bezrobocie tego typu zmniejsza się wraz z poprawą koniunktury (spowodowaną wzrostem agregatowego popytu). Wzrost agregatowego popytu w okresie krótkim prowadzi bowiem do wzrostu produkcji w gospodarce. Z kolei wzrost produkcji przyczynia się do wzrostu popytu na pracę i spadku bezrobocia. Jednak $\mathrm{z}$ uwagi na występowanie zjawiska histerezy, poprawa koniunktury gospodarczej nie musi prowadzić do całkowitej likwidacji bezrobocia cyklicznego ${ }^{3}$.

Niektórzy ekonomiści upatrują przyczyn bezrobocia koniunkturalnego w ograniczeniach podażowych. Ich zdaniem w okresie recesji zasoby czynników produkcji z reguły się kurczą. Po zakończeniu kryzysu wzrost popytu na produkty nie musi prowadzić do spadku bezrobocia, jeśli zasoby czynników produkcji będą niedostateczne (zob. Hudson 1988, s. 53).

Uogólniając, przyczyną powstawania bezrobocia cyklicznego (koniunkturalnego) są okresowe wahania agregatowego popytu oraz aktywności gospodarczej lub ograniczenia podażowe (bariery zdolności wytwórczych). Jest ono często określane mianem bezrobocia keynesowskiego.

W literaturze ekonomicznej można znaleźć dwa ujęcia bezrobocia strukturalnego, a mianowicie w znaczeniu wąskim (tzw. bezrobocie strukturalne sensu stricto) oraz szerokim (tzw. bezrobocie strukturalne sensu largo; zob. Socha, Sztanderska 2000, s. 14). Warto przyjrzeć się im bliżej.

Struktura popytu na pracę w gospodarce rynkowej zmienia się w czasie. Przyczyną zmian jest ciągły rozwój technologii, zmiana struktury popytu na produkty oraz zmiany gustów konsumentów. Czynniki te powodują zmianę struktury

\footnotetext{
${ }^{2}$ Szoki (wstrząsy) gospodarcze to nagłe zdarzenia w gospodarce wpływające na podstawowe zmienne makroekonomiczne (np. produkcję, zatrudnienie, bezrobocie, inflację etc.). Można wyróżnić dwa rodzaje szoków - popytowe i podażowe. Szoki popytowe powstają na skutek nagłych zmian poziomu agregatowego popytu. W zależności od kierunku zmiany wielkości agregatowego popytu można wyróżnić pozytywne i negatywne szoki popytowe. W sytuacji wzrostu agregatowego popytu mamy do czynienia z pozytywnym szokiem popytowym. Spadek agregatowego popytu określa się mianem negatywnego szoku popytowego. Przykładem negatywnego szoku popytowego jest spadek agregatowego popytu spowodowany kryzysem zadłużenia w krajach strefy euro.

Szoki podażowe polegają na nagłych zmianach wielkości agregatowej podaży. Wyróżnia się pozytywne szoki podażowe (polegające na niespodziewanym wzroście agregatowej podaży) oraz negatywne szoki podażowe (polegające na nagłym zmniejszaniu się agregatowej podaży). Przykładem negatywnego szoku podażowego jest nagły spadek podaży artykułów rolnych spowodowany suszą.

${ }^{3}$ Teorie histerezy zostaną omówione w podrozdziale 1.7 .
} 
produkcji i struktury popytu na pracę. Podaż pracy nie dostosowuje się natychmiast do zmian struktury popytu na pracę, dlatego też pojawiają się niedopasowania między popytem na pracę a podażą pracy, czyli bezrobocie strukturalne w wąskim znaczeniu.

Bezrobocie strukturalne - w wąskim znaczeniu - powstaje w wyniku niedopasowań struktury podaży pracy do struktury popytu na pracę w przekroju kwalifikacyjnym, gałęziowym, poziomów wykształcenia oraz przestrzennym (w szczególności regionalnym). Ludzie pozostają bezrobotnymi pomimo zgłaszanej gotowości do pracy, ponieważ wolne miejsca pracy zgłaszane przez pracodawców nie odpowiadają ich kwalifikacjom. W każdej gospodarce utrzymuje się pewien poziom niedopasowań strukturalnych, ponieważ pracownicy nie są doskonale mobilni - zarówno w przekroju zawodowym, jak i geograficznym (zob. Sapsford 1981, s. 177). Przyczyn niedopasowań strukturalnych można zatem upatrywać w niskiej mobilności przestrzennej i niskiej mobilności funkcjonalnej (jest to zdolność dokonywania zmian struktury siły roboczej, czyli zmian posiadanych kwalifikacji i zawodu, nabywania nowych umiejętności i przyswajania zmian technologicznych) (zob. Pissarides 1997, s. 12). Bezrobocie strukturalne w omawianym znaczeniu obejmuje niedopasowania struktury podaży do popytu na siłę roboczą na poszczególnych mikrorynkach (zob. Jackman, Roper 1987, s. 10; Socha, Sztanderska 2000, s. 26).

W przypadku bezrobocia strukturalnego (w wąskim znaczeniu) mamy zatem do czynienia $\mathrm{z}$ trwałymi niedopasowaniami między strukturą podaży pracy i strukturą popytu na pracę. Trwałość niedopasowań wynika z wysokich kosztów mobilności siły roboczej. Zwłaszcza zmiana miejsca zamieszkania wiąże się z koniecznością poniesienia bardzo wysokich kosztów. Samego trwałego i wysokiego zróżnicowania stóp bezrobocia w niektórych przekrojach siły roboczej nie można jednak traktować jako przejawu bezrobocia strukturalnego (zob. Socha, Sztanderska 2000, s. 26). Dotyczy to zwłaszcza wieku i płci. Zróżnicowania stóp bezrobocia w tych dwóch przekrojach nie da się zmniejszyć poprzez zwiększenie mobilności siły roboczej.

Bezrobocie strukturalne w szerokim znaczeniu (bezrobocie strukturalne sensu largo) obejmuje z kolei bezrobocie frykcyjne, bezrobocie strukturalne w wąskim znaczeniu oraz bezrobocie instytucjonalne (zob. Kwiatkowski 2002a, s. 48-49). Prezentowana klasyfikacja bezrobocia nie jest klasyfikacją rozłączną. Bezrobocie strukturalne zarówno w wąskim, jak i szerokim znaczeniu jest mało wrażliwe na zmiany koniunktury gospodarczej.

Bezrobocie instytucjonalne wynika $\mathrm{z}$ istniejących przepisów, relacji oraz zachowań pracowników, pracodawców i bezrobotnych na rynku pracy (zob. Haltiwanger 1987, s. 610; Jarmołowicz, Woźniak 2005, s. 60). Przyczyną powstawania bezrobocia instytucjonalnego są instytucje rynku pracy, do których można zaliczyć: zasiłki dla bezrobotnych (ich wysokość, dostępność oraz okres pobierania) i z opieki społecznej, płace minimalne, układy zbiorowe pracy, pozapłacowe koszty pracy (klin podatkowy) oraz prawną ochronę zatrudnienia. Występujące 
przepisy i ograniczenia zmniejszają elastyczność rynku pracy, przyczyniając się do powstawania bezrobocia instytucjonalnego.

Wzrost hojności systemu zasiłkowego przyczynia się do zwiększania bezrobocia ${ }^{4}$. Osoby bezrobotne posiadające prawo do zasiłku nie są bowiem często zainteresowane poszukiwaniem pracy w okresie, w którym pobierają zasiłek. Z kolei pracodawcy, z uwagi na wysokie koszty przyjęć do pracy, wolą podpisywać z pracownikami długoterminowe kontrakty o pracę. W związku z tym bezrobotni, pomimo posiadania odpowiednich kwalifikacji, nie mogą podjąć pracy, ponieważ aktualnie zatrudnieni pracownicy dysponują wyższą siłą w negocjacjach z pracodawcami (teoria "swoich" i obcych). Dlatego też zbyt wysokie zasiłki oraz słaba pozycja „obcych” ograniczają podejmowanie pracy przez bezrobotnych i mogą się przyczynić do powstawania bezrobocia instytucjonalnego.

R. Layard, S. Nickell i R. Jackman (2005) definiują niedopasowania strukturalne jako różnicę między faktyczną (przeciętną) stopą bezrobocia w gospodarce a minimalną stopą bezrobocia, przy której ceny pozostają na stabilnym poziomie. Im wyższy jest poziom zróżnicowania bezrobocia w poszczególnych sektorach gospodarki, tym wyższy jest poziom bezrobocia strukturalnego ${ }^{5}$. Gdyby stopy bezrobocia w poszczególnych sektorach były równe przeciętnej stopie bezrobocia, to wówczas występujące bezrobocie miałoby charakter cykliczny (koniunkturalny).

Niedopasowania strukturalne (mismatch) prowadzą do wzrostu bezrobocia strukturalnego (czyli tej części, która nie zanika wraz ze wzrostem gospodarczym) poprzez tworzenie presji na wzrost płac (zob. Layard, Nickell, Jackman 2005, s. 313-324). Presja ta pojawia się w okresie spadku bezrobocia i utrzymywania się go na niskim poziomie. W okresie wzrostu bezrobocia presja na wzrost płac spowodowana niedopasowaniami strukturalnymi słabnie.

Bezrobocie utajone (ukryte) to typ bezrobocia nieujmowany w oficjalnych statystykach. Jest ono utożsamiane $\mathrm{z}$ przerostem zatrudnienia. $\mathrm{Z}$ bezrobociem ukrytym mamy do czynienia, gdy wzrost zatrudnienia nie powoduje wzrostu produkcji. Występowało ono w znacznej skali w gospodarkach nakazowo-rozdzielczych. Obecnie przejawem bezrobocia ukrytego w polskiej gospodarce jest nadzatrudnienie $w$ rolnictwie.

W polskiej literaturze przedmiotu wymienia się również bezrobocie transformacyjne jako odrębny typ bezrobocia. Przyczyną jego powstania była recesja

${ }^{4}$ Jak wskazują M. Socha i U. Sztanderska (2000), zasiłki dla bezrobotnych mogą teoretyczne przyczyniać się do ograniczania bezrobocia. Osoby pobierające zasiłek mogą dzięki temu dłużej poszukiwać pracy, co może wpłynąć pozytywnie na dopasowanie podaży pracy do popytu na pracę. Wydłużenie okresu poszukiwań może jednak spowodować, że dana jednostka stanie się bezrobotnym długookresowo, co tym samym znacząco zmniejszy jej szansę na znalezienie pracy (zob. Sztanderska, Socha 2000, s. 56).

${ }^{5}$ Sektory gospodarki są tutaj utożsamiane z sekcjami działalności gospodarczej. W Polskiej Klasyfikacji Działalności (PKD) obowiązującej od 1 stycznia 2008 r. wyróżniono 21 sekcji (zob. Polska Klasyfikacja Działalności, 2007, www.stat.gov.pl/klasyfikacje/pkd_07/pkd_07.htm). 
spowodowana transformacją systemu gospodarki nakazowo-rozdzielczej w gospodarkę rynkową oraz likwidacja nadmiernego zatrudnienia, które cechowało przedsiębiorstwa państwowe funkcjonujące w poprzednim systemie gospodarczym (zob. Socha, Sztanderska 2000, s. 69; Wrońska 2005, s. 26; Adamczyk 2006, s. 39-60). Bezrobocie transformacyjne było efektem systemowych przekształceń gospodarek nierynkowych (zob. Jarmołowicz 2013, s. 142-143).

Bezrobocie transformacyjne nie jest kategorią jednorodną. W jego skład wchodzi transformacyjne bezrobocie strukturalne oraz transformacyjne bezrobocie instytucjonalne.

Transformacyjne bezrobocie strukturalne jest bezpośrednim rezultatem transformacji gospodarczej. Jego rozmiary zależą od tempa racjonalizacji zatrudnienia w gospodarce, wysokości udziału dochodów i wydatków budżetowych w PKB oraz skali występowania ujemnego salda bilansu płatniczego. Ten typ bezrobocia jest mało wrażliwy na zmiany koniunktury gospodarczej oraz politykę makroekonomiczną państwa (zob. Balicki, Ptaszyńska 2003, s. 37-50).

$\mathrm{Z}$ kolei transformacyjne bezrobocie instytucjonalne, tak samo jak transformacyjne bezrobocie strukturalne, jest efektem przekształceń systemowych. W okresie transformacji systemowej istniały stare instytucje rynku pracy (które powstały przed okresem transformacji) i równocześnie powstawały nowe (często tworzone w pośpiechu) instytucje rynku pracy. Niespójność między tymi instytucjami przyczyniała się do wzrostu bezrobocia instytucjonalnego (zob. Jarmołowicz, Woźniak 2006, s. 55).

Według W. Jarmołowicza i B. Woźniak poziom transformacyjnego bezrobocia instytucjonalnego zależy od: siły przetargowej związków zawodowych, stopnia ochrony zatrudnienia, regulacji dotyczących płac minimalnych, sposobu opodatkowania pracy, systemu zasiłków dla bezrobotnych i pomocy socjalnej, występowania oraz wielkości szarej strefy (zob. Jarmołowicz, Woźniak 2006, s. 55). Należy jednak zwrócić uwagę, że te czynniki wpływają również na inne typy bezrobocia, stąd pomiar skali zjawiska transformacyjnego bezrobocia instytucjonalnego jest bardzo trudny.

Bardziej nowoczesną klasyfikacją bezrobocia jest jego podział na bezrobocie równowagi oraz bezrobocie nierównowagi (zob. Samuelson, Nordhaus 2012, s. 606-608 $)^{6}$. Bezrobocie nierównowagi to bezrobocie występujące w sytuacji

${ }^{6}$ Według P. A. Samuelsona i W. D. Nordhausa z bezrobociem równowagi mamy do czynienia, gdy ludzie dobrowolnie rezygnują z pracy w celu zmiany miejsca pracy lub przejścia do bierności zawodowej. Z kolei bezrobocie nierównowagi występuje, gdy rynek pracy (lub cała gospodarka) funkcjonuje wadliwie, a pracownicy gotowi do podjęcia pracy oraz dysponujący wysokimi kwalifikacjami nie mogą znaleźć zatrudnienia przy obowiązującym poziomie płac (zob. Samuelson, Nordhaus 2012, s. 606-607).

Natomiast według B. Woźniak (2008) bezrobocie równowagi to takie, które nie ulega likwidacji w warunkach wzrostu gospodarczego i występuje w punkcie równowagi gospodarczej (obejmuje ono bezrobocie o charakterze strukturalnym i instytucjonalnym). Bezrobocie 
nadwyżki podaży pracy nad popytem na pracę. Obejmuje ono bezrobocie koniunkturalne (cykliczne, keynesowskie) bądź (i według innych poglądów) bezrobocie dobrowolne (neoklasyczne) (zob. np. Samuelson, Nordhaus 2012, s. 260-261). Bezrobocie keynesowskie jest również określane mianem bezrobocia przymusowego. Do teorii rynku pracy, których przedmiotem zainteresowania jest bezrobocie nierównowagi, można zaliczyć: keynesowską teorię bezrobocia, teorię neoklasyczną, teorię „swoich" i „obcych”, teorię płacy motywującej oraz teorię niepisanych kontraktów płacowych.

Bezrobocie równowagi to bezrobocie występujące w warunkach równowagi na rynku pracy, czyli w punkcie zrównania się podaży pracy z popytem na pracę ${ }^{8}$. Jest ono mało wrażliwe na zmiany koniunktury gospodarczej. Poziom bezrobocia równowagi może być miarą sprawności funkcjonowania rynku pracy (zob. Jarmołowicz, Woźniak 2005, s. 55).

Bezrobocie strukturalne w szerokim znaczeniu jest często utożsamiane $\mathrm{z}$ bezrobociem równowagi. Można również przyjąć, że bezrobocie równowagi obejmuje bezrobocie frykcyjne i bezrobocie strukturalne w wąskim znaczeniu (zob. Socha, Sztanderska 2000, s. 15).

W literaturze ekonomicznej dominujące znaczenie mają dwa ujęcia równowagi (zob. Chick 1983, s. 21; Kwiatkowski 2009, s. 10). W pierwszym ujęciu równowagę definiuje się jako stan spoczynku gospodarki, co oznacza, że w gospodarce nie działają siły prowadzące do zmian lub te siły wzajemnie się równoważą. W drugim ujęciu równowaga jest wyjaśniana jako stan, w którym popyt zrównuje się z podażą.

Powstaje pytanie, $\mathrm{z}$ którym ujęciem równowagi mamy do czynienia w wysuwanych definicjach bezrobocia równowagi? Trzeba to pytanie rozważyć najpierw w świetle teorii naturalnej stopy bezrobocia, a następnie w świetle teorii NAIRU.

Zgodnie z definicją podaną przez M. Friedmana, naturalna stopa bezrobocia to ,taki poziom, który wynikałby z walrasowskiego układu równań równowagi ogólnej, pod warunkiem uwzględnienia w nim aktualnych cech strukturalnych rynków siły roboczej i dóbr, w tym ich niedoskonałości, stochastycznej zmienności popytu i podaży, kosztów zbierania informacji o wolnych miejscach pracy i o dostępności siły roboczej, kosztów mobilności itp." (zob. Friedman 1975, s. 271). Z definicji tej wynika, że naturalna stopa bezrobocia odpowiada obu ujęciom stanu równowagi. Należy również podkreślić, że jest to poziom bezrobocia w stanie równowagi na niedoskonałych rynkach, w tym również na rynku pracy.

nierównowagi definiowane jest zaś jako „reszta” bezrobocia. Równowaga gospodarcza według różnych podejść oznacza: równowagę popytu i podaży pracy; równowagę oczekiwanych i faktycznych płac oraz cen; równowagę liczby bezrobotnych i wolnych miejsc pracy, etc. (zob. Woźniak 2008, s. 6, 10-11).

${ }^{7}$ W pracy używane jest zamiennie określenie - teoria „insiders - outsiders”.

${ }^{8}$ P. A. Samuelson i W. D. Nordhaus (2012) definiują bezrobocie równowagi jako stopę bezrobocia występującą przy ustabilizowanej inflacji (zob. Samuelson, Nordhaus 2012, s. 666). 
Potwierdzeniem tezy o tym, że naturalna stopa bezrobocia to wielkość odpowiadająca równowadze między popytem i podażą na wszystkich rynkach, jak również równowadze w stanie spoczynku gospodarki jest twierdzenie obu autorów koncepcji naturalnej stopy bezrobocia, że w gospodarce rynkowej działają mechanizmy sprowadzające bezrobocie faktyczne do poziomu bezrobocia naturalnego (zob. Kwiatkowski 2009, s. 14)9. Swoje stanowisko uzasadniają oni występowaniem zjawiska iluzji pieniężnej wśród podmiotów gospodarczych oraz adaptacyjnymi oczekiwaniami inflacyjnymi. Friedman i Phelps nie traktują naturalnej stopy bezrobocia jako wielkości niezmiennej w czasie, a zatem stan spoczynku gospodarki nie jest dla nich stanem permanentnym. Naturalna stopa bezrobocia może się zmieniać pod wpływem czynników realnych, o których będzie mowa w dalszej części tego rozdziału.

Uogólniając, można powiedzieć, że naturalna stopa bezrobocia stanowi nieunikniony poziom bezrobocia (frykcyjnego i strukturalnego) w gospodarce funkcjonującej w warunkach konkurencji niedoskonałej, a więc zbliżenie gospodarki w kierunku gospodarki doskonałej powinno prowadzić do obniżenia naturalnej stopy bezrobocia. $Z$ definicji naturalnej stopy bezrobocia można również wysnuć wniosek, że w warunkach konkurencji doskonałej naturalna stopa bezrobocia byłaby równa zero.

Koncepcja naturalnej stopy bezrobocia powstała w ramach szeroko rozumianego nurtu neoklasycznego. Idea bezrobocia równowagi została również podjęta przez przedstawicieli ekonomii keynesistowskiej. W latach 80. XX w. R. Layard, S. Nickell oraz R. Jackman, wysunęli teorię NAIRU (Non Accelerating Inflation Rate of Unemployment). Głównym przedmiotem jej zainteresowań jest bezrobocie równowagi. Teoria NAIRU nawiązuje do związku między inflacją i bezrobociem. Według twórców tej koncepcji, jeśli bezrobocie utrzymuje się na niskim poziomie, to nasilają się procesy inflacyjne, natomiast przy wysokim poziomie bezrobocia procesy inflacyjne ulegają osłabieniu. Wysuwają oni stąd wniosek, że istnieje taki poziom bezrobocia, który stabilizuje procesy inflacyjne w gospodarce (zob. Jackman, Nickell, Layard 1991, s. 15). Ten poziom bezrobocia określają jako NAIRU i traktują jako bezrobocie równowagi. W literaturze znaleźć można różne interpretacje NAIRU. Według jednej z nich NAIRU to stopa bezrobocia, przy której inflacja jest stabilna. Niektórzy ekonomiści definiują NAIRU jako poziom bezrobocia, który stabilizuje relatywną siłę związków zawodowych i pracodawców w negocjacjach płacowych (zob. Robinson 1986, s. 343).

\footnotetext{
${ }^{9}$ Tylko w krótkim okresie faktyczna stopa bezrobocia może odchylać się od naturalnej stopy bezrobocia z powodu występowania zjawiska iluzji pieniężnej. W okresie długim pracownicy i przedsiębiorcy potrafią rozróżniać wielkości realne i nominalne. W odpowiedzi na żądania podwyżek płac pracodawcy obniżą zatrudnienie. Spadek zatrudnienia spowoduje wzrost bezrobocia. Bezrobocie będzie rosło aż do osiągnięcia poziomu naturalnej stopy bezrobocia.
} 
Możemy wyróżnić krótko- i długookresową stopę bezrobocia NAIRU. NAIRU krótkookresowa to stopa, która występuje w momencie stabilizowania inflacji na jej poziomie w danym okresie (kwartału czy też roku). NAIRU długookresowa jest to stopa bezrobocia (w warunkach steady state) występująca po dostosowaniu się gospodarki do wszystkich szoków podażowych oraz długookresowych efektów polityki pieniężnej (zob. Socha, Wojciechowski 2004, s. 8).

Niektórzy ekonomiści, np. P. Minford, L. Ball oraz N. G. Mankiw, traktują NAIRU i naturalną stopę bezrobocia jako synonimy (zob. Snowdon, Vane, Wynarczyk 1998, s. 246; Ball, Mankiw 2002, s. 1). Należy zwrócić uwagę, iż w teorii naturalnej stopy bezrobocia przyjmuje się założenie, że rynek pracy znajduje się $\mathrm{w}$ stanie równowagi, natomiast $\mathrm{w}$ teorii NAIRU nie przyjmuje się tego założenia. Z powyższych rozważań można wysnuć wniosek, że NAIRU to stopa bezrobocia równowagi w stanie spoczynku gospodarki (zob. Kwiatkowski 2009, s. 14). Szczegółowe zestawienie podobieństw i różnic między NAIRU i naturalną stopą bezrobocia można znaleźć w opracowaniu W. Jarmołowicza i B. Woźniak (zob. Jarmołowicz, Woźniak 2005, s. 62).

Ważnym kryterium podziału bezrobocia, z punktu widzenia celu głównego niniejszej pracy, jest czas jego trwania. Według tego kryterium można wyróżnić (zob. Unolt 1999, s. 43) bezrobocie:

- krótkookresowe (do 6 miesięcy),

- średniookresowe (od 7-12 miesięcy),

- długookresowe (powyżej 12 miesięcy).

Bezrobotni długookresowo z uwagi na ubytek kapitału ludzkiego mają mniejsze szanse znalezienia pracy w porównaniu do bezrobotnych krócej przebywających w zasobie bezrobocia. Wzrost liczby bezrobotnych dhugookresowo prowadzi zatem do wzrostu poziomu bezrobocia równowagi.

\subsection{Teoria naturalnej stopy bezrobocia}

Koncepcja krótkookresowej krzywej Phillipsa, która była podstawą polityki gospodarczej w latach 60. XX w., stała się pod koniec lat 60. przedmiotem ożywionej krytyki (zob. Blaug 1994, s. 682-683). Powodem tego stanu był znaczny wzrost w wielu krajach rozwiniętych indeksów stagflacji, czyli sumy stóp inflacji i bezrobocia (zob. Kwiatkowski 2002a, s. 143). Wzrost łącznego popytu przyczyniał się do wzrostu poziomu cen, nie powodował jednak obniżenia bezrobocia.

Próba wyjaśnienia tych kwestii została podjęta w ramach prowadzonych niezależnie od siebie badań przez M. Friedmana (1968) i E. S. Phelpsa (1967). Jak już wspomniano w podrozdziale 1.1, Friedman jako pierwszy użył pojęcia ,naturalna stopa bezrobocia", dlatego to jemu zazwyczaj przypisuje się autorstwo całej koncepcji naturalnej stopy bezrobocia. 
O ile koncepcja Phelpsa ma charakter wysoce sformalizowany, to koncepcja bezrobocia równowagi zaproponowana przez Friedmana ma charakter opisowy. Cechą wspólną obu koncepcji są podobne założenia przyjmowane w tych modelach. Zakładają oni, że (zob. Friedman 1968, s. 8; Phelps 1970, s. 131-134):

- na rynku pracy jest wielu pracowników i pracodawców, w związku z tym żaden z pracowników nie może wpływać na poziom płac rynkowych, natomiast żaden z pracodawców nie może wpływać na poziom cen rynkowych;

- nie występuje doskonała przejrzystość rynku;

- pracownicy ponoszą koszty pozyskania informacji o wolnych miejscach pracy, a pracodawcy o dostępnej sile roboczej;

- występują koszty mobilności siły roboczej;

- występują stochastyczne zakłócenia po stronie popytu i podaży;

- pracownicy i pracodawcy formułują swoje przewidywania odnośnie kształtowania się płac i cen produktów na podstawie zbioru informacji z przeszłości, czyli mają oczekiwania adaptacyjne.

Należy też zwrócić uwagę na istotną różnicę między obydwoma koncepcjami. M. Friedman w odróżnieniu od E. S. Phelpsa zakłada, że ceny są giętkie i prowadzą do samooczyszczania się rynków (zob. Godłów-Legiędź 2008, s. 5).

\subsubsection{Koncepcja E. S. Phelpsa}

Phelps po raz pierwszy opublikował swoją koncepcję naturalnej stopy bezrobocia ${ }^{10}$ w 1967 r. (zob. Phelps 1967, s. 255-281). W roku następnym rozwinął ją w modelu poszukiwań. W tym podrozdziale zostanie przedstawiona wersja teorii naturalnej stopy bezrobocia Phelpsa opublikowana w 1970 r., która stanowi uzupełnienie jego artykułu z 1967 r. (zob. Bludnik 2010, s. 48).

Na początku swoich rozważań Phelps rozwija teorię nadwyżkowego popytu. Nadwyżkowy popyt na pracę, czyli nadwyżkę wolnych miejsc pracy nad liczbą bezrobotnych, można opisać wzorem:

$$
Y=V-U
$$

gdzie:

$Y$ - nadwyżkowy popyt na pracę,

$V$ - liczba wolnych miejsc pracy,

$U$ - liczba bezrobotnych.

Zgodnie z tą teorią, stopa zmian płac nominalnych jest proporcjonalna do stopy nadwyżki popytu (y). Stopa nadwyżki popytu jest definiowana jako relacja

${ }^{10}$ Phelps używa określeń: stopa bezrobocia w równowadze, stopa bezrobocia w warunkach stanu stacjonarnego (zob. Phelps 1970, s. 158-161). 
nadwyżki popytu nad podażą pracy do wielkości podaży pracy, czyli $y=Y / S$ (gdzie $S$ - podaż pracy). Stopę wolnych miejsc pracy $(v)$ można zdefiniować jako stosunek liczby wolnych miejsc pracy do wielkości podaży pracy $(v=V / S)$, zaś stopa bezrobocia to stosunek liczby bezrobotnych do wielkości podaży pracy $(u=U / S)$. A zatem stopa nadwyżkowego popytu na pracę to różnica między stopą wolnych miejsc pracy i stopą bezrobocia, czyli:

$$
y=v-u
$$

Według Phelpsa zależność między zmianami płac a stopą bezrobocia zobrazowana przy pomocy standardowej krótkookresowej krzywej Phillipsa została oparta na błędnym założeniu. W koncepcji tej przyjęto bowiem, że stopa nadwyżkowego popytu, która ma duży wpływ na zmiany płac, może być zastąpiona przez stopę bezrobocia. Zdaniem Phelpsa stopa bezrobocia nie jest dobrą aproksymantą stopy nadwyżkowego popytu na pracę (zob. Phelps 1970, s. 134). Phelps chwali Lipseya za jego błyskotliwe wyznaczenie z modelu dynamiki zatrudnienia relacji między stopą wolnych miejsc pracy (czyli stopą nadwyżkowego popytu na pracę) i stabilną stopą bezrobocia. Jednak jego zdaniem, w warunkach stanu niestabilnego, stopa bezrobocia nie odzwierciedla stopy nadwyżkowego popytu. W takiej sytuacji stopa zmian zatrudnienia jest dodatkową zmienną pozwalającą na wyznaczenie stopy nadwyżkowego popytu. W modelu zaproponowanym przez Phelpsa występują zatem dwie zmienne objaśniające. Stopa bezrobocia oraz stopa zmian zatrudnienia na jednostkę podaży pracy zastępują stopę wolnych miejsc pracy. Nadwyżkowy popyt, według Phelpsa, jest zatem funkcją stopy bezrobocia i stopy zmian zatrudnienia. Zależność ta pozwala na wyznaczenie krzywej Phillipsa wspartej oczekiwaniami oraz stabilną krzywą Phillipsa, opisującą zależność między stopą wzrostu płac a stabilną stopą bezrobocia.

Phelps przeprowadza swoją analizę w dwóch etapach. W pierwszym przyjmuje statyczne oczekiwania przedsiębiorstw i pracowników odnośnie kształtowania się cen i przyszłych stóp płac (czyli pracownicy i przedsiębiorstwa oczekują, że ceny i przeciętne stopy wzrostu płac nie będą różne od ich obecnych poziomów lub poziomów z najbliższej przyszłości). W drugim etapie Phelps wprowadza oczekiwania adaptacyjne odnośnie kształtowania się płac. Zakłada on, że oczekiwana stopa zmian poziomu płac jest różna od zera i dostosowuje się do przewidywanych przyszłych stóp zmian, czyli wprowadza do analizy oczekiwania adaptacyjne.

Phelps na wstępie swojej analizy zakłada, że każda z firm zmienia swoją stopę płac raz w ciągu roku. Przyjmuje on, że stała liczba firm o podobnym, średnim rozmiarze ustala stopy płac każdego dnia w ciągu roku. Oznacza to, że płaca przeciętna zmienia się w sposób łagodny pomimo zmian determinant optymalnej płacy w każdej firmie. Phelps przyjmuje zatem założenie, że oczekiwana stopa zmian płac wynosi 0 . 
Optymalne wynagrodzenie wypłacane przez $i$-tą firmę ${ }^{11}$ wyrażone w kategoriach pożądanej proporcjonalnej różnicy $\Delta_{i}^{*}$, między płacą danej firmy a średnią oczekiwaną płacą nominalną, jaka będzie płacona przez inne firmy w przeciągu pół roku, można opisać wzorem:

$$
\Delta_{i}^{*} \equiv \frac{w_{i}^{*}-w^{e}}{w^{e}}
$$

gdzie:

$\Delta_{i}^{*}$ - różnica między płacą w danej firmie a średnią oczekiwaną płacą nominalną,

$w_{i}^{*}$ - optymalna płaca w firmie $i$,

$w^{e}$ - przeciętna płaca oczekiwana w przeciągu pół roku zarówno przez firmę, jak i jej pracowników.

Phelps zakłada, że pracownicy i pozostałe firmy w branży mają średnio takie same oczekiwania odnośnie kształtowania się przyszłego poziomu płac (równe ich średniej oszacowanej płacy pół roku temu).

Zgodnie z założeniami przyjętymi w omawianej koncepcji, względna różnica płacowa $\Delta_{i}^{*}$ zależy od stopy bezrobocia $(u)$, zagregowanej stopy wolnych miejsc pracy $(v)$, liczby wolnych miejsc pracy w $i$-tej firmie $\left(V_{i}\right)$ oraz podaży pracy $(S)$. Zależność tę można opisać wzorem:

$$
\Delta_{i}^{*} \equiv j^{i}\left(u, v, V_{i}, S\right)
$$

Po podstawieniu: $v_{i}=\frac{V_{i}}{S}$ równanie (1.4) przyjmie postać:

$$
\Delta_{i}^{*} \equiv j^{i}\left(u, v, v_{i}\right)
$$

gdzie:

$v_{i}$ - stopa wolnych miejsc pracy w firmie $i$.

Niech: $j_{1}^{i}=\frac{\partial \Delta_{i}^{*}}{\partial u} \quad$ oraz $\quad j_{2}^{i}=\frac{\partial \Delta_{i}^{*}}{\partial v} \quad$ oraz $\quad j_{3}^{i}=\frac{\partial \Delta_{i}^{*}}{\partial v_{i}}$

$Z$ równania (1.4a) można wyciągnąć następujące wnioski:

- wraz ze wzrostem stopy bezrobocia optymalna płaca $\mathrm{w} i$-tej firmie maleje, a zatem maleje również względna różnica płacowa, czyli: $j_{1}^{i}<0$;

- jeśli rośnie stopa wolnych miejsc pracy $(v)$, to spodziewać się można wzrostu optymalnej płacy w danej firmie, a zatem $j_{2}^{i}>0$;

- wzrost stopy wolnych miejsc pracy w $i$-tej firmie prowadzi do wzrostu optymalnej płacy w tej firmie, a zatem: $j_{3}^{i}>0$.

${ }^{11}$ Optymalna płaca oznacza tutaj poziom wynagrodzeń, przy którym firma maksymalizuje zysk całkowity. 
W sytuacji gdy wszystkie firmy są takie same, względna różnica płacowa $\Delta^{*}$ dla każdej z firm jest taka sama i zależy od stopy bezrobocia i zagregowanej stopy wolnych miejsc pracy ${ }^{12}$ :

$$
\Delta^{*} \equiv g(u, v)
$$

Przyjęte założenia odnośnie znaków pierwszych i drugich pochodnych równania (1.5) pozwalają na wykreślenie rozszerzonej, ujemnie nachylonej i wypukłej krzywej Phillipsa.

Jeśli płaca przeciętna w każdej firmie jest zmienną ciągłą i różniczkowalną, to stopę zmian przeciętnych można opisać wzorem:

$$
\frac{\dot{w}}{w}=\lambda^{*}, \quad \lambda=\text { const. }, \quad \dot{w}=\frac{d w}{d t}
$$

$\mathrm{Z}$ równania (1.6) wynika, że jeśli $\Delta^{*}=0$, to $\dot{w}=0$, czyli płace są stałe. Jeśli oczekiwana stawka płac $\left(w^{e}\right)$ nie zmienia się od momentu ostatniej decyzji firmy odnośnie zmiany stopy płac i wzrasta jednocześnie $\Delta^{*}$, to wówczas rośnie stopa płac przeciętnych. Można się zatem spodziewać wzrostu przeciętnej płacy wraz z decyzjami kolejnych firm o podnoszeniu ich stóp płac przeciętnych. Przy założeniu statycznych oczekiwań nie jest możliwa ekstrapolacja obowiązującego wzrostu płac. Można więc przyjąć, że istnieje asymptotyczna stopa wzrostu płac odpowiadająca każdej dodatniej wartości $\Delta^{*}$.

W drugim etapie swoich rozważań Phelps przyjmuje założenie, że płace ustalane są w sposób ciągły. Utrzymane zostało założenie o statycznych oczekiwaniach odnośnie kształtowania się w przyszłości zmian płac przeciętnych. Przyjmuje się ponadto założenie, że oczekiwania odnośnie kształtowania się bieżącego poziomu płac przeciętnych $w^{e}$ (formułowane przez każdą z firm) zależą od wartości płacy przeciętnej z przeszłości w sposób adaptacyjny. Aby złagodzić zmiany płac, przyjmuje się, że oczekiwana różnica płacowa $\Delta_{i}^{e}$ zmierza stopniowo w kierunku pożądanej różnicy płacowej $\Delta_{i}^{*}$ :

$$
\frac{d \Delta_{i}^{e}}{d t}=\mu\left(\Delta_{i}^{*}-\Delta_{i}^{e}\right) \quad \mu>0
$$

oraz

$$
\begin{aligned}
& { }^{12} \text { Przyjmuje się, że dla } u>0 \text { oraz } v>0: \quad g_{1}=\frac{\partial \Delta^{*}}{\partial u}<0 \text { i } g_{2}=\frac{\partial \Delta^{*}}{\partial \mathrm{v}}>0 \\
& \text { oraz } g_{11}=\frac{\partial^{2} \Delta^{*}}{\partial u^{2}} \geq 0 \quad \text { i } g_{22}=\frac{\partial^{2} \Delta^{*}}{\partial v^{2}} \geq 0 \quad \text { i } \quad g_{12}=\frac{\partial g_{1}}{\partial v} \leq 0 .
\end{aligned}
$$




$$
\Delta_{i}^{e}=\frac{w_{i}-w^{e}}{w^{e}}
$$

gdzie:

$\Delta_{i}^{e}-$ oczekiwana różnica płacowa w $i$-tej firmie,

$w_{i}$ - płaca przeciętna $\mathrm{w} i$-tej firmie,

$w^{e}$ - oczekiwana płaca przeciętna.

Różniczkując równanie (1.6) względem czasu, otrzymujemy:

$$
\frac{d w^{e}}{d t}=\lambda\left(w-w^{e}\right)
$$

Z kolei wyznaczając pochodną równania (1.7a) względem czasu, otrzymujemy:

$$
\frac{d \Delta_{i}^{e}}{d t}=\frac{\frac{d w_{i}}{d t} w^{e}-w_{i} \frac{d w^{e}}{d t}}{\left(w^{e}\right)^{2}}
$$

Po przekształceniu równanie (1.7a) przyjmuje postać:

$$
w_{i}=w^{e}\left(\Delta_{i}^{e}+1\right)
$$

Różniczkując równanie (1.10) względem czasu, otrzymujemy:

$$
\frac{d w_{i}}{d t}=\frac{d w^{e}}{d t}\left(\Delta_{i}^{e}+1\right)+w^{e} \frac{d \Delta_{i}^{e}}{d t}
$$

Podstawiając równanie (1.7) do równania (1.11), uzyskujemy:

$$
\frac{d w_{i}}{d t}=\frac{d w^{e}}{d t}\left(\Delta_{i}^{e}+1\right)+w^{e} \mu\left(\Delta_{i}^{*}-\Delta_{i}^{e}\right)
$$

Przekształcając równania (1.10) i (1.12), otrzymujemy:

$$
\frac{1}{w_{i}} \frac{d w_{i}}{d t}=\frac{1}{w^{e}} \frac{d w^{e}}{d t}+\mu \frac{\Delta_{i}^{*}-\Delta_{i}^{e}}{\Delta_{i}^{e}+1}
$$

Po przekształceniach równania (1.8) otrzymujemy:

$$
\frac{1}{w^{e}} \frac{d w^{e}}{d t}=\lambda \Delta^{e}
$$

gdzie:
$\Delta^{e}-$ oczekiwana różnica płacowa $\mathrm{w}$ dowolnej firmie oraz: $\Delta^{e} \equiv \frac{w-w^{e}}{w^{e}}$.

Podstawiając równanie (1.14) do równania (1.13), otrzymujemy:

$$
\frac{1}{w} \frac{d w}{d t}=\lambda \Delta^{e}+\mu \frac{\Delta^{*}-\Delta^{e}}{\Delta^{e}+1}
$$


$\mathrm{Z}$ równania (1.10) wynika, że:

$$
\frac{w}{w^{e}}=\Delta^{e}+1
$$

Różniczkując równanie (1.16) obustronnie względem czasu, mamy:

$$
\frac{d\left(\frac{w}{w^{e}}\right)}{d t}=\frac{d \Delta^{e}}{d t}
$$

Po podzieleniu stronami równania (1.16a) i (1.16) otrzymujemy:

$$
\frac{\frac{d\left(\frac{w}{w^{e}}\right)}{d t}}{\frac{w}{w^{e}}}=\frac{\frac{d \Delta^{e}}{d t}}{\Delta^{e}+1}
$$

Podstawiając równanie (1.7) (pomijamy indeks $i$ ) do równania (1.16b), otrzymujemy równanie (1.17) następującej postaci:

$$
\frac{d\left(\frac{w}{w^{e}}\right)}{\frac{d t}{w^{e}}}=\frac{\mu\left(\Delta^{*}-\Delta^{e}\right)}{\Delta^{e}+1}
$$

Po dalszych przekształceniach równania (1.17) (z uwzględnieniem wartości wyznaczonych w równaniu (1.15)) otrzymano równanie:

$$
\frac{\frac{d\left(\frac{w}{w^{e}}\right)}{d t}}{\frac{w}{w^{e}}}=\frac{1}{w} \frac{d w}{d t}-\lambda \Delta^{e}
$$

Po podstawieniu równania (1.14) do równania (1.18) mamy:

$$
\frac{d\left(\frac{w}{w^{e}}\right)}{\frac{d t}{w^{e}}}=\frac{1}{w} \frac{d w}{d t}-\frac{1}{w^{e}} \frac{d w^{e}}{d t}
$$


Efektem przekształceń równań (1.19) i (1.13) (pomijamy indeksowania ze względu na to, że szukamy rozwiązania dla dowolnej firmy) jest równanie (1.20):

$$
\frac{\frac{d\left(\frac{w}{w^{e}}\right)}{d t}}{\frac{w}{w^{e}}}=\mu \frac{\Delta^{*}-\Delta^{e}}{\Delta^{e}+1}
$$

W rezultacie kolejnych przekształceń otrzymujemy ostatecznie:

$$
\frac{d\left(\frac{w}{w^{e}}\right)}{\frac{d t}{w}}=\mu\left(\frac{\Delta^{*}+1}{\frac{w}{w^{e}}}-1\right)
$$

$Z$ równania (1.21) wynika, że jeśli $\left(w / w^{e}\right)$ będzie dążyć do $\left(\Delta^{*}+1\right)$, to wartość całego wyrażenia będzie dążyć do 0 . W warunkach stanu stacjonarnego $\Delta^{e}$ jest stała, a zatem stopa zmian płac przeciętnych będzie równa oczekiwanej stopie zmian płac przeciętnych (tzn. $\Delta^{e}=\Delta^{*}$ ). W warunkach stanu stacjonarnego wzrosty płac są więc czystymi ich wyrównaniami do poziomu wartości oczekiwanej.

Równanie (1.21) w warunkach stanu stacjonarnego można zapisać w następujący sposób:

$$
\frac{\left(\frac{\overline{d w}}{d t}\right)}{w}=\lambda \Delta^{e}=\lambda \Delta^{*}
$$

Równanie (1.22) odpowiada każdej wartości $g(\bar{u}, \bar{v})$ w warunkach stanu stacjonarnego. Poza stanem stacjonarnym $\lambda \Delta^{*}$ może być dobrą miarą tempa zmiany płac. Jeśli $\mu=\lambda$ to stopa zmian płac, zmienia się nieznacznie wraz ze zmianą $\Delta^{e}$ (dla niewielkich wartości $\left.\Delta^{e}\right)$. Należy zwrócić uwagę, że bezpośredni wpływ wzrostu $\Delta^{*}$ na tempo wzrostu płac, przy danym $\Delta^{e}$, wygasa. Jednakże w rezultacie wzrostu $\Delta^{e}$ nastąpi wzrost wyrównań płacowych kosztem oddziaływań bezpośrednich.

Równania (1.5)-(1.6) opisują ogólną teorię nadwyżkowego popytu zmian stóp płac, kiedy oczekiwana stopa zmian płac wynosi 0 . Gdy $g(u, v)=u-v$, otrzymujemy równanie zmiany stóp płac następującej postaci:

$$
\frac{\left(\frac{d w}{d t}\right)}{w}=\lambda y
$$


Równanie (1.23) opisuje prostą teorię nadwyżkowego popytu, ale zdaniem Phelpsa to nie jest koniec analizy. Ponieważ zmienne $u$ i $v$ nie są zmiennymi niezależnymi od siebie, to konieczna jest analiza wpływu $v$ na ścieżkę zmian stopy bezrobocia $(u)$.

Na kolejnym etapie analizy Phelps łączy wyprowadzony model nadwyżkowego popytu $z$ teorią dynamiki zatrudnienia.

Przyjmijmy, że tempo wzrostu liczby pracujących w czasie wynosi: $\dot{L} \equiv \frac{d L}{d t}$. Całkowitą stopę zmian liczby pracujących na jednostkę podaży pracy $h$ można więc opisać wzorem:

$$
h=N(u, v, l)-\sigma(1-u)-Q(u, v, l)=h(u, v)
$$

gdzie: $u, v>0$ oraz: $h_{1}=\frac{\partial h}{\partial u}>0, h_{2}=\frac{\partial h}{\partial v}>0, h \equiv \frac{\dot{L}}{S}$

$N$ - liczba osób przyjętych do pracy,

$\sigma$-współczynnik odejść z pracy (z powodu śmierci lub przejścia na emeryturę; $\sigma \in(0,1))$,

$Q$ - liczba osób, które zdecydowały się na pozostanie bezrobotnymi w celu poszukiwania nowego miejsca pracy,

$h_{1}, h_{2}$ - pochodne cząstkowe funkcji $h$ względem $u$ oraz $v$.

$\mathrm{W}$ równaniu (1.24) zostały pominięte przymusowe przejścia na emerytury i zwolnienia z pracy (czyli przymusowe przejścia z zatrudnienia do bezrobocia). $\mathrm{W}$ tym równaniu uwzględnia się tylko bezrobotnych, którzy zrezygnowali z pracy w celu poszukiwania lepszych ofert. Jest to zatem bezrobocie dobrowolne.

Ponadto przyjmuje się założenie, że funkcje $Q$ i $N$ są jednorodne pierwszego stopnia. Phelps zakłada, że obie pochodne cząstkowe $\left(h_{1}\right.$ i $\left.h_{2}\right)$ są dodatnio określone. $Z$ przyjętych założeń wynika zatem, że im wyższa stopa wolnych miejsc pracy $(v)$, tym wyższa stopa zmian liczby pracujących $(h)$. Wzrost zasobu wolnych miejsc pracy zmusza bowiem firmy do zwiększenia intensywności poszukiwań nowych pracowników. Również wzrost stopy bezrobocia będzie prowadził do wzrostu stopy zmian liczby pracujących $(h)$. Rekrutacja nowych pracowników jest tym bardziej skuteczna, im wyższy jest poziom bezrobocia. Przy bezrobociu równym 0 rekrutacja nowych pracowników jest nieskuteczna.

Łącząc równania (1.5), (1.6) i (1.24), otrzymujemy krzywą Phillipsa wspartą oczekiwaniami jako funkcję $u$ i $v$ :

$$
\left\{\begin{array}{l}
\Delta^{*} \equiv g(u, v) \\
\frac{\dot{w}}{w}=\lambda \Delta^{*} \\
h(u, v)=N(u, v, l)-\sigma(1-u)-Q(u, v, l)=h(u, v)
\end{array}\right.
$$


Zmienną $h$ można potraktować jako zmienną niezależną, a zatem z trzeciego równania układu równań (1.25) zmienną $v$ można wyznaczyć jako funkcję zmiennych $h$ i $u$ :

$$
v=\Psi(u, h)
$$

A zatem z pierwszych dwóch równań z układu równań (1.25) otrzymujemy:

$$
\frac{\dot{w}}{w}=\lambda g(u, \Psi(u, h))=f(u, h)
$$

Równanie (1.27) opisuje krzywą Phillipsa wspartą oczekiwaniami adaptacyjnymi ${ }^{13}$. Aby określić kierunek zależności między poziomem $v$ a poziomem $u$ i $h$, musimy wyznaczyć pochodne cząstkowe równania (1.26) przy warunku: $h(u, \Psi(u, h))-h=0$ :

$$
\begin{gathered}
\Psi_{1}=\frac{\partial v}{\partial u}=-\frac{\frac{\partial h}{\partial u}}{\frac{\partial h}{v}}=-\frac{h_{1}}{h_{2}} \\
\Psi_{2}=\frac{\partial v}{\partial h}=\frac{1}{\left.\frac{\partial h}{\partial v}\right|_{v=\Psi(u, h)}}=\frac{1}{h_{2}}
\end{gathered}
$$

A zatem:

$$
\Psi_{1}(u, h)=-\frac{h_{1}(u, \Psi(u, h))}{h_{2}(u, \Psi(u, h))}=\frac{\partial \Psi}{\partial u}\langle 0
$$

Ujemny znak pochodnej $\Psi_{1}(u, h)$ wynika z założeń o wartości pochodnych $h_{1}$ i $h_{2}$, natomiast z uwagi na dodatnią wartość $h_{2}$ :

$$
\Psi_{2}(u, h)=\frac{1}{h_{2}(u, \Psi(u, h))}>0
$$

gdzie:

$\Psi_{1}(u, h)$ - pierwsza pochodna funkcji $\Psi$ względem $u$, $\Psi_{2}(u, h)$ - pierwsza pochodna funkcji $\Psi$ względem $h$.

${ }^{13} \mathrm{~W}$ późniejszym opracowaniu E. S. Phelps prezentuje następującą wersję krzywej Phillipsa wspartej oczekiwaniami (zob. Phelps 1995, s. 17):

$$
p=f(u)+p^{e}
$$

gdzie: $p$ - poziom cen, $p^{e}$ - oczekiwany poziom cen, $u$ - stopa bezrobocia. 
Drugie pochodne oraz pochodna mieszana równania (1.26) względem $u$ oraz $v$ wynoszą odpowiednio:

$$
\begin{gathered}
\Psi_{11}=\frac{\partial^{2} v}{\partial u^{2}}=\frac{\partial\left(-\frac{h_{1}}{h_{2}}\right)}{\partial u}=-\frac{\frac{\partial h_{1}}{\partial u} h_{2}-h_{1} \frac{\partial h_{2}}{\partial u}}{\left(h_{2}\right)^{2}}= \\
=-\frac{h_{11}+h_{12} \Psi_{1}+\Psi_{1} h_{21}+h_{22}\left(\Psi_{1}\right)^{2}}{\left(h_{2}\right)^{3}}>0 \\
\Psi_{22}=\frac{\partial^{2} v}{\partial h^{2}}=\frac{\partial\left(\Psi_{2}\right)}{\partial h}=\frac{\partial\left(\frac{1}{h_{2}}\right)}{\partial h}=\frac{-1}{\left(h_{2}\right)^{2}}\left(\frac{\partial h_{2}}{\partial v} \frac{\partial v}{\partial h}\right)=\frac{-1}{\left(h_{2}\right)^{2}} h_{22} \Psi_{2}= \\
=\frac{-1}{\left(h_{2}\right)^{2}} h_{22} \frac{1}{h_{2}}=-\frac{h_{22}}{\left(h_{2}\right)^{3}} \geq 0 \\
\Psi_{12}=\frac{\partial\left(-\frac{h_{1}}{h_{2}}\right)}{\partial h}=-\frac{\frac{\partial h_{1}}{\partial v} \frac{\partial v}{\partial h} h_{2}-h_{1} \frac{\partial h_{2}}{\partial v} \frac{\partial v}{\partial h}}{\left(h_{2}\right)^{2}}=-\frac{h_{12} \Psi_{2} h_{2}-h_{1} h_{22} \Psi_{2}}{\left(h_{2}\right)^{2}}= \\
=-\frac{\Psi_{2}\left(h_{12}+\Psi_{1} h_{22}\right)}{h_{2}}=\Psi_{21}\langle 0
\end{gathered}
$$

gdzie:

$$
\begin{aligned}
& \Psi_{11}-\text { druga pochodna funkcji } \Psi \text { względem } u, \\
& \Psi_{22} \text { - druga pochodna funkcji } \Psi \text { względem } h, \\
& \Psi_{12}-\text { pochodna funkcji } \Psi_{1} \text { względem } h, \\
& \Psi_{21} \text { - pochodna funkcji } \Psi_{2} \text { względem } u, \\
& \mathrm{~h}_{11}-\text { druga pochodna równania }(1.24) \text { względem } u, \\
& \mathrm{~h}_{22} \text { - druga pochodna równania (1.24) względem } v .
\end{aligned}
$$

Z równania (1.27) wynika, że krzywa Phillipsa wsparta oczekiwaniami adaptacyjnymi jest następującej postaci:

$$
f(u, h)=\lambda g(u, \Psi(u, h))
$$


Phelps przyjmuje następujące wartości pierwszych oraz pochodnych wyższych rzędów równania $(1.29)^{14}$ :

$$
\begin{gathered}
\frac{\partial f(u, h)}{\partial u}=\lambda\left(\frac{\partial g}{\partial u}+\frac{\partial g}{\partial v} \frac{\partial \Psi}{\partial u}\right)=\lambda\left(g_{1}+g_{2} \Psi_{1}\right)=\lambda\left(g_{1}+g_{2}\left(-\frac{h_{1}}{h_{2}}\right)\right)\langle 0 \\
\left.\frac{\partial f(u, h)}{\partial h}=h\left(\frac{\partial g}{\partial v} \frac{\partial \Psi}{\partial h}\right)=h\left(g_{2} \Psi\right)=\lambda g_{2} \frac{1}{h_{2}}\right\rangle 0 \\
\frac{\partial^{2} f(u, h)}{\partial u^{2}}=\lambda\left(g_{11}+g_{12} \Psi_{1}+\left(g_{21}+g_{22} \Psi_{1}\right) \Psi_{1}+g_{2} \Psi_{11}\right)= \\
\left.=\lambda\left(g_{11}+g_{12} \Psi_{1}+g_{22} \Psi_{1}^{2}+g_{22} \Psi_{11}\right)\right\rangle 0 \\
\frac{\partial\left(\frac{\partial f(u, h)}{\partial h}\right)}{\partial u}=\lambda\left(\left(g_{21}+g_{22} \Psi_{1}\right) \Psi_{2}+g_{2} \Psi_{21}\right)\langle 0
\end{gathered}
$$

Uzasadnienie tych ograniczeń (tzn. wartości pochodnych (1.30a)-(1.30d)) można znaleźć w omawianej koncepcji (zob. Phelps 1970, s. 147). Ujemny znak pierwszej pochodnej $f(u, h)$ względem stopy bezrobocia (nierówność (1.30a)) oznacza, że przy danym poziomie $h$ krzywa Phillipsa jest ujemnie nachylona. Dodatni znak pierwszej pochodnej $f(u, h)$ względem $h$ oznacza natomiast, że im silniejszy jest wzrost zatrudnienia przy danym poziomie stopy bezrobocia, tym wyższa musi być stopa wolnych miejsc pracy, a to z kolei będzie zwiększać presję na wzrost płac nominalnych. Taka zależność jest zgodna z teorią nadwyżkowego popytu oraz z podejściem Phillipsa-Lipseya.

Dodatni znak drugiej pochodnej równania (1.29) względem stopy bezrobocia oznacza zaś, że przy stałym poziomie $h$ relacja między stopą zmian płac a stopą bezrobocia jest wypukła, czyli wraz ze wzrostem stopy bezrobocia musi zmaleć stopa wolnych miejsc pracy, aby poziom $h$ nie uległ zmianie. Ujemny znak pochodnej mieszanej równania (1.29) - nierówność (1.30d) - oznacza, że wzrost stopy wzrostu zatrudnienia na jednostkę podaży pracy $(h)$ powoduje tym większy wzrost stopy wolnych miejsc pracy, im mniejsza jest stopa bezrobocia.

Stopa bezrobocia $(u)$ i stopa wzrostu zatrudnienia na jednostkę podaży pracy $(h)$ nie mogą w perspektywie długookresowej kształtować się niezależnie od siebie, ponieważ wysoki (niski) poziom $h$ oznacza spadek (wzrost) $u$.

$$
{ }^{14} \text { Gdzie: } \frac{\partial g}{\partial u}=g_{1} ; \quad \frac{\partial g}{\partial h}=g_{2} ; \quad \frac{\partial^{2} g}{\partial u^{2}}=g_{11} ; \quad \frac{\partial^{2} g}{\partial h^{2}}=g_{22} ; \quad \frac{\partial g_{1}}{\partial h}=g_{12} ; \quad \frac{\partial g_{2}}{\partial u}=g_{21} \text {. }
$$


Równanie krzywej Phillipsa w warunkach stanu stacjonarnego (przedstawiające zależność między stopą wzrostu płac a stałą stopą bezrobocia) Phelps wyznacza przy założeniu, że stopa wzrostu podaży pracy wynosi $\alpha \geq 0$. Zależność między stopą bezrobocia, stopą wolnych miejsc pracy oraz stopą wzrostu podaży pracy w warunkach stanu stacjonarnego opisuje równanie (1.31):

$$
\bar{h}=h(\bar{u}, v)=(1-\bar{u}) \alpha
$$

gdzie:

$\bar{h}$ - stopa wzrostu podaży pracy w warunkach stanu stacjonarnego,

$\bar{u}$ - stopa bezrobocia pracy w warunkach stanu stacjonarnego,

$\bar{v} \quad$ - stopa wolnych miejsc pracy w warunkach stanu stacjonarnego.

$\mathrm{Z}$ równania (1.31) wynika, że wraz ze wzrostem stopy bezrobocia zmaleć musi stopa wolnych miejsc pracy nie tylko dlatego, by poziom stopy wzrostu podaży pracy nie uległ zmianie, ale również po to, aby stopa wzrostu podaży pracy zmalała. Krzywa Phillipsa w warunkach stanu stacjonarnego ${ }^{15}$ jest więc ujemnie nachylona (i wypukła do początku układu współrzędnych) oraz bardziej stroma niż krzywe Phillipsa o stałym poziomie stopy wzrostu zatrudnienia $(h)$ (zob. rys. $1.2^{16}$ ).

$\mathrm{Z}$ omawianego modelu dynamiki zatrudnienia wynika, że poziom bezrobocia i wolnych miejsc pracy wpływa na stopę wzrostu podaży pracy. Przy danym poziomie $\alpha$ wpływa on również na zmianę stopy bezrobocia, co można opisać wzorem:

$$
-\dot{u}=h(u, v)-(1-u) \alpha
$$

gdzie:

$\dot{u} \quad-$ przyrost stopy bezrobocia w czasie $\left(\dot{u}=\frac{d u}{d t}\right)$.

$Z$ równania (1.32) wynika, że jeśli przy danym poziomie stopy bezrobocia $(u)$, stopa wolnych miejsc pracy jest wyższa od poziomu odpowiadającego stanowi stacjonarnemu $\left(\bar{u}^{*}\right)$, to w tej sytuacji stopa wzrostu zatrudnienia $(h)$ będzie wyższa od poziomu w warunkach stanu stacjonarnego $(h>\stackrel{+}{h}=(1-\bar{u}) \alpha)$, zaś stopa bezrobocia będzie malała. W sytuacji odwrotnej nastąpi wzrost stopy bezrobocia.

${ }^{15}$ Zgodnie z równaniami (1.29) i (1.31) przyjmuje ona postać: $f(\bar{u},(1-\bar{u}) \alpha)$. Pierwsza pochodna $\frac{\partial f}{\partial \bar{u}}<0$ implikuje, że krzywa Phillipsa w warunkach stanu stacjonarnego jest ujemnie nachylona. Ponadto Phelps przyjmuje, że druga pochodna funkcji $f(\bar{u},(1-\bar{u}) \alpha)$ ma wartość ujemną, co oznacza, że krzywa Phillipsa jest wypukła.

${ }^{16} \mathrm{Na}$ osi pionowej odłożono stopę wzrostu płac, zaś na osi poziomej stopę bezrobocia. 
Odnosząc powyższy model do całej gospodarki, Phelps dochodzi do wniosku, że w długookresowej równowadze istnieje tylko jedna stopa bezrobocia $\bar{u}^{*}$ opisana przez równanie:

$$
f\left(\stackrel{u}{*}^{*},\left(1-\bar{u}^{*}\right) \alpha\right)=0
$$

Stopie bezrobocia $\left(\bar{u}^{*}\right)$ odpowiada poziom stopy wolnych miejsc pracy W warunkach stanu stacjonarnego $\left(\bar{v}^{*}\right)$ opisany równaniem: $g\left(\bar{u}^{*}, \bar{v}^{*}\right)=0$. Każdy inny poziom stopy bezrobocia będzie oznaczał, zdaniem Phelpsa, nierównowagę. Stopa bezrobocia $\bar{u}^{*}$ jest przez niego określana mianem ,stopy bezrobocia w równowadze” lub „optymalnej ścieżki bezrobocia”.

Jak wynika $\mathrm{z}$ rys. 1.1, wzrost oczekiwanej stopy wzrostu płac o $\beta$ powoduje przesunięcie krzywej Phillipsa w warunkach stanu stacjonarnego do góry o taką samą wartość, natomiast poziom stopy bezrobocia odpowiadający obu punktom równowagi w warunkach stanu stacjonarnego nie ulega zmianie (przejście z punktu A do B). Łącząc punkty A i B otrzymamy długookresową krzywą Phillipsa (pionowa linia przerywana na wykresie, na której znajdują się punkty A i B, to długookresowa krzywa Phillipsa). Każdy punkt na tej linii ma taką samą jedną współrzędną - stopę bezrobocia równowagi.

Mechanizm dojścia do stanu długookresowej równowagi w modelu Phelpsa można opisać w następujący sposób (zob. Bludnik 2006, s. 26-27). Niespodziewany wzrost popytu na rynku produktu powoduje, że część pracowników decyduje się na porzucenie pracy w celu znalezienia lepszej oferty płacowej. Taka sytuacja oznacza, że pracodawcy będą ponosili większe koszty przyjęć i zwolnień z pracy. Aby je ograniczyć, firmy będą zmuszone do podnoszenia stopy wynagrodzeń. Wzrost wynagrodzeń prowadzi do wzrostu inflacji. Ponieważ poszukujący pracy ulegają iluzji pieniężnej, to wzrost ofert płacowych traktują jako swój sukces w poszukiwaniach pracy i są skłonni zaakceptować oferty płac. Konsekwencją tego jest spadek bezrobocia. Taki stan nie będzie trwały, ponieważ po pewnym czasie oczekiwania odnośnie płac i cen dostosują się do rzeczywistości. Pracujący niezadowoleni z poziomu osiąganych wynagrodzeń zaczną porzucać pracę, a bezrobotni wydłużą czas poszukiwań. W efekcie tych dostosowań bezrobocie powróci do stanu długookresowej równowagi. Można zatem wysnuć wniosek, że bezrobocie naturalne $u$ Phelpsa obejmuje bezrobocie wynikające z poszukiwań pracy.

Zdaniem Phelpsa, faktyczna stopa bezrobocia może tylko przejściowo odchylać się od poziomu stopy bezrobocia $\mathrm{w}$ równowadze $-\bar{u}^{*}$. Polityka pieniężna ma wpływ jedynie na wielkości nominalne, natomiast wielkości realne zmieniają się tylko przejściowo na skutek zmian podaży pieniądza.

Z koncepcji Phelpsa można wysnuć ważne wnioski dla polityki makroekonomicznej. Zwiększenie podaży pieniądza lub ekspansja fiskalna może tylko przejściowo obniżyć poziom bezrobocia poniżej stopy bezrobocia w stanie 
równowagi, ponieważ po pewnym czasie bezrobocie i tak powróci do poziomu odpowiadającego stanowi równowagi. Ekspansywna polityka pieniężna jest zatem nieskuteczna $\mathrm{w}$ walce $\mathrm{z}$ bezrobociem. Jedynym efektem ekspansji pieniężnej będzie trwałe podniesienie stopy inflacji oraz zwiększenie kosztów ograniczania inflacji w przyszłości. Według Phelpsa koszty polityki antyinflacyjnej w postaci wyższego poziomu bezrobocia są przejściowe, gdyż poziom bezrobocia po pewnym czasie powróci do stanu równowagi. Zapoczątkowane zostało $\mathrm{w}$ ten sposób nowe podejście do polityki pieniężnej. W późniejszym okresie zostało ono powszechnie przyjęte i określane mianem polityki pieniężnej stosowanej przez banki centralne, opartej na celu inflacyjnym (zob. Phelps 2006, s. 353).

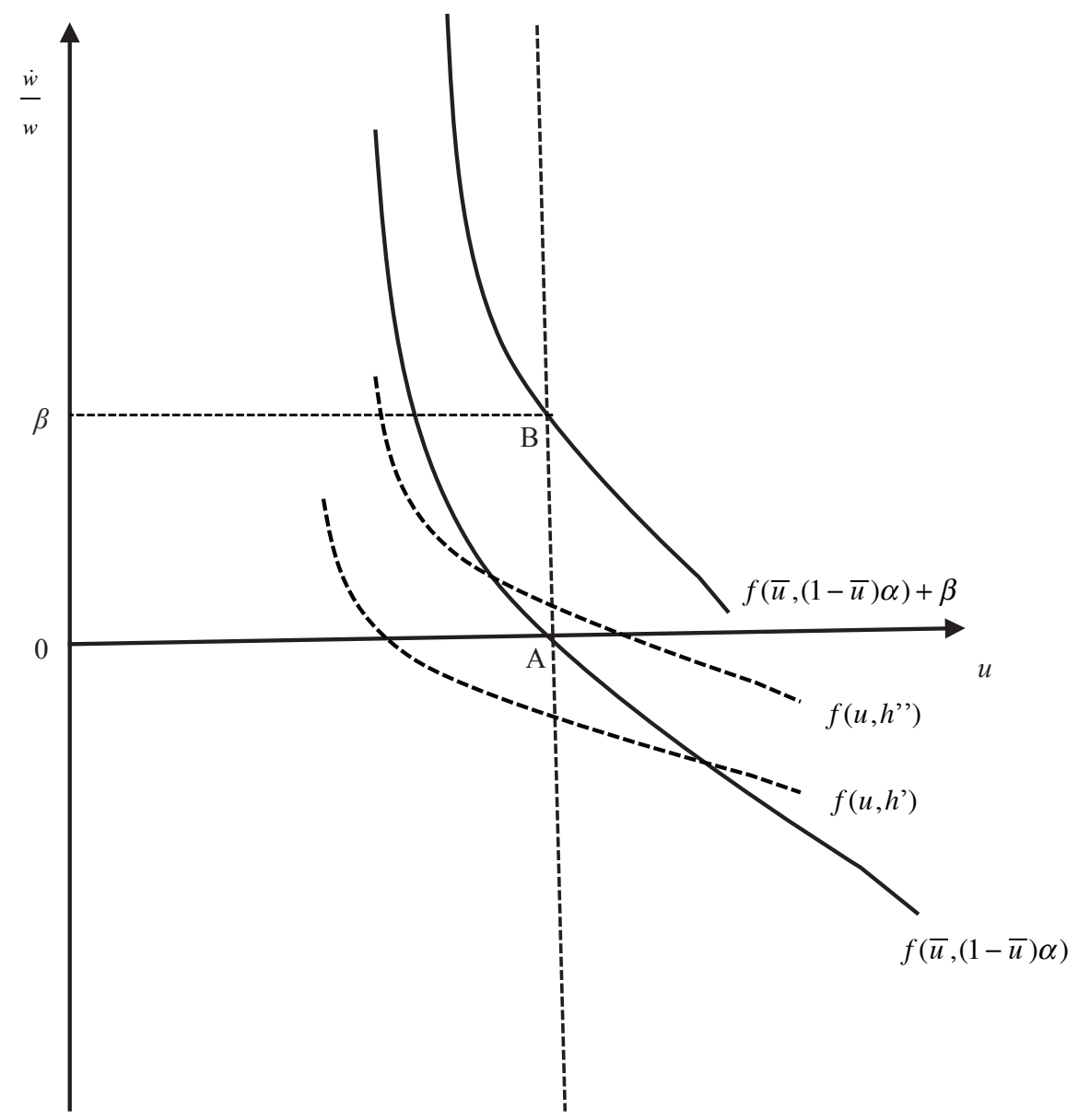

Rys. 1.1. Krzywe Phillipsa wsparte oczekiwaniami oraz ich położenie w warunkach stanu stacjonarnego

Źródło: opracowanie własne na podstawie: Phelps 1970, s. 148. 
Phelps stwierdził, że naturalna stopa bezrobocia to stopa bezrobocia w warunkach długookresowej równowagi na rynku pracy. Bezrobocie naturalne ma charakter frykcyjny, ponieważ wynika z indywidualnych decyzji osób. Według Phelpsa stopa bezrobocia w równowadze zależy do czynników realnych. Zalicza on do nich wydajność pracy oraz stopę wzrostu zasobu siły roboczej (zob. Phelps 1970, s. 158).

Koncepcja Phelpsa budzi pewne kontrowersje w literaturze ekonomicznej. Niektórzy ekonomiści nie podzielają przekonania, że po zakończeniu krótkookresowego szoku gospodarka będzie zawsze powracać do początkowego stanu stabilnej długookresowej równowagi (zob. McKenna 1985, s. 131-132).

Zgodnie z założeniami, powrót do wyjściowego poziomu równowagi dokonuje się przy założeniu stałości zasobu siły roboczej, co jest ujęciem bardzo dyskusyjnym. Wzrost ofert płacowych może bowiem skłonić część osób biernych zawodowo do powrotu (lub wejścia) na rynek pracy, co tym samym spowoduje, że krótkookresowa krzywa Phillipsa stanie się dodatnio nachylona, zaś bezrobocie ukształtuje się powyżej dotychczasowego poziomu równowagi. Oczywiście sytuacja może (raczej tylko teoretycznie) ulec odwróceniu, ale trudno jest ustalić jednocześnie zachowanie się płac i bezrobocia w rzeczywistej gospodarce (zob. McKenna 1985, s. 130-131; Bludnik 2010, s. 60) ${ }^{17}$.

Sam Phelps w późniejszych opracowaniach zwraca uwagę, że pewną słabością teorii naturalnej stopy bezrobocia jest jej uniezależnienie od zakłóceń makroekonomicznych. Te wady teorii bezrobocia równowagi skłoniły Phelpsa do jej modyfikacji w późniejszym okresie.

Pewną słabością koncepcji Phelpsa jest bardzo sformalizowana analiza przy bardzo ograniczonej interpretacji uzyskanych wyników. Zawiera ona również niezwykle enigmatyczne wnioski końcowe. To właśnie dlatego, pomimo wcześniejszej jej publikacji niż koncepcji Friedmana, teoria bezrobocia równowagi Phelpsa jest mało znana.

\subsubsection{Koncepcja naturalnej stopy bezrobocia M. Friedmana}

Przyjrzyjmy się koncepcji naturalnej stopy bezrobocia sformułowanej przez Friedmana. Nie jest tak sformalizowana, jak teoria Phelpsa. Ma ona charakter akademickiego wykładu i może właśnie dlatego jest bardziej popularna w literaturze ekonomicznej.

Friedman po raz pierwszy przedstawił swoją teorię naturalnej stopy bezrobocia na dorocznym zebraniu Amerykańskiego Towarzystwa Ekonomicznego w 1967 r., natomiast publikacja jego artykułu miała miejsce w 1968 r. W wykładzie noblowskim z 1976 r. rozwinął zaś tę koncepcję.

${ }^{17} \mathrm{Z}$ powodu występowania efektu histerezy powrót do wyjściowego poziomu wydaje się praktycznie niemożliwy. 
Jak już wspomniano, Friedman użył określenia „naturalna stopa bezrobocia" celowo, nawiązując w ten sposób do koncepcji naturalnej stopy procentowej Wicksela. Jego zdaniem na rynku pracy w każdym momencie istnieje pewien poziom bezrobocia spójny z równowagą struktury płac realnych (zob. Friedman 1968 , s. 8). Przy tym poziomie bezrobocia tempo wzrostu płac realnych jest zgodne $\mathrm{z}$ jego średnim naturalnym poziomem. Jest to najniższy poziom bezrobocia, przy którym stały pozostaje poziom cen (zob. Blaug 1994, s. 683-684). Niższy poziom bezrobocia (od jego naturalnego poziomu) prowadzić będzie do wzrostu inflacji. W sytuacji odwrotnej wystąpi tendencja spadkowa tempa wzrostu cen w gospodarce.

Naturalna stopa bezrobocia, zdaniem Friedmana, to poziom bezrobocia zgodny z walrasowskim stanem równowagi ogólnej, uwzględniający strukturalne własności rynków pracy i dóbr, niedoskonałość funkcjonowania rynków, zachodzącą w czasie zmienność popytu i podaży, ponoszone koszty zbierania informacji o wolnych miejscach pracy, dostępności siły roboczej, koszty mobilności i inne (zob. Friedman 1968, s. 8; Bludnik 2006, s. 22). Równowaga ogólna Walrasa oznacza taki stan gospodarki, w którym występuje jednoczesna równowaga między popytem i podażą na wszystkich rynkach (zob. Blaug 1994, s. 582). W warunkach równowagi żaden z podmiotów rynkowych nie chce zmiany tego stanu. Naturalna stopa bezrobocia to zatem taki poziom bezrobocia, który zapewnia równowagę między popytem a podażą i z którego wynika poziom płac realnych zgodny z walrasowską równowagą ogólną.

Według Friedmana polityka pieniężna ma dwa najważniejsze ograniczenia (zob. Friedman 1968, s. 5). Po pierwsze, pozwala ona na utrzymywanie stopy procentowej na określonym poziomie tylko przez pewien, bardzo ograniczony okres. Po drugie, stopa bezrobocia może być utrzymywana na określonym poziomie przy pomocy polityki pieniężnej jedynie przez bardzo krótki okres.

Zdaniem Friedmana analiza przeprowadzona przez A. W. Phillipsa, pomimo dużego znaczenia dla polityki gospodarczej, ma jedną podstawową wadę - brakuje w niej rozróżnienia pomiędzy płacami nominalnymi a realnymi. Pomimo tego, że w negocjacjach między pracodawcami a związkami zawodowymi ustalane są płace nominalne, to pracownicy są w rzeczywistości zainteresowani poziomem płac realnych. W procesie negocjacji płacowych, podczas których ustalany jest poziom przyszłych wynagrodzeń, pracownicy biorą pod uwagę stopę oczekiwanej inflacji. Według Friedmana płace zależą nie tylko od poziomu bezrobocia, ale również od oczekiwanej stopy inflacji. Oznacza to, że w rzeczywistości może występować wiele krzywych Phillipsa reprezentujących różny oczekiwany poziom inflacji, co przedstawiono na rys. 1.2. Krótkookresowej krzywej Phillipsa $S R C_{1}$ odpowiada oczekiwany poziom stopy inflacji $\pi_{1}^{e}$, zaś wyżej położonej krzywej $S R C_{2}$ odpowiada poziom oczekiwanej stopy inflacji $\pi_{2}{ }^{e}$. Można więc powiedzieć, że im wyższy jest poziom oczekiwań inflacyjnych, tym wyżej położona jest krótkookresowa krzywa Phillipsa. Wzrost oczekiwań inflacyjnych przenosi 
gospodarkę na coraz wyżej położoną krótkookresową krzywą Phillipsa. Krótkookresowe krzywe Phillipsa pozwalają na wyznaczenie długookresowej krzywej Phillipsa $L R C$, która wyznacza poziom naturalnej stopy bezrobocia $u n$.

Friedman (tak samo jak Phelps) dopuszcza możliwość wymienności między inflacją i bezrobociem jedynie w krótkim okresie. Faktyczna stopa bezrobocia ( $u f$ ) może się odchylać od naturalnej stopy bezrobocia tylko przejściowo, natomiast w okresie długim bezrobocie ustala się na poziomie odpowiadającym naturalnej stopie bezrobocia $u n$.

Według Friedmana podstawowym wyjaśnieniem zamienności między inflacją i bezrobociem są nieoczekiwane zmiany nominalnego popytu na dobra i usługi. W warunkach nieustannych zmian wielkości relatywnego popytu na dobra i usługi producenci nie są w stanie rozstrzygnąć, czy zmiana popytu dotyczy zapotrzebowania na ich produkty. Nie są oni również w stanie określić, czy jest to zjawisko powszechne w całej gospodarce. W reakcji na wzrost popytu producenci zwiększą produkcję i zatrudnienie, ponieważ w tej sytuacji uzyskują większe dochody ze sprzedaży swoich produktów. Producenci będą również skłonni do podniesienia płac nominalnych, aby zachęcić do podjęcia pracy dodatkowych pracowników. Pomimo podniesienia płac nominalnych wzrost cen produktów sprawia, że w odczuciu pracodawców maleje płaca realna, co skłoni ich do zwiększenia popytu na pracę.

Wzrost płacy nominalnej, z powodu iluzji pieniężnej, jest przez pracowników postrzegany jako wzrost ich płac realnych. W rezultacie zwiększą oni podaż pracy. Wzrost popytu na pracę spowoduje, że przejściowo bezrobocie odchyli się od swojego naturalnego poziomu i wyniesie np. uf (zob. rys. 1.2), co obrazuje przejście z punktu A do C. Procesy te nie będą jednak trwałe. W okresie długim zmiany nominalnego popytu i cen zostaną przez pracowników i producentów właściwie rozpoznane. Pracownicy zorientują się, że na skutek wzrostu cen ich wynagrodzenia realne zmalały i zażądają podwyżek płac. Wzrost płac spowoduje spadek popytu na pracę i powrót bezrobocia do poziomu odpowiadającego naturalnej stopie bezrobocia (un), jednakże przy wyższym poziomie oczekiwanej stopy inflacji. Na rys. 1.2 ilustruje to przejście z punktu C do punktu B.

Z koncepcji naturalnej stopy bezrobocia Friedmana wynikają podobne wnioski dla polityki gospodarczej, jak z koncepcji Phelpsa. Wzrost agregatowego popytu (wywołany zwiększeniem wydatków rządowych lub zwiększeniem podaży pieniądza) może obniżyć stopę bezrobocia poniżej naturalnej stopy bezrobocia tylko przejściowo ${ }^{18}$. W długim okresie bezrobocie powróci do naturalnego poziomu. Długofalowym skutkiem takiej polityki będzie natomiast przyspieszenie procesów inflacyjnych $\mathrm{w}$ gospodarce.

${ }^{18}$ Gdyby rząd zdecydował się na trwałe utrzymywanie bezrobocia poniżej naturalnej stopy bezrobocia, to wiązałoby się to ze znacznym przyspieszeniem procesów inflacyjnych w gospodarce, aż do hiperinflacji włącznie. Oczywiście taką możliwość w gospodarce rynkowej można rozpatrywać tylko teoretycznie. 


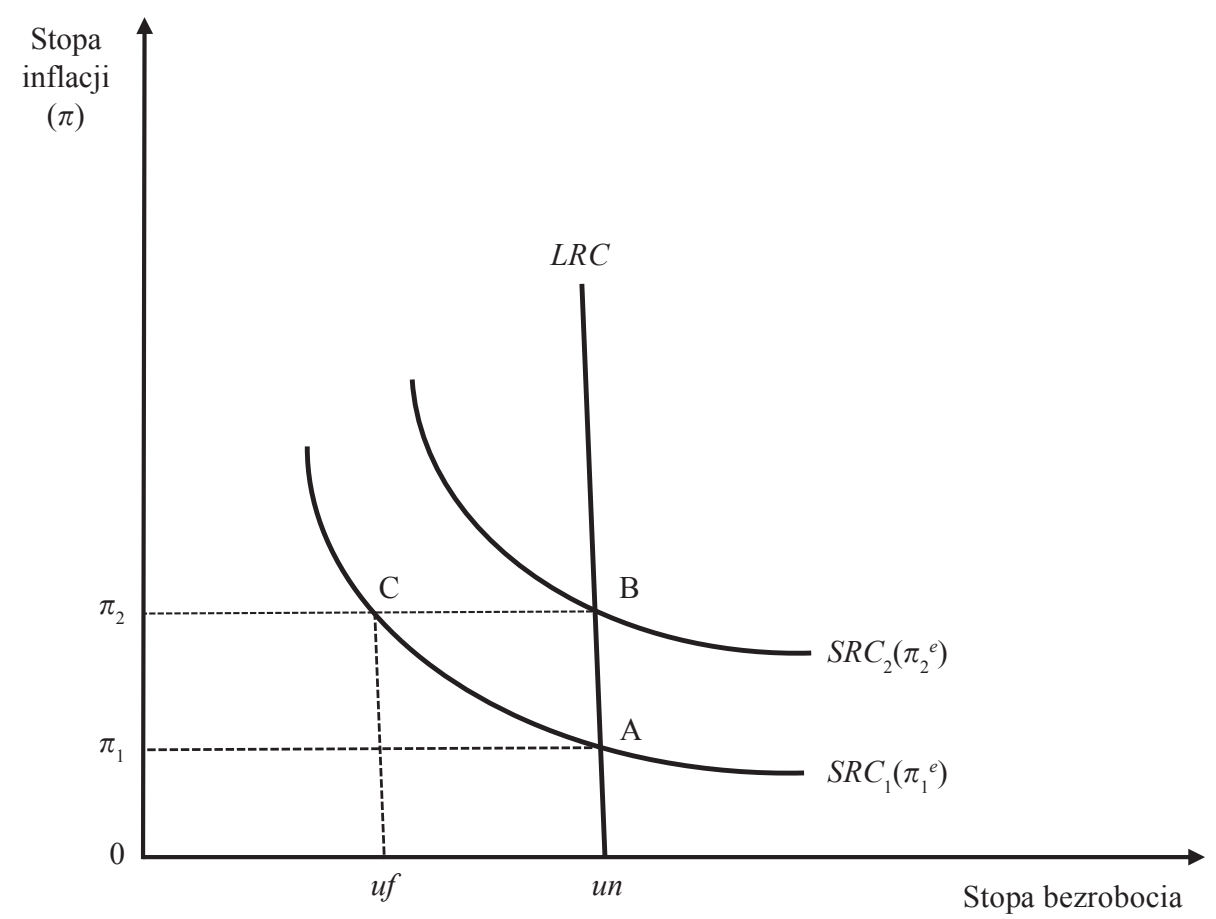

(u)

Rys. 1.2. Bezrobocie naturalne a bezrobocie faktyczne

Źródło: opracowanie własne na podstawie: Friedman 1977, s. 457.

Określenie „naturalna stopa bezrobocia” może jednak sugerować, iż jest to normalna stopa bezrobocia, której nie można zmienić. Wysokość stopy bezrobocia równowagi może się zmieniać. Naturalna stopa bezrobocia jest wielkością egzogeniczną. Może się ona zmieniać pod wpływem czynników realnych. Kwestie redukcji bezrobocia równowagi są jednak stosunkowo słabo rozwinięte również w koncepcji Friedmana. Tak samo jak Phelps, Friedman akcentuje przede wszystkim rolę polityki pieniężnej w ograniczaniu poziomu inflacji. O czynnikach wpływających, jego zdaniem, na poziom bezrobocia równowagi wypowiedział się w wywiadzie opublikowanym w książce B. Snowdona, H. Vane'a, P. Wynarczyka (1998). Powiedział on w nim, że najlepszym środkiem na obniżenie naturalnej stopy bezrobocia jest liberalizacja rynku siły roboczej, wyeliminowanie działań prowadzących do powstawania kontyngentów siły roboczej, likwidacja płacy minimalnej oraz rynkowe kształtowanie się płac (zob. Snowdon, Vane, Wynarczyk 1998, s. 188).

Należy podkreślić, że determinanty naturalnej stopy bezrobocia prezentowane w literaturze ekonomicznej są rezultatem interpretacji przez poszczególnych autorów obu koncepcji naturalnej stopy bezrobocia. Wysokość naturalnej stopy 
bezrobocia zależy od szeregu takich czynników realnych, jak (zob. Robinson 1986, s. 350-352; Kwiatkowski 2002a, s. 147):

- efektywność funkcjonowania urzędów pracy,

- przepływ informacji o wolnych miejscach pracy,

- stopień uzwiązkowienia,

- wysokość płacy minimalnej,

- wysokość kosztów pracy,

- elastyczność płac,

- koszty szkoleń,

- poziom mobilności siły roboczej,

- technologia, wydajność pracy oraz zmiany struktury produkcji,

- koszty zbierania informacji o dostępnej sile roboczej oraz o wolnych miejscach pracy,

- wysokość zasiłków dla bezrobotnych oraz okres ich pobierania,

- wysokości płacy progowej,

- struktura zasobu siły roboczej.

Przyjrzyjmy się mechanizmom wpływu poszczególnych czynników zakładanych w teorii naturalnej stopy bezrobocia na poziom bezrobocia równowagi. Poprawa efektywności funkcjonowania urzędów pracy oraz usprawnienie przepływu informacji o wolnych miejscach pracy powoduje skrócenie okresu poszukiwania pracy, co z kolei prowadzi do obniżenia poziomu bezrobocia równowagi.

Zmniejszenie stopnia uzwiązkowienia powoduje osłabienie pozycji pracowników w negocjacjach płacowych i tym samym do obniżenia bezrobocia równowagi. Wynika to z tego, że im niższy stopień uzwiązkowienia, tym słabsza jest pozycja negocjacyjna związków zawodowych w negocjacjach dotyczących podwyżek płac.

Wzrost płacy minimalnej prowadzi do spadku popytu na pracę i wzrostu bezrobocia. Ponadto, ma on negatywny wpływ na strukturę siły roboczej (zob. Socha, Sztanderska 2000, s. 55). Może bowiem powodować wzrost szarej strefy. Podwyższanie płacy minimalnej zmniejsza popyt na pracę osób o najniższych kwalifikacjach oraz bez doświadczenia zawodowego (czyli przede wszystkim absolwentów wchodzących na rynek pracy).

Obniżenie kosztów szkoleń, zmniejszenie kosztów pracy prowadzi do obniżenia ogólnych kosztów ponoszonych przez pracodawców, co z kolei prowadzi do wzrostu popytu na pracę i spadku bezrobocia równowagi.

Zwiększenie elastyczności płac powoduje wzrost popytu na pracę i w rezultacie spadek bezrobocia równowagi.

Zwiększenie mobilności siły roboczej pozwala na ograniczenie niedopasowań strukturalnych na rynku pracy, co powoduje spadek poziomu bezrobocia równowagi. 
Obniżenie zasiłków dla bezrobotnych powoduje zmniejszenie stopy kompensacji, co wywołuje skrócenie okresu poszukiwań pracy i w konsekwencji może prowadzić do zmniejszenia poziomu bezrobocia równowagi. Z kolei skrócenie okresu pobierania zasiłków powoduje zwiększenie intensywności poszukiwań pracy, co skutkuje obniżeniem poziomu naturalnej stopy bezrobocia.

Struktura zasobu siły roboczej może również wpływać na poziom bezrobocia równowagi. Osoby młode, kobiety oraz pracujące w niepełnym wymiarze czasu pracy zazwyczaj częściej zmieniają miejsca pracy, co powoduje wzrost bezrobocia frykcyjnego i tym samym podnosi poziom naturalnej stopy bezrobocia (Robinson 1986, s. 350-352).

Z koncepcji naturalnej stopy bezrobocia (sformułowanej niezależnie przez M. Friedmana oraz E. S. Phelpsa) wynikają istotne wnioski dla polityki antyinflacyjnej: przyspieszenie procesów inflacyjnych jest obserwowane, gdy bezrobocie faktyczne kształtuje się poniżej bezrobocia naturalnego ${ }^{19}$. Jeśli bezrobocie faktyczne jest wyższe od bezrobocia naturalnego, to wówczas następuje osłabienie procesów inflacyjnych w gospodarce. Koszty restrykcyjnej polityki pieniężnej (wyrażone wzrostem bezrobocia) są jednak tylko przejściowe (Kwiatkowski 2002a, s. 145). Obniżenie podaży pieniądza doprowadzi do przejściowego wzrostu bezrobocia powyżej poziomu równowagi, gdyż po pewnym czasie mechanizmy rynkowe obniżą je do poziomu naturalnej stopy bezrobocia (zob. Friedman 1968, s. 8).

\subsection{Teoria NAIRU}

Prekursorami tej teorii są F. Modigliani oraz L. Papademos, którzy w 1975 r. opublikowali koncepcję NIRU (ang. Non-Inflationary Rate of Unemployment), czyli nieinflacyjnej stopy bezrobocia. Ich celem było pogodzenie interpretacji monetarystycznej (czyli pionowej) i tradycyjnej krzywej Phillipsa (zob. Modigliani, Papademos 1975, s. 143-145). Ilustrację graficzną koncepcji NIRU stanowi rys. 1.3. Linia $F F^{\prime}$ to pionowa (monetarystyczna) krzywa Phillipsa, zaś krzywa $P P^{\prime}$ to tradycyjna krzywa Phillipsa. Punkt przecięcia pionowej krzywej Phillipsa z osią OX wyznacza poziom NIRU zgodny z podejściem monetarystycznym. Jeśli poziom bezrobocia przewyższa NIRU, to pojawia się wówczas tendencja do spadku inflacji. Z kolei poziom NIRU zgodny z tradycyjną krzywą Phillipsa wyznacza punkt przecięcia się krzywej $P P^{\prime}$ z poziomą linią ilustrującą poziom stopy inflacji w wysokości $2 \%$. Taki poziom inflacji jest traktowany przez twórców koncepcji NIRU jako „mało znaczący”. Z uwagi na to,

${ }^{19} \mathrm{~W}$ latach 70. XX w. czołowi przedstawiciele nowej makroekonomii klasycznej - R. E. Lucas (1972), T. J. Sargent i N. Wallace (1975) - wysunęli hipotezę o neutralności polityki pieniężnej zarówno w długim, jak i w krótkim okresie. 
że zdaniem twórców teorii nie można ustalić dokładnego położenia tego punktu przecięcia obu linii, poziom NIRU może znajdować się zarówno na lewo, jak i na prawo od tego punktu, co ilustruje zacieniowany obszar. $Z$ rys. 1.3 wynika, że bez względu na to, czy krzywa Phillipsa jest pionowa czy ujemnie nachylona, poziom NIRU jest taki sam.

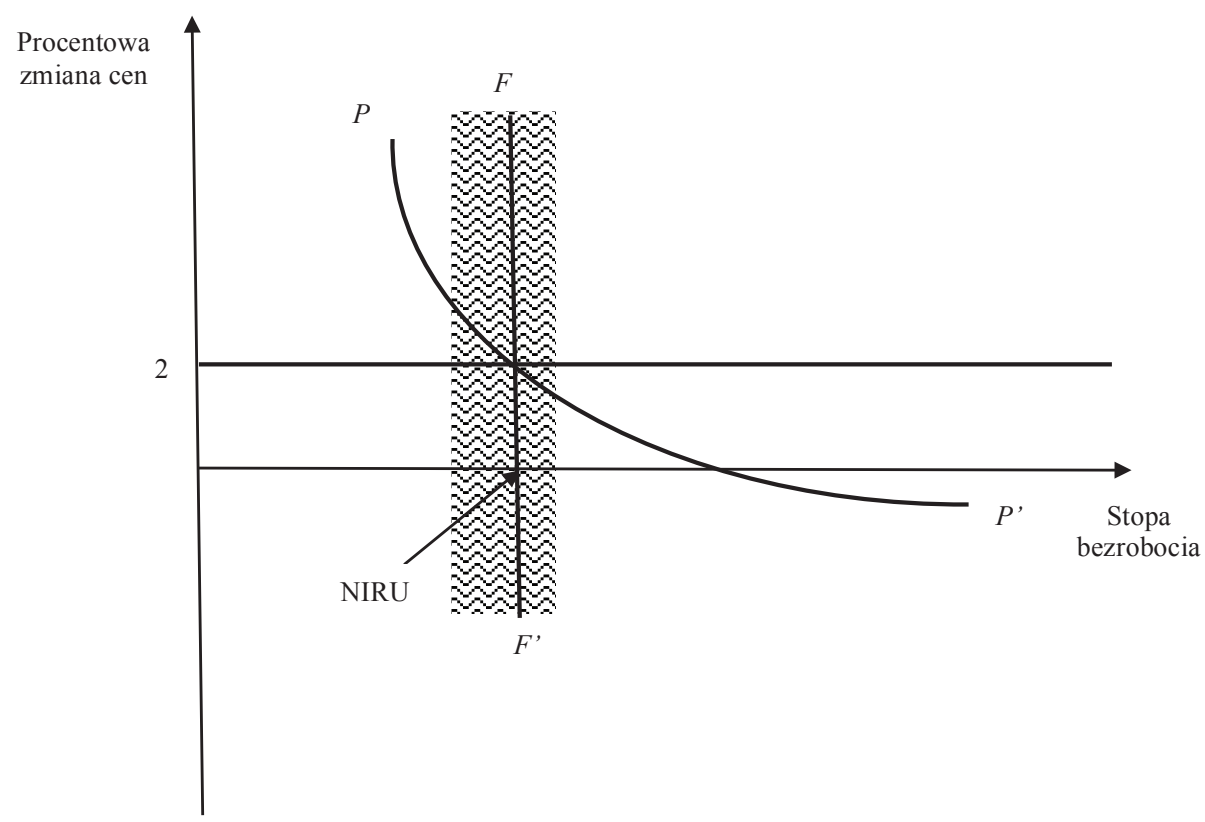

Rys. 1.3. Koncepcja NIRU

Źródło: Modigliani, Papademos 1975, s. 146.

$\mathrm{Z}$ analiz empirycznych przeprowadzonych przez obu autorów wynika, że poziom NIRU zależy od struktury siły roboczej. Przyjęli oni, że w latach 1953-1974 w USA poziom NIRU wynosił ok. 6\% (zob. Modigliani, Papademos 1975, s. 151). Metody ekonometryczne zastosowane przez Modiglianiego i Papademosa były jednak mało precyzyjne. Trudno zatem uznać ich szacunki za wiarygodne.

Teoria bezrobocia NAIRU została sformułowana w latach 80 . XX w. m.in. przez R. Layarda, S. Nickella i R. Jackmana $(1991)^{20}$. W koncepcji tej przyjmuje się, że podmioty funkcjonujące na rynku pracy dysponują niepełnym zasobem informacji o poziomie i relacjach cen. Podkreśla się ponadto mikroekonomiczne fundamenty stopy bezrobocia NAIRU.

${ }^{20}$ Nazwa NIRU została w późniejszym okresie zastąpiona przez nazwę NAIRU. W ramach tego nurtu powstała również koncepcja NAWRU, czyli stopy bezrobocia nieprzyspieszającej wzrostu płac (ang. non-accelerating wage rate of unemployment). 
Twórcy teorii NAIRU, podobnie jak Friedman i Phelps, nawiązują do związku między bezrobociem i inflacją, czyli do krzywej Phillipsa. Zwracają oni uwagę, że przy niskim bezrobociu występuje nasilenie presji inflacyjnej (spowodowanej wzrostem siły przetargowej związków zawodowych w negocjacjach płacowych i wzrostem płac). Gdy bezrobocie jest wysokie, presja inflacyjna ulega osłabieniu (ze względu na wzrost zagrożenia bezrobociem pracownicy nie wysuwają żądań płacowych i akceptują oferowane stawki płac). W konsekwencji twórcy koncepcji NAIRU dochodzą do wniosku, że istnieje stopa bezrobocia, która stabilizuje procesy inflacyjne. Ilustrację zależności między poziomem bezrobocia a dynamiką procesów inflacyjnych przedstawia rys. 1.4. Punkt przecięcia się krzywej przedstawiającej zależność między zmianami stopy inflacji a stopą bezrobocia $\mathrm{z}$ osią OX wyznacza poziom stopy bezrobocia NAIRU $\left(u^{*}\right)$.

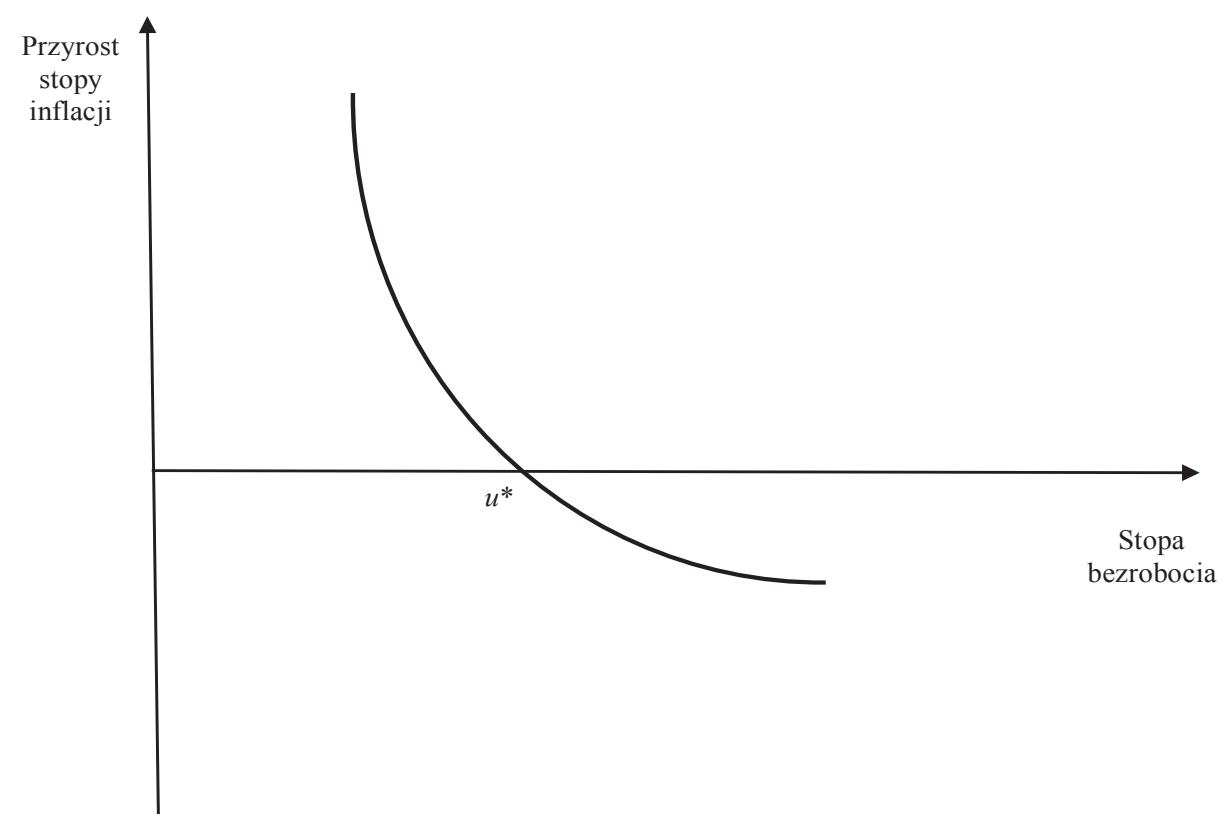

Rys. 1.4. Zależność między inflacją a bezrobociem - NAIRU

Źródło: opracowanie własne.

Zrównanie obserwowanej stopy bezrobocia $\mathrm{z}$ poziomem zgodnym $\mathrm{z}$ bezrobociem NAIRU oznacza stabilizację inflacji cen (płac nominalnych). Zgodnie $z$ teorią NAIRU, poziom bezrobocia równowagi wyznaczony jest przez zrównanie postulowanych płac realnych z realistycznymi płacami realnymi (zob. Layard 1986, s. 34-35). W tej sytuacji następuje stabilizacja procesów inflacyjnych. Jeśli postulowane płace realne są wyższe od realistycznych płac realnych, to wówczas w gospodarce następuje przyspieszenie procesów inflacyjnych. 
Nieco bardziej sformalizowaną analizę determinantów NAIRU można znaleźć w pracy Layarda, Nickella i Jackmana (2005). Załóżmy, że spełnione są oczekiwania odnośnie kształtowania płac realnych i cen w gospodarce (czyli oczekiwane płace realne są równe rzeczywistym płacom realnym, a oczekiwany poziom cen jest równy faktycznemu poziomowi cen). W modelu spirali cenowo-płacowej przyjmuje się, że równanie opisujące kształtowanie się płac realnych w gospodarce jest w postaci (zob. Layard, Nickell, Jackman 2005, s. $12-14)^{21}$ :

$$
w-p^{e}=\beta_{0}-\beta_{1} u \quad \beta_{0}>0, \beta_{1} \geq 0
$$

gdzie:

$w$ - nominalna stawka płac,

$p^{e}$ - oczekiwany poziom cen,

$u$ - faktyczna stopa bezrobocia,

$\beta_{1}$ - elastyczność płac realnych względem stopy bezrobocia,

$\beta_{0}$ - stała odzwierciedlająca wpływ różnych czynników na kształtowanie się płac.

Równanie (1.34a) opisuje zachowanie się pracowników lub związków zawodowych w procesie negocjacji płacowych. Graficzną ilustracją równania (1.34a) jest krzywa postulowanych płac realnych nazywana w modelu Layarda, Nickella, Jackmana, krzywą płac (zob. rys. 1.5). Z równania (1.34a) wynika, że wysokość płac realnych oczekiwanych przez pracowników lub związki zawodowe jest malejącą funkcją stopy bezrobocia ${ }^{22}$.

Równanie opisujące kształtowanie się cen w relacji do oczekiwanego poziomu płac ma następującą postać:

$$
p-w^{e}=\gamma_{0}-\gamma_{1} u \quad \gamma_{0}>0, \gamma_{1}>0
$$

gdzie:

$w^{e}$ - oczekiwany poziom płac nominalnych,

$p$ - poziom cen,

$\gamma_{0}$ - stała odzwierciedlająca wpływ różnych czynników na kształtowanie się cen (np. takich jak poziom konkurencyjności na rynku produktu),

$\gamma_{1}$ - parametr opisujący wrażliwość cen na zmiany stopy bezrobocia.

Graficzną ilustracją równania (1.34b) jest krzywa realistycznych płac realnych (w omawianym modelu nazywana jest ona krzywą cen) (zob. rys. 1.5).

${ }^{21}$ Wszystkie zmienne (oprócz parametrów oraz stopy bezrobocia) w równaniach 1.34a, 1.34b, $1.36 \mathrm{a}, 1.36 \mathrm{~b}$ oraz $1.36 \mathrm{c}$ są wielkościami zlogarytmowanymi.

${ }^{22}$ Postulowane płace realne zależą nie tylko od poziomu bezrobocia. Ich determinanty zostaną przedstawione $\mathrm{w}$ dalszej części niniejszej pracy. 
Przyjmuje się tutaj, że firmy ustalają ceny swoich produktów jako narzut na oczekiwane płace. $Z$ równania (1.34b) wynika, że wraz ze spadkiem stopy bezrobocia firmy będą ustalać coraz wyższe ceny.

a) równowaga na rynku pracy

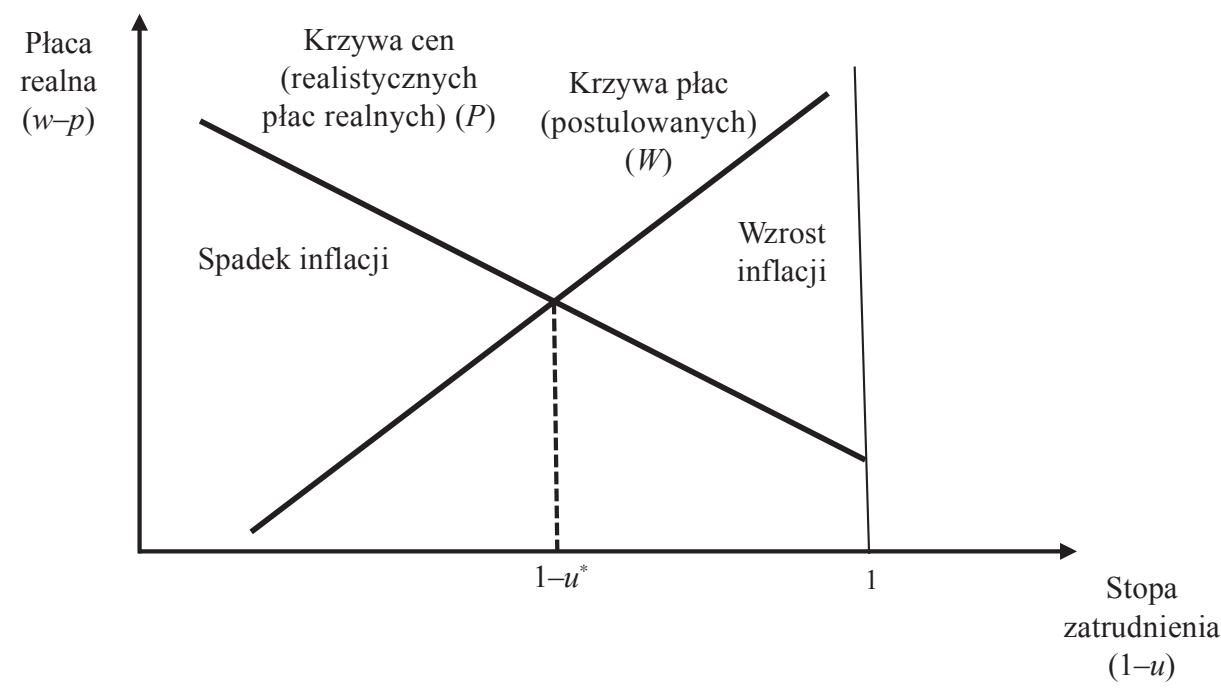

b) relacja między inflacją a bezrobociem

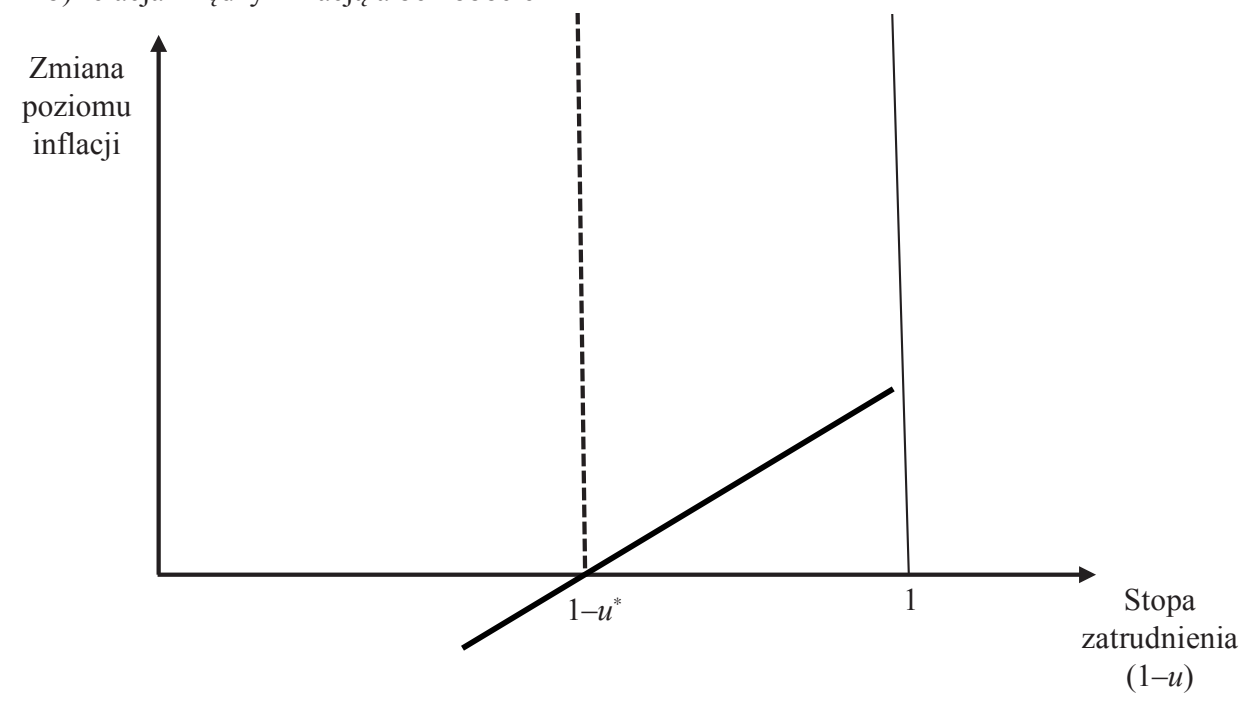

Rys. 1.5. Inflacja a bezrobocie

Źródło: Layard, Nickell, Jackman 2005, s. 14.

W długookresowej równowadze spirala cenowo-płacowa zanika, a zatem rozwiązując układ równań (1.34a)-(1.34b) (przy założeniu, że $p=p^{e}$ oraz $\left.w=w^{e}\right)$ 
otrzymujemy poziom stopy bezrobocia w równowadze, która stabilizuje procesy inflacyjne w gospodarce, czyli poziom stopy bezrobocia NAIRU:

$$
u^{*}=\frac{\beta_{0}+\gamma_{0}}{\beta_{1}+\gamma_{1}}
$$

gdzie:

$u^{*}$ - stopa bezrobocia $\mathrm{w}$ równowadze na rynku pracy, czyli stopa bezrobocia NAIRU.

$Z$ równania (1.35) wynika, że stopa bezrobocia NAIRU rośnie wraz ze wzrostem parametrów $\beta_{0} \mathrm{i} \gamma_{0}$, natomiast zmniejszenie elastyczności cen i płac realnych względem faktycznej stopy bezrobocia powoduje spadek stopy bezrobocia NAIRU23 . Graficzną ilustrację równań (1.34a), (1.34b) oraz (1.35) stanowi rys. 1.5 .

Część a) rys. 1.5 pokazuje równowagę na rynku pracy. Przedstawiono na nim krzywą cen (krzywą realistycznych płac realnych) oraz krzywą płac (krzywą postulowanych płac realnych). Postulowane płace realne są rosnącą funkcją stopy zatrudnienia, czyli tym samym malejącą funkcją stopy bezrobocia. Z kolei realistyczne płace realne maleją wraz ze wzrostem stopy zatrudnienia.

Punkt przecięcia się krzywej cen z krzywą płac wyznacza poziom stopy zatrudnienia w stanie równowagi $\left(1-u^{*}\right)$, czyli tym samym poziom stopy bezrobocia NAIRU, która stabilizuje procesy inflacyjne w gospodarce. Część wspólna obszaru poniżej krzywej cen oraz powyżej krzywej płac (na lewo od punktu przecięcia obu krzywych) reprezentuje zbiór punktów, w których następuje osłabienie procesów inflacyjnych.

Z kolei część wspólna obszaru powyżej krzywej cen i poniżej krzywej płac (na prawo od punktu przecięcia obu krzywych) jest zbiorem punktów, w których nastąpi przyspieszenie procesów inflacyjnych ${ }^{24}$. Zmiana położenia krzywej płac lub krzywej cen powoduje zmianę poziomu stopy bezrobocia NAIRU.

Część b) rys. 1.5 przedstawia zależność między poziomem cen a stopą zatrudnienia, czyli krótkookresową krzywą Phillipsa. Wraz ze wzrostem stopy za-

${ }^{23}$ Kierunek zależności można określić na podstawie wartości pierwszych pochodnych:

$$
\frac{\partial u^{*}}{\partial \beta_{0}}=\frac{\partial u^{*}}{\partial \gamma_{0}}=\frac{1}{\beta_{1}+\gamma_{1}}>0 ; \frac{\partial u^{*}}{\partial \gamma_{0}}=\frac{\partial u^{*}}{\partial \beta_{1}}=\frac{-\left(\beta_{0}+\gamma_{0}\right)}{\left(\beta_{1}+\gamma_{1}\right)^{2}}<0
$$

${ }^{24} \mathrm{Z}$ analiz empirycznych wynika, że obniżenie faktycznej stopy bezrobocia poniżej NAIRU nie powoduje znaczącego przyspieszenia procesów inflacyjnych. J. E. Stiglitz wykazał, że utrzymywanie faktycznej stopy bezrobocia o 1 punkt procentowy poniżej NAIRU spowoduje wzrost inflacji w przedziale od 0,3 do 0,6 punktu procentowego (zob. Stiglitz 1997, s. 3-10). Podobny wynik uzyskał D. M. Gordon (1988). Według jego szacunków utrzymywanie przez FED stopy bezrobocia poniżej NAIRU przez rok spowodowałoby wzrost inflacji o 0,33 punktu procentowego (zob. Gordon 1988, s. 117-123). Należy jednak zwrócić uwagę, że inflacja ma tendencję do samonapędzania się. Ponadto, z uwagi na niedokładności oszacowań NAIRU, rzeczywisty wzrost inflacji może okazać się wyższy od tego, który wynika z modelu ekonometrycznego. 
trudnienia (spadkiem stopy bezrobocia) rośnie stopa inflacji. Spadek stopy zatrudnienia (wzrost stopy bezrobocia) przyczynia się natomiast do osłabienia procesów inflacyjnych w gospodarce.

W pracy Layarda, Nickella i Jackmana można znaleźć rozwinięcie modelu opisanego równaniami (1.34a), (1.34b) oraz (1.35) (zob. Layard, Nickell, Jackman 2005, s. 378). Równanie płac w rozwiniętym modelu (przy założeniu, że $w^{e}=w$ oraz $\left.p=p^{e}\right)$ jest następującej postaci:

$$
\begin{gathered}
w-p=\beta_{0}-\beta_{1} u-\beta_{11} \Delta u-\beta_{2} \Delta^{2} p+z_{w}+\beta_{3}(k-l) \\
\beta_{0}, \beta_{2}, \beta_{3}>0, \beta_{1} \geq 0
\end{gathered}
$$

gdzie:

$k \quad$ - zasób kapitału,

$l$ - zatrudnienie,

$\Delta^{2} p$ - drugi przyrost różnicowy poziomu cen,

$z_{w} \quad$ - hojność systemu zasiłkowego oraz dostępność zasiłków dla bezrobotnych,

$\beta_{0}, \beta_{1}, \beta_{11}, \beta_{2}, \beta_{3}$ - parametry.

Równanie cen w rozwiniętym modelu (przy założeniu, że $p^{e}=p$ ) jest postaci:

$$
p-w=\gamma_{0}-\gamma_{1} u-\gamma_{11} \Delta u-\gamma_{2} \Delta^{2} p-\gamma_{3}(k-l) \quad \gamma_{0}, \gamma_{1}, \gamma_{11}, \gamma_{2}, \gamma_{3}>0
$$

gdzie:

$\gamma_{0}, \gamma_{1}, \gamma_{11}, \gamma_{2}, \gamma_{3}$ - parametry.

Zależność między bezrobociem a wielkością agregatowego popytu opisuje równanie (1.36c):

$$
y_{d}-\bar{y}=-\alpha u \quad \alpha \in(0,1)
$$

gdzie:

$y_{d}$ - agregatowy popyt (wielkość produkcji),

$\bar{y}-$ produkt potencjalny,

$\alpha \quad$ - elastyczność funkcji produkcji względem nakładów kapitału.

W modelu tym zakłada się, że nie występują szoki technologiczne. Ponadto, wielkość agregatowego popytu traktowana jest jako wielkość egzogeniczna. Rozwiązaniem równań (1.36a)-(1.36c) jest stopa bezrobocia w równowadze opisana równaniem (1.36d):

$$
u^{*}=\frac{\left(\beta_{0}+\gamma_{0}\right)+z_{w}}{\beta_{1}+\gamma_{1}}
$$


$\mathrm{Z}$ równania (1.36d) wynika, że im wyższy parametr $z_{w}$, tym wyższy poziom stopy bezrobocia w równowadze. Pozostałe wielkości w tym równaniu wpływają na poziom stopy bezrobocia $\mathrm{w}$ równowadze $\mathrm{w}$ tym samym kierunku, jak w równaniu (1.35).

Poziom NAIRU, tak samo jak poziom naturalnej stopy bezrobocia, zależy od czynników realnych. Stopa bezrobocia NAIRU może ulec zmianie pod wpływem czynników oddziałujących na poziom realistycznych i postulowanych płac realnych. Poziom realistycznych płac realnych (czyli płac odpowiadających możliwościom ekonomicznym gospodarki) zależy przede wszystkim od poziomu wydajności pracy. Wzrost wydajności pracy stwarza możliwość podniesienia płac bez przyspieszenia procesów inflacyjnych. Wzrost realistycznych płac realnych powoduje przy założeniu ceteris paribus spadek stopy bezrobocia NAIRU.

Poziom postulowanych płac realnych zależy z kolei od: sytuacji na rynku pracy (czyli poziomu stopy bezrobocia), hojności systemu zasiłków dla bezrobotnych, stopnia ochrony stosunków pracy, siły związków zawodowych w negocjacjach płacowych, pozycji ,insiderów”25, udziału bezrobocia długookresowego oraz niedopasowań strukturalnych między podażą pracy i popytem na pracę (zob. Layard, Nickell, Jackman 2005, s. 13-48; Kwiatkowski 2002a, s. 150).

Wpływ poszczególnych determinant postulowanych płac realnych jest następujący. Wzrost stopy bezrobocia (będący symptomem pogorszenia sytuacji na rynku pracy) prowadzi do obniżenia postulowanych płac realnych ze względu na wzrost konkurencji o miejsca pracy, co z kolei prowadzi do obniżenia NAIRU. Poprawa sytuacji na rynku pracy prowadzić będzie do wzrostu postulowanych płac realnych i w konsekwencji wzrostu stopy bezrobocia NAIRU.

Wzrost intensywności poszukiwań zmniejsza poziom postulowanych płac realnych. Spadek presji na wzrost płac obniża poziom NAIRU. Większa intensywność poszukiwań pracy przez osoby bezrobotne oznacza, że wolne miejsca pracy są szybciej zajmowane, czyli tym samym krótszy jest okres poszukiwań. Ponadto, większa intensywność poszukiwań zwiększa konkurencję między pracującymi i bezrobotnymi, zniechęcając tych pierwszych do windowania postulatów płacowych (zob. Layard, Nickell, Jackman 2005, s. 34-35).

Zwiększenie stopnia ochrony zatrudnienia prowadzi do wzrostu postulatów płacowych (czyli wzrostu postulowanych płac realnych) i w konsekwencji wzrostu poziomu bezrobocia równowagi (NAIRU) (zob. Layard, Nickell, Jackman 2005, s. 74). Wysokie koszty zwolnień z pracy oraz długie okresy wypowiedzenia zachęcają pracowników do wysuwania żądań podwyżek płac.

\footnotetext{
${ }^{25}$ Model ,insider - outsider” zostanie przedstawiony w podrozdziale 1.7.
} 
Im większa hojność systemu zasiłków dla bezrobotnych (tzn. wyższa wysokość zasiłków, łatwość uzyskania zasiłku, dłuższy okres jego pobierania), tym większa presja na wzrost postulowanych płac realnych, co w konsekwencji prowadzi do wzrostu NAIRU. Zwiększenie hojności systemu zasiłków dla bezrobotnych zmniejsza bowiem dotkliwość ekonomiczną pozostawania w zasobie bezrobocia i tym samym zwiększa presję na wzrost płac. Potwierdzenie tej tezy znajdujemy w równaniu (1.36a).

Wysoki stopień uzwiązkowienia i silna pozycja związków zawodowych powoduje wzrost presji płacowej i wzrost NAIRU. Z tym czynnikiem powiązana jest pozycja tzw. ,insiderów”, czyli „,swoich”. Im wyższe są ich koszty zastąpienia przez bezrobotnych, tym wyższa presja na wzrost płac i wyższa stopa bezrobocia $\mathrm{w}$ równowadze.

Wzrost udziału bezrobotnych długookresowo w zasobie bezrobocia prowadzi do wzrostu postulowanych płac realnych, co w konsekwencji prowadzi do wzrostu NAIRU. Bezrobotni długookresowo tracą bowiem część swoich kwalifikacji zawodowych i umiejętności, dlatego są stosunkowo słabymi konkurentami dla pracujących i bezrobotnych krótkookresowo w walce o miejsca pracy. Przy wyższym bezrobociu długookresowym postulaty płacowe pracujących są wyższe, co skutkuje wzrostem bezrobocia NAIRU.

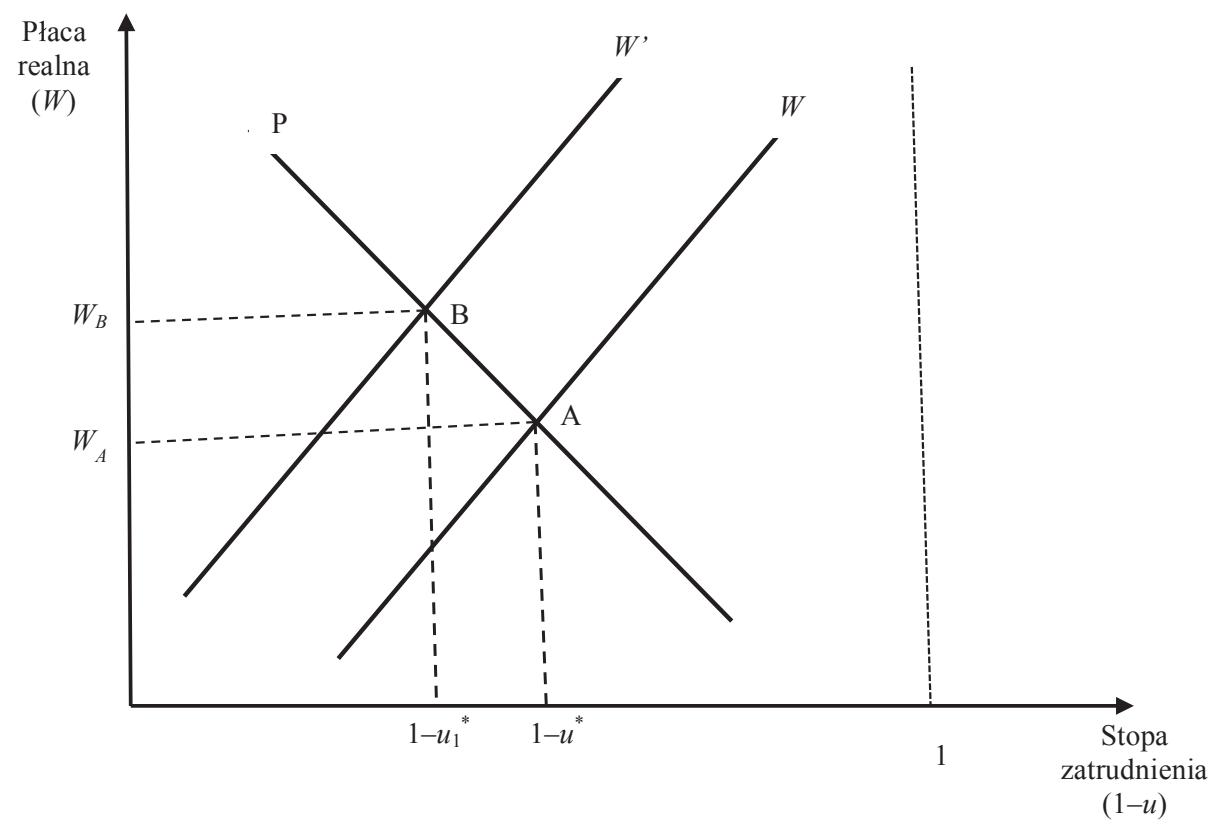

Rys. 1.6. Wpływ wzrostu presji płacowej na bezrobocie NAIRU

Źródło: opracowanie własne na podstawie: Layard, Nickell, Jackman 2005, s. 383. 
Mechanizm wpływu wzrostu presji płacowej na stopę bezrobocia NAIRU jest przedstawiony na rys. $1.6^{26}$. Przyjmijmy, że początkowo rynek pracy znajdował się $\mathrm{w}$ stanie równowagi w punkcie $\mathrm{A}$. W tym punkcie stopa zatrudnienia $\mathrm{w}$ równowadze wynosiła $\left(1-u^{*}\right)$, gdzie $u^{*}$ to stopa bezrobocia NAIRU. Wzrost presji płacowej (na skutek wzrostu udziału bezrobotnych długookresowo) przesuwa krzywą płac (postulowanych) równolegle w lewo do położenia $W^{\prime}$. W efekcie procesów dostosowawczych gospodarka przenosi się do nowego punktu równowagi na rynku pracy - B, który charakteryzuje się niższą stopą zatrudnienia w równowadze $\left(1-u_{1}^{*}\right)$, czyli tym samym wyższym poziomem stopy bezrobocia $\operatorname{NAIRU}\left(u_{1}^{*}\right)$.

Trzeba również podkreślić, że ten sam poziom bezrobocia może oznaczać odmienny poziom presji płacowej w zależności od udziału bezrobocia długookresowego.

Presja na wzrost postulowanych płac realnych zależy również od poziomu niedopasowań strukturalnych na rynku pracy (zwłaszcza w przekroju wykształcenia, zawodów i regionów (zob. Layard, Nickell, Jackman 2005, s. 285-335). Im wyższy poziom niedopasowań strukturalnych, tym wyższa presja płacowa i wyższy poziom NAIRU. Wpływ wzrostu poziomu niedopasowań strukturalnych na wysokość stopy bezrobocia NAIRU przedstawiono na rys. 1.7. Przyjmijmy, że na rynku pracy występują dwie grupy siły roboczej. Załóżmy, że krzywa płac (postulowanych) jest taka sama dla obu analizowanych grup. Jeśli obie grupy charakteryzują się takim samym poziomem stóp bezrobocia (czyli nie występują niedopasowania strukturalne), agregatowy poziom stopy bezrobocia w równowadze wyniesie $u_{A}{ }^{*}$. Na rys. 1.7 odpowiada mu punkt A. W tym punkcie przeciętna płaca realna wynosi $W_{0}$. Jeśli natomiast nastąpi zróżnicowanie stóp bezrobocia w obu grupach przy tym samym poziomie przeciętnej płacy realnej, agregatowa stopa bezrobocia w równowadze wzrośnie do poziomu $u_{B}{ }^{*}$. Wzrost niedopasowań strukturalnych podnosi więc poziom bezrobocia NAIRU.

Według przedstawicieli nowej ekonomii keynesistowskiej na poziom bezrobocia równowagi mają także pewien wpływ wahania aktywności gospodarczej. Te ostatnie oddziałują na poziom NAIRU za pośrednictwem mechanizmu histerezy bezrobocia. $\mathrm{Z}$ teorii histerezy ${ }^{27}$ wynika, że stopa bezrobocia NAIRU może wzrosnąć, jeśli faktyczna stopa bezrobocia w okresie poprzednim jest wyższa od NAIRU. Wśród mechanizmów histerezy bezrobocia warto podkreślić znaczenie ubytku kapitału ludzkiego i rolę bezrobocia długoterminowego. Osłabienie aktywności gospodarczej i wzrost bezrobocia faktycznego mogą prowadzić do znacznego ubytku kwalifikacji siły roboczej, który staje się barierą zatrudnienia w okresie poprawy koniunktury. Wzrost odsetka bezrobotnych dłu-

${ }^{26}$ Linia przerywana o współrzędnej 1 stanowi ograniczenie dla stopy zatrudnienia, która maksymalnie może wynosić $100 \%$.

${ }^{27}$ Teorie histerezy zostaną omówione szerzej w podrozdziale 1.7. 
gookresowo wzmacnia ten mechanizm. W konsekwencji następuje wzrost stopy bezrobocia NAIRU.

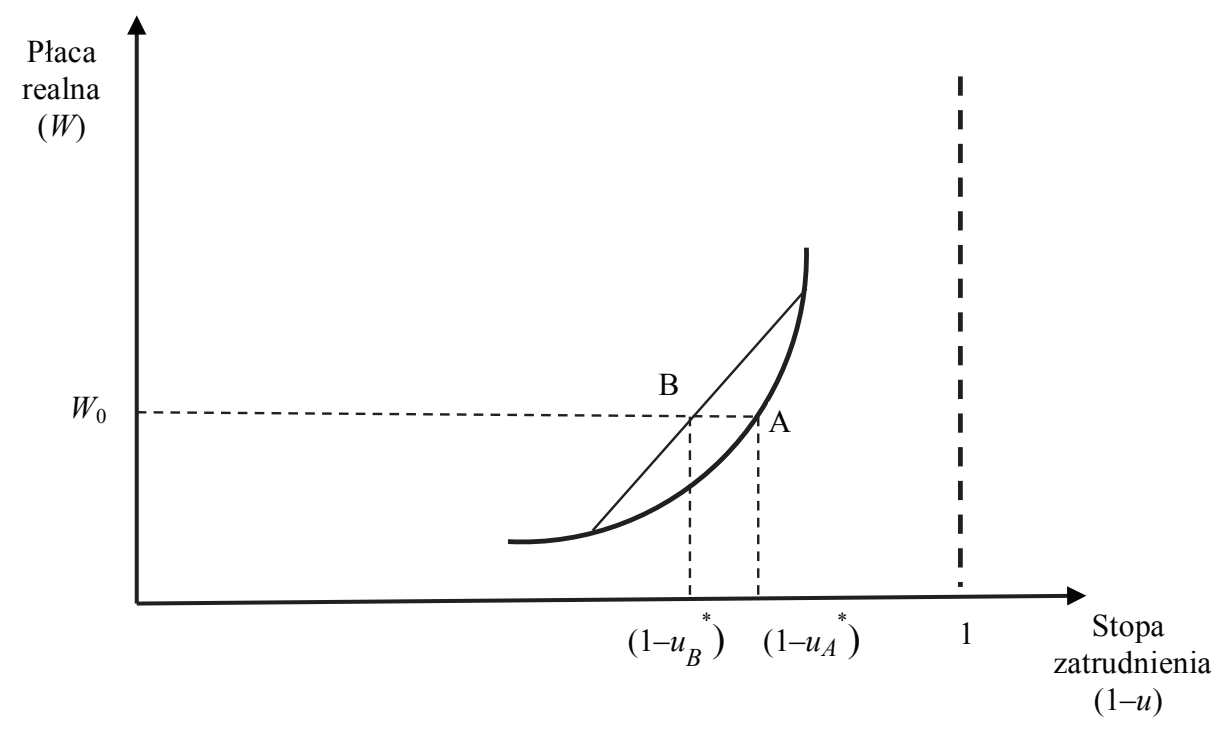

Rys. 1.7. Wpływ niedopasowań strukturalnych na poziom NAIRU

Źródło: opracowanie własne na podstawie: Layard, Nickell, Jackman 2005, s. 307.

Jak wspomniano w podrozdziale 1.1, stopa bezrobocia NAIRU jest utożsamiana z naturalną stopą bezrobocia przez niektórych ekonomistów. Do tej grupy zaliczany jest m.in. P. Minford, czołowy przedstawiciel nowej makroekonomii klasycznej (zob. Snowdon, Vane, Wynarczyk 1998, s. 246). Zarówno naturalna stopa bezrobocia, jak i stopa bezrobocia NAIRU w dhugim okresie zależą od czynników realnych ${ }^{28}$. Obie stopy bezrobocia zapewniają stabilizację procesów inflacyjnych. Trzeba jednak zwrócić uwagę, że naturalna stopa bezrobocia to stopa bezrobocia $\mathrm{w}$ warunkach równowagi na rynku pracy. Tego warunku nie spełnia stopa bezrobocia NAIRU. Ponadto, na poziom NAIRU mogą wpływać zmiany agregatowego popytu (zob. Jarmołowicz, Woźniak 2005, s. 62).

W teorii naturalnej stopy bezrobocia przyjmuje się założenie, że na rynku pracy występuje konkurencja doskonała, natomiast w teorii NAIRU rynek pracy jest rynkiem niedoskonałym.

Trzeba jednak podkreślić, że obie stopy bezrobocia są pewną miarą szeroko rozumianego bezrobocia równowagi. $\mathrm{W}$ analizach empirycznych wyznaczana

${ }^{28}$ Ze względu na występujące sztywności cen i płac na stopę bezrobocia NAIRU mogą wpływać zmiany agregatowego popytu. 
jest de facto stopa bezrobocia NAIRU. Z uwagi na to, że obie miary bezrobocia równowagi są nieobserwowalne, oszacowania NAIRU dokonywane przez poszczególnych autorów różnią się między sobą (niekiedy znacząco) (zob. Socha, Sztanderska 2000, s. 149). Nie powinno być to jednak powodem odrzucenia tej koncepcji. Jest przecież bardzo wiele wielkości ekonomicznych, które są nieobserwowalne, takie jak np. produkcja potencjalna, a które są przedmiotem analiz ekonomicznych o dużym znaczeniu.

Trudno zgodzić się z twierdzeniem wysuwanym przez niektórych ekonomistów, że z powodu dużej niedokładności oszacowań stóp bezrobocia NAIRU, ich znaczenie praktyczne jest niewielkie (zob. Bludnik 2010, s. 181-182). Oszacowania NAIRU mają bowiem istotne znaczenie dla banków centralnych. Informacja o relacji między faktyczną stopą bezrobocia a NAIRU jest wykorzystywana przy podejmowaniu decyzji odnośnie kształtowania się polityki pieniężnej.

Rozwój nowoczesnych metod ekonometrycznych pozwala na coraz większą precyzję w szacowaniu nieobserwowalnych wielkości ekonomicznych, w tym również poziomu bezrobocia równowagi.

Niektórzy ekonomiści całkowicie odrzucają koncepcję NAIRU. Przykładowo R. Eisner (1995) twierdzi, że w historii USA nigdy nie istniała stabilna relacja między inflacją a bezrobociem. Kolejnym krytykiem koncepcji NAIRU jest J. Galbraith. W swoim artykule z 1997 r. pisał on, że podstawy teoretyczne NAIRU nie są w pełni przekonujące (zob. Galbraith 1997, s. 93-108). Podnosi on również brak jednoznacznych wyników w podejmowanych próbach estymacji NAIRU. Jego zdaniem w związku z tym, że dowody empiryczne na istnienie pionowej krzywej Phillipsa są wątpliwe, to również związana z tą kwestią teza, że spadek faktycznej stopy bezrobocia poniżej NAIRU prowadzi do wzrostu inflacji, jest wątpliwa (zob. Galbraith 2002, s. 77-87). Postuluje on odrzucenie koncepcji NAIRU jako narzędzia w prowadzeniu polityki makroekonomicznej. Według niego celem polityki gospodarczej powinno być osiągnięcie i utrzymanie pełnego zatrudnienia ${ }^{29}$.

Podobnie D. Staiger, J. H. Stock, M. W. Watson (1997) uważają, że z uwagi na brak precyzji w szacowaniu NAIRU jej poziom nie powinien być wykorzystywany jako wskaźnik wyprzedzający inflacji, ponieważ inne wskaźniki są lepsze.

Odmienne zdanie odnośnie przydatności koncepcji NAIRU dla polityki makroekonomicznej ma R. J. Gordon (1996) ${ }^{30}$. Przyznaje on, że NAIRU charakteryzuje się zmiennością $\mathrm{w}$ czasie oraz wylicza szereg trudności z jej pomiarem. Według jego opinii niepewność co do wysokości NAIRU nie jest jednak tak duża, by uczynić koncepcję NAIRU bezużyteczną (zob. Gordon 1996, s. 35).

${ }^{29}$ Galbraith był zwolennikiem utrzymywania stóp procentowych przez FED na niskim poziomie (zob. Galbraith 2002, s. 87). Jak wiadomo, polityka utrzymywania niskich stóp procentowych przyczyniła się do powstania bańki spekulacyjnej na rynku mieszkaniowym w USA.

${ }^{30}$ Ten sam artykuł Gordona został opublikowany w 1997 r. w „Journal of Economics Perspectives", vol. 11. 
Pomimo problemów z dokładnością oszacowań teoria NAIRU wydaje się lepiej niż koncepcja naturalnej stopy bezrobocia opisywać procesy zachodzące na współczesnych rynkach pracy, które z całą pewnością nie są rynkami doskonałymi.

\subsection{Teoria poszukiwań ${ }^{31}$}

Teoria poszukiwań (job search theory) stanowi mikroekonomiczne ,uzupełnienie" teorii naturalnej stopy bezrobocia Friedmana i Phelpsa. Nie dotyczy ona bezpośrednio bezrobocia równowagi, jednakże bezrobocie wynikające $\mathrm{z}$ chęci poszukiwania pracy (czyli tzw. bezrobocie poszukiwań) stanowi część bezrobocia równowagi, dlatego czynniki wpływające na wielkość tego typu bezrobocia wpływają tym samym na poziom bezrobocia równowagi.

Teoria poszukiwań podejmuje próbę wyjaśnienia zasad funkcjonowania podmiotów gospodarczych w warunkach niepełnego dostępu do informacji (zob. Elliott 1990, s. 486-488). Została rozwinięta na przełomie lat 60. i 70. XX w. przez E. S. Phelpsa, D. T. Mortensena, C. C. Holta i A. A. Alchiana.

Przesłanki tej koncepcji zostały sformułowane przez G. J. Stiglera w jego dwóch artykułach z początku lat 60. (Stigler 1961; 1962). Stigler wysuwa w nich twierdzenie, że na rynkach funkcjonujących bez walrasowskiego licytatora (obwieszczającego ceny i płace) nabywcy nie znają wszystkich cen produktów oferowanych do sprzedaży przez producentów, natomiast producenci nie znają wszystkich cen produktów sprzedawanych przez swoich konkurentów. Chęć dokonywania transakcji na najkorzystniejszych warunkach skłaniać będzie nabywców i producentów do zbierania informacji poprzez penetrację rynku, która $\mathrm{w}$ istocie jest procesem poszukiwań rynkowych.

Teoria poszukiwań opiera się na następujących założeniach (zob. Holt 1970, s. 53-123). Po pierwsze, zakłada się, że miejsca pracy różnią się pod względem ofert płacowych, zaś pracownicy różnią się pod względem aspiracji płacowych. Poszczególni pracownicy są więc skłonni podjąć pracę przy różnych poziomach płacy. Ponadto należy podkreślić, że aspiracje płacowe nie są stałe, lecz ulegają zmianom w czasie. Na aspiracje płacowe pracowników mają wpływ: czas pozostawania bez pracy oraz sytuacja panująca na rynku. Wydłużanie się czasu pozostawania bez pracy prowadzić będzie do obniżania się aspiracji płacowych. W sytuacji, gdy na rynku pracy występuje wysokie bezrobocie, jednostki poszukujące pracy również obniżają swoje aspiracje płacowe. Można powiedzieć, że na rynku pracy występuje samoczynna tendencja do dopasowywania minimalnych aspiracji płacowych do struktury ofert płacowych. Po drugie, przyjmuje się założenie, że pracownicy dysponują

\footnotetext{
${ }^{31}$ Podrozdział 1.4 został oparty na opracowaniu opublikowanym w 2002 r. (zob. Kucharski 2002).
} 
niepełnymi informacjami o kształtowaniu się stawek płac oraz warunkach pracy poza ich miejscem pracy. Oczywiście jednostki w miarę swoich możliwości starają się gromadzić informacje o płacach i warunkach pracy, ale dostęp do takich informacji jest utrudniony, jeśli dana osoba pozostaje w zasobie zatrudnienia. Po trzecie, przyjmuje się, że poszukując lepiej płatnej pracy, pracownicy ponoszą pewne koszty poszukiwań (np. koszty ogłoszeń, koszty przejazdów, kontaktów z pracodawcami, utracony czas). Koszt poszukiwań jest wyższy, gdy dana jednostka pozostaje w stosunku pracy (zob. Howitt 1988; Howitt, McAfee 1987). Dodatkowo efektywniejsze jest poszukiwanie pracy, kiedy jednostka pozostaje bezrobotną niż gdy pracuje (zob. Greenwald, Stiglitz 1995, s. 220), dlatego pracujący, którzy mają wyższe aspiracje płacowe niż obecne wynagrodzenie, decydują się na pozostanie bezrobotnymi, aby móc więcej czasu poświęcić na poszukiwanie lepiej płatnej pracy. Pojawia się zatem frakcja bezrobotnych, którzy napłynęli do zasobu bezrobocia, aby móc bardziej intensywnie szukać lepiej płatnej pracy. Bezrobocie związane z poszukiwaniem pracy jest bezrobociem dobrowolnym, ponieważ wynika z optymalizacji decyzji jednostek (zob. Kwiatkowski 1988, s. 226; Romer 2000, s. 521-522; Elliott 1990, s. 487). Po czwarte, w miarę wydłużania się okresu poszukiwań wśród pracowników zanika iluzja pieniężna, a przewidywane wielkości płac nominalnych i cen dostosowują się do wielkości faktycznych. Po piąte, jednostka zdecyduje się na podjęcie poszukiwań lepiej płatnej pracy, jeśli jest przekonana, że ma duże szanse jej znalezienia. Część osób pracujących może zdecydować się na szukanie nowej pracy z powodu obaw utraty pracy (zob. Pissarides, Wadsworth 1994, s. 385-386).

W teorii poszukiwań zakłada się, że osoby poszukujące pracy podejmują decyzję o podjęciu lub odrzuceniu oferty pracy w oparciu o porównanie kosztów poszukiwań z oczekiwanymi korzyściami poszukiwań (zob. Carline, Pissarides, Siebert, Sloane 1985, s. 163). Punkt zrównania się kosztu krańcowego poszukiwania pracy z kosztem krańcowym oczekiwanych korzyści z poszukiwania pracy wyznacza płacę progową (reservation wage). Płaca progowa stanowi najniższe wynagrodzenie, za jakie jednostka gotowa jest podjąć ofertę pracy. Ze względu na zróżnicowanie aspiracji płacowych płaca progowa może przyjmować różne wartości nawet w tej samej grupie zawodowej lub też grupie osób z takim samym wykształceniem. Model „płacy progowej” jest najczęściej spotykanym wyjaśnieniem procesu poszukiwania pracy przez pracowników.

Model kształtowania się płacy progowej jest przedstawiony na rys. 1.8. Osoba mająca płacę progową $w_{R}$, odpowiadającą kwalifikacjom $(k)$, nie podejmie pracy za stawkę płac niższą od jej płacy progowej (płace na lewo od $w_{R}$ ). Jednostka ta nie ma szans na uzyskanie pracy wymagającej wyższych kwalifikacji za stawkę płac wyższą niż $w^{*}\left(k^{*}\right)$ (obszar pod krzywą na prawo od $w^{*}\left(k^{*}\right)$ ). Płaca możliwa do zaakceptowania przez nią znajduje się w przedziale $\left(w_{R} ; w^{*}\left(k^{*}\right)\right)$. Im węższy 
jest ten przedział, tym mniejsze szanse odpływu z bezrobocia. Zbyt wysokie aspiracje płacowe osób poszukujących pracy (bezrobotnych lub biernych zawodowo, chcących wrócić na rynek pracy) spowodują zmniejszenie odpływów z bezrobocia i bierności zawodowej do zatrudnienia.

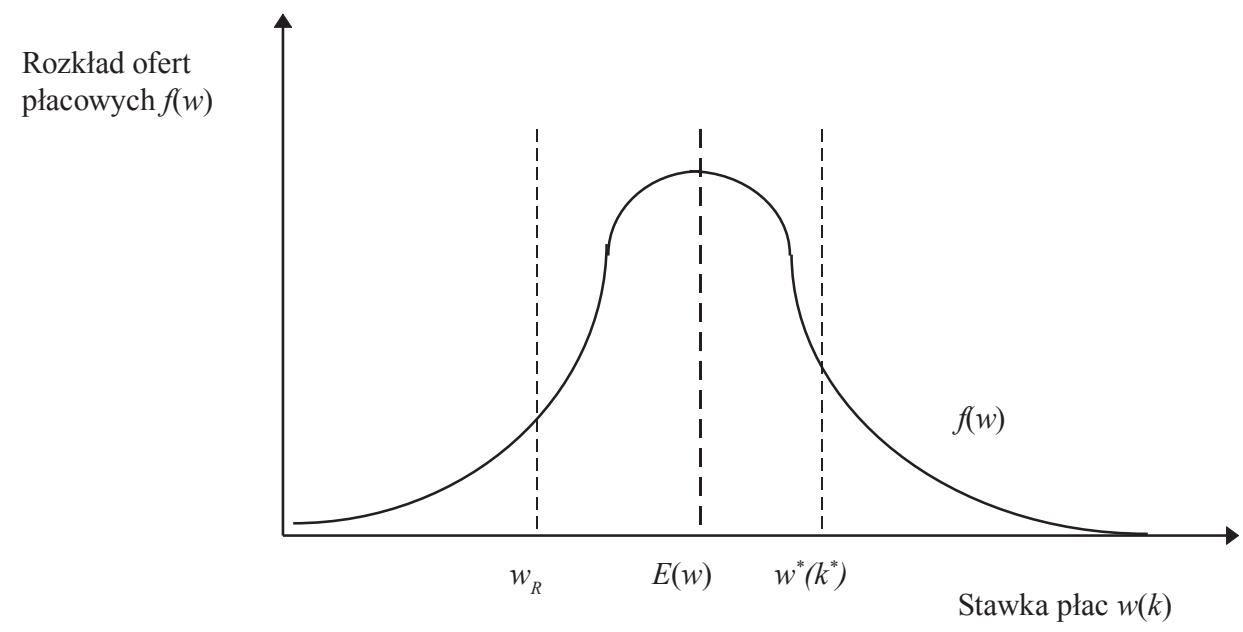

Rys. 1.8. Wybór płacy progowej w modelu poszukiwań

Źródło: Ehrenberg, Smith 1991, s. 610.

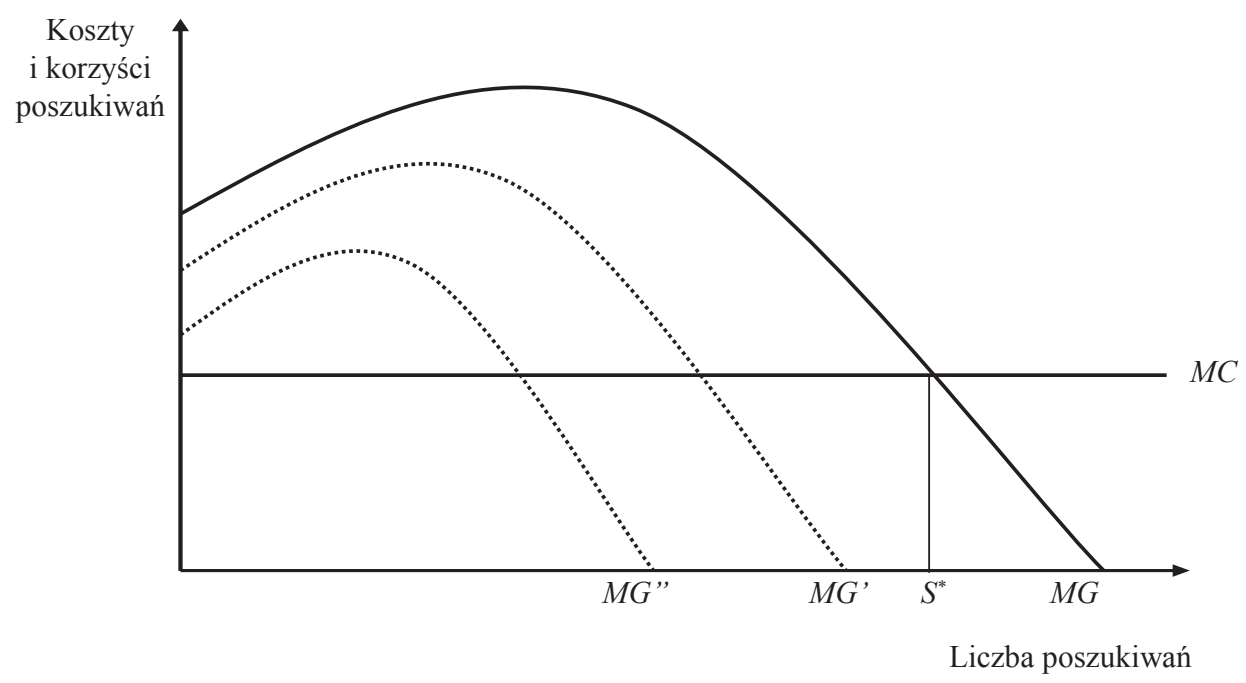

Rys. 1.9. Wybór optymalnej liczby poszukiwań pracy

Źródło: Mayhew 1983, s. 14. 
Zastanówmy się obecnie, jak długo jednostka będzie kontynuowała poszukiwania, zanim podejmie ofertę pracy. Rys. 1.9 pokazuje, jak kształtuje się liczba przeprowadzonych poszukiwań pracy w zależności od położenia krzywej krańcowych kosztów poszukiwań $(M C)$ i krańcowych korzyści poszukiwań $(M G)$. Korzyści poszukiwań to poziom ofert płacowych, jakie poznaje jednostka w trakcie procesu poszukiwania pracy. Krzywa $M C$ jest krzywą kosztu krańcowego poszukiwań (przyjmujemy, że koszt każdego następnego poszukiwania jest stały). Punkt zrównania się kosztu krańcowego z krzywą korzyści poszukiwań wyznacza optymalną liczbę rozpatrywanych ofert do momentu zaakceptowania oferty płacowej (zob. Kaźmierczak 1995, s. 106). Położenie krzywej $M G$ zależy od okresu, na jaki jednostka przewiduje, że rozpoznane oferty płacowe pozostaną trwałe. Im wyżej położona krzywa $M G$, tym dłuższy jest przewidywany przez jednostkę okres trwałości ofert płacowych. Zakładamy, że jednostka przewiduje dość długi okres trwałości ofert płacowych. Punkt $S^{*}$ wyznacza optymalną liczbę przeprowadzonych poszukiwań. Pracownik powinien zaprzestać poszukiwań, gdy osiągnie ten punkt, czyli wykorzysta wszystkie korzyści krańcowe. Jednakże na rynku pracy w dalszym ciągu pozostaną nierozpoznane oferty pracy i odpowiadający im przedział zróżnicowań płacowych. Innymi słowy, tak długo, jak koszt krańcowy będzie większy od zera, liczba przeprowadzonych poszukiwań nie będzie wystarczająca dla rozpoznania zakresu zróżnicowań płacowych. Kiedy horyzont czasowy przewidywań odnośnie ofert płacowych ulega skróceniu, punkt równowagi przesunie się do środka układu współrzędnych. Oznaczać to będzie zmniejszenie liczby poszukiwań do momentu zaakceptowania oferty pracy przez osobę poszukującą zatrudnienia.

W teorii poszukiwań zwraca się także uwagę na znaczenie efektywności poszukiwania pracy przez osoby bezrobotne. Przyjmuje się, że pojęcie efektywności poszukiwań obejmuje wszystkie czynniki przyspieszające znalezienie pracy przez osobę bezrobotną (może to być np. przepływ informacji o wolnych miejscach pracy, czas oraz intensywność poszukiwania pracy przez osoby bezrobotne, sposób rekrutacji przez pracodawców) (zob. Layard, Nickell, Jackman 1991, s. 216-218). Prawdopodobieństwo odpływu z bezrobocia zależy od efektywności poszukiwania pracy $^{32}$.

${ }^{32}$ Funkcję przyjęć do pracy można zapisać wzorem (zob. Layard, Nickell, Jackman 2005, s. 217-218):

$$
H=f(V, c U)
$$

gdzie: $H$ - liczba przyjętych do pracy, $V$ - liczba wolnych miejsc pracy, zaś $(c U)$ - liczba bezrobotnych efektywnie poszukujących pracy ( $c$ - przeciętna efektywność poszukiwań, $U$ - liczba bezrobotnych). Dzieląc obustronnie to równanie przez $U$, otrzymujemy łączną stopę odpływu z bezrobocia do zatrudnienia jako funkcję liczby wolnych miejsc pracy oraz efektywności prowadzonych poszukiwań przez osoby bezrobotne:

$$
\frac{H}{U}=c f\left(\frac{V}{c U}, 1\right)
$$


Istotne znaczenie dla intensywności poszukiwania pracy przez osoby bezrobotne ma również fakt, czy dana jednostka jest uprawniona do pobierania zasiłku lub innych świadczeń dla bezrobotnych. W literaturze ekonomicznej nie ma jednoznacznego stanowiska w tej kwestii. Niektórzy ekonomiści wskazują, że pobieranie zasiłku może skłaniać osoby bezrobotne do bardziej intensywnego poszukiwania pracy, ponieważ zasiłek zapewnia im możliwość sfinansowania ich poszukiwań (zob. Wadsworth 1991, s. 17-34; Gotschalk 1988, s. 362-365). Jednocześnie, w literaturze ekonomicznej wysuwane jest twierdzenie, że wydłużanie okresu uprawniającego do pobierania zasiłku powoduje wydłużanie okresu poszukiwań, a tym samym zwiększenie zasobu bezrobocia oraz okresu trwania bezrobocia (zob. Atkinson, Mickelwright 1989, s. 59).

M. Lindeboom i J. Theeuwes wykazali, że występuje odwrotna zależność między okresem pobierania zasiłku a prawdopodobieństwem odpływu z bezrobocia. Prawdopodobieństwo odpływu z bezrobocia wzrastało znacznie pod koniec okresu uprawniającego do pobierania zasiłku. Badania ich dotyczyły duńskiego rynku pracy (zob. Lindeboom, Theeuwes 1993, s. 341-342). Podobne wyniki uzyskali E. Kwiatkowski, Cz. Domański oraz P. Kubiak, którzy estymowali prawdopodobieństwo odpływu z bezrobocia do zatrudnienia dla osób pobierających zasiłek oraz osób niepobierających zasiłku w Polsce w latach 1994-1996. $\mathrm{Z}$ ich analiz wynika, że osoby pobierające zasiłek miały mniejsze prawdopodobieństwo odpływu z bezrobocia w okresie, w którym były uprawnione do pobierania zasiłku (zob. Kwiatkowski, Domański, Kubiak 1999, s. 333-364).

$\mathrm{Z}$ analiz przeprowadzonych przez J. Wadswortha w Wielkiej Brytanii wynika, że pobieranie zasiłku może skłaniać osoby bezrobotne do bardziej intensywnego poszukiwania zatrudnienia (zob. Wadsworth 1991, s. 17). Takie same wnioski wyciągnięto $\mathrm{z}$ badań przeprowadzonych pod kierunkiem Z. Wiśniewskiego (zob. Wiśniewski i in. 2011, s. 23).

Ważnym czynnikiem wpływającym na intensywność poszukiwań pracy przez osoby bezrobotne jest czas trwania poszukiwań. Wydłużanie się okresu trwania bezrobocia wpływa negatywnie na intensywność poszukiwań pracy. Bezrobotni długookresowo tracą motywację do poszukiwania pracy. Spadek intensywności poszukiwań wynika zarówno ze zniechęcenia, jak i z braku sukcesów w znalezieniu pracy (zob. Wojtyna 1994, s. 2-3). Efektem tego stanu może być apatia, co w konsekwencji może prowadzić do wycofania się z zasobu siły roboczej. Można zatem powiedzieć, że im dłuższy czas trwania bezrobocia, tym większe prawdopodobieństwo odpływu z bezrobocia do bierności

Można zatem powiedzieć, że prawdopodobieństwo odpływu z bezrobocia do zatrudnienia $i$-tej jednostki (poszukującej pracy z efektywnością $c_{i}$ ) można opisać wzorem:

$$
h_{i}=c_{i} f\left(\frac{V}{c U}, 1\right)
$$


zawodowej. Wydłużanie się okresu trwania bezrobocia (na skutek spadku intensywności poszukiwań) zmniejsza szanse jednostek na odpływ do zatrudnienia (zob. Layard, Nickell, Jackman 2005, s. 276; Blanchard, Diamond 1992, s. 354-359).

Na szansę znalezienia pracy wpływa wysokość płacy progowej, chociaż wraz z wydłużaniem się okresu pozostawania bez pracy płaca progowa ulega obniżeniu (zob. Christiansen 2002, s. 22). Wydłużanie się okresu trwania bezrobocia powoduje osłabienie intensywności poszukiwań (może powodować zniechęcenie i apatię wśród jednostek długo poszukujących pracy), co może skłaniać bezrobotnych do odpływu z zasobu siły roboczej.

$\mathrm{Z}$ teorii poszukiwań wynika, że na niedoskonałych rynkach pracy występuje tendencja do powstawania bezrobocia związanego z poszukiwaniem pracy, tzw. bezrobocia poszukiwań. Bezrobocie to ma charakter dobrowolny, ponieważ wynika z samodzielnych i niewymuszonych przez nikogo decyzji jednostek. Bezrobocie poszukiwań jest bezrobociem frykcyjnym, a zatem stanowi ono część bezrobocia równowagi. Wielkość tego bezrobocia zależy od szeregu czynników, do których można zaliczyć:

- stopy destrukcji oraz stopy kreacji miejsc pracy,

- intensywność poszukiwań pracy,

- jakość usług pośrednictwa pracy,

- dostęp do informacji o wolnych miejscach pracy,

- strukturę wiekową pracujących.

Im wyższa stopa destrukcji (kreacji) miejsc pracy oraz im wyższy odsetek młodych wśród pracujących, tym wyższe bezrobocie poszukiwań. Osoby młode są bardziej mobilne i częściej zmieniają miejsce pracy w odróżnieniu od starszych pracowników.

Im lepsza jakość usług pośrednictwa pracy oraz im lepszy dostęp do informacji o wolnych miejscach pracy, tym mniejsze będzie bezrobocie związane z poszukiwaniem pracy.

\subsection{Teoria bezrobocia równowagi $\mathrm{Ch}$. A. Pissaridesa}

Podstawą modeli bezrobocia równowagi opracowanych przez Pissaridesa (2012) jest teoria poszukiwań.

W podstawowym modelu bezrobocia równowagi Pissaridesa przyjmuje się następujące założenia (Pissarides 2012, s. 4-15):

- czas jest traktowany jako zmienna ciągła;

- siła robocza składa się z $L$ pracowników;

- tylko $u L$ bezrobotnych i $v L$ wolnych miejsc pracy bierze udział w procesie dopasowań ( $u$ - stopa bezrobocia, $v$ - stopa wolnych miejsc pracy); 
- liczba skojarzeń dokonywanych w danym okresie opisana jest przez funkcję dopasowań $(m-\text { liczba dopasowań })^{33}: m L=m(u L, v L)$;

- tylko osoby bezrobotne poszukują pracy;

- tylko wolne miejsca pracy mogą być oferowane przez pracodawców;

- ciasność rynku pracy, czyli: $\theta=u / v$;

- wolne miejsca pracy są znajdowane przez bezrobotnych z prawdopodobieństwem: $q(\theta)=m\left(\theta^{-1}, 1\right)$;

- prawdopodobieństwo znalezienia pracy przez bezrobotnego wynosi: $m(1, \theta)=\theta^{*} q(\theta)$

- miejsca pracy są likwidowane z powodu samoistnych szoków (zgodnie $\mathrm{z}$ rozkładem Poissona) według stopy $\lambda$ ( $\lambda$ - stopa likwidacji miejsc pracy).

W stanie równowagi na rynku pracy stopa bezrobocia jest stała, a zatem napływy do bezrobocia równają się odpływom z bezrobocia, czyli:

$$
\lambda(1-u) L d t=m L d t
$$

Lewa strona równania (1.37) to średnia liczba pracowników odpływająca $\mathrm{z}$ zatrudnienia do bezrobocia w przedziale czasu $d t$, zaś jego prawa strona to średnia liczba osób opuszczających zasób bezrobotnych (i przechodzących do zasobu pracujących). Podstawiając za $m L d t$ wyrażenie $\theta q(\theta) L d t$ (gdzie: $\theta q(\theta) d t$ to prawdopodobieństwo przepływu $\mathrm{z}$ bezrobocia do zatrudnienia) otrzymujemy:

$$
\lambda(1-u) L d t=\theta q(\theta) d t
$$

Rozwiązując równanie (1.38) względem $u$ otrzymujemy stopę bezrobocia w warunkach stanu stacjonarnego:

$$
u=\frac{\lambda}{\lambda+\theta q(\theta)}
$$

Jak wynika z równania (1.39), stopa bezrobocia w równowadze zależy od stopy likwidacji (destrukcji) miejsc pracy $(\lambda)$ oraz prawdopodobieństwa odpływu z bezrobocia do zatrudnienia $\left(q(\theta)^{*} \theta\right)$. Wzrost stopy likwidacji (destrukcji) miejsc pracy powoduje wzrost stopy bezrobocia w stanie równowagi, zaś wzrost prawdopodobieństwa odpływu z bezrobocia do zatrudnienia powoduje spadek stopy bezrobocia $\mathrm{w}$ warunkach stanu stacjonarnego.

${ }^{33}$ Zakładamy, że funkcja dopasowań jest funkcją dobrze zachowującą się, czyli jest rosnąca i wklęsła względem liczby bezrobotnych i wolnych miejsc pracy oraz jest jednorodna stopnia pierwszego (to znaczy, że charakteryzuje się stałymi efektami skali). 
W modelu Pissaridesa równowagę stacjonarną opisują trzy równania. Oprócz równania (1.39), równanie opisujące tworzenie miejsc pracy (1.40) oraz równanie płac (1.41) (zob. Pissarides 2012, s. 29):

$$
\begin{gathered}
p-w-\frac{(r+\lambda) p c}{q(\theta)} \\
w=(1-\beta) z+\beta p(1+c \theta)
\end{gathered}
$$

gdzie:

$w$ - koszt pracy,

$p$ - realna wartość produkcji wytworzonej przez jednego pracownika,

$r$ - realna stopa procentowa,

$c$ - cena wyrobów wytwarzanych przez przedsiębiorstwo,

$z$ - pozarynkowy dochód osoby bezrobotnej,

$\beta$ - miernik sily przetargowej pracy ${ }^{34}$.

Wyznaczenie poziomu kluczowych zmiennych w stanie równowagi stacjonarnej: $u$ - stopy bezrobocia, $\theta$ - współczynnika ciasności rynku pracy (czyli relacji $u / v)$ oraz $w$ (płac) wymaga rozwiązania układu trzech równań $(1.39,1.40$ oraz 1.41).

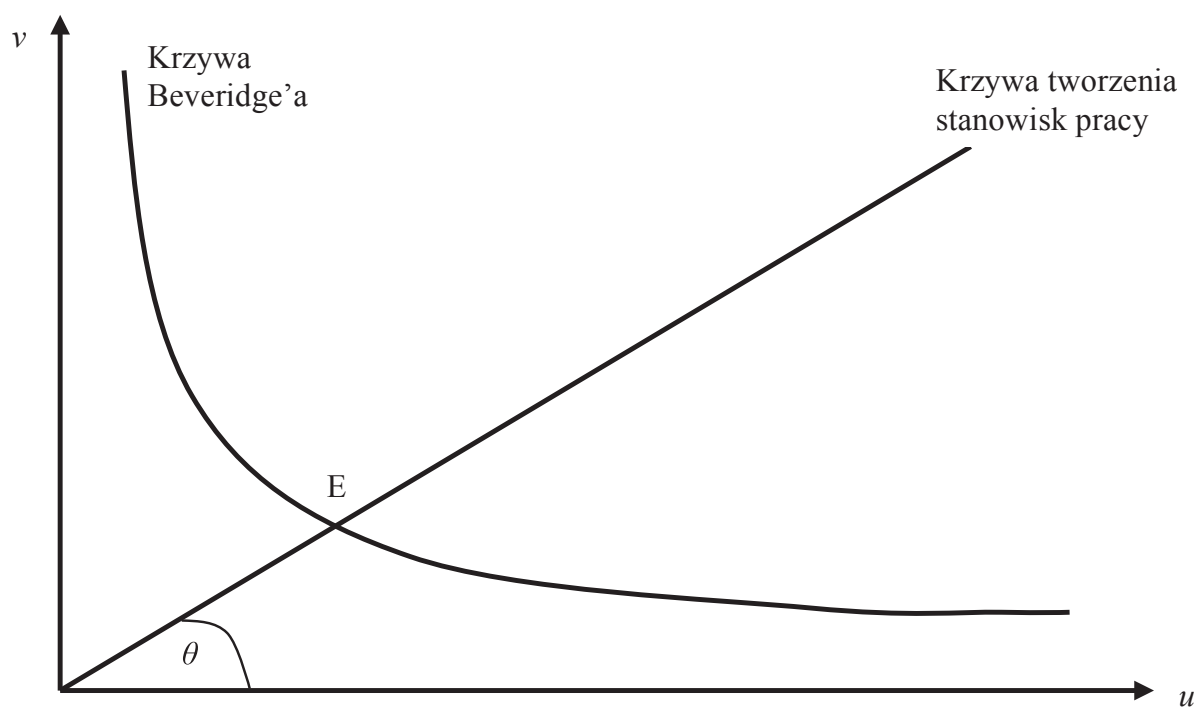

Rys. 1.10. Wolne miejsca pracy i stopa bezrobocia w stanie równowagi

Źródło: Pissarides 2012, s. 30.

${ }^{34}$ Parametr $\beta \in(0,1)$. W sytuacjach symetrycznych przyjmuje on wartość 0,5 (zob. Pissarides 2012, s. 25-26). 
Na rys. 1.10 przedstawiono ilustrację graficzną równań (1.39) oraz (1.40). Krzywa tworzenia miejsc pracy (równanie 1.40) ma nachylenie dodatnie. Oznacza to, że wraz ze wzrostem $u$ i $v$ rośnie liczba tworzonych miejsc pracy (Daly, Hobijn, Şahin, Valletta 2012, s. 152). Z kolei krzywa Beveridge'a, która stanowi ilustrację graficzną równania (1.39), ma nachylenie ujemne. Punkt przecięcia się krzywej płac z krzywą Beveridge'a wyznacza poziom stopy bezrobocia i wolnych miejsc pracy w stanie równowagi stacjonarnej.

Poziom bezrobocia w warunkach stanu stacjonarnego zależy od wszystkich czynników wpływających na położenie i nachylenie krzywych Beveridge'a oraz krzywej tworzenia stanowisk pracy. Przyjrzyjmy się, jakie czynniki i w jakim kierunku wpływają na poziom bezrobocia $\mathrm{w}$ warunkach równowagi stacjonarnej (zob. Pissarides 2012, s. 31-34). Wzrost pozarynkowych dochodów bezrobotnych, wzrost realnej stopy procentowej lub wzrost parametru $\beta$ powoduje, że krzywa tworzenia miejsc pracy staje się bardziej płaska i w konsekwencji prowadzi do wzrostu stopy bezrobocia w równowadze. Wzrost stopy likwidacji miejsc pracy przesuwa krzywą Beveridge'a w prawo, co przy danym położeniu krzywej tworzenia miejsc pracy prowadzi (jak już wskazano powyżej) do wzrostu stopy bezrobocia w warunkach stanu stacjonarnego. Na skutek wzrostu wartości produkcji wytworzonej przez jednego pracownika (czyli wydajności pracy) krzywa tworzenia miejsc pracy staje się bardziej płaska, co prowadzi do spadku bezrobocia $\mathrm{w}$ równowadze.

Model Pissaridesa stanowi bardzo interesujące ujęcie kwestii bezrobocia równowagi. Przy wysokim stopniu formalizacji prezentowanego modelu skróty myślowe oraz niejasności w wywodach autora utrudniają ich analizę.

Zastosowanie modelu Pissaridesa $w$ analizach empirycznych może być utrudnione ze względu na to, że do oszacowań stóp bezrobocia w równowadze są potrzebne dane o wolnych miejscach pracy. Dane o wolnych miejscach pracy w Polsce i innych krajach są niedoszacowane, co tym samym może wpływać na uzyskane wyniki.

\subsection{Strukturalistyczna teoria bezrobocia E. S. Phelpsa}

Strukturalistyczna teoria zmian bezrobocia została sformułowana przez Phelpsa i opublikowana przez niego po raz pierwszy w 1994 r. Przyznaje on w swojej książce, że jego teoria bezrobocia równowagi z lat 60 . ma dwie podstawowe wady (zob. Phelps 1998). Pomija ona wpływ zmiany cen i ilości na innych rynkach na równowagę na rynku pracy, czyli tym samym nie uwzględnia wpływu zagregowanych szoków na równowagę na rynku pracy. Drugą wadą jest fakt, iż przyjęte zostało założenie, że stopa bezrobocia równowagi jest długookresowym stabilnym stanem wyznaczonym przez stronę podażową. Na tej podstawie trudno jest uzasadnić trwałe utrzymywanie się kryzysu lub ożywienia w gospodarce. 
Strukturalistyczna teoria Phelpsa opisuje działanie realnych sił w gospodarce, które wywołują wahania cykliczne poprzez zmianę punktu równowagi lub zmianę naturalnej stopy bezrobocia. Zmiany podaży pieniądza powodują jedynie tymczasowe odchylenia rzeczywistego poziomu bezrobocia od naturalnej stopy bezrobocia. W strukturalistycznej teorii Phelpsa czynniki monetarne mogą nie w pełni wyjaśniać zmiany bezrobocia w długim okresie. Naturalna stopa bezrobocia jest $w$ ramach omawianej teorii strukturalistycznej definiowana przez Phelpsa jako bieżąca stała stopa bezrobocia uwzględniająca bieżące zmienne systemu gospodarczego.

Osiągnięcie równowagi na rynku pracy nie jest możliwe dopóty, dopóki rzeczywista stopa bezrobocia powoduje zmianę ścieżki stopy bezrobocia równowagi. A zatem stopa bezrobocia $w$ równowadze musi równać się naturalnej stopie bezrobocia. Phelps zakłada, że równowaga na rynku pracy ma charakter unikalny (zob. Phelps 1998, s. 33-40). Według Phelpsa przyczyn zmian poziomu bezrobocia należy upatrywać w zmianach naturalnej stopy bezrobocia, a nie odchyleń od niej na skutek błędnych przewidywań płac i cen (zob. Jarmołowicz, Woźniak 2005, s. 60).

Stopa bezrobocia w równowadze jest określana przez czynniki realne. Na poziom naturalnej stopy bezrobocia wpływają nie tylko czynniki powiązane z rynkiem pracy. Równowaga na rynku pracy zależy w znacznej mierze od zmian zachodzących na rynku dóbr i rynku kapitałowym, co stanowi istotną różnicę w porównaniu do teorii naturalnej stopy bezrobocia.

Kluczowe znaczenie w teorii Phelpsa ma pojęcie równowagi. Jego koncepcja opiera się na modelu równowagi ogólnej (zob. Godłów-Legiędź 2010, s. 123; Bludnik 2010, s. 62). Według Phelpsa „równowaga to stan lub ścieżka, na której oczekiwania są słuszne, w odpowiednim tego słowa znaczeniu, w związku z tym, wykluczając zaistnienie jakiegoś niespodziewanego wstrząsu, zostaną one spełnione i potwierdzone przez doświadczenie" (zob. Phelps 1998, s. 9). A zatem to nie bezrobocie zmienia się wokół stałej ścieżki trendu, lecz to sama ścieżka zmian bezrobocia równowagi nieustanne się przesuwa na skutek oddziaływania czynników realnych.

W odróżnieniu od teorii naturalnej stopy bezrobocia, Phelps zakłada, że na rynku pracy i rynku dóbr występuje konkurencja niedoskonała. Podmioty gospodarcze funkcjonujące na tych rynkach mają bowiem wpływ na poziom cen. Na niedoskonałym rynku pracy występuje tendencja do usztywniania płac od dołu, czyli rynek pracy się nie oczyszcza. Przy danej płacy realnej, w stanie równowagi pojawi się bezrobocie przymusowe. Na poziom płac realnych wpływa również asymetria informacji na rynku pracy.

Wprowadzenie sztywności płacy realnej w największym stopniu odróżnia teorię Phelpsa od teorii realnego cyklu koniunkturalnego. Konsekwencją tego założenia jest wyższy poziom płacy realnej i niższy poziom stopy zatrudnienia w równowadze w porównaniu do modelu konkurencji doskonałej. 
Phelps włączył do swojej teorii model płacy wydajnościowej (model rotacji pracowniczej i model bumelanta ${ }^{35}$. Wprowadzenie tych modeli miało na celu wyjaśnienie możliwości pojawiania się bezrobocia przymusowego w równowadze na rynku pracy.

Oprócz tego Phelps wprowadza do swojej teorii efekt majątkowy (zob. Phelps 1998, s. 22). Bez tego założenia wzrost wydajności spowodowałby nie tylko wzrost płacy realnej, ale także ciągły spadek naturalnej stopy bezrobocia, co wydaje się nierealistyczne w rzeczywistości gospodarczej (zob. Phelps 1998, s. 21-32). Aby stopa zatrudnienia nie wzrosła, konieczne byłoby przyjęcie pionowej krzywej równowagi płacowej. Jednakże zdaniem Phelpsa nie jest to potrzebne dzięki uwzględnieniu dochodów pozapłacowych. Dochody pozapłacowe wpływają na położenie krzywej podaży pracy ${ }^{36}$. Wzrost dochodów pozapłacowych przesuwa bowiem krzywą podaży w lewo, co tym samym niweluje pozytywny wpływ wzrostu wydajności pracy.

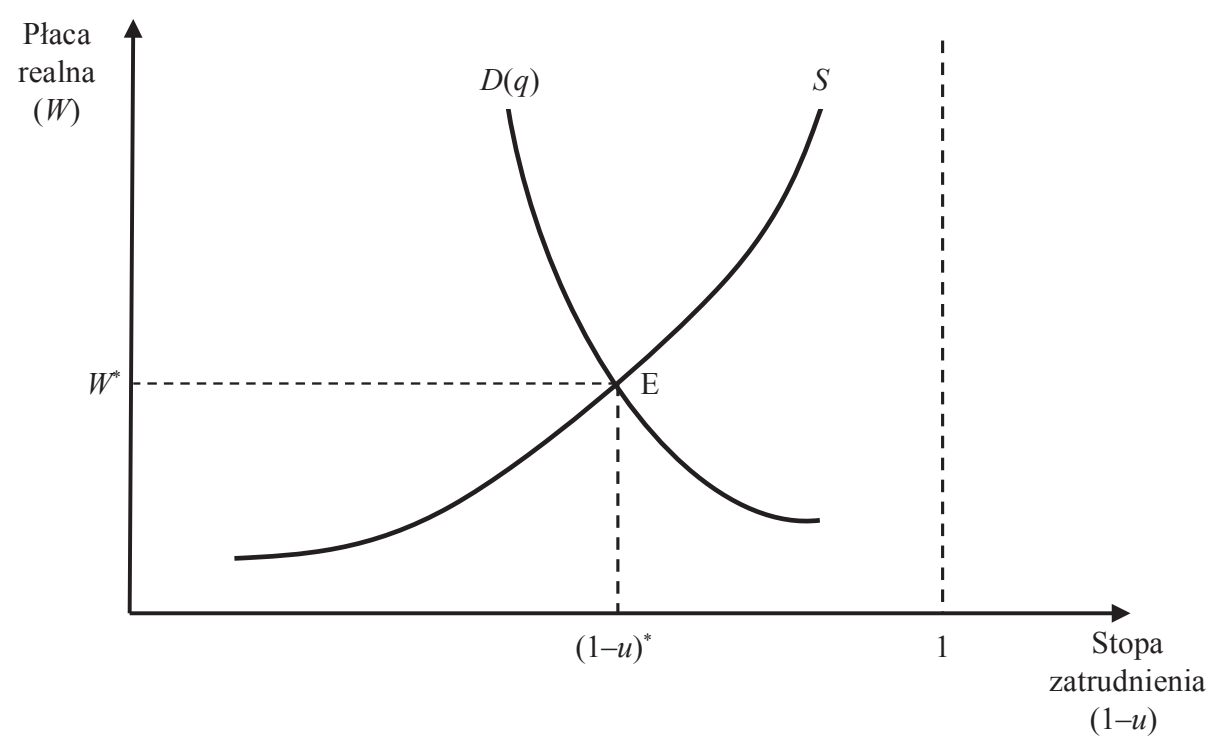

Rys. 1.11. Równowaga na rynku pracy

$S$ - krzywa równowagi płacowej (krzywa podaży pracy), $D$ - płacowa krzywa popytu (krzywa popytu na pracę).

Źródło: opracowanie własne na podstawie: Phelps 1998, s. 48.

${ }^{35} \mathrm{~W}$ modelu płacy wydajnościowej przyjmuje się założenie, że pracodawcy ustalają płace powyżej stanu równowagi, aby przeciwdziałać nadmiernej rotacji pracowników, motywować ich do wydajnej pracy, przeciwdziałać odchodzeniu z pracy specjalistów. Skutkiem tego jest pojawianie się bezrobocia przymusowego $\mathrm{w}$ stanie równowagi.

${ }^{36}$ Wprowadzenie dochodów pozapłacowych stanowi istotną zmianę w porównaniu do teorii naturalnej stopy bezrobocia. 
Ilustracją graficzną stanu równowagi na rynku pracy w ramach strukturalistycznej teorii bezrobocia jest rys. 1.11. Krzywa równowagi płacowej (krzywa podaży pracy) pokazuje stopę płacy realnej w warunkach równowagi przy danym poziomie stopy bezrobocia. Krzywa ta pokazuje takie poziomy płac realnych, przy których pracownik nie będzie zainteresowany porzuceniem pracy w celu poszukiwania lepiej płatnej pracy w innych przedsiębiorstwach.

Płacowa krzywa popytu (krzywa popytu na pracę), pokazuje zależność między płacą realną a stopą zatrudnienia, na którą zdecydują się firmy, tak by osiągnąć swój cel (zob. Van Ees, Garretsen 1996, s. 30).

Punkt przecięcia krzywej podaży pracy z krzywą popytu na pracę (płacową krzywą podaży) wyznacza równowagę na rynku pracy w strukturalistycznej teorii bezrobocia (punkt E). W stanie równowagi płaca realna wynosi $W^{*}$, natomiast stopa bezrobocia $\mathrm{w}$ równowadze $u^{*}$. Zmiana położenia krzywej podaży pracy i/lub krzywej popytu na pracę wpływa na poziom stopy bezrobocia w równowadze.

Zmiana wydajności pracy oraz wstrząsy, które wpływają na wysiłek ponoszony przez pracowników, prowadzą do zmiany położenia krzywej podaży pracy (zob. Van Ees, Garretsen 1996, s. 29). Krzywa podaży pracy przesunie się w lewo, gdy wzrosną zasiłki dla bezrobotnych, wzrosną inne płatności transferowe lub wzrosną bieżące zyski powodujące wzrost przychodów pozapłacowych. Również wzrost podatków przesunie krzywą podaży pracy w lewo.

Położenie krzywej popytu na pracę zależy od wartości (ceny) aktywów firmy $(q)$ oraz w konsekwencji od wysokości realnej stopy procentowej ${ }^{37}$. Wzrost ich wartości powoduje wzrost popytu na pracę, a zatem krzywa popytu na pracę przesunie się $\mathrm{w}$ prawo.

W celu włączenia do swojego modelu zależności pomiędzy rynkiem dóbr i rynkiem kapitałowym a popytem na pracę, Phelps wyróżnia trzy niefinansowe aktywa, w które każda firma może inwestować. Należą do nich:

- kapitał ludzki,

- kapitał w postaci długotrwałych związków z klientami,

- zasób dóbr kapitałowych.

Cechą wspólną tych trzech aktywów jest to, że zależą one od wysokości stopy zatrudnienia, ponieważ zmiana realnej wartości aktywów $(q)$ wpływa bezpośrednio na stopę zatrudnienia w równowadze.

Im wyższy jest poziom realnej wartości aktywów $(q)$ w równowadze, tym wyższa jest zdyskontowana wartość bieżąca zasobu kapitału ludzkiego, długotrwałych związków z klientami oraz zasobu dóbr kapitałowych. Wyższa wartość współczynnika $(q)$ oznacza wyższy poziom inwestycji w te aktywa oraz wyższy bieżący poziom produkcji i zatrudnienia w stanie równowagi.

Wpływ wzrostu cen aktywów na równowagę na rynku pracy przedstawiono na rys. 1.12 . Załóżmy, że początkowo równowaga na rynku pracy

\footnotetext{
${ }^{37}$ Krzywą popytu na pracę wykreśla się dla danego poziomu realnej wartości aktywów $(q)$.
} 
zachodziła w punkcie E. Wzrost realnej wartości aktywów przesuwa krzywą popytu na pracę w prawo. Gdyby krzywa podaży pracy nie zmieniła położenia, prowadziłoby to do wzrostu stopy zatrudnienia w stanie równowagi (i tym samym spadku naturalnej stopy bezrobocia) oraz wzrostu płacy realnej (tę sytuację określa punkt A na rys. 1.12). Wzrostowi płacy realnej towarzyszy jednak wzrost dochodów pozapłacowych, który powoduje przesunięcie krzywej podaży pracy w lewo ${ }^{38}$. Wzrost dochodów pozapłacowych powoduje wydłużenie okresu poszukiwania pracy.

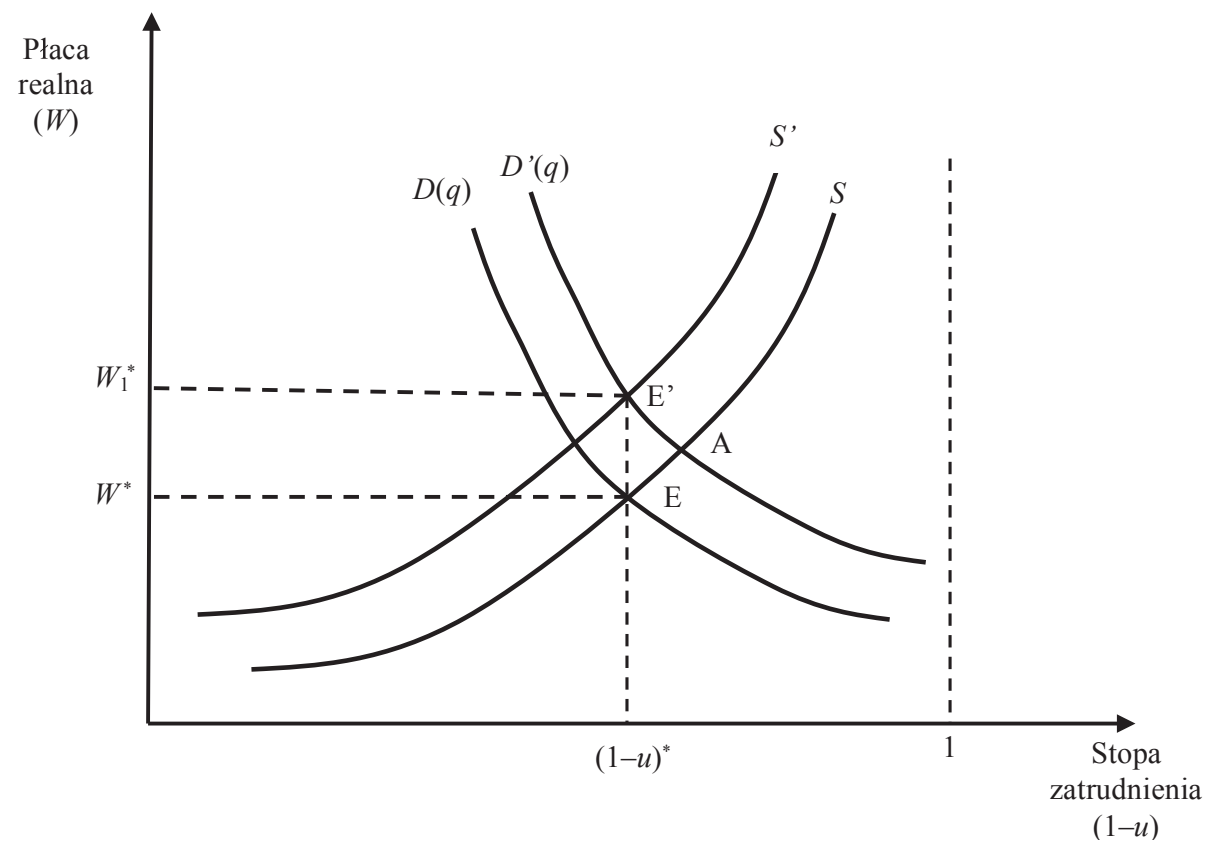

Rys. 1.12. Wpływ wzrostu cen aktywów przedsiębiorstw na naturalną stopę bezrobocia

Źródło: opracowanie własne na podstawie: Godłów-Legiędź 2010, s. 124; Van Ees, Garretsen 1996, s. 29.

W rezultacie procesów dostosowawczych nowym punktem równowagi będzie punkt E' charakteryzujący się wyższym poziomem płacy realnej oraz niezmienionym poziomem stopy zatrudnienia. Przyjmujemy, że wzrost popytu na pracę zostaje skompensowany obniżeniem podaży pracy o taką samą wartość, dlatego też stopa zatrudnienia i stopa bezrobocia w równowadze nie zmienia się. Wzrost stopy bezrobocia w równowadze nastąpiłby, jeśli żądania płacowe pracowników były wyższe od możliwego do zaakceptowania poziomu wzrostu płac przez pracodawców zgodnie z modelem płacy wydajnościowej.

${ }^{38} \mathrm{Z}$ tego powodu do modelu został wprowadzony efekt majątkowy (czyli inaczej efekt dobrobytu), o którym wspomniano powyżej. 
W teorii Phelpsa, realna stopa procentowa stanowi główny element mechanizmu transmisji pomiędzy rynkiem dóbr i rynkiem kapitałowym a rynkiem pracy. Wzrost stopy procentowej, przy innych czynnikach niezmienionych, powoduje spadek zdyskontowanej wartości bieżącej (i cen cieni) istniejących zasobów pracy, co prowadzi do spadku stopy wzrostu zatrudnienia (zob. Phelps 1998, s. 37). Można zatem powiedzieć, że zmiana realnej stopy procentowej wpływa na finansowy i niefinansowy poziom realnego majątku firmy poprzez zmianę w poziomie cen aktywów $(q)$, co wpływa tym samym na stan równowagi popytu na pracę.

Wzrost stopy procentowej zmniejsza poziom cen aktywów $(q)$, a tym samym zniechęca firmy do inwestowania w te aktywa, co z kolei zmniejsza popyt na pracę przy danej płacy realnej i w konsekwencji prowadzi do wzrostu stopy bezrobocia w równowadze.

Analizy empiryczne przeprowadzone przez Phelpsa wykazały, że głównymi przyczynami wzrostu bezrobocia w latach 70. i 80 . XX w. były: wzrost realnych stóp procentowych, wzrost prywatnego bogactwa, antymotywacyjne programy rynku pracy oraz wzrost dochodów pozapłacowych (zob. Phelps 1998, s. 311-334). W celu ograniczenia bezrobocia Phelps proponuje działania zmierzające do zwiększenia podaży pracy poprzez ograniczenie wydatków na pomoc społeczną, ograniczenie prawnej ochrony zatrudnienia oraz pomoc dla ludzi zatrudnionych w nisko płatnych zawodach (zob. Phelps 1998, s. 359-372).

Strukturalistyczna teoria bezrobocia podejmuje ważny problem utrzymywania się zróżnicowania bezrobocia w wielu krajach uprzemysłowionych. Phelps nawiązuje w swojej koncepcji do wielu szkół ekonomii: klasycznej, neoklasycznej, austriackiej i keynesowskiej (zob. Godłów-Legiędź 2010, s. 126). Jego teoria stanowi zręczną syntezę wybranych elementów różnych teorii ekonomicznych. Trudno jednak zgodzić się z twierdzeniem Phelpsa, że jego książka to nowa ogólna teoria równowagi bezrobocia.

\subsection{Teorie histerezy}

Lata 80 . XX w. charakteryzowały się bardzo silnym wzrostem stóp bezrobocia w krajach Europy Zachodniej. W latach 1980-1985 stopa bezrobocia w Wielkiej Brytanii i RFN wzrosła ponad dwukrotnie, zaś we Francji niemal dwukrotnie (zob. tab. 1.1). Co więcej, stopy bezrobocia w tych krajach w latach następnych utrzymywały się również na wysokim poziomie. W tym samym okresie nastąpił również wzrost stóp bezrobocia w USA, lecz nie był on tak silny, jak w krajach Europy Zachodniej. Tak gwałtowny wzrost bezrobocia wskazywał, że również bezrobocie równowagi (naturalna stopa bezrobocia czy też NAIRU) musiało wzrosnąć. Teza ta znalazła potwierdzenie w analizach empirycznych. Wysunięte zostały dwa sposoby wyjaśnienia tak wysokiego poziomu bezrobocia (zob. Snowdon, Vane, Wynarczyk 1998, s. 340). 
Tabela 1.1. Stopy bezrobocia w wybranych krajach Europy Zachodniej i USA w latach 1980-1985 (w \%)

\begin{tabular}{|l|c|c|c|c|c|c|c|c|c|}
\cline { 2 - 11 } \multicolumn{1}{c|}{} & 1980 & 1981 & 1982 & 1983 & 1984 & 1985 & 1986 & 1987 & 1988 \\
\hline Austria & 1,5 & 2,1 & 3,1 & 3,7 & 3,8 & 3,6 & 3,1 & 3,8 & 3,6 \\
\hline Belgia & 8,8 & 10,8 & 12,6 & 12,1 & 12,1 & 11,3 & 11,2 & 11,0 & 9,7 \\
\hline Francja & 6,3 & 7,3 & 8,1 & 8,3 & 9,7 & 10,2 & 10,4 & 10,5 & 10,0 \\
\hline Niemcy & 3,0 & 4,4 & 6,1 & 8,0 & 7,1 & 7,2 & 6,4 & 6,2 & 6,2 \\
\hline Wielka Brytania & 5,1 & 8,1 & 9,5 & 10,5 & 10,7 & 10,9 & 11,2 & 10,1 & 8,1 \\
\hline USA & 7,0 & 7,5 & 9,5 & 9,5 & 9,5 & 7,4 & 7,1 & 6,9 & 6,1 \\
\hline
\end{tabular}

Źródło: Layard, Nickell, Jackman 2005, s. 526-529.

W ramach pierwszego wysunięto wniosek, że wzrost bezrobocia w krajach Europy Zachodniej był efektem zmniejszenia elastyczności rynku pracy oraz wzrostu niedopasowań strukturalnych (zob. Solow 2002, s. 19-20). Najczęściej wymienianymi przyczynami były: wzrost siły związków zawodowych, wzrost zasiłków dla bezrobotnych, ustawodawstwo dotyczące płacy minimalnej, nadmierna regulacja obrotu gospodarczego oraz wzrost podatków. Nie wszystkie jednak wysuwane powody wzrostu bezrobocia znalazły potwierdzenie w analizach empirycznych. W Wielkiej Brytanii wystąpił wzrost bezrobocia przy jednoczesnym osłabieniu siły związków zawodowych.

W ramach drugiego sposobu próbowano wyjaśnić wzrost faktycznego bezrobocia przy jednoczesnym wzroście bezrobocia równowagi oddziaływaniem łącznego popytu na bezrobocie równowagi. W ten sposób zyskały na znaczeniu modele histerezy bezrobocia.

Pojęcie „histereza” pochodzi z języka greckiego i oznacza „nadejść później”. Związane jest przede wszystkim z naukami przyrodniczymi. Jest również znane na gruncie fizyki. W ekonomii znalazło zastosowanie na długo przed omawianym drastycznym wzrostem bezrobocia w latach 80. XX w. (zob. Arendt 2006, s. 3). Histereza oznacza, że równowaga danego systemu nie zależy tylko od sił zewnętrznych, ale również od jego własnej historii (Wojtyna 1994, s. 2).

Pojęcie to zostało zaadoptowane do nauk ekonomicznych z nauk przyrodniczych. Phelps w 1972 r. wysunął hipotezę, że stan równowagi z daną naturalną stopą bezrobocia zależy od ścieżki, po której gospodarka dochodzi do stanu równowagi. Zależność stanu równowagi od tej ścieżki nazwał histerezą.

Histereza bezrobocia oznacza, że poziom bezrobocia równowagi (tzn. naturalnej stopy bezrobocia lub NAIRU) zależy nie tylko od obecnego stanu czynników strukturalnych, ale też od wcześniejszych tendencji bezrobocia (zob. Kwiatkowski 2002a, s. 205; Snowdon, Vane, Wynarczyk 1998, s. 340). Największy 
wkład w rozwój teorii histerezy bezrobocia wnieśli: O. J. Blanchard, L. H. Summers (1986); A. Lindbeck, D. J. Snower (1986); R. Layard, S. Nickel, R. Jackamn (1991) oraz W. Carlin, D. Soskice (1990).

Faktyczny poziom bezrobocia zależy od przejściowych wstrząsów podażowych i popytowych. Pogorszenie koniunktury powoduje wzrost poziomu bezrobocia faktycznego w stosunku do występującego w tej gospodarce poziomu bezrobocia równowagi. Wydawać by się mogło, że po zakończeniu tych perturbacji, bezrobocie faktyczne powinno zmaleć do poziomu sprzed tych gospodarczych zawirowań. Jednakże w rzeczywistości tak często się nie dzieje.

Teorie histerezy thumaczą, dlaczego pomimo poprawy koniunktury bezrobocie nie obniża się do poziomu sprzed recesji. Jest to związane $\mathrm{z}$ bezrobociem równowagi. We współczesnej ekonomii coraz większą rolę przypisuje się czynnikom związanym z:

- dopasowaniem struktury popytu i podaży siły roboczej,

- ubytkiem kapitału ludzkiego,

- ubytkiem kapitału rzeczowego,

- z mobilnością siły roboczej,

- z intensywnością poszukiwań.

W okresie recesji następuje ubytek kapitału ludzkiego i rzeczowego. Powrót dobrej koniunktury nie oznacza jednak, że wszystkie osoby, które utraciły pracę, znajdą zatrudnienie. Część osób bezrobotnych z powodu dłuższego okresu pozostawania $\mathrm{w}$ zasobie bezrobotnych staje się bezrobotnymi długookresowo, co znacząco utrudnia im znalezienie pracy z uwagi na ubytek ich kwalifikacji. Trwały ubytek kapitału rzeczowego w okresie recesji również powoduje, że w okresie ożywienia gospodarczego część osób poszukujących pracy ma problemy z jej znalezieniem. Pogłębia się tym samym proces powiększania się bezrobocia równowagi.

Efekt histerezy w ujęciu formalnym można opisać w następujący sposób (zob. Snowdon, Vane, Wynarczyk 1998, s. 340):

$$
u_{N t}=u_{N t-1}+\alpha\left(u_{t-1}-u_{N t-1}\right)+b_{t}
$$

gdzie:

$\alpha \quad-$ współczynnik histerezy,

$u_{N t}$ - naturalna stopa bezrobocia (lub NAIRU) w okresie $t$,

$u_{N t-1}$ - naturalna stopa bezrobocia (lub NAIRU) w okresie $t-1$,

$u_{t-1}$ - faktyczna stopa bezrobocia w okresie $t-1$,

$b_{t} \quad$ - element pokazujący wpływ innych czynników na stopę bezrobocia równowagi (np. wysokość zasiłków dla bezrobotnych).

Z równania (1.42) wynika, że poziom bezrobocia równowagi w okresie $t$ wzrośnie (przy danym poziomie $b_{t}$ ), gdy faktyczna stopa bezrobocia w poprzednim 
okresie będzie wyższa od stopy bezrobocia w równowadze w poprzednim okresie. Współczynnik histerezy $(\alpha)$ rośnie wraz ze sztywnością płac realnych (zob. Layard, Nickell, Jackman 2005, s. 58).

Layard, Nickell i Jackman wymieniają dwa rodzaje histerezy: pełną oraz częściową, która jest utożsamiana $\mathrm{z}$ uporczywością bezrobocia. Według nich histereza pełna występuje, gdy poziom cen lub płac zależy od zmian w stopie bezrobocia lub aktywności gospodarczej. Z histerezą częściową mamy do czynienia, kiedy zarówno poziom, jak i zmiany aktywności gospodarczej czy też bezrobocia wpływają na płace i ceny (zob. Layard, Nickell, Jackman 2005, s. 336).

W literaturze ekonomicznej można znaleźć trzy modele histerezy (zob. Blanchard, Summers 1986, s. 27-29; Kwiatkowski 2002a, s. 208; Wiśniewski 2011, s. 17):

- model ubytku kapitału ludzkiego,

- model ubytku kapitału rzeczowego,

- model ,insider - outsider" 39 .

Pierwszy z wymienionych modeli został opracowany przez Layarda (1986) oraz Layarda, Nickella, Jackmana (1991). Odwołuje się do teorii kapitału ludzkiego, której czołowymi przedstawicielami są G. S. Becker, T. W. Schultz oraz J. Mincer.

Powstanie teorii kapitału ludzkiego było efektem poszukiwań przyczyn zróżnicowania płac między zatrudnionymi oraz różnego zagrożenia bezrobociem w poszczególnych grupach siły roboczej (zob. Sapsford 1981, s. 200-206). Twórcy tej teorii odrzucają założenia teorii neoklasycznej o doskonałym rynku pracy oraz homogeniczności siły roboczej (zob. Becker 1975, s. 7-8). Przyjmuje się w niej założenie, że siła robocza nie jest jednorodna, czego przejawem jest różna produkcyjność krańcowa pracowników spowodowana różnym poziomem wykształcenia, kwalifikacji zawodowych oraz umiejętności (czyli tzw. kapitału ludzkiego). Kapitał ludzki to zasób wiedzy, umiejętności, zdrowia, siły i energii witalnej, jaką dysponują ludzie. Zasób ten można powiększać poprzez inwestycje w człowieka (zob. Domański 1993, s. 35).

Zróżnicowanie zasobu kapitału ludzkiego, jakim dysponują poszczególne jednostki, jest przyczyną występowania znacznych różnic w poziomie bezrobocia i poziomie płac w poszczególnych grupach siły roboczej. Według teorii human capital zmiany zasobu kapitału ludzkiego są ważnym czynnikiem wpływającym na poziom wzrostu gospodarczego oraz głównym elementem procesu produkcyjnego w przedsiębiorstwach (zob. Becker 1975, s. 1-2). Z analiz empirycznych wynika, że jednostki bardziej wykształcone są bardziej produktywne (zob. de Koning, Gelderblom, van der Weijde 1994, s. 1-2).

${ }^{39}$ Według A. Wojtyny model „swoich” i „obcych” stanowi jedno z ważniejszych wyjaśnień efektu histerezy bezrobocia (zob. Wojtyna 2000, s. 232-235). 
Teoria ta jest $\mathrm{z}$ wielu powodów traktowana jako rozwinięcie teorii human behaviour, która jest podstawą wielu współczesnych teorii ekonomicznych (zob. Kaźmierczak 1995, s. 99). Podstawowe znaczenie ma tutaj idea homo economicus (ekonomicznego człowieka), tzn. człowieka, który w swoich działaniach kieruje się rozwagą i ekonomicznymi kalkulacjami. Celem działania „człowieka ekonomicznego" jest dążenie do maksymalizacji własnych dochodów; cel ten jest brany przez niego pod uwagę również przy podejmowaniu decyzji na rynku pracy. Można powiedzieć, ujmując rzecz nieco szerzej, że jednostki, wydając swoje pieniądze, mają na uwadze nie tylko bieżące przyjemności, ale również przyszłe zyski o charakterze pieniężnym i pozapieniężnym (zob. Blaug 1995, s. 304-305). Przyszłe zyski zależą od poziomu inwestycji w kapitał ludzki.

Teoria kapitału ludzkiego dowodzi, że zróżnicowanie dochodów wśród pracowników oraz różny stopień zagrożenia bezrobociem są rezultatem różnych poziomów wykształcenia oraz przygotowania zawodowego jednostek. Różnice w poziomie wykształcenia oraz przygotowania zawodowego wynikają bezpośrednio z decyzji jednostek o tym, czy inwestują „,w siebie”, kiedy inwestują i jaką część dochodów inwestują. G. S. Becker przedstawia istotę inwestycji w kapitał ludzki w sposób następujący:

Pewne przedsięwzięcia kształtują przyszły dobrobyt, natomiast główny kierunek innych działań wpływa na teraźniejszość. Niektóre z nich wpływają na dochód pieniężny, inne na dochód ,psychiczny”, czyli konsumpcję. Żeglarstwo jest przede wszystkim związane z poziomem konsumpcji, a doskonalenie zawodowe wpływa głównie na dochód pieniężny, natomiast studia mogą wpływać zarówno na konsumpcję, jak i dochód pieniężny. Owe oddziaływania (na konsumpcję i dochód pieniężny) dokonywać się mogą poprzez zasoby fizyczne lub przez zasoby ludzkie. W tym opracowaniu zajmiemy się działaniami, które wpływają na przyszłe dochody pieniężne i „psychiczne” poprzez wzrost zasobów tkwiących w człowieku. Działania te są nazywane „inwestycjami w kapitał ludzki”". Istnieje wiele form tego rodzaju inwestycji, np.: pobieranie nauki w szkole, podnoszenie kwalifikacji w trakcie wykonywania pracy zawodowej, ochrona zdrowia, migracje oraz zdobywanie informacji o cenach i dochodach. Różnią się one między sobą pod względem wpływu na wynagrodzenia i konsumpcję, wielkością inwestowanych kwot, wielkością uzyskiwanych efektów oraz pod względem zależności między wielkością inwestycji i uzyskiwanych efektów. Jednak wszystkie tego rodzaju inwestycje podnoszą kwalifikacje, wiedzę i w ten sposób podnoszą pieniężne lub „psychiczne" dochody (Becker 1975, s. 1).

Twórcy teorii kapitału ludzkiego twierdzą, że tak samo jak kapitał rzeczowy, zasób kapitału ludzkiego może się zarówno powiększać, jak i ulegać deprecjacji. Warunkiem wzrostu zasobu kapitału ludzkiego są odpowiednio wysokie nakłady inwestycyjne na podnoszenie poziomu wykształcenia, na szkolenia oraz podnoszenie kwalifikacji (zob. Blaug 1995, s. 303-305; Kwiatkowski 2002a, s. 209). Do zmniejszenia zasobu kapitału ludzkiego jednostek może przyczynić się pozostawanie w zasobie bezrobocia. Osoby bezrobotne wraz z wydłużaniem się czasu 
pozostawania bez pracy tracą część swoich umiejętności zawodowych i doświadczenia. Zasób kapitału ludzkiego może się również zmniejszać na skutek jego moralnego zużycia. Wiedza, tak samo jak kapitał rzeczowy, starzeje się, zwłaszcza we współczesnej gospodarce, w której mamy do czynienia z szybkim rozwojem nowych technologii.

Wpływ ubytku kapitału ludzkiego na histerezę bezrobocia można przedstawić w następujący sposób. W sytuacji negatywnego wstrząsu popytowego lub negatywnego wstrząsu podażowego część osób dotychczas pracujących traci pracę. Pogorszenie sytuacji gospodarczej zmniejsza również szansę znalezienia pracy przez osoby bezrobotne, jak również przez biernych zawodowo. Dodatkowo rozwój technologii sprawia, że zasób kapitału ludzkiego posiadany przez osoby pozostające bez pracy zmniejsza się. Pozostawanie bez pracy oraz moralne zużycie zasobu kapitału ludzkiego przez osoby pozostające bez pracy powoduje, że posiadany przez te jednostki zasób kapitału ludzkiego maleje. To z kolei zmniejsza ich szanse na znalezienie pracy. Poprawa koniunktury gospodarczej wcale nie musi spowodować spadku bezrobocia. Niski poziom kwalifikacji i umiejętności zawodowych posiadanych przez osoby bezrobotne może uniemożliwić im znalezienie pracy. Dotyczy to w szczególności bezrobotnych długookresowo. W okresie kryzysu wzrasta odsetek bezrobotnych długookresowo. Wydłużanie się okresu trwania bezrobocia powoduje przyspieszenie procesu deprecjacji kapitału ludzkiego. Zmniejsza to istotnie szanse bezrobotnych długookresowo na znalezienie pracy. Dla pracodawców bezrobotni długookresowo nie są doskonałymi substytutami bezrobotnych krótkookresowo. Takie postępowanie pracodawców wpływa również na zachowania bezrobotnych długookresowo. Bezowocne poszukiwania pracy mogą wywoływać u nich apatię oraz zmniejszać intensywność poszukiwań pracy, co wzmacnia tym samym efekt histerezy bezrobocia (zob. Kwiatkowski 2002a, s. 214).

Wzrost udziału bezrobotnych długookresowo może prowadzić do zwiększenia presji na wzrost płac. Jak wynika z koncepcji NAIRU, poziom postulowanych płac realnych jest malejącą funkcją poziomu bezrobocia. Jednakże na poziom postulowanych płac realnych wpływa również struktura zasobu bezrobotnych. Bezrobotni długookresowo mają zdecydowanie mniejsze szanse znalezienia pracy, w związku z tym nie tworzą oni efektywnej podaży pracy. Wzrost ich udziału prowadzi zatem do obniżenia efektywnej podaży pracy i tym samym zwiększenia presji płacowej, co z kolei prowadzi do wzrostu poziomu stopy bezrobocia NAIRU.

W literaturze ekonomicznej podkreśla się, że pewną słabością modeli ubytku kapitału ludzkiego w objaśnianiu histerezy bezrobocia jest fakt, iż w zasobie bezrobocia dominują osoby o niskich kwalifikacjach, a zatem ubytek kapitału ludzkiego w ich przypadku nie jest duży (zob. Wojtyna 1994, s. 3). Ponadto, wraz z wydłużaniem się okresu poszukiwania pracy maleją aspiracje płacowe, 
co częściowo kompensuje ubytek kwalifikacji. Ta krytyka wydaje się jednak nieco przesadzona. Wydłużanie się okresu trwania bezrobocia powoduje ubytek kwalifikacji wszystkich bezrobotnych, nawet tych o wysokich kwalifikacjach. Co więcej długotrwałe przebywanie w zasobie bezrobocia osób o niskich kwalifikacjach powoduje, że stają się one de facto osobami bez żadnych kwalifikacji.

W modelach ubytku kapitału rzeczowego przyczyn histerezy bezrobocia upatruje się w ubytku kapitału rzeczowego (zob. Carlin, Soskice 1990, s. 456-462). Mechanizm wpływu tego ubytku na bezrobocie równowagi jest taki sam, jak kapitału ludzkiego. Zasób kapitału ludzkiego jest w omawianych modelach traktowany jako wielkość endogeniczna (zob. Kwiatkowski, Rogut, Roszkowska 2009, s. 185). W sytuacji negatywnego wstrząsu popytowego w gospodarce zmniejsza się stopień wykorzystania istniejących mocy produkcyjnych. Maleje też zasób kapitału rzeczowego, ponieważ przedsiębiorstwa pozbywają się części niepotrzebnych maszyn i urządzeń oraz zmniejszają nakłady inwestycyjne w rozwój kapitału rzeczowego (zob. Wojtyna 1994, s. 4; Kwiatkowski, Rogut, Roszkowska 2009, s. 185). Po zakończeniu kryzysu trwały ubytek kapitału rzeczowego jest barierą dla zwiększenia zatrudnienia i ograniczenia bezrobocia.

Wydaje się, że modele ubytku kapitału rzeczowego niezbyt dobrze tłumaczą histerezę bezrobocia. Ubytek kapitału rzeczowego ma raczej charakter krótkotrwały. W gospodarkach rozwiniętych mamy bowiem do czynienia w dłuższej perspektywie ze wzrostem produktu potencjalnego, a zatem również wzrostem zasobu kapitału rzeczowego.

Model „swoich i obcych” został rozwinięty przez A. Lindbecka i D. J. Snowera $(1986,1988)$ oraz O. Blancharda i L. Summersa (1986). W tym modelu przyjmuje się założenie, że podaż pracy nie jest zasobem homogenicznym. Zasób siły roboczej składa się z dwóch grup: „,swoich” (,,insiders”) i „obcych” („,outsiders”)

${ }^{40} \mathrm{~W}$ literaturze funkcjonuje również określenie: „uczestnik” (,insider”) - „osoba postronna” („outsider”) (zob. Snowdon, Vane, Wynarczyk 1998, s. 333). We wcześniejszych modelach ,insider - outsider”, pojęcie „swoi” było utożsamiane z osobami pracującymi, natomiast pojęcie „obcy” z osobami bezrobotnymi (zob. Lindbeck, Snower 1986; Solow 1985; Elliott 1990). W późniejszych opracowaniach A. Linbeck i D. J. Snower odchodzą od tych definicji (zob. Lindbeck, Snower 1988). Oprócz ,insiderów” i „outsiderów” wyróżniali nowo zatrudnionych, czyli osoby będące w trakcie zmiany swojego statusu z ,outsidera” na ,insidera”. Z uwagi na występujące ograniczenia na rynku pracy (np. praca „w okresie próbnym”, staż, umowa o pracę na czas określony czy też specjalistyczne szkolenia) proces zmiany statusu trwa przez pewien okres.

W niektórych opracowaniach kategoria „swoich” jest definiowana jako osoby pracujące, zrzeszone w związkach zawodowych, natomiast „obcy” to osoby pracujące, lecz niezrzeszone w związkach zawodowych oraz bezrobotni (zob. Kryńska 1996, s. 134-138). Podział ten jest jednak niezbyt ostry.

Według D. Romera „insiders” to pracownicy mający pewien związek z przedsiębiorstwem w czasie negocjacji płacowych. Ich interesy są brane pod uwagę w tych negocjacjach. „Outsiders” to osoby niemające początkowo związku z przedsiębiorstwem. Mogą oni zostać przyjęci do pracy po zawarciu umowy (zob. Romer 2000, s. 505-506). 
Kryterium podziału stanowi zdolność do wywierania wpływu na przebieg (czy też efekt) rokowań płacowych (zob. Wojtyna 1994, s. 4). „Insiders” stanowią grupę doświadczonych pracowników zatrudnionych w przedsiębiorstwie bądź pozostających w innych związkach z przedsiębiorstwem, natomiast „outsiders” to osoby niemające kontaktów z przedsiębiorstwem, które mogą być w nim jednak zatrudnione w przyszłości. O ile interesy ,insiders” są przedmiotem rokowań związków zawodowych z pracodawcami, to interesy „outsiders” nie są uwzględniane w rokowaniach płacowych.

Z założeń przyjmowanych w omawianym modelu wynika, że interesy ,swoich” (,insiders”) mają silniejszy wpływ na politykę realizowaną przez związki zawodowe w trakcie negocjacji płacowych (zob. Lindbeck, Snower 1988, s. 6769). „Swoi” stanowią grupę doświadczonych oraz wykwalifikowanych pracowników. W związku z tym „obcy”, jako mniej wykwalifikowani, są dla pracodawców osobami będącymi niedoskonałymi substytutami „,swoich”. Ponadto, „swoi” dysponują siłą rynkową wynikającą z kosztów wymiany kadr (zob. Lindbeck 1992, s. 211; Saint-Paul 1995, s. 576). Przedsiębiorstwa (z powodu wysokich kosztów płynności siły roboczej oraz możliwości pogorszenia wyników finansowych na skutek przejściowego spadku wydajności pracy) wolą płacić wyższe stawki dla swoich pracowników (,,insiders”) niż ponosić koszty związane ze zwolnieniem obecnych i przyjęciem nowych pracowników („outsiders”). Siła przetargowa „,swoich” (,insiders”) jest tym silniejsza, im wyższe są koszty płynności siły roboczej (tzn. koszty przyjęć do pracy i koszty zwolnień z pracy).

Do kosztów przyjęć nowych pracowników zalicza się: koszty poszukiwania, selekcji, negocjacji płacowych oraz specjalistycznych szkoleń nowo przyjętych osób. Koszty zwolnień obejmują: wypłaty odpraw zwalnianym pracownikom oraz koszty przeprowadzenia zwolnień.

Lindbeck i Snower (1988) podkreślają, że może występować dodatkowo inny rodzaj kosztów płynności siły roboczej związany z odmową współpracy przez „swoich” z nowo przyjętymi „obcymi”. W sytuacji, gdy „outsiderzy” zgodzą się podjąć pracę za stawkę płac niższą od stawki płac obecnie pracujących, ,insiderzy" w celu uniknięcia obniżki swoich zarobków mogą nie zgodzić się na współpracę z nowo przyjętymi. Mogą również ich szykanować. W rezultacie odmowy współpracy z nowo przyjętymi dotychczasowa produkcyjność przedsiębiorstwa może znacząco się obniżyć. Przedsiębiorstwom nie opłaca się zatem przyjmować nowych pracowników oferujących chęć podjęcia pracy za niższą stawkę płac. Ponadto, odmowa współpracy czy też szykany ze strony ,insiderów” zmniejszają atrakcyjność zatrudnienia dla nowo przyjętych w danej firmie.

W większości modeli ,insider - outsider" podejmowany jest problem histerezy bezrobocia. W warunkach negatywnego szoku popytowego firmy są zmuszone ograniczyć zatrudnienie. W ten sposób część dotychczasowych „insiderów” staje się „outsiderami”. Po zakończeniu kryzysu osoby zatrudnione 
w przedsiębiorstwach (,,insiderzy”) będą zainteresowane maksymalizacją własnych korzyści (czyli wynagrodzeń). „Insiderzy” nie zgodzą się na obniżenie swoich postulatów płacowych, co umożliwiłoby powrót do pracy osobom zwolnionym z powodu kryzysu. To powoduje, że poziom bezrobocia nie zmniejsza się do stanu sprzed kryzysu. W ten sposób negatywne szoki popytowe prowadzą do wzrostu bezrobocia. Z kolei w warunkach pozytywnego szoku popytowego ,insiderzy” będą dążyć do podniesienia wynagrodzeń, co tym samym nie doprowadzi do istotnego wzrostu zatrudnienia i ograniczenia bezrobocia (zob. Tyrowicz 2011, s. 22).

Wątpliwe jest jednak, aby ta koncepcja opisywała kształtowanie się płac w całej gospodarce. W rzeczywistej gospodarce rynkowej dominują małe i średnie przedsiębiorstwa, w których raczej nie działają związki zawodowe. Ponadto nie wszystkie gałęzie gospodarki są tak samo uzwiązkowione. Siła „insiderów” nie ma więc raczej decydującego znaczenia dla powstawania efektu histerezy.

$\mathrm{Z}$ omówionych modeli histerezy bezrobocia wynikają następujące wnioski dla polityki gospodarczej. Po pierwsze, poprzez zastosowanie aktywnej polityki fiskalnej lub pieniężnej państwo może obniżyć poziom faktycznego bezrobocia, obniżając tym samym poziom bezrobocia równowagi, ponieważ zgodnie z mechanizmem histerezy bezrobocie równowagi podąża za bezrobociem faktycznym. Po drugie, w celu ograniczenia bezrobocia państwo powinno zwiększać nakłady na aktywne programy rynku pracy w celu aktywizacji bezrobotnych, a zwłaszcza bezrobotnych długookresowo. Po trzecie, z modelu ,insider - outsider” wynika, że w celu ograniczenia bezrobocia potrzebne są działania państwa zmierzające do osłabienia pozycji ,insiderów” w przedsiębiorstwach, takie jak: osłabienie pozycji związków zawodowych oraz zmniejszenie kosztów przyjęć do pracy i kosztów zwolnień z pracy.

Z teorii histerezy wynika, że bezrobocie równowagi zmienia się wraz ze zmianami koniunktury gospodarczej. Pogorszenie koniunktury gospodarczej prowadzi do wzrostu bezrobocia i na skutek ubytku kapitału rzeczowego, kapitału ludzkiego oraz siły „swoich” do wzrostu bezrobocia równowagi.

\subsection{Podsumowanie}

Twórcy koncepcji naturalnej stopy bezrobocia - Friedman i Phelps - traktują bezrobocie równowagi jako wielkość niewrażliwą na zmiany polityki makroekonomicznej. Bezrobocie równowagi zależy od czynników realnych. Zdaniem twórców teorii naturalnej stopy bezrobocia poziom bezrobocia równowagi ma znaczenie dla polityki antyinflacyjnej. Koszty walki z inflacją w postaci wzrostu bezrobocia są według nich tylko przejściowe, ponieważ w okresie długim bezrobocie powróci do swego naturalnego poziomu. 
Problem bezrobocia równowagi stał się również przedmiotem zainteresowania czołowych przedstawicieli nowej ekonomii keynesowskiej. W ramach tego kierunku powstała teoria NAIRU. Przyjmuje się w niej założenie, że rynek pracy nie jest rynkiem wolnokonkurencyjnym. Poziom NAIRU, tak samo jak poziom naturalnej stopy bezrobocia, zależy od czynników realnych. Do najważniejszych czynników wpływających na poziom bezrobocia NAIRU można zaliczyć: zmiany w strukturze siły roboczej, zmiany wydajności pracy, siłę związków zawodowych, poziom ochrony zatrudnienia, wysokość płacy minimalnej, wysokość zasiłków dla bezrobotnych i okres ich pobierania, przepływ informacji o wolnych miejscach pracy.

$\mathrm{Z}$ teorii bezrobocia równowagi Pissaridesa wynika, że stopa bezrobocia w warunkach stanu stacjonarnego jest rosnącą funkcją stopy likwidacji (destrukcji) miejsc pracy, pozarynkowych dochodów bezrobotnych, realnej stopy procentowej oraz siły przetargowej pracy, prowadzi do wzrostu stopy bezrobocia $\mathrm{w}$ równowadze. $\mathrm{Z}$ kolei wzrost prawdopodobieństwa odpływu z bezrobocia do zatrudnienia lub wzrost wydajności pracy zmniejsza poziom stopy bezrobocia w równowadze. Zwiększanie zasiłków dla bezrobotnych oraz kosztów zwolnień $\mathrm{z}$ pracy również podnosi poziom bezrobocia $\mathrm{w}$ równowadze.

W strukturalistycznej teorii bezrobocia równowagi naturalna stopa bezrobocia traktowana jest jako wielkość zmieniająca się w czasie. Zdaniem twórcy tej teorii - Phelpsa - jej wysokość zależy od czynników powiązanych z rynkiem pracy, rynkiem dóbr i rynkiem kapitałowym. Phelps postuluje zmianę nastawienia w polityce rynku pracy. Według niego w celu przeciwdziałania bezrobociu państwo powinno dążyć do aktywizacji zawodowej bezrobotnych poprzez ograniczanie hojności systemu zasiłkowego, ograniczanie prawnej ochrony zatrudnienia, ograniczanie wydatków systemu opieki społecznej oraz wspieranie finansowe osób najmniej zarabiających.

Bardzo istotny wkład w wyjaśnienie przyczyn utrzymującego się wysokiego bezrobocia wniosła teoria histerezy bezrobocia wysunięta przez nowych keynesistów. W ramach tej teorii zwraca się uwagę, że w pewnych warunkach stopa bezrobocia równowagi może podążać za faktyczną stopą bezrobocia. Przyczyn histerezy bezrobocia upatruje się w ubytku kapitału ludzkiego, ubytku kapitału rzeczowego oraz pozycji ,insiderów”. 



\section{Rozdzial 2}

\section{Bezrobocie w Polsce w latach 1995-2012 i jego determinanty}

\subsection{Wprowadzenie}

Celem tego rozdziału jest zwrócenie uwagi na te elementy i aspekty bezrobocia w Polsce, które mogą mieć znaczenie dla kształtowania się bezrobocia równowagi. Zostaną tu przedstawione tendencje zmian poziomu bezrobocia oraz bezrobocia długookresowego, zróżnicowanie stóp bezrobocia w wybranych grupach siły roboczej, przestrzenne zróżnicowanie bezrobocia oraz niedopasowania strukturalne na rynku pracy w Polsce.

$\mathrm{Z}$ analiz teoretycznych zaprezentowanych $\mathrm{w}$ rozdziale pierwszym wynika, że bezrobocie równowagi zależy od szeregu czynników, m.in. od udziału bezrobocia długookresowego oraz zróżnicowania bezrobocia w grupach siły roboczej. Ponadto na ich podstawie można stwierdzić, że wpływ bezrobocia długookresowego na bezrobocie równowagi opiera się na mechanizmie histerezy. Wydłużanie się okresu trwania bezrobocia prowadzi do ubytku kapitału ludzkiego i w konsekwencji do zmniejszenia szans na znalezienie pracy przez bezrobotnych długookresowo. Bezrobotni długookresowo z uwagi na utratę swoich kwalifikacji mają mniejsze szanse znalezienia pracy w porównaniu do bezrobotnych krótkookresowo.

Rozważania teoretyczne prowadzą też do sformułowania wniosku, że różnice w natężeniu bezrobocia między grupami siły roboczej oznaczają, że na rynku pracy występują niedopasowania strukturalne między podażą pracy i popytem na prace. Im wyższy poziom niedopasowań strukturalnych, tym wyższy poziom bezrobocia równowagi.

W rozdziale drugim szczególna uwaga zostanie więc poświęcona tym aspektom bezrobocia, które mają znaczenie dla kształtowania się bezrobocia równowagi. Wykorzystywane są dwa źródła danych o liczbie bezrobotnych, a mianowicie dane o liczbie zarejestrowanych bezrobotnych (gromadzone przez urzędy pracy) oraz dane z badań aktywności ekonomicznej ludności (BAEL) przeprowadzane przez GUS ${ }^{1}$.

${ }^{1}$ Od maja 1992 do listopada 1998 r. badania BAEL przeprowadzane były w lutym, maju, sierpniu i listopadzie każdego roku. Od I kwartału (za wyjątkiem II i III kwartału 1999 r., kiedy 
Dane o liczbie zarejestrowanych bezrobotnych pozwalają na analizę skali oraz struktury bezrobocia. Wadą tego źródła danych jest to, że dane te, z uwagi na odmienne definicje osoby bezrobotnej, nie mogą być stosowane do porównań międzynarodowych. Dane o bezrobociu rejestrowanym nie odzwierciedlają też w pełni faktycznych rozmiarów bezrobocia. Należy bowiem zwrócić uwagę, że część osób zarejestrowanych jako bezrobotne w urzędach pracy w rzeczywistości pracuje w szarej strefie. Ponadto, część osób bezrobotnych nie rejestruje się w urzędach pracy, samodzielnie poszukując nowego miejsca pracy. To źródło danych jest jednak wykorzystywane w pracy, gdyż posiada swoje walory $^{2}$. Zaletą systemu rejestracji bezrobotnych jest miesięczna częstotliwość opracowywania danych. Dane o bezrobociu rejestrowanym pozwalają na analizę sytuacji również na lokalnych rynkach pracy.

Badania aktywności ekonomicznej ludności obejmują wszystkie kategorie osób na rynku pracy oraz są przeprowadzane zgodnie ze standardami statystyki międzynarodowej, dzięki czemu mogą być wykorzystywane w porównaniach międzynarodowych. Jednak wadą tego źródła informacji o liczbie bezrobotnych jest jego obciążenie błędem próby losowej. Dane dotyczące

to nie przeprowadzono badań) badania aktywności ekonomicznej ludności są przeprowadzane co kwartał (zob. GUS 2012a, s. 13).

${ }^{2}$ Zgodnie z ustawą z dnia 20 kwietnia 2004 r. o promocji zatrudnienia i instytucjach rynku pracy, bezrobotni to osoby niezatrudnione, nieprowadzące działalności gospodarczej i niewykonujące innej pracy zarobkowej, zdolne i gotowe do podjęcia zatrudnienia w pełnym wymiarze czasu pracy obowiązującym w danej służbie lub zawodzie, zarejestrowane w powiatowym urzędzie pracy oraz poszukujące zatrudnienia lub innej pracy zarobkowej (zob. ustawa z dnia 20 kwietnia $2004 \mathrm{r}$. o promocji zatrudnienia i instytucjach rynku pracy; Dz. U. 2004, nr 99, poz. 1001, art. 2, pkt 2). Powyższa definicja dotyczy osób, które ukończyły 18 lat, a nie ukończyły 60 r. ż. w przypadku kobiet lub 65 r. ż. w przypadku mężczyzn, co wytycza przyjmowaną w Polsce dolną i górną granicę wieku produkcyjnego.

W badaniach aktywności ekonomicznej ludności przyjmuje się z kolei definicję bezrobotnego zgodną z zaleceniami Międzynarodowej Organizacji Pracy oraz Eurostat. Zgodnie z definicją przyjętą w BAEL do bezrobotnych zaliczane są osoby spełniające jednocześnie trzy warunki (zob. GUS 2012a, s. 17):

- w okresie badanego tygodnia nie były osobami pracującymi,

- aktywnie poszukiwały pracy, tzn. podjęły konkretne działania w ciągu 4 tygodni (wliczając jako ostatni tydzień - tydzień badany), aby znaleźć pracę,

- były zdolne i gotowe podjąć pracę w ciągu 2 tygodni następujących po tygodniu badanym.

Według BAEL do bezrobotnych zaliczane są również osoby nieposzukujące pracy, ponieważ miały pracę ,załatwioną” i oczekiwały na jej rozpoczęcie przez okres nie dłuższy niż 3 miesiące oraz były gotowe ją podjąć. Zgodnie z zaleceniami Eurostatu, od I kwartału 2001 r. populacja bezrobotnych została ograniczona do osób w wieku od 15 do 74 lat.

Definicja bezrobotnego przyjmowana w badaniach BAEL jest bardziej rygorystyczna z punktu widzenia możliwości wykonywania jakiejkolwiek pracy przez osoby zaliczane do grupy bezrobotnych. Wydaje się, że dane o bezrobociu z BAEL pozwalają na bardziej precyzyjne oszacowanie faktycznego bezrobocia. 
obszaru całego kraju są bardziej wiarygodne niż szacunki dla poszczególnych regionów, dlatego też informacje z badań ankietowych wykorzystuje się przy uogólnieniach dla obszaru Polski, natomiast unika się ich przy statystykach regionalnych.

Konsekwencją przyjęcia różnych definicji osoby bezrobotnej jest to, że dane o liczbie i strukturze bezrobocia według BAEL oraz w oparciu o statystyki urzędów pracy różnią się. Należy zatem dokładnie precyzować źródło danych przy przeprowadzaniu analiz bezrobocia.

\subsection{Tendencje zmian $w$ poziomie i dynamice bezrobocia}

Przejdźmy obecnie do analizy poziomu i dynamiki bezrobocia w Polsce w latach 1995-2012. Tendencje zmian bezrobocia w latach 1995-2012 przedstawiono na wykresie 2.1. Jak wynika z wykresu 2.1, w badanym okresie liczba bezrobotnych według BAEL zmieniała się w tym samym kierunku co liczba bezrobotnych zarejestrowanych w urzędach pracy. Od I kwartału 1995 r. do III kwartału 1998 r. malał zasób bezrobocia rejestrowanego, natomiast zasób bezrobotnych według BAEL zmniejszał się do II kwartału 1998 r. Przyczyn tego spadku można upatrywać m.in. w poprawie koniunktury gospodarczej ${ }^{3}$. Warto podkreślić, że w tym okresie zasób bezrobotnych według BAEL zmniejszał się nieco wolniej niż zasób bezrobocia rejestrowanego. Ponadto, do IV kwartału 1997 r. liczba bezrobotnych zarejestrowanych $\mathrm{w}$ urzędach pracy przewyższała liczbę bezrobotnych według BAEL. Silniejszy spadek zasobu bezrobocia rejestrowanego był prawdopodobnie związany z zaostrzeniem kryteriów rejestracji w urzędach pracy (zob. Socha, Sztanderska 2000, s. 97).

Od końca 1998 r. do I kwartału 2004 r. wystąpiła natomiast silna tendencja wzrostowa (z pewnymi wahaniami) liczby bezrobotnych w obu ujęciach ${ }^{4}$. Przyczyną silnego wzrostu bezrobocia w tym okresie mogło być z kolei osłabienie koniunktury gospodarczej ${ }^{5}$. Od IV kwartału 1999 aż do końca 2005 r. liczba bezrobotnych według BAEL przewyższała też liczbę bezrobotnych zarejestrowanych ${ }^{6}$.

\footnotetext{
${ }^{3}$ Stopy wzrostu PKB w latach 1996-1998 wyniosły odpowiednio: 6,2\% w 1996 r., 7,1\% w 1997 r. oraz 5\% w 1998 r. (www.stat.gov.pl).

${ }^{4}$ Najwyższy poziom bezrobocia według BAEL w tym podokresie wystąpił w I kwartale 2004 r., zaś najwyższy poziom bezrobocia rejestrowanego wystąpił w I kwartale $2003 \mathrm{r}$.

${ }^{5}$ Tempo wzrostu PKB w poszczególnych latach w analizowanym okresie kształtowało się na poziomie: 4,5\% w 1999 r., 4,3\% w 2000 r., 1,2\% w 2001 r., 1,4\% w 2002 r. oraz 3,9\% w 2003 r. (zob. www.stat.gov.pl).

${ }^{6}$ Przyczyn różnic między danymi o liczbie bezrobotnych zarejestrowanych a liczbą bezrobotnych według BAEL można upatrywać w tym, że w BAEL do bezrobotnych od 2001 r. zalicza się osoby w wieku 15-74 lata, natomiast zgodnie z ustawą z dnia 20 kwietnia 2004 r. o promocji zatrudnienia i instytucjach rynku pracy, do bezrobotnych zalicza się kobiety w wieku 18-59 lat
} 
Z wykresu 2.1 wynika, że od II kwartału 2004 r. do III kwartału 2008 r. wystąiła silna tendencja spadkowa zarówno bezrobocia rejestrowanego, jak i bezrobocia według BAEL. Tak znaczący spadek liczby bezrobotnych mógł być rezultatem poprawy koniunktury gospodarczej. W analizowanym okresie średnie tempo wzrostu PKB oscylowało w przedziale od 3,6\% (w 2005 r.) do 6,8\% (w 2007 r.). Rok 2008, pomimo światowego kryzysu finansowego, charakteryzował się wciąż wysoką dynamiką PKB na poziomie 5\%, jednakże rezultat ten był i tak niższy od wskaźników w latach 2006-2007. Do poprawy sytuacji na rynku pracy w Polsce w okresie od II kwartału 2004 r. do III kwartału 2008 r. przyczyniła się również emigracja zarobkowa Polaków, zwłaszcza od 2006 r. (zob. GUS 2012b, s. 3).

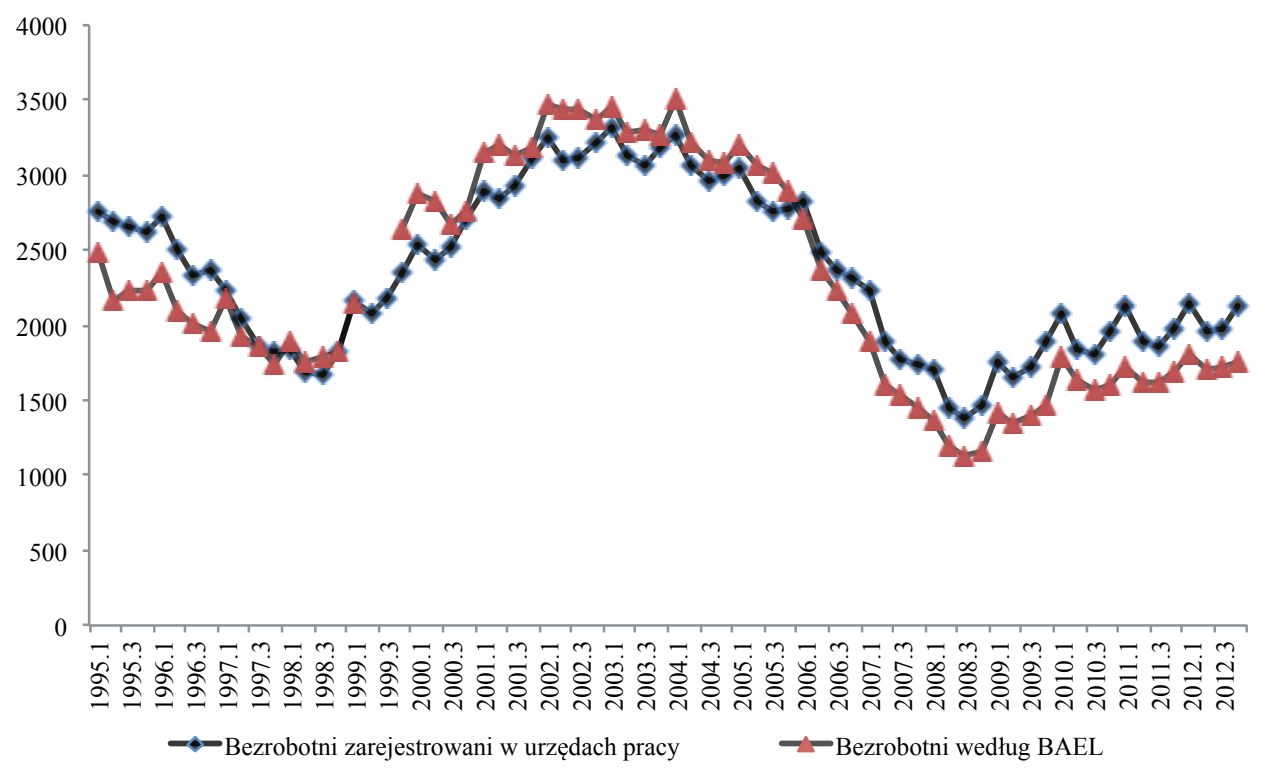

Wykres 2.1. Liczba bezrobotnych zarejestrowanych w urzędach pracy oraz według BAEL w Polsce w latach 1995-2012 (w tys. osób)

Źródło: GUS, Bezrobocie rejestrowane w Polsce, różne wydania z lat 1995-2013; GUS, Aktywność ekonomiczna ludności Polski, różne wydania z lat 1995-2013; GUS, Kwartalne wskaźniki makroekonomiczne, www.stat.gov.pl.

Od IV kwartału 2008 do IV kwartału 2012 r. wystąpiła tendencja wzrostowa (z pewnymi wahaniami sezonowymi) liczby bezrobotnych zarejestrowanych oraz według BAEL jednakże znacznie słabsza niż w okresie od IV kwartału 1998

i mężczyzn w wieku 18-64 lata. Kolejnym powodem różnic między bezrobociem rejestrowanym a BAEL może być to, że w urzędach pracy część zarejestrowanych bezrobotnych stanowią osoby pracujące w szarej strefie. Rejestrują się one w urzędach pracy w celu uzyskania prawa do bezpłatnej opieki zdrowotnej. 
do I kwartału 2004 r. Przyczyną wzrostu bezrobocia od IV kwartału 2008 r. było osłabienie koniunktury gospodarczej spowodowane światowym kryzysem finansowym. Warto również podkreślić, że od $2006 \mathrm{r}$. liczba bezrobotnych zarejestrowanych w urzędach pracy przewyższała liczbę bezrobotnych według BAEL. Od 2009 r. zasób bezrobocia rejestrowanego rósł nieco szybciej niż według BAEL, co mogło być rezultatem wzrostu zatrudnienia w szarej strefie.

Uogólniając, podkreślmy, że rozmiary bezrobocia oceniane w oparciu o oba źródła wahały się w badanym okresie wraz ze zmianami koniunktury gospodarczej. Należy jednak zauważyć, że nawet w okresach przyspieszonego wzrostu gospodarczego utrzymywał się pewien poziom bezrobocia. Można więc powiedzieć, że istnieje pewien poziom bezrobocia niewrażliwy na poprawę koniunktury gospodarczej.

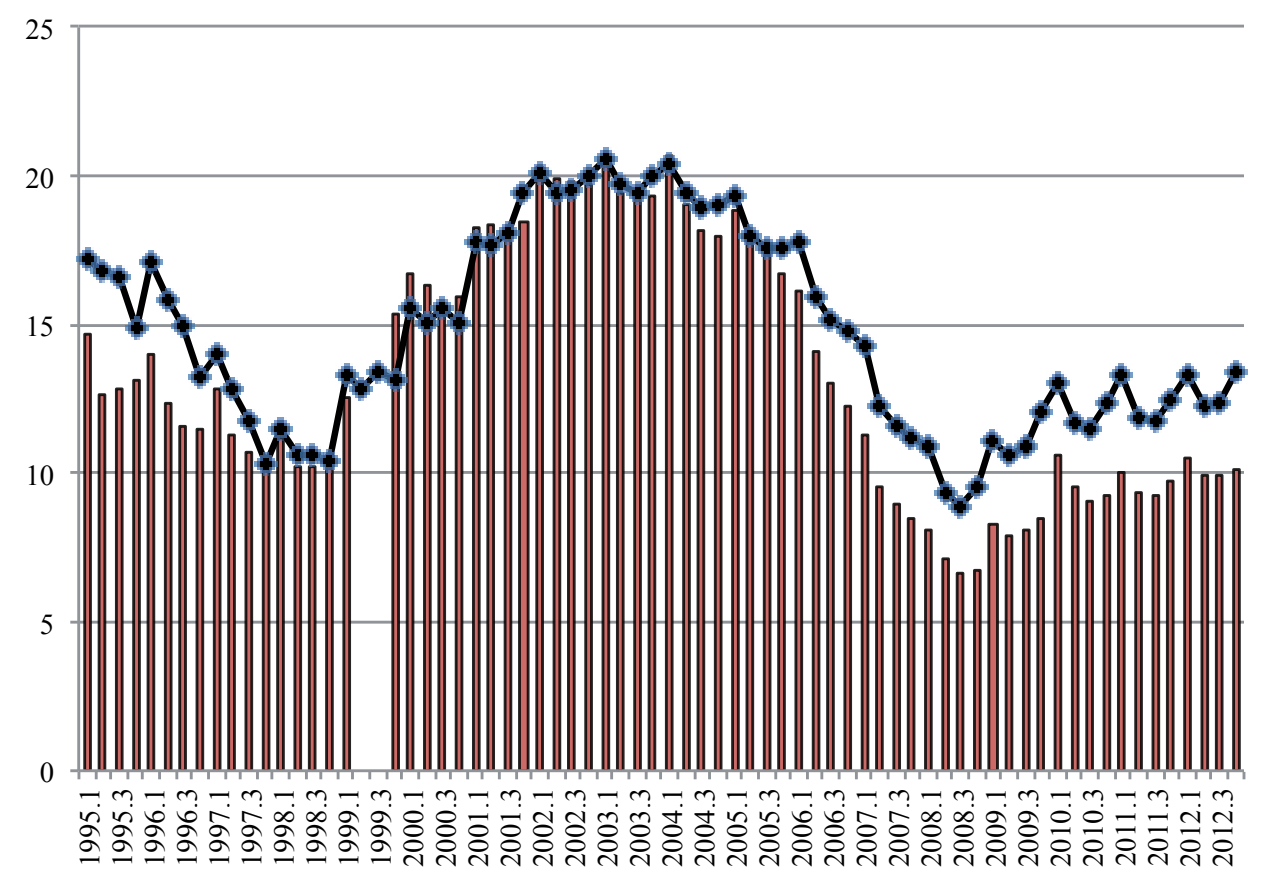

$\square$ Stopa bezrobocia według BAEL $\quad \longrightarrow$ - Stopa bezrobocia rejestrowanego

Wykres 2.2. Stopy bezrobocia rejestrowanego i według BAEL w Polsce w latach 1995-2012 (w \%)

Źródło: jak do wykresu 2.1.

Przyjrzyjmy się tendencjom zmian stóp bezrobocia rejestrowanego oraz według BAEL (zob. wykres. 2.2). Z wykresu 2.2 wynika, że w analizowanym okresie obie stopy bezrobocia charakteryzowały się zmienną tendencją. Stopa bezrobocia 
rejestrowanego charakteryzowała się tendencją spadkową w następujących podokresach: od I kwartału 1995 r. do IV kwartału 1998 r. oraz od II kwartału 2004 r. do III kwartału 2008 r. Natomiast stopa bezrobocia według BAEL malała od I kwartału 1995 r. do III kwartału 1998 r. oraz od II kwartału 2004 do III kwartału 2008 r. W pozostałych kwartałach wystąpiła tendencja wzrostowa obu stóp bezrobocia.

Należy również podkreślić, że stopy bezrobocia rejestrowanego oraz według BAEL zmieniały się w latach 1995-2012 w tych samych kierunkach, co liczba bezrobotnych (zob. wykres 2.2). Od 1998 r. do końca 2005 r. stopy bezrobocia według BAEL były zbliżone lub nieznacznie przewyższały w niektórych kwartałach stopy bezrobocia rejestrowanego. Natomiast w latach 1995-1997 i 2006-2012 stopy bezrobocia według BAEL były niższe od stóp bezrobocia rejestrowanego. Jedną z przyczyn dosyć znacznych różnic w poziomie stóp bezrobocia rejestrowanego i według BAEL po 2006 r. mogły być też wyjazdy zagraniczne Polaków. W przypadku danych BAEL ostateczne wyniki są zależne od egzogenicznych szacunków migracji, które mają wpływ na wagi, za pomocą których dokonuje się uogólnień wyników z próby. Niedoszacowanie poziomu emigracji może wynikać $\mathrm{z}$ tego, że badania BAEL nie obejmują gospodarstw domowych, które wyemigrowały w całości (zob. Gradzewicz, Strzelecki 2011, s. 71). O innych powodach różnic między danymi z BAEL i urzędów pracy wspomniano powyżej.

Ocena tendencji zmian stóp bezrobocia rejestrowanego oraz według BAEL potwierdza wnioski wynikające $\mathrm{z}$ analizy tendencji zmian samej liczby bezrobotnych. Obie stopy bezrobocia malały w okresach dobrej koniunktury oraz rosły w latach charakteryzujących się wolniejszym tempem wzrostu PKB. Z wykresów 2.1-2.2 wynika również, że pewien poziom bezrobocia występował również w okresach dobrej koniunktury, co wskazuje na to, że część bezrobocia może mieć niekoniunkturalny charakter.

\subsection{Czas trwania bezrobocia}

Z teorii histerezy wynika, że wzrost bezrobocia długookresowego prowadzi zwykle do wzrostu bezrobocia równowagi. Zasadnicze znaczenie ma tutaj argument, że bezrobotni długookresowo mają mniejsze szanse znalezienia pracy w porównaniu do bezrobotnych krótkookresowo. Wraz z wydłużaniem się okresu trwania bezrobocia następuje bowiem ubytek szeroko rozumianego kapitału ludzkiego.

$\mathrm{Na}$ wykresie 2.3 przedstawiono dane o stopach bezrobocia ogółem, stopach bezrobocia długookresowego oraz udziale bezrobotnych długookresowo w bezrobociu ogółem. Niestety dane o bezrobociu długookresowym nie są porównywalne w całym okresie. Znacznie niższy poziom obu tych wielkości (od 2008 r.) jest częściowo efektem zmiany metodologii stosowanej przez GUS w badaniach aktywności ekonomicznej ludności. Według metodologii stosowanej w BAEL od 2008 r. okres pozostawania bez pracy jest liczony od momentu zakończenia 
przerwy w poszukiwaniu pracy, o ile wystąpiła ona i trwała co najmniej 4 tygodnie (zob. GUS 2012a, s. 22). Spadek stopy bezrobocia długookresowego i udziału bezrobotnych długookresowo może więc wynikać z krótkotrwałego zaprzestania poszukiwań pracy przez te osoby. Po zakończeniu przerwy w poszukiwaniu pracy osoby pozostające bez pracy odzyskiwały status bezrobotnego, lecz ich okres pozostawania bez pracy jest liczony od nowa.

$\mathrm{Z}$ wykresu 2.3 wynika, że udział bezrobotnych długookresowo zmieniał się, z pewnym opóźnieniem w czasie, w tym samym kierunku, co stopa bezrobocia długookresowego. Co więcej, stopa bezrobocia długookresowego zachowywała się podobnie jak stopa bezrobocia ogółem. Może to wskazywać na występowanie efektu histerezy bezrobocia ${ }^{7}$.

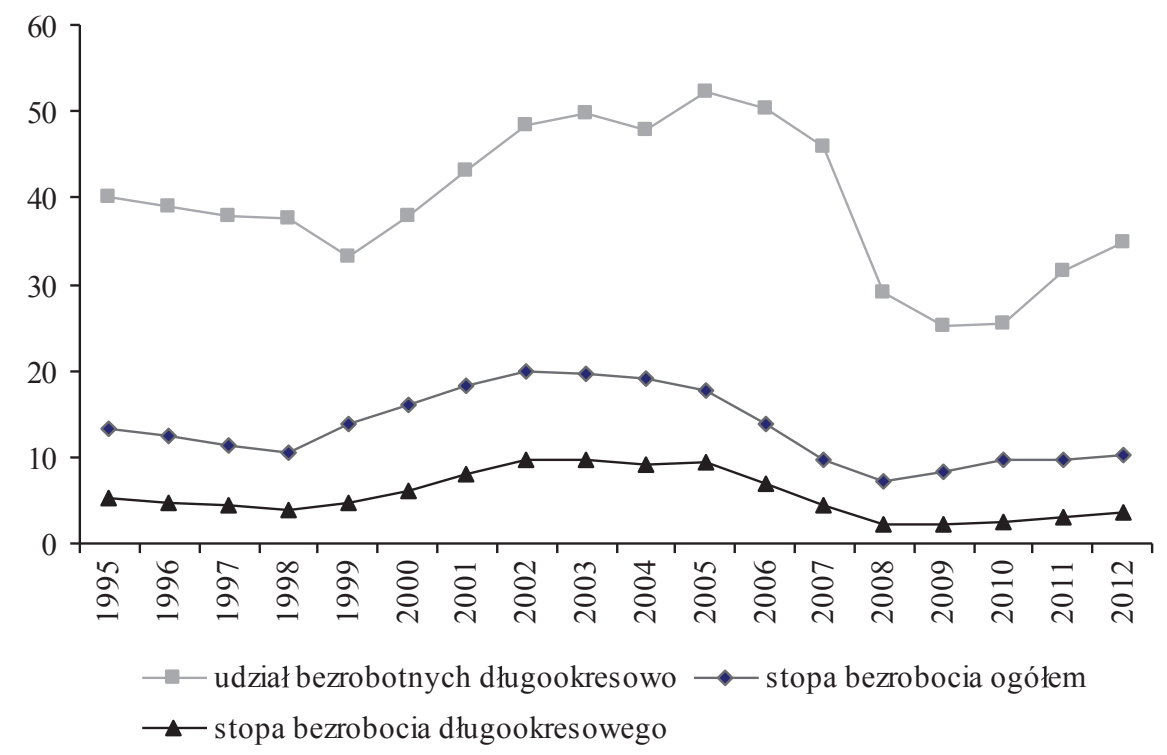

Wykres 2.3. Stopy bezrobocia ogółem i bezrobocia długookresowego oraz udział bezrobotnych długookresowo w bezrobociu ogółem w latach 1995-2012* (w \%)

* przeciętne wartości w ciągu roku.

Źródło: www.stat.gov.pl; www.psz.praca.gov.pl; GUS 2008; GUS 2013a.

${ }^{7}$ Według koncepcji histerezy skutki głębokiej recesji nie są natychmiast niwelowane przez krótkotrwałe ożywienie gospodarcze. Efektem tego stanu jest dualizacja siły roboczej na osoby pozostające bez pracy przez krótki okres i tych, którzy nie stracili pracy oraz bezrobotnych długookresowo (zob. Socha, Sztanderska 2000, s. 62-63). Z uwagi na ubytek kapitału ludzkiego spowodowany długotrwałym pozostawaniem w zasobie bezrobocia, bezrobotni długookresowo mają mniejsze szanse znalezienia pracy (Kwiatkowski 2002a, s. 153). Teorie histerezy wskazują, iż poziom bezrobocia równowagi może podążać za faktyczną stopą bezrobocia. Ponieważ bezrobocie długookresowe stanowi część bezrobocia równowagi, a zatem zmiany jego udziału w tym samym kierunku co faktyczna stopa bezrobocia mogą wskazywać na występowanie zjawiska histerezy bezrobocia. Hipoteza ta wymaga jednak odrębnych analiz. 
W okresach gorszej koniunktury wraz ze wzrostem bezrobocia ogółem rosły też stopy bezrobocia długookresowego oraz zwiększał się udział bezrobotnych długookresowo w zasobie bezrobocia ogółem. Zarazem, pomimo poprawy koniunktury w latach 2003-2005, wzrastał udział bezrobotnych długookresowo, osiągając maksymalną wartość w 2005 r. - 52,2\%. Również w 2006 r. bezrobotni długookresowo stanowili ponad 50\% bezrobotnych ogółem.

$\mathrm{Z}$ analiz empirycznych wynika, że wydłużanie się okresu trwania bezrobocia zmniejsza w istotny sposób szanse odpływu z bezrobocia (zob. Kwiatkowski, Kucharski 2009, s. 18). Bezrobotni długookresowo mieli znacznie niższe szanse odpływu $\mathrm{z}$ bezrobocia $\mathrm{w}$ badanym okresie $\mathrm{w}$ porównaniu do bezrobotnych krótkookresowo (do 6 miesięcy). Zróżnicowanie stóp odpływów z bezrobocia w poszczególnych grupach społeczno-zawodowych wskazuje jednocześnie na zróżnicowane zagrożenie bezrobociem w tych grupach. Może to wskazywać na występowanie niedopasowań strukturalnych. Ponadto, zróżnicowanie stóp odpływów w poszczególnych grupach osób bezrobotnych długookresowo dowodzi, że nie wszystkie osoby są w jednakowym stopniu zagrożone długotrwałym pozostawaniem w zasobie bezrobocia.

Wnioski płynące $\mathrm{z}$ analiz stóp odpływów w grupie bezrobotnych krótkoi długookresowo znajdują potwierdzenie w wynikach analiz ekonometrycznych prawdopodobieństwa bycia bezrobotnym długookresowo. W tab. 2.1 przedstawiono wyniki analiz ekonometrycznych w oparciu o estymację parametrów modelu logitowego (zob. Kwiatkowski, Kucharski 2009, s. 22-25).

W celu oszacowania prawdopodobieństwa bycia bezrobotnym długookresowo populację bezrobotnych podzielono na dwie kategorie: bezrobotnych długookresowo pozostających bez pracy przez okres dłuższy niż 12 miesięcy (przypisano im wartość 1) oraz bezrobotnych pozostających bez pracy przez okres do 12 miesięcy (przypisano im wartość 0$)^{8}$.

W tab. 2.1 przedstawiono oszacowania ilorazów szans (tzw. odds ratio) bycia bezrobotnym długookresowo w wybranych grupach siły roboczej w Polsce w 2006 r. Wartość stosunku szans (odds ratio) większa od 1 oznacza, że dana grupa ma większe prawdopodobieństwo bycia bezrobotnym długookresowo w porównaniu z kategorią bazową. Na przykład oszacowanie dla osób w wieku do 24 lat (kolumna 2 w tab. 2.1) wynoszące 0,457 znaczy, że osoby te miały o $54,3 \%$ mniejsze prawdopodobieństwo bycia bezrobotnymi długookresowo w porównaniu z osobami należącymi do kategorii bazowej. Zacieniowane w tabelach wartości oszacowań są na poziomie istotności 0,05 nieistotne statystycznie.

Osoby w wieku do 35 lat miały w badanym okresie mniejsze prawdopodobieństwo bycia bezrobotnymi długookresowo w porównaniu do osób w wieku

${ }^{8}$ Modele logitowe są bardzo często wykorzystywane w analizach sytuacji jednostek na rynku pracy. Więcej informacji o modelach logitowych można znaleźć np. w pracach G. C. Chowa (1995) oraz G. S. Maddali (2008). 
35-44 lata. Z kolei osoby w wieku 45-54 lata były w większym stopniu zagrożone bezrobociem długookresowym w porównaniu do kategorii bazowej.

Tabela 2.1. Oszacowania ilorazów prawdopodobieństw bycia bezrobotnym długookresowo w Polsce w 2006 r.

\begin{tabular}{|c|c|c|}
\hline Wyszczególnienie & Odds ratio & Statystyka $t$-Studenta \\
\hline \multicolumn{3}{|c|}{ Wiek (kategoria bazowa: osoby w wieku 35-44 lata) } \\
\hline do 24 lat & 0,457 & $-12,66$ \\
\hline 25-34 lata & 0,848 & $-2,98$ \\
\hline 45-54 lata & 1,180 & 3,01 \\
\hline 55 lat i więcej & 1,029 & 0,32 \\
\hline \multicolumn{3}{|c|}{ Wykształcenie (kategoria bazowa: osoby z wykształceniem zasadniczym zawodowym) } \\
\hline wyższe & 0,484 & $-9,44$ \\
\hline policealne i średnie zawodowe & 0,783 & $-5,20$ \\
\hline średnie ogólnokształcące & 0,798 & $-3,42$ \\
\hline gimnazjalne, podstawowe i niepełne podstawowe & 1,099 & 1,81 \\
\hline \multicolumn{3}{|c|}{ Poziom płacy progowej } \\
\hline do $1000 \mathrm{zł}$ & 1,190 & 4,40 \\
\hline $1001-1600 \mathrm{zl}$ & 1,025 & 0,32 \\
\hline 2001 zł i więcej & 0,798 & $-1,55$ \\
\hline \multicolumn{3}{|c|}{ Stan cywilny (kategoria bazowa: kawaler lub panna) } \\
\hline osoby zamężne (żonate) & 0,927 & $-1,74$ \\
\hline \multicolumn{3}{|c|}{ Płeć } \\
\hline mężczyźni & 0,843 & $-4,45$ \\
\hline \multicolumn{3}{|c|}{ Klasa miejscowości (kategoria bazowa: wieś) } \\
\hline miasta & 1,048 & 1,26 \\
\hline
\end{tabular}

Liczba obserwacji: 12 825; Log likelihood: $-8580,8$

Źródło: Kwiatkowski, Kucharski 2009, s. 24.

Z tab. 2.1 wynika również, że im wyższy poziom wykształcenia, tym mniejsze prawdopodobieństwo bycia bezrobotnym długookresowo. Oszacowania parametrów dla osób z najniższym poziomem wykształcenia nie są istotne statystycznie.

$\mathrm{W}$ badanym roku w większym stopniu zagrożone bezrobociem długookresowym były kobiety. Mężczyźni mieli w analizowanym okresie o 15,7\% mniejsze prawdopodobieństwo bycia bezrobotnymi długookresowo w porównaniu do kobiet. 
Tabela 2.2. Oszacowania ilorazów prawdopodobieństw bycia bezrobotnym długookresowo w Polsce w IV kwartale 2010 r.

\begin{tabular}{|c|c|c|}
\hline Wyszczególnienie & Odds ratio & Statystyka $t$-Studenta \\
\hline \multicolumn{3}{|c|}{ Wiek (kategoria bazowa: osoby w wieku 35-44 lata) } \\
\hline do 24 lat & 0,393 & $-7,88$ \\
\hline $25-34$ lata & 0,901 & $-1,00$ \\
\hline 45-54 lata & 1,585 & 4,47 \\
\hline 55 lat i więcej & 1,616 & 3,79 \\
\hline \multicolumn{3}{|c|}{ Wykształcenie (kategoria bazowa: osoby z wykształceniem zasadniczym zawodowym) } \\
\hline wyższe & 0,606 & $-4,01$ \\
\hline policealne i średnie zawodowe & 0,924 & $-0,90$ \\
\hline średnie ogólnokształcące & 0,711 & $-2,80$ \\
\hline gimnazjalne, podstawowe i niepełne podstawowe & 1,141 & 1,33 \\
\hline \multicolumn{3}{|c|}{ Stan cywilny (kategoria bazowa: kawaler lub panna) } \\
\hline osoby zamężne (żonate) & 0,857 & $-2,01$ \\
\hline \multicolumn{3}{|c|}{ Płeć } \\
\hline mężczyźni & 1,014 & 0,21 \\
\hline \multicolumn{3}{|c|}{ Klasa miejscowości (kategoria bazowa: wieś) } \\
\hline miasta & 0,938 & $-0,92$ \\
\hline
\end{tabular}

Liczba obserwacji: 4,188; Log likelihood: $-2582,59$.

Źródło: obliczenia własne na podstawie indywidualnych danych z BAEL, IV kwartał $2010 \mathrm{r}$.

Ponadto, osoby o najniższym poziomie płacy progowej były w największym stopniu zagrożone bezrobociem długookresowym. Przyczyn tego stanu można upatrywać w tym, że poziom płacy progowej jest ściśle skorelowany z poziomem kwalifikacji i stażu pracy. Osoby o najniższych kwalifikacjach mają zazwyczaj mniejsze oczekiwania płacowe.

Nieco inne wyniki w porównaniu do tych, które przedstawiono w tab. 2.1, uzyskano dla IV kwartału 2010 r. (zob. tab. 2.2). W analizie nie uwzględniono płacy progowej jako zmiennej objaśnianej. $Z$ tab. 2.2 wynika, że w najmniejszym stopniu były zagrożone bezrobociem długookresowym w porównaniu do kategorii bazowej osoby młode (w wieku do 24 lat), z wykształceniem wyższym i policealnym oraz zamężne (żonate).

W największym stopniu zagrożone bezrobociem długookresowym w tym samym okresie były osoby w wieku 55 lat i więcej. Również osoby w wieku 
45-54 lata miały wyższa prawdopodobieństwo bycia bezrobotnymi długookresowo w porównaniu do osób w wieku 35-44 lata.

Analizy przeprowadzone $\mathrm{w}$ tym podrozdziale pozwalają na wyciągnięcie wniosku, że w badanym okresie odsetek bezrobotnych długookresowo oraz stopa bezrobocia długookresowego charakteryzowały się zmienną tendencją. W latach 2001-2007 udział bezrobotnych długookresowo w bezrobociu ogółem przekraczał $40 \%$. Sugeruje to, że bezrobocie długookresowe miało istotne znaczenie dla kształtowania się bezrobocia równowagi w Polsce w badanym okresie.

\subsection{Zróżnicowanie stóp bezrobocia w wybranych grupach siły roboczej}

Mając na uwadze dotychczasowe ustalenia, przejdźmy do analizy zróżnicowania stóp bezrobocia w poszczególnych grupach siły roboczej. Dane o stopach bezrobocia w wybranych grupach siły roboczej przedstawiono w tab. 2.3.

Po pierwsze należy podkreślić, że w całym analizowanym okresie kobiety były w większym stopniu zagrożone bezrobociem niż mężczyźni. Prawidłowość ta zaznaczyła się we wszystkich latach badanego okresu. Przyczyn tego stanu można upatrywać m.in. w tym, że kobiety w większym stopniu niż mężczyźni zajmują się wychowaniem dzieci i często po ich urodzeniu całkowicie lub częściowo rezygnują z pracy zawodowej. Pracodawcy wolą zatrudniać mężczyzn, ponieważ uważają, że są oni bardziej dyspozycyjni. Należy również podkreślić, że od 2005 r. różnica między stopami bezrobocia w obu grupach uległa zmniejszeniu.

Po drugie, zauważmy, że najwyższy poziom stóp bezrobocia w latach 1995-2012 występował w grupie osób w wieku do 24 lat. Na przykład w 2002 r. stopa bezrobocia w tej grupie przekroczyła $40 \%$. Jedną z przyczyn wysokiego zagrożenia bezrobociem wśród młodzieży jest zapewne wysoka „płynność” tej grupy na rynku pracy, polegająca na częstych zmianach miejsca pracy. Czynnik ten może zniechęcać pracodawców do zatrudniania ludzi młodych z uwagi na wysokie koszty ,inwestycji” w ich kwalifikacje. Istotnym czynnikiem wpływającym na wysoki poziom bezrobocia wśród ludzi młodych w Polsce jest niedopasowanie ich kwalifikacji do potrzeb rynku pracy oraz brak doświadczenia zawodowego.

W literaturze ekonomicznej jako przyczynę wysokiego bezrobocia wśród młodzieży wymienia się również stosunkowo wysoką płacę minimalną. Potwierdzają to badania przeprowadzone w krajach OECD (zob. OECD 1998, s. 46). Jednakże określenie wpływu podnoszenia płac minimalnych na bezrobocie wśród młodzieży w Polsce wymaga odrębnych badań. 
Tabela 2.3. Stopy bezrobocia w wybranych grupach siły roboczej w latach $1995-2012^{a}$ (w \%)

\begin{tabular}{|c|c|c|c|c|c|c|c|c|}
\hline Wyszczególnienie & 1995 & 1998 & 2000 & 2002 & 2005 & 2010 & 2011 & 2012 \\
\hline Ogółem & 13,1 & 10,6 & 16,0 & 19,7 & 16,7 & 9,3 & 9,7 & 10,1 \\
\hline $\begin{array}{l}\text { Płeć: } \\
\text { mężczyźni } \\
\text { kobiety }\end{array}$ & $\begin{array}{l}12,1 \\
12,4\end{array}$ & $\begin{array}{r}9,3 \\
12,2\end{array}$ & $\begin{array}{l}14,2 \\
18,1\end{array}$ & $\begin{array}{l}19,0 \\
20,6\end{array}$ & $\begin{array}{l}15,4 \\
18,3\end{array}$ & $\begin{array}{l}8,9 \\
9,9\end{array}$ & $\begin{array}{r}8,8 \\
10,9\end{array}$ & $\begin{array}{r}9,3 \\
11,1\end{array}$ \\
\hline $\begin{array}{l}\text { Wiek: } \\
\text { do } 24 \text { lat } \\
\text { 25-34 lata } \\
\text { 35-44 lata } \\
\text { 45 lat i więcej }\end{array}$ & $\begin{array}{r}30,9 \\
13,9 \\
10,8 \\
7,1\end{array}$ & $\begin{array}{r}23,3 \\
10,6 \\
9,1 \\
6,9 \\
\end{array}$ & $\begin{array}{l}34,1 \\
16,2 \\
13,2 \\
10,7\end{array}$ & $\begin{array}{l}43,6 \\
20,0 \\
15,8 \\
13,6\end{array}$ & $\begin{array}{l}34,6 \\
16,7 \\
13,8 \\
12,8\end{array}$ & $\begin{array}{r}23,6 \\
9,6 \\
6,5 \\
7,1\end{array}$ & $\begin{array}{r}26,4 \\
10,1 \\
7,0 \\
7,1\end{array}$ & $\begin{array}{r}27,4 \\
10,7 \\
7,5 \\
7,3\end{array}$ \\
\hline $\begin{array}{l}\text { Wykształcenie: } \\
\text { wyższe } \\
\text { policealne } \\
\text { średnie zawodowe } \\
\text { średnie ogólnokształcące } \\
\text { zasadnicze zawodowe } \\
\text { gimnazjalne, podstawowe } \\
\text { i niepełne podstawowe }\end{array}$ & $\begin{array}{r}3,0 \\
9,3 \\
11,3 \\
15,3 \\
16,4 \\
14,4\end{array}$ & $\begin{array}{r}3,0 \\
8,4 \\
8,7 \\
13,5 \\
12,5 \\
14,4\end{array}$ & $\begin{array}{r}4,8 \\
12,4 \\
13,8 \\
19,6 \\
19,2 \\
\\
20,2\end{array}$ & $\begin{array}{r}7,5 \\
16,2 \\
17,6 \\
24,0 \\
23,8 \\
\\
25,4\end{array}$ & $\begin{array}{r}7,3 \\
14,8 \\
14,4 \\
21,0 \\
20,6 \\
\\
25,1\end{array}$ & $\begin{array}{r}4,7 \\
8,7 \\
9,1 \\
13,1 \\
10,5 \\
17,2\end{array}$ & $\begin{array}{c}5,2 \\
9,3^{b} \\
- \\
13,7 \\
11,3 \\
16,9\end{array}$ & $\begin{array}{c}5,7 \\
9,2^{b} \\
- \\
14,7 \\
11,9 \\
18,7\end{array}$ \\
\hline $\begin{array}{l}\text { Miejsce zamieszkania: } \\
\text { wieś } \\
\text { miasto }\end{array}$ & $\begin{array}{l}13,7 \\
12,2\end{array}$ & $\begin{array}{c}9,9 \\
11,1\end{array}$ & $\begin{array}{l}14,3 \\
16,9\end{array}$ & $\begin{array}{l}17,2 \\
21,3\end{array}$ & $\begin{array}{l}17,4 \\
15,7\end{array}$ & $\begin{array}{l}9,0 \\
9,5\end{array}$ & $\begin{array}{l}9,8 \\
9,7\end{array}$ & $\begin{array}{l}10,0 \\
10,2\end{array}$ \\
\hline
\end{tabular}

${ }^{a} \mathrm{~W}$ latach 2000-2012 stan w IV kwartale, w pozostałych latach stan w listopadzie; ${ }^{b}$ policealne i średnie zawodowe.

Źródło: GUS, Aktywność ekonomiczna ludności Polski, różne wydania z lat 1995-2013; GUS, Kwartalne wskaźniki makroekonomiczne, www.stat.gov.pl.

Po trzecie, najniższą stopą bezrobocia w badanym okresie charakteryzowały się osoby w wieku 45 lat i więcej (za wyjątkiem lat 2010-2012). Niskie natężenie bezrobocia w tej grupie wiekowej nie oznacza jednak, że grupa ta znajduje się w komfortowej sytuacji na rynku pracy. Według BAEL współczynnik aktywności zawodowej osób w wieku od 45 do 54 lat w 2011 r. wynosił 79,8, natomiast w grupie wiekowej od 55 do 59/64 lat wynosił 48\%. Dla porównania współczynnik aktywności zawodowej w grupie 35-44 lat wynosił w tym samym okresie 87,7. Tak samo w roku 2012 wystąpiły podobne relacje między współczynnikami aktywności zawodowej w tych grupach wiekowych (zob. GUS 2013a, s. 73). Niski poziom stóp bezrobocia w grupie osób w wieku powyżej 45 lat jest efektem niskiego poziomu aktywności zawodowej tej grupy, a nie niższego zagrożenia utratą pracy.

Po czwarte, biorąc pod uwagę wykształcenie, najniższe stopy bezrobocia w całym badanym okresie występowały w grupie osób z wykształceniem wyższym. Nie oznacza to jednak, że w Polsce wykształcenie wyższe chroni przed bezrobociem. Można natomiast dostrzec, że im wyższy poziom wykształcenia, tym mniejsze prawdopodobieństwo bycia bezrobotnym. Dane te potwierdzają tezę, 
że wysokie kwalifikacje mają znaczenie dla pozycji osób na rynku pracy w polskiej gospodarce. Od 1998 r. obserwujemy sukcesywny wzrost stopy bezrobocia wśród osób z wykształceniem wyższym. Szczególnie silny wzrost stopy bezrobocia w tej grupie miał miejsce w 2002 i 2005 r., a także w latach następnych.

W największym stopniu zagrożone bezrobociem były osoby z wykształceniem zasadniczym zawodowym oraz podstawowym i niepełnym podstawowym. Trudna pozycja osób o niskim poziomie wykształcenia na rynku pracy bierze się głównie stąd, iż osoby te nie są „doskonałymi substytutami” dla pracowników o wysokich kwalifikacjach. W przypadku trudności ekonomicznych w przedsiębiorstwie grupa osób o najniższych kwalifikacjach jest w pierwszej kolejności brana pod uwagę przy zwolnieniach z pracy. Jednocześnie przy przyjęciach do pracy preferowane są osoby wykształcone o wysokich kwalifikacjach (czyli wysokim zasobie kapitału ludzkiego). W latach 2005-2012 stopa bezrobocia w grupie osób z wykształceniem zasadniczym zawodowym zmalała o 8,7 punktu procentowego. Tak znaczny spadek stopy bezrobocia w tej grupie osób mógł wynikać ze wzrostu emigracji zarobkowej i braku osób z niektórymi kwalifikacjami na rynku pracy.

Po piąte, w badanym okresie stopy bezrobocia w przekroju miasto-wieś były zróżnicowane. Na początku analizowanego okresu stopy bezrobocia wśród mieszkańców wsi były wyższe niż w miastach. W kolejnych latach (od 1998 do 2005 r) to mieszkańcy miast byli w większym stopniu zagrożeni bezrobociem. Z kolei od 2005 r. stopy bezrobocia wśród mieszkańców wsi były wyższe niż w miastach. Należy zwrócić uwagę, iż na wsi w dalszym ciągu utrzymuje się nadzatrudnienie w rolnictwie (zob. Broniatowska, Gajewski, Rogut 2011, s. 41-45). Likwidacja nadzatrudnienia w rolnictwie może przyczynić się do pogłębienia bezrobocia na wsi.

Z analiz zróżnicowania stóp bezrobocia wynika, że w badanym okresie utrzymywało się dosyć silne zróżnicowanie stóp bezrobocia według wieku, wykształcenia oraz w przekroju miasto-wieś. Wysoki wskaźnik natężenia bezrobocia wśród osób młodych może być w dużej mierze przejawem ich wyższej płynności na rynku pracy. $Z$ drugiej strony może wskazywać na niedopasowanie kwalifikacji młodzieży do potrzeb rynku pracy. Natomiast silne i utrzymujące się zróżnicowanie stóp bezrobocia według wykształcenia wskazuje jednoznacznie na występowanie niedopasowań strukturalnych $\mathrm{w}$ tym przekroju na rynku pracy w Polsce.

\subsection{Przestrzenne zróżnicowanie bezrobocia}

Przestrzenne zróżnicowanie bezrobocia ma istotne znaczenie dla kształtowania się bezrobocia równowagi. Utrzymywanie się przestrzennego zróżnicowania bezrobocia wskazuje na występowanie niedopasowań strukturalnych 
na regionalnych rynkach pracy. Im wyższe jest przestrzenne zróżnicowanie stóp bezrobocia, tym wyższy poziom bezrobocia równowagi.

Jak wskazuje T. Tokarski, pomimo znacznych zmian bezrobocia ogółem po 1990 r., przestrzenne zróżnicowanie bezrobocia w Polsce ulegało tylko nieznacznemu ograniczeniu (zob. Tokarski 2008, s. 25). Z analiz przeprowadzonych przez M. Sochę i U. Sztanderską wynika z kolei, że w latach 1993-1998 nastąpił wzrost przestrzennego zróżnicowania rynku pracy (zob. Socha, Sztanderska 2000, s. 225).

Przyjrzyjmy się przestrzennemu zróżnicowaniu bezrobocia w Polsce. Z uwagi na reformę administracyjną przeprowadzoną w 1999 r. analizę ograniczono do lat 2000-2012.

W tab. 2.4 przedstawione zostały dane dotyczące zmian w poziomie bezrobocia według województw. Z ich analizy wynika, że w badanym okresie zasób bezrobotnych w poszczególnych województwach charakteryzował się dosyć zróżnicowaną dynamiką. W latach 2000-2012 nastąpił spadek poziomu bezrobocia we wszystkich województwach. Najsilniejszy spadek bezrobocia wystąpił w województwach: warmińsko-mazurskim (o 58,3\%), lubuskim (o 53,4\%) oraz dolnośląskim (o 49,6\%). Rozważając przyczyny takich tendencji, warto zauważyć, że województwo dolnośląskie należało w latach 2003-2008 do grupy województw o najwyższym poziomie konkurencyjności (zob. Kucharski, Kwiatkowski 2011, s. 17). Natomiast znaczny spadek bezrobocia w województwach warmińsko-mazurskim i lubuskim można tłumaczyć szybkim wzrostem zagranicznej emigracji zarobkowej z tych regionów.

Najmniejszy spadek bezrobocia w latach 2000-2012 wystąpił w województwach: podkarpackim (o 12,6\%), małopolskim (o 17,9\%) oraz świętokrzyskim (o $21 \%$ ). Są to regiony charakteryzujące się wysokim udziałem sektora rolniczego oraz relatywnie niskim udziałem sektora usług.

$\mathrm{Z}$ danych zawartych w tab. 2.4 wynika, że wahania koniunktury gospodarczej wpływały w różnym stopniu na dynamikę zasobu bezrobocia w poszczególnych województwach.

$\mathrm{Z}$ tab. 2.5 wynika, że w analizowanym okresie występowało znaczne zróżnicowanie stóp bezrobocia według województw. Trzeba jednak podkreślić, że w latach 2000-2007 wystąpił znaczny spadek zróżnicowania stóp bezrobocia w przekroju województw. Tendencja ta została powstrzymana w kolejnych latach (za wyjątkiem 2011 r., w którym prawie wszystkie wskaźniki zróżnicowania były niższe w porównaniu do 2007 r.). W 2012 r., w porównaniu do 2000 r., różnica między najwyższą i najniższą stopą bezrobocia $\mathrm{w}$ województwach zmniejszyła się aż o 7 punktów procentowych. $\mathrm{Z}$ tab. 2.5 można także odczytać, że najsilniejszy spadek regionalnego zróżnicowania bezrobocia w Polsce wystąpił po $2004 \mathrm{r}$. 


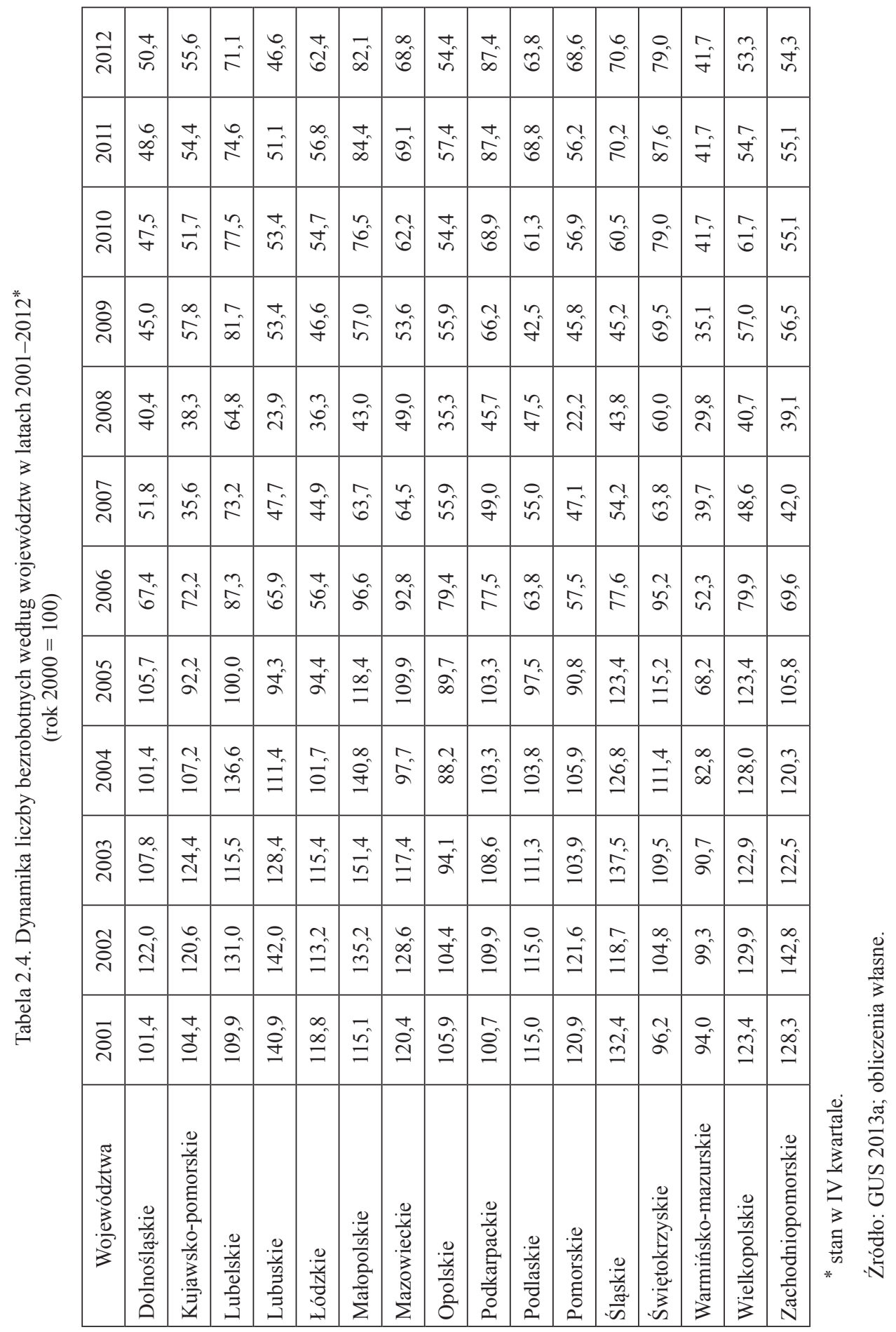



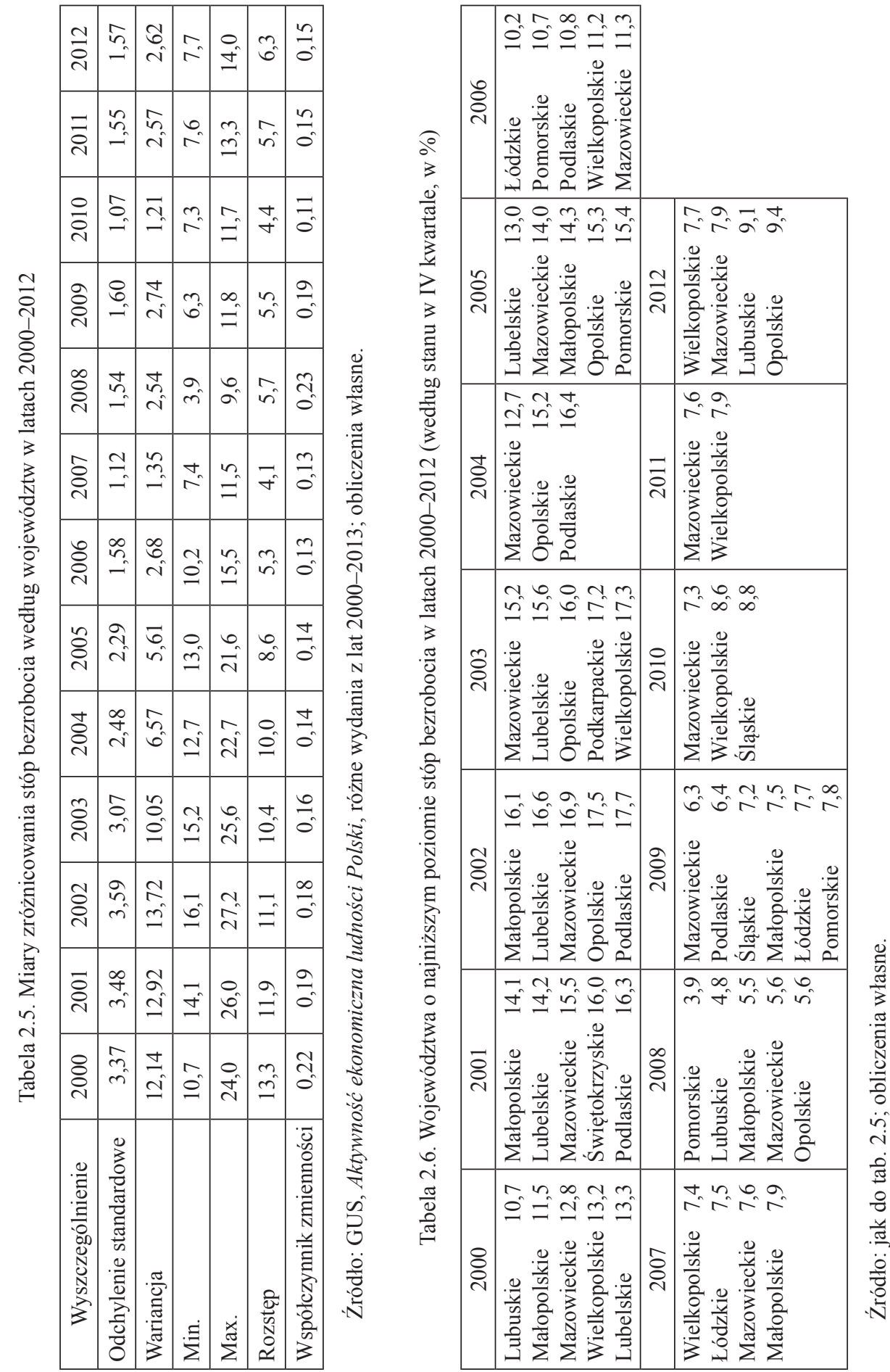
Dane o zróżnicowaniu stóp bezrobocia według województw przedstawiono $\mathrm{w}$ tab. 2.6-2.7. Tab. 2.6 zawiera dane o województwach z najniższym poziomem stóp bezrobocia. Natomiast w tab. 2.7 przedstawione zostały województwa z najwyższym poziomem stóp bezrobocia. Do grupy województw o najniższym poziomie stóp bezrobocia zaliczone zostały te, w których stopa bezrobocia była niższa od średniej arytmetycznej (stóp bezrobocia województw w danym roku) minus 0,6 odchylenia standardowego. $\mathrm{Z}$ kolei do grupy województw o najwyższym poziomie stóp bezrobocia zostały zaliczone te, w których stopa bezrobocia była wyższa od średniej arytmetycznej powiększonej o 0,6 odchylenia standardowego.

$\mathrm{Z}$ analizy danych zawartych $\mathrm{w}$ tab. 2.6-2.7 wynikają następujące wnioski. Po pierwsze, we wszystkich latach analizowanego okresu w grupie województw z najniższymi stopami bezrobocia znajdowało się tylko województwo mazowieckie. Bardzo dobra sytuacja na rynku pracy w tym województwie nie jest zaskakująca z uwagi na to, że jego stolicą jest stolica Polski. Cechuje się ono najwyższym poziomem rozwoju społeczno-gospodarczego. W większości lat $\mathrm{w}$ badanym okresie w grupie województw o najniższym poziomie stóp bezrobocia znalazło się również województwo wielkopolskie, które charakteryzuje się wysokim poziomem rozwoju gospodarczego oraz wysokim poziomem urbanizacji. Po drugie, w grupie województw o najniższym poziomie stóp bezrobocia siedmiokrotnie znalazło się województwo małopolskie oraz pięciokrotnie województwa: podlaskie i lubelskie.

Niski poziom stóp bezrobocia $\mathrm{w}$ tych województwach może być w pewnej mierze rezultatem tego, że są to województwa typowo rolnicze z dominacją drobnych gospodarstw rolnych, które w okresach złej koniunktury zasysają nadwyżki siły roboczej. Po trzecie, w grupie województw o najwyższym poziomie stóp bezrobocia można wyodrębnić województwa: warmińsko-mazurskie i zachodniopomorskie. Znajdowały się one w „najgorszej” grupie w każdym z lat analizowanego okresu. Są to województwa „popegeerowskie”, charakteryzujące się relatywnie niskim poziomem rozwoju gospodarczego. Województwo dolnośląskie także znajdowało się w większości lat badanego okresu w grupie województw o najwyższym poziomie stóp bezrobocia. W tym województwie na początku okresu transformacji systemowej zlikwidowano PGR-y, co doprowadziło do pojawienia się wysokiego bezrobocia o charakterze strukturalnym (zob. Kwiatkowski, Tokarski 2007, s. 440).

$\mathrm{Z}$ rozważań przeprowadzonych $\mathrm{w}$ tym podrozdziale wynika, że w badanym okresie występowało zróżnicowanie stóp bezrobocia w ujęciu regionalnym. Zróżnicowanie to miało charakter trwały. Różnice w poziomie stóp bezrobocia w poszczególnych województwach wskazują na występowanie niedopasowań strukturalnych na regionalnych rynkach pracy. 


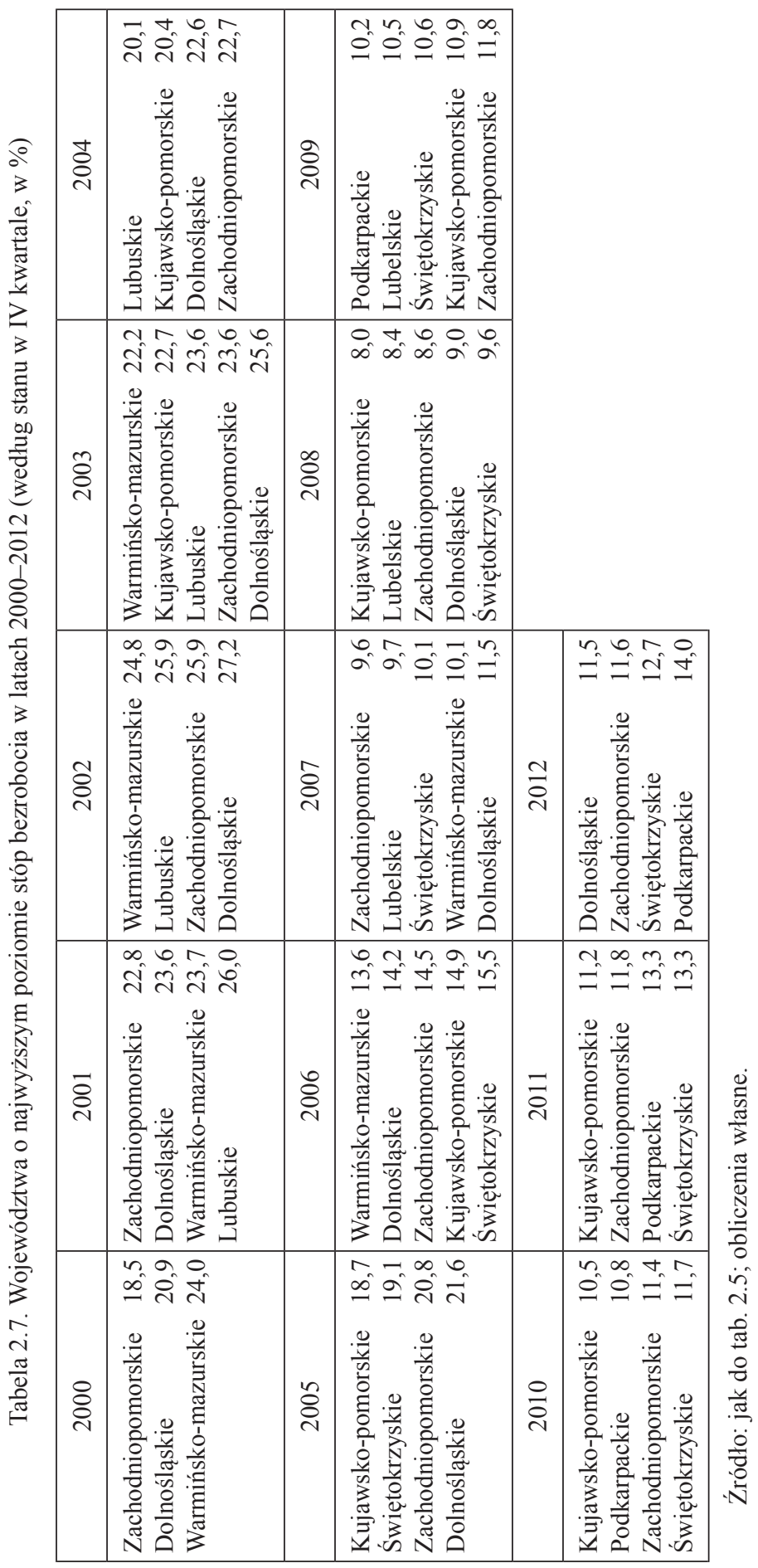




\subsection{Mobilność siły roboczej}

$\mathrm{Z}$ analiz przeprowadzonych w podrozdziałach $2.4-2.5$ wynika, że w latach 1995-2012 występowały w Polsce różnice w natężeniu bezrobocia w przekroju grup społeczno-demograficznych oraz w ujęciu przestrzennym. Różnice te mogłyby być mniejsze, gdyby siła robocza była bardziej mobilna.

Mobilność siły roboczej to zdolność i gotowość osób aktywnych zawodowo do zmiany zawodu, kwalifikacji, gałęzi (branży) gospodarki oraz miejsca zamieszkania. Można zatem mówić o różnych aspektach mobilności siły roboczej. Te różne aspekty podsumowuje R. Schettkat podkreślając, że osoby znajdujące się na rynku pracy mogą przemieszczać się w następujących kierunkach (zob. Schettkat 1996, s. 14):

- $\mathrm{z}$ jednego zawodu do drugiego,

- od jednego pracodawcy do innego,

- z jednej gałęzi gospodarki do innej,

- z jednego regionu (miejsca zamieszkania) do innego,

- między zatrudnieniem, bezrobociem i biernością zawodową.

Poziom mobilności siły roboczej ma istotne znaczenie dla bezrobocia równowagi. Im wyższa mobilność siły roboczej, tym szybszy proces dostosowawczy podaży pracy do popytu na pracę (zob. Gumuła, Socha, Wojciechowski 2007, s. 3). Przyspieszenie procesów dostosowawczych na rynku pracy prowadzi do ograniczenia bezrobocia strukturalnego i tym samym do zmniejszenia poziomu bezrobocia równowagi.

Analizy empiryczne w tym podrozdziale, $\mathrm{z}$ uwagi na dostępność danych statystycznych, obejmują mobilność przestrzenną siły roboczej (migracje wewnętrzne i zagraniczne) oraz napływy i odpływy do bezrobocia.

Analiza danych zawartych w tab. 2.8 pozwala na wyciągnięcie następujących wniosków. W latach 1995-2012 wielkość migracji wewnętrznych (mierzonych napływami migracyjnymi na 1000 mieszkańców) utrzymywała się na stosunkowo niskim poziomie.

Nawet wejście Polski do UE i związane z nim przyspieszenie wzrostu gospodarczego w Polsce w niewielkim stopniu wpłynęło na poziom napływów migracyjnych. Niski poziom mobilności wewnętrznej można tłumaczyć względami społeczno-ekonomicznymi. Do zmiany miejsca zamieszkania w celu poszukiwania pracy mogły np. zniechęcać zbyt niskie różnice w poziomie wynagrodzeń oraz relatywnie wysokie koszty zakupu lub wynajmu mieszkań. 
Tabela 2.8. Napływy migracyjne (wewnętrzne) na 1000 mieszkańców ogółem oraz według płci w Polsce w latach 1995-2012 (w osobach)

\begin{tabular}{|l|c|c|c|c|c|c|c|c|c|}
\cline { 2 - 11 } \multicolumn{1}{c|}{} & \multicolumn{10}{c|}{ Lata } \\
\cline { 2 - 11 } \multicolumn{1}{c|}{} & 1995 & 1996 & 1997 & 1998 & 1999 & 2000 & 2001 & 2002 & 2003 \\
\hline Ogółem & 10,9 & 11,1 & 10,8 & 11,0 & 11,3 & 10,3 & 9,7 & 10,6 & 11,3 \\
\hline Mężczyźni & 5,3 & 5,4 & 5,2 & 5,3 & 5,3 & 4,9 & 4,6 & 5,0 & 5,3 \\
\hline Kobiety & 5,6 & 5,7 & 5,6 & 5,7 & 6,0 & 5,4 & 5,1 & 5,6 & 6,0 \\
\hline & \multicolumn{10}{|c|}{ Lata } \\
\cline { 2 - 11 } & 2004 & 2005 & 2006 & 2007 & 2008 & 2009 & 2010 & 2011 & 2012 \\
\hline Ogółem & 11,3 & 11,1 & 12,4 & 13,4 & 10,6 & 10,6 & 11,4 & 11,3 & 10,6 \\
\hline Mężczyźni & 5,3 & 5,2 & 5,8 & 6,3 & 4,9 & 4,8 & 5,3 & 5,2 & 4,9 \\
\hline Kobiety & 6,0 & 5,9 & 6,6 & 7,1 & 5,8 & 5,8 & 6,1 & 6,1 & 5,7 \\
\hline
\end{tabular}

Źródło: GUS, Bank Danych Lokalnych, www.stat.gov.pl; obliczenia własne.

Warto podkreślić, że kobiety charakteryzowały się wyższym poziomem mobilności wewnątrz kraju, co można objaśniać nie tylko względami ekonomicznymi, ale też rodzinnymi i chęcią zdobycia wykształcenia.

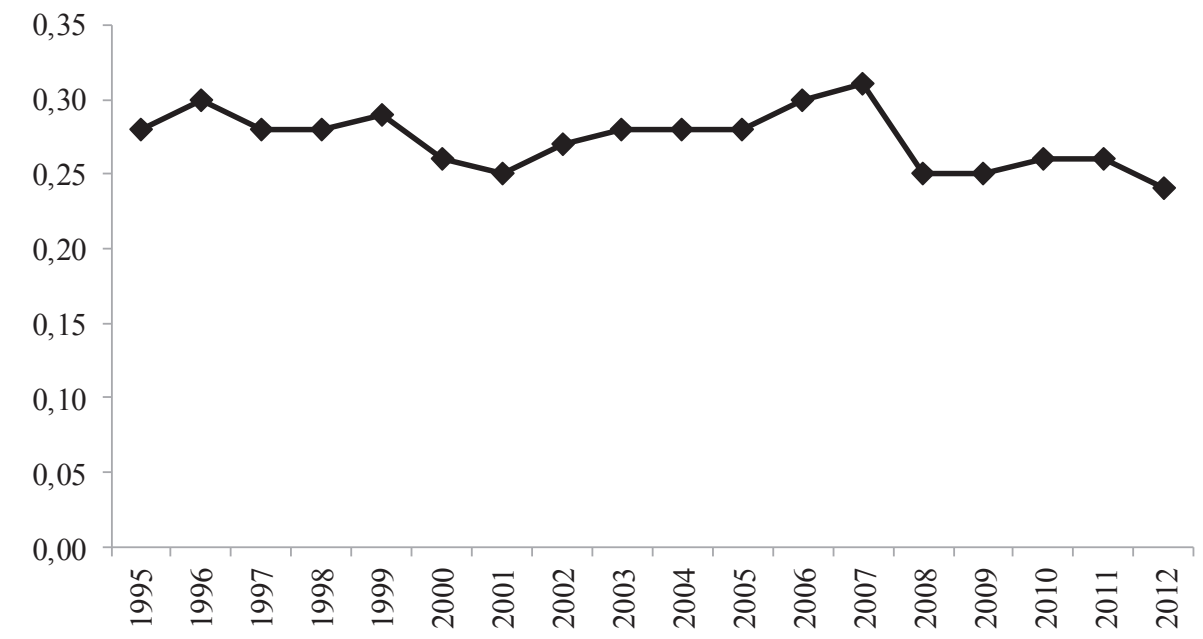

Wykres 2.4. Stopy przepływów międzywojewódzkich* w Polsce w latach 1995-2012 (w \%)

* stopa przepływów międzywojewódzkich to relacja sumy napływów (bądź odpływów) migracyjnych do wszystkich województw do liczby ludności Polski.

Źródło: jak do tab. 2.8; obliczenia własne. 
Przyjrzyjmy się tendencjom zmian migracji międzywojewódzkich, które są częścią migracji wewnętrznych, w latach 1995-2012 (zob. wykres 2.4). Z wykresu 2.4 wynikają następujące wnioski. W analizowanym okresie wielkość migracji wojewódzkich utrzymywała się na stabilnym poziomie. Stopy przepływów międzywojewódzkich oscylowały w analizowanym okresie na poziomie $0,25-0,31 \%$. Po wejściu Polski do UE przepływy międzywojewódzkie zwiększyły się w latach 2005-2007 o 0,03\%. Ponadto, stopy przepływów międzywojewódzkich charakteryzowały się tendencją spadkową w latach 1996-2001. Z kolei w latach 2002-2007 wystąpiła bardzo słaba tendencja wzrostowa stóp przepływów międzywojewódzkich. Tendencja wzrostowa w zakresie migracji międzywojewódzkich została zahamowana w 2008 r. W następnych latach wystąpiła stabilizacja stóp przepływów międzywojewódzkich na nieco niższym poziomie niż w latach 2002-2007. Niższy poziom stóp przepływów międzywojewódzkich po 2008 r. można tłumaczyć osłabieniem koniunktury gospodarczej w Polsce spowodowanym światowym kryzysem finansowym.

Uogólniając, w całym analizowanym okresie migracje wewnętrzne utrzymywały się na stosunkowo niskim poziomie. Niski poziom mobilności wewnętrznej jest barierą dla obniżania poziomu niedopasowań strukturalnych, tym bardziej, że prezentowane dane obejmują nie tylko przemieszczenia w poszukiwaniu pracy, ale także zmiany miejsca zamieszkania spowodowane względami osobistymi.

Po wstąpieniu Polski do UE nastąpił znaczny wzrost migracji zagranicznych z Polski, zwłaszcza do krajów UE, które otworzyły swoje rynki pracy. Tab. 2.9 zawiera dane o saldach migracji zagranicznych na 1000 mieszkańców w latach 1995-2012 w Polsce w przekroju płci. Z analizy tych danych wynikają następujące wnioski. W całym tym okresie saldo migracji zagranicznych na pobyt stały utrzymywało się na ujemnym poziomie. Oznacza to, że w tym okresie liczba ludności Polski z tytułu migracji zagranicznych na pobyt stały malała. Po przystąpieniu Polski do UE, w latach 2004-2006 r. rosło (co do wartości bezwzględnej) saldo migracji zagranicznych na pobyt stały w Polsce, to znaczy, że więcej ludzi z Polski wyjeżdżało niż przyjeżdżało. Największy ubytek ludności z tytułu migracji zagranicznych na pobyt stały wystąpił w 2006 r. Od 2007 r. następował sukcesywny spadek (co do wartości bezwzględnej) salda migracji zagranicznych na pobyt stały. Poprawa salda migracji zagranicznych na pobyt stały w 2009 r. mogła być spowodowana światowym kryzysem finansowym. Należy jednak zwrócić uwagę, że w następnych latach saldo migracji zagranicznych ulegało sukcesywnemu pogorszeniu. 
Tabela 2.9. Saldo migracji zagranicznych na pobyt stały na 1000 mieszkańców ogółem oraz według płci w Polsce w latach 1995-2012

\begin{tabular}{|l|c|c|c|c|c|c|c|c|c|}
\cline { 2 - 10 } \multicolumn{1}{c|}{} & \multicolumn{9}{c|}{ Lata } \\
\cline { 2 - 11 } \multicolumn{1}{c|}{} & 1995 & 1996 & 1997 & 1998 & 1999 & 2000 & 2001 & 2002 & 2003 \\
\hline Ogółem & $-0,47$ & $-0,34$ & $-0,31$ & $-0,34$ & $-0,37$ & $-0,51$ & $-0,44$ & $-0,47$ & $-0,36$ \\
\hline Mężczyźni & $-0,23$ & $-0,17$ & $-0,15$ & $-0,19$ & $-0,19$ & $-0,26$ & $-0,23$ & $-0,23$ & $-0,18$ \\
\hline Kobiety & $-0,24$ & $-0,17$ & $-0,15$ & $-0,16$ & $-0,18$ & $-0,26$ & $-0,21$ & $-0,24$ & $-0,18$ \\
\hline & \multicolumn{10}{|c|}{ Lata } \\
\cline { 2 - 11 } & 2004 & 2005 & 2006 & 2007 & 2008 & 2009 & 2010 & 2011 & 2012 \\
\hline Ogółem & $-0,25$ & $-0,34$ & $-0,95$ & $-0,54$ & $-0,39$ & $-0,03$ & $-0,05$ & $-0,11$ & $-0,17$ \\
\hline Mężczyźni & $-0,13$ & $-0,18$ & $-0,56$ & $-0,32$ & $-0,19$ & 0,07 & 0,03 & $-0,01$ & $-0,12$ \\
\hline Kobiety & $-0,12$ & $-0,15$ & $-0,39$ & $-0,21$ & $-0,20$ & $-0,10$ & $-0,08$ & $-0,10$ & $-0,05$ \\
\hline
\end{tabular}

Źródło: jak do tab. 2.8; obliczenia własne.

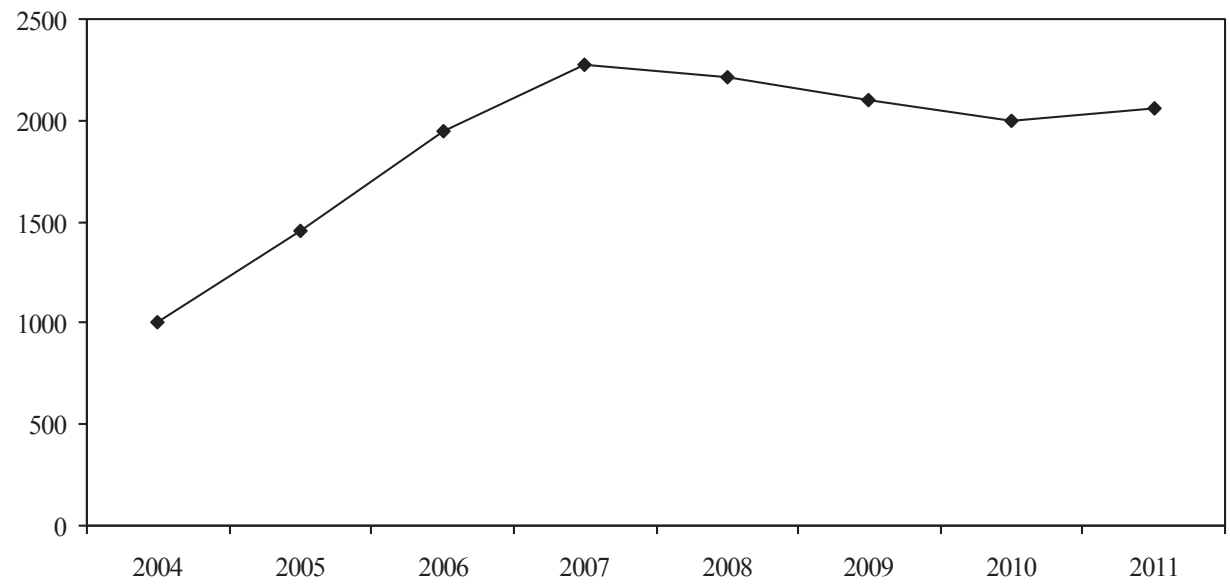

Wykres 2.5. Liczba emigrantów z Polski na pobyt czasowy w latach 2004-2011 (w tys. osób)

Źródło: GUS 2012b, s. 3.

Dane o emigracji na pobyt stały nie pokazują całej skali zjawiska migracji zagranicznych w Polsce. Po wejściu Polski do UE w 2004 r. i otwarciu rynków pracy niektórych krajów UE nastąpił wzrost emigracji zarobkowej Polaków. Dane o liczbie emigrantów z Polski na pobyt czasowy w latach 2004-2011 przedstawiono na wykresie 2.5. Wynika z niego, że w latach 2004-2007 występowała silna tendencja wzrostowa emigracji zarobkowej Polaków. W 2007 r. za granicę w celach zarobkowych wyjechało 2 mln 270 tys. Polaków. Tak duża skala emigracji zarobkowej może w pewnym stopniu tłumaczyć wyraźną poprawę sytuacji na rynku pracy w Polsce w latach 2006-2008. W 2008 r., pomimo spowolnienia koniunktury w krajach UE, do pracy za granicą wyjechało z Polski ponad $2 \mathrm{mln}$ osób. Tendencja spadkowa w wyjazdach na pobyt czasowy została zatrzymana 
w 2010 r. Podsumowując, można powiedzieć, że wejście Polski do UE spowodowało istotny wzrost mobilności przestrzennej dzięki wzrostowi emigracji na pobyt czasowy.

Tabela 2.10. Miary płynności zasobu bezrobocia w Polsce w latach 1995-2012

\begin{tabular}{|c|c|c|c|c|}
\hline Rok & $\begin{array}{c}\text { Stopy napływów } \\
(\mathrm{w} \%)\end{array}$ & $\begin{array}{c}\text { Stopy odpływów } \\
(\mathrm{w} \%)\end{array}$ & $\begin{array}{c}\text { Wskaźnik płynności } \\
\text { zasobu bezrobocia }\end{array}$ & $\begin{array}{c}\text { Okres trwania bez- } \\
\text { robocia } \\
\text { (w miesiącach) }\end{array}$ \\
\hline 1995 & 83,6 & 90,9 & 0,87 & 12,2 \\
\hline 1996 & 84,6 & 94,9 & 0,90 & 11,4 \\
\hline 1997 & 86,9 & 109,5 & 0,98 & 8,5 \\
\hline 1998 & 116,5 & 116,2 & 1,16 & 10,4 \\
\hline 1999 & 139,9 & 111,6 & 1,26 & 13,8 \\
\hline 2000 & 105,4 & 90,3 & 0,98 & 15,3 \\
\hline 2001 & 91,6 & 76,4 & 0,84 & 18,1 \\
\hline 2002 & 81,9 & 78,6 & 0,80 & 14,2 \\
\hline 2003 & 82,1 & 83,4 & 0,83 & 12,6 \\
\hline 2004 & 84,5 & 90,1 & 0,87 & 11,0 \\
\hline 2005 & 93,1 & 100,7 & 0,97 & 8,8 \\
\hline 2006 & 97,1 & 113,8 & 1,05 & 6,9 \\
\hline 2007 & 107,9 & 132,2 & 1,20 & 6,4 \\
\hline 2008 & 141,8 & 157,4 & 1,50 & 8,5 \\
\hline 2009 & 209,2 & 180,8 & 1,95 & 8,6 \\
\hline 2010 & 146,2 & 143,6 & 1,45 & 10,3 \\
\hline 2011 & 132,6 & 131,2 & 1,32 & \\
\hline 2012 & 133,9 & 126,1 & 1,30 & \\
\hline
\end{tabular}

* okres trwania bezrobocia zdefiniowano jako relację liczby bezrobotnych na koniec roku do wielkości odpływu w ciągu roku (są to niezakończone okresy trwania bezrobocia). własne.

Źródło: GUS, Bezrobocie rejestrowane w Polsce, różne wydania z lat 1995-2013; obliczenia

Przejdźmy obecnie do analizy płynności zasobu bezrobocia w Polsce w latach 1995-2012 (zob. tab. 2.10). Stopa napływów do bezrobocia definiowana jest tu jako stosunek napływu do bezrobocia $\mathrm{w}$ danym roku do liczby bezrobotnych na koniec poprzedniego roku. Stopę odpływu z bezrobocia zdefiniowano jako relację wielkości odpływu z bezrobocia w ciągu roku do liczby bezrobotnych na koniec poprzedniego roku. Takie ujęcie stóp napływu i odpływu pozwala 
na dokonywanie porównań obu tych wielkości. Wskaźnik płynności zasobu bezrobocia opisuje zaś równanie (2.1) (zob. Kucharski 2002, s. 100):

gdzie:

$$
b_{p}=\frac{N_{b, t}+O_{b, t}}{2 U_{t-1}}
$$

$N_{b, t}$ - napływy do bezrobocia w ciągu danego okresu (np. roku),

$O_{b, t}$ - odpływy z bezrobocia w ciągu danego okresu (np. roku),

$U_{t-1}-$ liczba bezrobotnych (zasób bezrobocia) na koniec poprzedniego okresu (np. roku).

Im wyższa przy tym wartość wskaźnika płynności, tym bardziej dynamiczny jest zasób bezrobocia. Natomiast im bardziej dynamiczny jest zasób bezrobocia, tym niższy jest przeciętny czas trwania bezrobocia.

$\mathrm{Z}$ analizy danych zawartych w tab. 2.10 wynika, że w latach 1995-2012 występowała zmienna tendencja stóp napływów i odpływów z bezrobocia. W latach 1995-1997 oraz 2003-2008 stopy napływów do bezrobocia były niższe od stóp odpływu z bezrobocia. W pozostałych latach stopy napływów do bezrobocia przewyższały natomiast stopy odpływów z bezrobocia. Najwyższy poziom stóp napływów i odpływów z bezrobocia wystąpił w 2009 r. (stopa napływu w tym roku wyniosła 209,2\%, zaś stopa odpływu 180,8\%). To właśnie w 2009 r. różnica między stopą napływu do bezrobocia i stopą odpływu z bezrobocia była najwyższa w całym badanym okresie. Należy też podkreślić, że w latach 2004-2008 nastąpił znaczący wzrost stóp odpływów z bezrobocia przy znacznie słabszym wzroście stóp napływu do bezrobocia.

Wskaźnik płynności zasobu bezrobocia w analizowanym okresie charakteryzował się tak samo zmienną tendencją. Najwyższy poziom płynności tego zasobu wystąpił w 2009 r.

Do 2005 r. (za wyjątkiem 1997 r.) długość niezakończonego przeciętnego okresu trwania bezrobocia była wyższa niż 10 miesięcy. W 2001 r. niezakończony przeciętny okres trwania bezrobocia wynosił aż 18,1 miesięcy. Natomiast w 2008 r. przeciętny niezakończony okres trwania bezrobocia wynosił 6,4 miesiąca. Osłabienie koniunktury gospodarczej po 2009 r. spowodowane światowym kryzysem finansowym przyczyniło się do wydłużenia przeciętnego okresu trwania bezrobocia w latach 2009-2012.

\subsection{Niedopasowania strukturalne}

Utrzymywanie się zróżnicowania stóp bezrobocia w przekroju takich cech, jak: wykształcenie, zawód czy też miejsce zamieszkania (miasto/wieś oraz region) może wskazywać na występowanie niedopasowań strukturalnych oraz ograniczonej mobilności siły roboczej. 
Poziom niedopasowań strukturalnych ma istotne znaczenie zarówno dla kształtowania się poziomu bezrobocia faktycznego, jak i bezrobocia równowagi. Wzrost niedopasowań strukturalnych prowadzi bowiem do powstawania bezrobocia strukturalnego, które jest częścią bezrobocia faktycznego oraz bezrobocia równowagi.

Do pomiaru poziomu niedopasowań strukturalnych wykorzystuje się najczęściej tzw. indeksy niedopasowań strukturalnych (mismatch indices). Ogólna interpretacja dla wszystkich indeksów niedopasowań strukturalnych jest następująca - wartość poszczególnych indeksów pozwala określić, jaki odsetek siły roboczej powinien przepłynąć do innych grup (na inne subrynki pracy), aby zniknęły niedopasowania strukturalne.

W analizach niedopasowań strukturalnych wykorzystywane są cztery indeksy niedopasowań: $M 1, M 2, M 3$ i $M 4$. Indeks $M 1$ wykorzystywany w analizach niedopasowań strukturalnych został wyprowadzony przez R. Jackmana i R. Ropera (zob. Jackman, Roper 1987, s. 11-12). Indeks ten można obliczyć w oparciu o następującą formułę:

$$
M 1=\frac{1}{2} \sum_{i}\left|b_{i}-v_{i}\right| \quad M 1 \in\langle 0,1\rangle
$$

gdzie:

$b_{i}=\frac{U_{i}}{\sum_{i} U_{i}}-$ udział bezrobotnych $\mathrm{z}$ danej grupy w łącznej liczbie bezrobotnych, $v_{i}=\frac{V_{i}}{\sum_{i} V_{i}} \quad-$ udział wolnych ofert pracy adresowanych do danej grupy w łacz-

Im wyższa jest wartość indeksu $M 1$, tym wyższy jest poziom niedopasowań strukturalnych. Wartość indeksu $M 1$ równa 0 oznacza, że w danej grupie ludności nie występują niedopasowania strukturalne.

Wskaźnik niedopasowań strukturalnych $M 2$ stanowi rozwinięcie indeksu $M 1$ (zob. Jackman, Roper 1987, s. 13) i można go opisać wzorem:

$$
M 2=1-\sum_{i}\left(b_{i} v_{i}\right)^{\frac{1}{2}} \quad M 2 \in\langle 0,1\rangle
$$

Wielkości wykorzystywane do oszacowania indeksu $M 2$ są zdefiniowane tak samo, jak w równaniu (2.2). Oba indeksy wskazują, jaka część zasobu bezrobotnych musi się dostosować do istniejących ofert pracy, aby zniknęły niedopasowania strukturalne.

Indeks $M 2$ jest bardziej precyzyjną miarą niedopasowań strukturalnych niż indeks $M 1$ ze względu na to, że jego konstrukcja opiera się na funkcji dopasowań typu Cobb-Douglasa. Jednakże do wyznaczenia obu indeksów niezbędne są wiarygodne dane o wolnych miejscach pracy. Niestety, dostępne dane o wolnych miejscach pracy nie są kompletne. 
Bardziej wiarygodnym miernikiem niedopasowań strukturalnych jest indeks M3. Wskaźnik ten został wyprowadzony przez Jackmana, Layarda i Savourie'go. Konstrukcja tego wskaźnika jest oparta na koncepcji NAIRU. Layard, Nickell i Jackman wykazują, że stopa bezrobocia NAIRU jest zależna od poziomu niedopasowań strukturalnych mierzonych przy pomocy indeksu $M 3$ (zob. Layard, Nickell, Jackman 2005, s. 46-47). Indeks M3 oblicza się w oparciu o następującą formułę:

$$
M 3=\frac{1}{2} \operatorname{var}\left(\frac{u_{i}}{u}\right)
$$

gdzie:

var - wariancja,

$u_{i} \quad$ - stopa bezrobocia $\mathrm{w}$ danej grupie ludności,

$u$ - stopa bezrobocia w całej gospodarce.

Im wyższa wartość indeksu $M 3$, tym wyższy jest poziom niedopasowań strukturalnych na danym subrynku pracy ${ }^{9}$. Spadek wartości indeksu $M 3$ oznacza zmniejszenie niedopasowań strukturalnych $\mathrm{w}$ danej grupie siły roboczej (na danym subrynku pracy).

Ostatnim z indeksów niedopasowań strukturalnych wykorzystywanych w analizach jest indeks $M 4$. Wskazuje on na poziom niedopasowań strukturalnych wynikających z popytowej strony rynku pracy. Jest określany również jako miara niedopasowań sektorowych (index of industrial mismatch). Można go opisać wzorem:

$$
M 4=\left(\sum_{i} \frac{L_{i t}}{L_{t}}\left(\Delta \log L_{i t}-\Delta \log L_{t}\right)^{2}\right)^{\frac{1}{2}}
$$

gdzie:

$L_{i t}$ - liczba pracujących w danej grupie ludności (w przekroju zawodów, wykształcenia, sekcji PKD) w danym okresie,

$L_{t}$ - łączna liczba pracujących w danym okresie w gospodarce.

Im wyższa jest wartość oszacowanego indeksu $M 4$, tym wyższy jest poziom niedopasowań strukturalnych oraz mniejsze zmiany w strukturze pracujących. Zastosowanie tego indeksu do mierzenia zmian struktury pracujących spotkało się z krytyką niektórych ekonomistów ze względu na to, że zmiany struktury pracujących zależą też od zmian poziomu koniunktury gospodarczej (zob. Abraham, Katz 1986, s. 521).

${ }^{9}$ Jeśli $M 3$ wynosi np. 0,2 w grupie zawodów, to aby zniknęły niedopasowania strukturalne, $20 \%$ bezrobotnych powinno się przekwalifikować. 
Tabela 2.11. Oszacowania indeksu M3 w wybranych przekrojach dla lat 1995-2012 (w \%)

\begin{tabular}{|c|c|c|c|c|c|c|c|c|c|}
\hline & \multicolumn{9}{|c|}{ Lata } \\
\hline & 1995 & 1996 & 1997 & 1998 & 1999 & 2000 & 2001 & 2002 & 2003 \\
\hline Miasto/wieś & 0,78 & 0,56 & 0,33 & 0,47 & 0,19 & 0,56 & 0,66 & 1,06 & 0,58 \\
\hline $\begin{array}{l}\text { Zawody } \\
\text { (wielkie grupy) }\end{array}$ & 18,6 & 22,2 & 25,7 & 24,6 & 25,1 & 20,9 & 21,1 & 18,9 & 18,8 \\
\hline \multirow[t]{3}{*}{ Sekcje PKD } & 14,8 & 17,6 & 14,9 & 13,1 & 16,0 & 12,6 & 14,3 & 16,3 & 18,1 \\
\hline & \multicolumn{9}{|c|}{ Lata } \\
\hline & 2004 & 2005 & 2006 & 2007 & 2008 & 2009 & 2010 & 2011 & 2012 \\
\hline Miasto/wieś & 0,34 & 0,60 & 0,26 & 0,11 & 0,02 & 0,03 & 0,14 & 0,01 & 0,02 \\
\hline $\begin{array}{l}\text { Zawody } \\
\text { (wielkie grupy) }\end{array}$ & 20,5 & 21,8 & 21,2 & 24,0 & 24,0 & 25,6 & 20,7 & 27,4 & 27,7 \\
\hline Sekcje PKD & 15,0 & 15,3 & 14,0 & 13,8 & 16,5 & 9,2 & 15,6 & 12,0 & 13,3 \\
\hline
\end{tabular}

Źródło: GUS, Aktywność Ekonomiczna Ludności Polski, różne wydania z lat 2000-2013; obliczenia własne.

W tab. 2.11 przedstawiono wyniki oszacowań indeksu $M 3$ w przekroju miasto/wieś, zawodów oraz sekcji PKD w latach 1995-2012. Z analizy tych danych wynikają następujące wnioski:

1. Najniższy poziom niedopasowań strukturalnych występował $\mathrm{w}$ badanym okresie w przekroju miasto/wieś. Przyczyn tego stanu można upatrywać w utrzymującej się w dalszym ciągu strukturze gospodarstw rolnych. Zmiany struktury gospodarstw rolnych dokonują się powoli. System dopłat unijnych opóźnia te dostosowania. W badanym okresie zwracają uwagę niewielkie zmiany indeksu $M 3 \mathrm{w}$ przekroju miasto/wieś. Warto również podkreślić, że poziom niedopasowań strukturalnych $\mathrm{w}$ tym zakresie zmniejszał się po wejściu Polski do UE, osiągając w latach 2008-2009 oraz 2011-2012 wartości bliskie 0, a co mogłoby wskazywać na wyeliminowanie niedopasowań strukturalnych w tym przekroju.

2. Najwyższy poziom niedopasowań strukturalnych występował w analizowanym okresie w przekroju zawodowym (indeks $M 3 \mathrm{w}$ całym badanym okresie utrzymywał się na poziomie $18,6-27,7 \%)^{10}$. Wysoki poziom niedopasowań strukturalnych w przekroju zawodów wynika z utrzymującej się w dal-

${ }^{10}$ Stopy bezrobocia w przekroju zawodów nie są publikowane przez GUS. Zostały oszacowane w oparciu o dane o liczbie bezrobotnych i pracujących według zawodów. Należy jednak zwrócić uwagę, że dane o liczbie bezrobotnych według zawodów dotyczą tylko osób, które miały przeszłość zawodową. 
szym ciągu niskiej mobilności zawodowej w Polsce. Tendencja spadkowa indeksu $M 3$ w tej grupie została zahamowana w 2004 r. Od 2005 r. indeks ten sukcesywnie wzrastał (za wyjątkiem 2010 r.). Wysoki poziom niedopasowań strukturalnych w przekroju zawodów i sekcji PKD może być rezultatem niedostosowania systemu edukacji do potrzeb rynku pracy. Do wzrostu niedopasowań strukturalnych w tym przekroju mógł się również przyczynić wzrost emigracji zarobkowej.

3. Niższy poziom niedopasowań strukturalnych w porównaniu do grup zawodów występował w analizowanym okresie w przekroju sekcji PKD. Również w przekroju sekcji PKD indeks $M 3$ charakteryzował się zmienną tendencją. W badanym okresie wystąpiła nieznaczna tendencja spadkowa niedopasowań strukturalnych w tym przekroju.

W celu oszacowania wartości indeksów $M 1$ i $M 2$ niezbędne są dane o wolnych miejscach pracy ogółem w różnych przekrojach. Z uwagi na to, że większość przedsiębiorstw nie zgłasza do urzędów pracy informacji o wolnych miejscach pracy, dane o wolnych miejscach pracy, jakimi dysponują urzędy pracy, są niedoszacowane. Ponadto, nie są dostępne ciągłe dane o wolnych miejscach pracy w przekroju zawodów, województw oraz sekcji PKD.

W tab. 2.12 przedstawiono wyniki oszacowań indeksów $M 1$ i $M 2$ według województw. Nie są osiągalne publikowane dane statystyczne o liczbie wolnych miejsc pracy w przekroju województw w latach 2005-2010. Z tab. 2.12 wynikają następujące wnioski. Po pierwsze, wartość obu indeksów różni się od siebie znacząco. Różnice w poziomie obu indeksów wynikają z zastosowania różnych formuł do ich obliczania. Wzrost wartości indeksu $M 1$ lub $M 2$ oznacza wzrost niedopasowań strukturalnych, natomiast ich spadek oznacza zmniejszenie poziomu niedopasowań strukturalnych w danym przekroju. Po drugie, wartość obu indeksów zmieniała się (za wyjątkiem 2000 r. w przypadku indeksu M1) w tym samym kierunku w analizowanym okresie. W latach 1999-2003 wystąpiła tendencja wzrostowa obu indeksów, natomiast w 2004 r. nastąpił spadek wartości obu indeksów. Po trzecie, w latach 2011-2012 oba indeksy charakteryzowały się tendencją spadkową. Należy również podkreślić, że w 2011 r. indeks $M 1$ osiągnął najwyższą wartość w badanym okresie.

Tabela 2.12. Oszacowania indeksów $M 1$ i $M 2$ według województw w latach 1999-2004 oraz w latach 2011-2012 (w \%)

\begin{tabular}{|l|r|r|r|r|r|r|r|r|}
\cline { 2 - 9 } \multicolumn{1}{c|}{} & 1999 & 2000 & 2001 & 2002 & 2003 & 2004 & 2011 & 2012 \\
\hline Indeks $M 1$ & 17,5 & 19,2 & 19,1 & 21,9 & 24,9 & 23,2 & 24,8 & 18,4 \\
\hline Indeks $M 2$ & 2,7 & 3,3 & 3,6 & 3,5 & 4,9 & 4,0 & 4,3 & 2,4 \\
\hline
\end{tabular}

Źródło: GUS 2001; GUS 2003; GUS 2013b; www.praca.gov.pl; obliczenia własne. 
Tabela 2.13. Oszacowania indeksu M4 według sekcji PKD w Polsce w latach 2001-2007 (w \%)

\begin{tabular}{|l|c|c|c|c|c|c|c|}
\cline { 2 - 7 } \multicolumn{1}{c|}{} & 2001 & 2002 & 2003 & 2004 & 2005 & 2006 & 2007 \\
\hline Indeks $M 4$ & 9,7 & 6,8 & 5,2 & 6,1 & 4,9 & 7,2 & 7,9 \\
\hline
\end{tabular}

Źródło: GUS, Aktywność Ekonomiczna Ludności Polski, różne wydania z lat 2001-2008; obliczenia własne.

W tab. 2.13 przedstawiono wyniki oszacowań indeksu $M 4 \mathrm{w}$ Polsce w przekroju sekcji PKD. Z powodu zmian PKD w 2008 r. dane dla lat następnych nie są porównywalne. $\mathrm{Z}$ tab. 2.13 wynika, że indeks $M 4$ charakteryzował się zmienną tendencją. Do 2005 r. (z wyjątkiem 2004 r.) malał poziom niedopasowań strukturalnych w przekroju sekcji PKD. Z kolei w latach 2006-2007 wystąpił wzrost niedopasowań strukturalnych w badanym przekroju.

$\mathrm{Z}$ przeprowadzonych analiz $\mathrm{w}$ tym podrozdziale wynika, że $\mathrm{w}$ badanym okresie występowały niedopasowania strukturalne na rynku pracy w Polsce. Największy poziom niedopasowań strukturalnych (szacowanych w oparciu o różne indeksy) utrzymywał się w przekroju zawodów i specjalności oraz według sekcji PKD.

\subsection{Podsumowanie}

Z przeprowadzonych analiz wynika, że w całym badanym okresie poziom bezrobocia w Polsce cechował się dużą zmiennością. Liczba bezrobotnych i stopy bezrobocia były skorelowane ze zmianami PKB. W okresach przyspieszenia wzrostu gospodarczego stopy bezrobocia i liczba bezrobotnych silniej malała, zaś w okresach spowolnienia występowała tendencja wzrostowa obu omawianych wielkości. Trzeba jednak podkreślić, że pozytywny wpływ ożywienia gospodarczego na sytuację na rynku pracy był znacznie silniejszy w okresie po przystąpieniu Polski do UE. Jednak nawet w okresach bardzo dobrej koniunktury utrzymywał się pewien poziom bezrobocia, co tym samym wskazuje na występowanie bezrobocia niewrażliwego na poprawę koniunktury gospodarczej.

Istotnym problemem polskiego rynku pracy do $2007 \mathrm{r}$. był wysoki odsetek bezrobotnych długookresowo. Udział tej grupy zmalał znacząco w 2008 r., ale było to częściowo spowodowane zmianą metodologii stosowanej przez GUS. W kolejnych latach wystąpiła tendencja wzrostowa udziału bezrobotnych długookresowo w bezrobociu ogółem na skutek spowolnienia gospodarczego spowodowanego światowym kryzysem finansowym.

W badanym okresie wystąpiło ponadto dosyć silne zróżnicowanie stóp bezrobocia według wykształcenia, wieku oraz w przekroju miasto/wieś, co wskazuje na występowanie niedopasowań strukturalnych. Ponieważ klasyfikacja zawodów jest powiązana z poziomem wykształcenia, silne zróżnicowanie stóp bezrobocia 
w przekroju wykształcenia wskazuje pośrednio na duże zróżnicowanie zagrożenia bezrobociem w przekroju zawodów i specjalności.

Pomimo pewnej poprawy, w dalszym ciągu utrzymuje się znaczne zróżnicowanie sytuacji na regionalnych rynkach pracy. Należy podkreślić, że zróżnicowanie to ma charakter trwały. Województwa zachodniopomorskie i warmińsko-mazurskie w całym badanym okresie należały do grupy województw o najwyższych stopach bezrobocia.

Wyniki analiz empirycznych potwierdziły, że największy poziom niedopasowań strukturalnych na rynku pracy w Polsce wystąpił w przekroju zawodów, specjalności i wykształcenia. Znaczny wzrost stóp bezrobocia w grupie z wykształceniem wyższym wskazuje na niedopasowanie popytu na pracę do podaży wśród osób z wykształceniem wyższym.

Przyczyn utrzymujących się niedopasowań strukturalnych można upatrywać w stosunkowo niskim poziomie mobilności wewnętrznej Polaków. Jak wskazują dane empiryczne, poziom migracji zagranicznych po przystąpieniu Polski do UE był bowiem wysoki. Niemniej należy zwrócić uwagę, że zwiększenie mobilności zewnętrznej może prowadzić do pogłębienia niedopasowań strukturalnych w niektórych grupach zawodowych. 


\section{Rozdział 3}

\section{Metody pomiaru bezrobocia równowagi oraz wyniki oszacowań stóp bezrobocia NAIRU dla wybranych krajów Europy Środkowo-Wschodniej}

Celem niniejszego rozdziału jest przedstawienie metod pomiaru bezrobocia równowagi. Zaprezentowano tu także wyniki oszacowań bezrobocia równowagi w wybranych krajach Europy Środkowo-Wschodniej.

\subsection{Metody pomiaru bezrobocia równowagi}

Wielkość bezrobocia równowagi jest trudno mierzalna, stąd tak ważne znaczenie ma dobór właściwych metod jego szacowania. Istnieje zarazem kilka sposobów różniących się podstawami teoretycznymi i wykorzystywanymi formułami matematycznymi mierzenia wielkości bezrobocia równowagi. M. Socha i U. Sztanderska (2000) grupują je w czterech następujących ujęciach jako metody oparte o:

- przepływy siły roboczej,

- krzywą Phillipsa,

- krzywą Beveridge'a,

- szacunki produkcji potencjalnej.

Metody te będą dalej omówione bardziej szczegółowo. Najczęściej stosowanymi metodami szacowania bezrobocia równowagi są metody oparte na koncepcji krzywej Phillipsa oraz przepływach siły roboczej.

Nieco inną klasyfikację metod szacowania bezrobocia równowagi można znaleźć w opracowaniu G. Kuczyńskiego i K. Strzały (2006). Autorzy ci wyróżniają trzy podejścia stosowane przy wyznaczaniu bezrobocia równowagi, które implikują trzy odmienne metody (zob. Kuczyński, Strzała 2006, s. 314):

- polegające na budowie i wykorzystaniu tzw. modeli strukturalnych,

- statystyczne,

- odwołujące się do rozszerzonej krzywej Phillipsa.

Podział ten jest zatem częściowo zbieżny z podziałem metod szacowania bezrobocia równowagi przedstawionym wcześniej. Pierwsze podejście polega 
bowiem na oszacowaniu parametrów strukturalnego modelu ekonometrycznego przedstawiającego kształtowanie się płac i cen w gospodarce. Najszerzej zaś rozpowszechnionym modelem $w$ ramach tego podejścia jest model R. Layarda, S. Nickella oraz R. Jackmana (1991). W oparciu o modele strukturalne stopa bezrobocia równowagi jest wyznaczana przy założeniu, że stopa inflacji pozostaje na niezmienionym poziomie.

Podstawowe zaś zastrzeżenie wysuwane w literaturze przedmiotu względem tego podejścia dotyczy poprawności podstawowych założeń omawianego modelu. Chodzi tu w szczególności o powszechnie przyjmowane założenie o jednostkowej elastyczności substytucji kapitału i pracy (zob. Kuczyński, Strzała 2006, s. 314). Podnoszone są również wątpliwości co do jednoznaczności specyfikacji modelu, identyfikowalności równań oraz wrażliwości uzyskanych oszacowań stopy bezrobocia równowagi względem zmiennych wykorzystywanych w modelu.

Metody statystyczne badania bezrobocia równowagi polegają z kolei na analizie pojedynczego szeregu stopy bezrobocia. Celem tych metod jest dekompozycja stopy bezrobocia na komponent cykliczny oraz trend, który jest utożsamiany ze stopą bezrobocia równowagi. $Z$ uwagi na to, że do szacowania bezrobocia równowagi wykorzystywana jest jedna zmienna, metody statystyczne są popularne. Jednakże ograniczenie się przy wyznaczaniu bezrobocia równowagi do jednej zmiennej jest zbyt dużym uproszczeniem, ponieważ oszacowania stopy bezrobocia równowagi nie są związane $\mathrm{z}$ inflacją, a więc nie mogą być zastosowane w polityce makroekonomicznej. Do metod statystycznych można zaliczyć metody oparte na przepływach siły roboczej oraz niektóre metody wykorzystywane przy szacowaniu produkcji potencjalnej. Metody odwołujące się do rozszerzonej krzywej Phillipsa polegają na estymacji parametrów tej krzywej przy zastosowaniu różnych metod ekonometrycznych.

\subsubsection{Metody oparte na przeplywach sily roboczej}

Na początku warto zauważyć, że w literaturze ekonomicznej można znaleźć szereg metod szacowania bezrobocia równowagi właśnie w oparciu o przepływy siły roboczej. We wszystkich tych metodach naturalna stopa bezrobocia ${ }^{1}$ jest definiowana jako stopa bezrobocia w warunkach stanu stacjonarnego, czyli w sytuacji, gdy napływy do poszczególnych zasobów (bezrobotnych, pracujących i biernych zawodowo) są równe odpływom z tych zasobów. Przy wyprowadzaniu poszczególnych formuł wykorzystuje się różne ujęcia stanu stacjonarnego ${ }^{2}$.

\footnotetext{
${ }^{1}$ Pojęcie naturalnej stopy bezrobocia oraz bezrobocia równowagi w analizach empirycznych jest używane zamiennie.

${ }^{2} \mathrm{~W}$ warunkach stanu stacjonarnego napływy do zasobu bezrobocia, pracujących oraz biernych zawodowo są równe odpływom z tych zasobów. Oznacza to, że wielkości tych zasobów nie zmieniają się.
} 
Jedną z formuł pozwalających na oszacowanie bezrobocia równowagi w oparciu o przepływy siły roboczej możemy znaleźć w pracach: G. Alogoskoufisa et al. oraz M. Sochy i U. Sztanderskiej (zob. Alogoskoufis et al. 1995, s. 13; Socha, Sztanderska 2000, s. 152). Przy wyprowadzaniu tej formuły zakłada się, że rynek pracy znajduje się w warunkach stanu stacjonarnego. Oznacza to, że przyrost zasobu bezrobocia możemy opisać wzorem:

$$
\Delta U_{t}=U_{t}-U_{t-1}
$$

gdzie:

$U_{t}-$ poziom bezrobocia w okresie $t$,

$U_{t-1}$ - poziom bezrobocia w okresie $(t-1)$,

$\Delta U_{t}-$ przyrost zasobu bezrobocia.

Przyrost zasobu bezrobocia jest równy różnicy między napływami do bezrobocia a odpływami z bezrobocia, a więc możemy go opisać wzorem:

$$
\Delta U_{t}=(E U+N U)-(U E+U N)
$$

gdzie:

$E U$ - napływy osób z zatrudnienia do bezrobocia,

$N U$ - napływy osób z bierności zawodowej do bezrobocia,

$U E$ - odpływy osób z bezrobocia do zatrudnienia,

$U N$ - odpływy z bezrobocia do bierności zawodowej.

Porównując stronami równania (3.1) i (3.2), otrzymujemy:

$$
U_{t}-U_{t-1}=(E U+N U)-(U E+U N)
$$

Dodając obustronnie $E N$ (gdzie $E N$ - odpływy z zatrudnienia do bierności zawodowej), po przekształceniach otrzymujemy:

$$
U_{t}=U_{t-1}-h U_{t-1}+s E_{t-1}+N U-U N-E N
$$

gdzie:

$h \quad$ - stopa odpływu z bezrobocia do zatrudnienia $h \in(0,1)$,

$s \quad$ - stopa odpływu z zatrudnienia $s \in(0,1)$,

$E_{t-1}$ - liczba pracujących w okresie $(t-1)$.

Stopa odpływu z bezrobocia do zatrudnienia to stosunek poziomu odpływu $\mathrm{z}$ bezrobocia do zatrudnienia $(U E)$ do poziomu bezrobocia w okresie $(t-1)$, natomiast stopa odpływu z zasobu zatrudnienia to stosunek odpływu z zatrudnienia $(E U+E N)$ do liczby pracujących w okresie $(t-1)$. 
Przyjmujemy, że stopa wzrostu zasobu siły roboczej, czyli stosunek przyrostu zasobu siły roboczej do poziomu zasobu siły roboczej w okresie poprzednim, jest stała i wynosi $n^{3}$. Poziom zasobu siły roboczej w okresie $t$ możemy zatem opisać wzorem:

$$
S_{t}=S_{t-1}(1+n)
$$

gdzie:

$S_{t} \quad$ - zasób siły roboczej w okresie $t$,

$S_{t-1}$ - zasób siły roboczej w okresie $(t-1)$,

$n$ - stopa wzrostu zasobu siły roboczej.

Dzieląc stronami równania (3.4) i (3.5), otrzymujemy:

$$
\frac{U_{t}}{S_{t}}=\frac{U_{t-1}}{S_{t-1}(1+n)}-\frac{h U_{t-1}}{S_{t-1}(1+n)}+\frac{s E_{t-1}}{S_{t-1}(1+n)}+\frac{N U-U N-E N}{S_{t-1}(1+n)}
$$

Po przekształceniach równanie (3.6) możemy zapisać w następujący sposób:

$$
u_{t}=\frac{u_{t-1}}{(1+n)}-\frac{h u_{t-1}}{(1+n)}+\frac{s\left(1-u_{t-1}\right)}{(1+n)}+\frac{z}{(1+n)}
$$

gdzie:

$$
\begin{array}{ll}
u_{t}=\frac{U_{t}}{S_{t}} & - \text { stopa bezrobocia w okresie } t, \\
u_{t-1}=\frac{U_{t-1}}{S_{t-1}} \quad-\text { stopa bezrobocia w okresie }(t-1), \\
z=\frac{N U-U N-E N}{S_{t-1}}-\text { demograficzny składnik bezrobocia. }
\end{array}
$$

Demograficzny składnik bezrobocia pozwala określić znaczenie napływów spoza siły roboczej do bezrobocia i odpływów z zasobu siły roboczej do bierności zawodowej dla wielkości zasobu bezrobocia.

W warunkach stanu stacjonarnego stopa bezrobocia nie ulega zmianie, czyli:

$$
u^{*}=u_{t}=u_{t-1}
$$

gdzie:

$u^{*} \quad$ stopa bezrobocia w warunkach stanu stacjonarnego.

\footnotetext{
${ }^{3}$ Zasób siły roboczej: $S=U+E$; gdzie $U-$ liczba bezrobotnych, $E-$ liczba pracujących.
} 
Podstawiając równanie (3.8) do równania (3.7) po przekształceniach otrzymujemy równanie stopy bezrobocia w warunkach stanu stacjonarnego (zob. Alogoskoufis et al. 1995, s. 13):

$$
u^{*}=\frac{s+z}{s+h+n}
$$

Stopa bezrobocia opisana równaniem (3.9) uwzględnia większość stóp przepływów. Dodatkowo uwzględnia ona zmiany zasobu siły roboczej. $Z$ równania (3.9) wynika, że stopa bezrobocia w warunkach stanu stacjonarnego jest malejącą funkcją stopy odpływu $\mathrm{z}$ bezrobocia $(h)$ i stopy wzrostu zasobu siły roboczej (n) oraz rosnącą funkcją wskaźnika demograficznego (z). Wpływ zmiany stopy odpływu z zatrudnienia $(s)$ na poziom stopy bezrobocia w warunkach stanu stacjonarnego wyznaczonej na podstawie równania (3.9) jest niejednoznaczny. Jeśli $(h+n)>z$, to wzrost stopy odpływu z zatrudnienia spowoduje wzrost stopy bezrobocia w warunkach stanu stacjonarnego. W przeciwnym przypadku wzrost stopy odpływu z zatrudnienia spowoduje spadek stopy bezrobocia $\mathrm{w}$ warunkach stanu stacjonarnego.

Podstawową zaletą tej formuły jest to, że pozwala ona na wyodrębnienie czynników wpływających na bezrobocie równowagi, takich jak: zmiany demograficzne zachodzące na rynku pracy, stopa odpływu z bezrobocia, stopa odpływu z zatrudnienia oraz dynamika zasobu siły roboczej. Niewątpliwą jej wadą jest to, że nie uwzględnia ona jednak wszystkich przepływów siły roboczej. W równaniu (3.9) nie uwzględnia się odpływów z bierności zawodowej do zatrudnienia.

Inną formułę wyznaczania stopy bezrobocia w warunkach stanu stacjonarnego znaleźć można w pracach S. T. Marstona oraz R. G. Ehrenberga, R. S. Smitha (zob. Marston 1976, s. 172; Ehrenberg, Smith 1994, s. 565). Przy wyznaczaniu stopy bezrobocia równowagi założyli oni również, że mamy do czynienia ze stanem stacjonarnym na rynku pracy (steady state). W warunkach steady state napływy do zatrudnienia są równe odpływom z tego zasobu, co możemy zapisać w następujący sposób:

$$
(u e) U+(n e) N=((e u)+(e n)) E
$$

gdzie ${ }^{4}$ :

$N$ - bierni zawodowo,

en - stopa odpływu z zatrudnienia do bierności zawodowej,

ue - stopa odpływu z bezrobocia do zatrudnienia,

eu - stopa odpływu z zatrudnienia do bezrobocia.

\footnotetext{
${ }^{4}$ Pierwsza litera w symbolu stóp przepływów oznacza zasób, z którego jednostki przepływają, zaś druga - zasób, do którego napływają.
} 
W warunkach stanu stacjonarnego napływy do bezrobocia są równe wielkości odpływów z tego zasobu, czyli:

$$
(e u) E+(n u) N=((u e)+(u n)) U
$$

gdzie:

$n u$ - stopa odpływu z bierności zawodowej do bezrobocia, un - stopa odpływu z bezrobocia do bierności zawodowej.

Po przekształceniach równań (3.10)-(3.11) otrzymujemy:

$$
(e u) E+(n u) \frac{((e u)+(e n)) E}{(n e)}=U\left((u e)+(u n)+\frac{(n u)(u e)}{(n e)}\right)
$$

Z równania (3.12) możemy wyznaczyć zasób pracujących $(E)$ :

$$
E=U\left(\frac{u e+u n+\frac{(n u)(u e)}{n e}}{e u+\frac{e u+e n}{n e} n u}\right)
$$

Podstawiając do równania stopy bezrobocia równanie (3.13), mamy:

$$
u=\frac{U}{U+E}=\frac{U}{U+U\left(\frac{u e+u n+\frac{(n u)(u e)}{n e}}{e u+\frac{(e u+e n)}{n e} n u}\right)}
$$

Po przekształceniach równanie (3.14) przyjmuje postać:

$$
u_{s}=\frac{1}{1+\frac{(u e+u n)(n e)+(n u)(u e)}{(e u)(n e+n u)+(e n)(n u)}}
$$

Opisana równaniem (3.15) stopa bezrobocia jest funkcją wszystkich stóp przepływów. W odróżnieniu od formuły (3.9) nie zawiera ona stopy zmian zasobu siły roboczej. Z uwagi na to, że do wyznaczania stopy bezrobocia równowagi w oparciu o równanie (3.15) korzystamy z innych stóp przepływów niż w przypadku równania (3.9), stopy bezrobocia $w$ warunkach stanu stacjonarnego oszacowane w oparciu o równania (3.9) i (3.15) przyjmą różne wartości, jednakże obie powinny charakteryzować się taką samą zmiennością w czasie. 
Opisana równaniem (3.15) stopa bezrobocia w warunkach stanu stacjonarnego jest malejącą funkcją stóp odpływu: z bezrobocia do zatrudnienia (ue), $\mathrm{z}$ bezrobocia do bierności zawodowej (un) oraz z bierności zawodowej do zatrudnienia (ne). Z równania (3.15) wynika ponadto, że stopa bezrobocia $\mathrm{w}$ równowadze $u_{s}$ jest rosnącą funkcją stóp przepływu: $\mathrm{z}$ zatrudnienia do bezrobocia (eu), z zatrudnienia do bierności zawodowej (en) oraz z bierności zawodowej do bezrobocia $(n u)$.

Nieco inną metodę szacunku bezrobocia równowagi w oparciu o przepływy siły roboczej można znaleźć w pracy R. Darby’ego, J. C. Haltiwangera oraz M. Planta (zob. Darby, Haltiwanger, Plant 1985, s. 3-5; Socha, Sztanderska 2000, s. 152-154). Metoda ta pozwala na oszacowanie sektorowych stóp bezrobocia strukturalnego.

Zgodnie z tą metodą przyrost stopy bezrobocia między okresem $t$ a $(t-1)$ $\mathrm{w}$ danej grupie siły roboczej (przy założeniu, że dana grupa siły roboczej jest homogeniczna), możemy opisać równaniem:

$$
\Delta u=u_{t}-\mathrm{u}_{\mathrm{t}-1}
$$

Po przekształceniach równanie (3.16) przyjmuje postać:

$$
\Delta u=\frac{1}{S_{t}} \Delta U-\frac{n}{n+1} u_{t-1}
$$

gdzie:

$n$ - stopa wzrostu zasobu siły roboczej.

Zmiana zasobu bezrobocia $(\Delta U)$ jest równa różnicy między napływami do bezrobocia i odpływami z bezrobocia. Oznaczmy napływy do bezrobocia symbolem $(N)$ zaś prawdopodobieństwo znalezienia pracy lub opuszczenia zasobu siły roboczej symbolem $(\pi)^{5}$. Po podstawieniu do równania (3.17) otrzymujemy:

$$
\Delta u=\frac{1}{S_{t}}\left(N-\pi \mathrm{U}_{\mathrm{t}-1}\right)-\frac{n}{n+1} u_{t-1}
$$

Niech $\Phi=\frac{N}{S_{t}}$, stąd po podstawieniu do równania (3.18) uzyskujemy:

$$
\Delta u=\Phi-\frac{\pi+n}{n+1} u_{t-1}
$$

${ }^{5}$ Napływy do bezrobocia wynoszą: $N=E U+I U$, zaś prawdopodobieństwo znalezienia pracy lub odpływu z zasobu siły roboczej wynosi: $\pi=\frac{U E+U I}{U_{t-1}}$. 
W warunkach stanu stacjonarnego stopa bezrobocia nie zmienia się $(\Delta u=0)$, czyli rozwiązaniem równania (3.19) jest stopa bezrobocia w równowadze (zob. Socha, Sztanderska 2000, s. 153):

$$
u_{i}=\Phi^{*} \frac{\left(1+\gamma^{*}\right)}{\left(\pi^{*}+\gamma^{*}\right)}=\frac{\Phi^{*}}{\bar{\pi}^{*}}
$$

gdzie:

$u_{i} \quad-$ stopa bezrobocia w równowadze,

$\bar{\pi}^{*}=\frac{\pi+\gamma}{1+\gamma}, \Phi-$ stopa napływu do bezrobocia,

$\frac{1}{\bar{\pi}^{*}} \quad-$ oczekiwana długość trwania bezrobocia w długookresowej

$\Phi^{*}, \pi^{*}, \gamma^{*} \quad$ - długookresowe wartości stopy napływu do bezrobocia, prawdopodobieństwa znalezienia pracy lub odpływu z zasobu siły roboczej oraz stopy wzrostu zasobu siły roboczej.

$\mathrm{Z}$ równania (3.20) wynika, że stopa bezrobocia w warunkach stanu stacjonarnego w danej grupie siły roboczej zależy od stopy napływu do bezrobocia, stopy wzrostu zasobu siły roboczej w danej grupie oraz oczekiwanej długości trwania bezrobocia. Sumując sektorowe stopy bezrobocia w równowadze z uwzględnieniem wagi danego sektora w zasobie siły roboczej, otrzymujemy agregatową stopę bezrobocia w równowadze:

$$
u^{A}=\sum\left(\frac{n_{i}}{n}\right) u_{i}
$$

gdzie:

$u^{A}$ - agregatowa stopa bezrobocia $\mathrm{w}$ długookresowej równowadze,

$u_{i}$ - stopa bezrobocia w równowadze w $i$-tej grupie siły roboczej,

$n_{i} \quad$ - liczba aktywnych zawodowo (zasób siły roboczej) w $i$-tej grupie siły roboczej.

W odróżnieniu od prezentowanych powyżej formuł służących do oszacowania stóp bezrobocia w warunkach stanu stacjonarnego, bierze się pod uwagę przeciętny czas trwania bezrobocia. Nie uwzględnia się jednak niektórych przepływów, które zawierają formuły (3.9) oraz (3.15). Ponadto, szacowanie stóp bezrobocia równowagi $\mathrm{w}$ grupach siły roboczej jest utrudnione $\mathrm{z}$ uwagi na dostępność danych statystycznych o przepływach siły roboczej.

Kolejna metoda szacowania stopy bezrobocia w równowadze, oparta na analizie przepływów siły roboczej, została przedstawiona w artykule R. E. Halla (zob. Hall 1979, s. 155-157) ${ }^{6}$. Załóżmy, że w każdym okresie czasu dokładnie $V$ ofert pracy jest oferowanych dla bezrobotnych oraz $U$ bezrobotnych przystępuje do poszukiwania pracy. Jeśli liczbę bezrobotnych oznaczymy literą $U$, to

\footnotetext{
${ }^{6}$ Podobną metodę szacowania bezrobocia równowagi można znaleźć w pracach: M. Darby'ego, J. C. Haltiwangera i M. Planta (1985), R. J. Barro, (1997) oraz Ch. Ramaswami (1983).
} 
szansa znalezienia pracy przez bezrobotnego wynosi $\frac{1}{U}$. Prawdopodobieństwo, że poszukujący pracy bezrobotny nie uzyska żadnej oferty pracy spośród $V$ ofert zgłaszanych w każdym okresie wynosi:

gdzie:

$$
1-f_{l}=\left(\left(1-\frac{1}{U}\right)\right)^{V}=\left[\left(1-\frac{1}{U}\right)^{-U}\right]^{-\frac{V}{U}}
$$

$f_{l}$ - stopa podejmowania pracy.

Stopę podejmowania pracy przez pojedynczego bezrobotnego możemy opisać wzorem ${ }^{7}$ :

$$
f_{l}=1-e^{-\frac{V}{U}}
$$

Zakładamy, że stopa odpływu z zatrudnienia do bezrobocia, definiowana tak jak poprzednio, wynosi $s_{e}$. Wielkość odpływu z zatrudnienia do bezrobocia wynosi: $s_{e} E$. Jak już wspomniano wcześniej, na początku każdego okresu $U$ osób bezrobotnych przystępuje do poszukiwania pracy. Jednak nie wszyscy bezrobotni, którzy podejmują poszukiwania, znajdują pracę. Przyjmijmy, że w każdym okresie $\left(U f_{l}\right)$ osób spośród poszukujących znajduje zatrudnienie, czyli liczba bezrobotnych, którzy nie znajdują pracy i pozostają bezrobotnymi w całym okresie, wynosi $\left[\left(1-f_{l}\right) U\right]$. W warunkach stanu stacjonarnego, jak już wspomniano wcześniej, napływy do bezrobocia są równe odpływom z bezrobocia, co możemy opisać równaniem:

$$
U=\left(1-f_{l}\right) U+s_{e} E
$$

gdzie:

$\left(1-f_{l}\right) U$ - liczba osób, które pozostają bezrobotnymi,

$s_{e} E \quad-$ odpływ z zatrudnienia do bezrobocia.

$\mathrm{Z}$ równania (3.24) wynika, iż stosunek liczby bezrobotnych do liczby pracujących wynosi: $\frac{U}{E}=\frac{s_{e}}{f_{l}}$. Stopę bezrobocia w równowadze (definiowaną jako odsetek pozostających bez pracy w całym okresie) możemy zapisać wzorem:

$$
u^{r}=\frac{\left(1-f_{l}\right) U}{E+\left(1-f_{l}\right) U}=\frac{s_{e}}{s_{e}+\frac{f_{l}}{1-f_{l}}}
$$

${ }^{7} \operatorname{Dla} U \rightarrow+\infty \lim \left[\left(1-\frac{1}{U}\right)^{-U}\right]^{-\frac{V}{U}}=e^{-\frac{V}{U}}$ 
$\mathrm{Z}$ równania (3.25) wynika, że stopa bezrobocia (w równowadze) $\left(u^{r}\right)$ zależy od stopy podejmowania pracy oraz stopy odpływu z zatrudnienia do bezrobocia. Wzrost (spadek) stopy odpływu z zatrudnienia powoduje wzrost (spadek) stopy bezrobocia w równowadze. Natomiast wzrost (spadek) stopy podejmowania pracy prowadzi do spadku (wzrostu) naturalnej stopy bezrobocia.

Inną jeszcze formułę wyznaczania bezrobocia równowagi w oparciu o przepływy siły roboczej znaleźć można w pracy M. Gärtnera (zob. Gärtner 1997, s. 126). Rys. 3.1 przedstawia zmodyfikowany schemat przepływów siły roboczej zaproponowany przez tego badacza.

Stopy odpływu z zatrudnienia oraz podejmowania pracy przez osoby bezrobotne, czyli stopy odpływu z bezrobocia do zatrudnienia, zostały zdefiniowane już wcześniej. Stopa odpływu z zasobu siły roboczej $(q)$ to stosunek odpływu z zasobu siły roboczej do bierności zawodowej do zasobu siły roboczej w okresie poprzednim. Natomiast stopa napływu do zasobu siły roboczej to stosunek wielkości napływu do zasobu siły roboczej w danym okresie do zasobu siły roboczej w okresie poprzednim. Stopa napływu na rynek pracy osób, które znajdują natychmiast zatrudnienie $\left(e_{u}\right)$, to część (odsetek) łącznego napływu do zasobu siły roboczej z bierności zawodowej. Wskazuje ona, jaka część osób napływających na rynek pracy znajduje zatrudnienie. Kolejna wielkość $-q_{u}$, czyli stopa odpływu z zasobu siły roboczej bezrobotnych, to część (odsetek) łącznego odpływu z zasobu siły roboczej. Stopa ta informuje, jaką część łącznego odpływu z zasobu siły roboczej stanowią osoby bezrobotne.

W warunkach stanu stacjonarnego napływy do zatrudnienia, bezrobocia i bierności zawodowej są równe odpływom $\mathrm{z}$ tych zasobów. Równowagę napływów do bezrobocia z odpływami z bezrobocia możemy opisać wzorem:

$$
e_{u} e S+s L=q_{u} q S+s U
$$

Dzieląc obustronnie równanie (3.26) przez zasób siły roboczej $(S)$, otrzymujemy:

$$
e_{u} e+s(1-u)=q_{u} q+s u
$$

gdzie:

$u$ - stopa bezrobocia.

Stopa bezrobocia $(u)$ w równaniu (3.27) jest stopą bezrobocia odpowiadającą stanowi stacjonarnemu. Wyznaczając $(u)$ z równania (3.27), otrzymujemy formułę stopy bezrobocia w warunkach stanu stacjonarnego:

$$
u^{R}=\frac{s}{s+f}+\frac{e_{u} e-q_{u} q}{s+f}
$$


Opisana równaniem (3.28) stopa bezrobocia w warunkach stanu stacjonarnego w odróżnieniu od formuł opisanych wcześniej, za wyjątkiem formuły opisanej równaniem (3.15), uwzględnia stopy napływów do zasobu siły roboczej i odpływów z tego zasobu. Ponadto, możemy stwierdzić, że formuła zaproponowana przez M. G. Gärtnera jest zbliżona do formuły wyprowadzonej przez S. T. Marstona (1976) oraz R. G. Ehrenberga i R. S. Smitha (1994) oraz formuły R. E. Halla (1979).

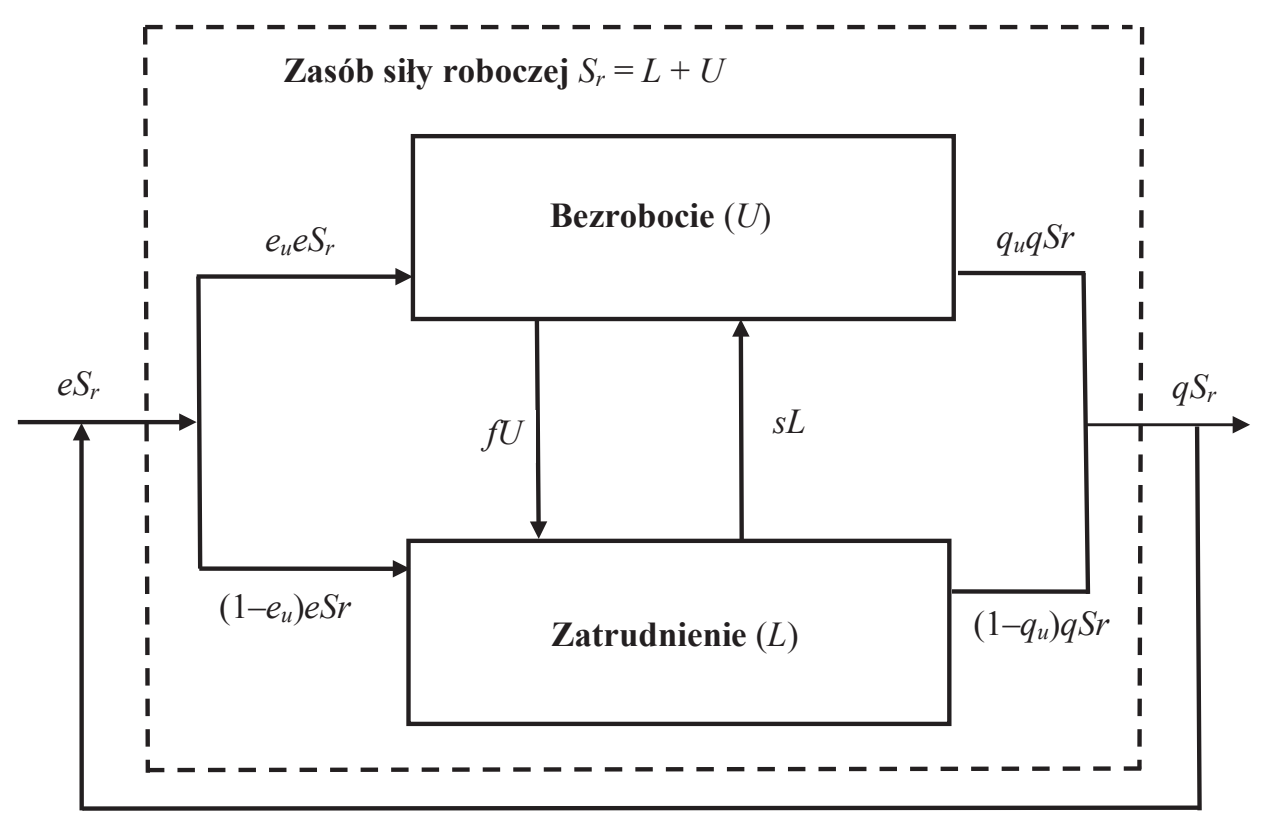

Rys. 3.1. Przepływy siły roboczej

$s$ - stopa odpływu z zatrudnienia, $f$ - stopa podejmowania pracy przez osoby bezrobotne, $q$ - stopa odpływu z zasobu siły roboczej, $e$ - stopa napływu do zasobu siły roboczej, $e_{u}$ - stopa napływu na rynek pracy osób, które znajdują natychmiast zatrudnienie (np. absolwenci), $q_{u}$ - stopa odpływu z zasobu siły roboczej bezrobotnych.

Źródło: Gärtner 2006, s. 163.

Z uwagi na to, że przy obliczaniu stopy bezrobocia w warunkach stanu stacjonarnego wykorzystywane są różne stopy przepływów, otrzymane wyniki mogą różnić się między sobą. Jednakże stopy bezrobocia oszacowane przy pomocy dotychczas wyprowadzonych wzorów powinny się charakteryzować taką samą tendencją zmian w czasie.

Wypada zauważyć, że podstawową zaletą metod szacowania bezrobocia równowagi w oparciu o przepływy siły roboczej jest łatwość ich zastosowania.

$\mathrm{W}$ przypadku każdej z omawianych metod posługujemy się jednorodnymi danymi o przepływach siły roboczej. Do wyznaczania wielkości bezrobocia 
w warunkach stanu stacjonarnego nie musimy dysponować danymi o wolnych miejscach pracy, płacach czy inflacji tak, jak w przypadku pozostałych metod. Metody oparte na przepływach siły roboczej umożliwiają również analizy przyczyn zmian stopy bezrobocia w warunkach stanu stacjonarnego, czego nie możemy uczynić w przypadku metod opartych na krzywej Phillipsa czy krzywej Beveridge'a.

Podstawową zaś wadą szacowania bezrobocia równowagi w oparciu o metody przepływów siły roboczej jest ich wrażliwość na zmiany koniunktury gospodarczej. Oznacza to, że uzyskane oszacowania nie spełniają wystarczająco wymagań w poznawaniu samego bezrobocia naturalnego (zob. Góra, Walewski 2002, s. 37).

Jak już bowiem wspomniano, przy wyznaczaniu stóp bezrobocia w oparciu o przepływy siły roboczej wykorzystuje się różne stopy przepływów, w związku z tym wyniki oszacowań stopy bezrobocia w oparciu o różne formuły mogą się różnić i to znacznie między sobą. Wadą metody przepływów jest również fakt, że przy wyznaczaniu stopy bezrobocia w równowadze pomijamy inflację.

\subsubsection{Metody oparte na krzywej Phillipsa}

Metody odwołujące się do koncepcji krzywej Phillipsa stosowane są najczęściej w analizach ekonomicznych dotyczących bezrobocia równowagi ${ }^{8}$. Podstawową zaletą tych metod jest to, że oszacowania stopy bezrobocia równowagi są wyznaczane przy założeniu stabilnego poziomu inflacji, czyli tym samym uwzględniają podstawowe oczekiwania wobec teorii bezrobocia równowagi.

Krótkookresowa krzywa Phillipsa opisuje zależność między tempem wzrostu cen a stopą bezrobocia. W analizach ekonometrycznych dotyczących NAIRU wykorzystywana jest zwykle rozszerzona krzywa Phillipsa (w wersji płacowej lub cenowej). Krzywą Phillipsa w wersji cenowej możemy opisać wzorem (zob. Gordon 1996, s. 9):

$$
\pi_{t}=\alpha(L) \pi_{t-1}+\beta(L)\left(u_{t}-u^{*}\right)+\delta(L) z_{t}+\varepsilon_{t}
$$

gdzie:

$\pi_{t} \quad$ - stopa inflacji w okresie $t$,

$\pi_{t-1}-$ stopa inflacji w okresie $t-1$,

$u_{t}$ - stopa bezrobocia,

$u^{*}-$ stały poziom bezrobocia równowagi,

${ }^{8}$ Pokrewnymi metodami - do metod odwołujących się do rozszerzonej krzywej Phillipsa - są metody wykorzystujące teoretyczną koncepcję krzywej płac. Teoretycznych podstaw krzywej płac upatruje się w modelach nowej ekonomii keynesowskiej, a w szczególności w modelach przetargów płacowych, modelach niepisanych kontraktów płacowych oraz w największym stopniu w teorii płacy wydajnościowej (efficiency wage theory) (zob. Rogut 2007, s. 20). Krzywa płac opisuje ujemną zależność między stopą bezrobocia a poziomem płac w gospodarce (zob. Blanchflower, Oswald 1995, s. 493). 
$z_{t} \quad$ - wektor zmiennych reprezentujących wpływ szoków podażowych na poziom inflacji,

$\alpha(L), \beta(L), \delta(L)$ - wielomianowe operatory opóźnień,

$\varepsilon_{t} \quad-$ składnik losowy.

Szoki popytowe $\mathrm{w}$ tym równaniu są opisane przez różnicę między rzeczywistą stopą bezrobocia a NAIRU. W sytuacji, gdy suma parametrów $\alpha(L)$ będzie równa 1 oraz faktyczna stopa bezrobocia będzie równa stopie bezrobocia równowagi, to przy braku szoków podażowych inflacja będzie stała. Stopa bezrobocia NAIRU może być szacowana w oparciu o równanie (3.29a):

$$
N A I R U=u^{*}+\delta(1) z_{t} / \beta(1)
$$

W przypadku, gdy nie występują szoki podażowe (to znaczy gdy $z_{t}=0$ ), stopa bezrobocia NAIRU będzie równa $u^{*}$. W tym przypadku oszacowanie NAIRU można wyznaczyć w oparciu o oszacowania stałej następującego równania (zob. Fitzenberger, Franz, Bode 2007, s. 3):

$$
\pi_{t}=d+\alpha(L) \pi_{t-1}-\beta(L) u_{t}+\varepsilon_{t}
$$

gdzie:

$d \equiv \beta(1) u^{*}$.

Oszacowana w oparciu o równanie (3.29b) stopa bezrobocia równowagi to tzw. no-shock NAIRU, czyli stopa bezrobocia równowagi w sytuacji, gdy nie występują szoki podażowe.

Założenie o stałości NAIRU było przyjmowane w początkowych próbach estymacji NAIRU w oparciu o poszerzoną krzywą Phillipsa (zob. Estrella, Miszkin 1998, s. 5). Założenie o stałości naturalnej stopy bezrobocia nie znajduje potwierdzenia ani w teorii, ani w badaniach empirycznych. Wielu badaczy, korzystając z nowoczesnych narzędzi statystycznych, koncentruje się więc na wyznaczaniu zmiennej w czasie stopy bezrobocia równowagi.

W przypadku estymacji modeli zakładających zmienność stopy bezrobocia NAIRU w czasie, $u^{*}$ w równaniu (3.29a) jest zastępowane przez $u_{t}^{*}$. Poziom $u_{t}^{*}$ możemy opisać wzorem:

$$
u_{t}^{*}=u_{t-1}^{*}+\eta_{t}
$$

gdzie:

wartość oczekiwana: $E\left(\eta_{t}\right)=0$ oraz wariancja $\operatorname{var}\left(\eta_{t}\right)=\sigma^{2}$.

Dla $\sigma=0$ uzyskujemy stałą wartość NAIRU, natomiast w przypadku gdy $\sigma>0$, otrzymujemy zmienną w czasie wartość NAIRU. Równanie (3.29c) to tzw. filtr Kalmana, który modeluje NAIRU jako proces błądzenia losowego. Należy 
jednak zwrócić uwagę, iż wykorzystanie filtru Kalmana jest krytykowane w literaturze ekonometrycznej (zob. Kelm 2009, s. 99). Zastosowanie tej metody wymaga arbitralnego ustalenia wartości początkowej NAIRU oraz założenia odnośnie procesu generującego NAIRU.

W zależności od tego, czy estymujemy płacową czy cenową krzywą Pillipsa, otrzymujemy stopę bezrobocia NAWRU lub NAIRU. NAWRU (Non-Accelerating Wage Rate of Unemployment) to stopa bezrobocia nieprzyspieszająca wzrostu płac. Stopa bezrobocia NAWRU nie jest tożsama z NAIRU, jednakże z uwagi na to, że obie są nieobserwowalne, stosowane są one zamiennie w analizach empirycznych (zob. Gradzewicz, Kolasa 2004, s. 14). Po raz pierwszy jako miara stopy bezrobocia strukturalnego została ona zaproponowana przez J. Elmeskova i M. MacFarlanda (1993) oraz J. Elmeskova (1994).

Zmiany poziomu NAIRU mogą być rezultatem występowania efektu histerezy bezrobocia. Uwzględnienie efektu histerezy wymaga poszerzenia równania (3.29c) (zob. Fitzenberger, Franz, Bode 2007, s. 4):

$$
\begin{gathered}
u_{t}^{*}=\bar{u}+\varphi\left(u_{t-1}-\bar{u}\right)+\mu_{t} \\
\mu_{t} \sim N\left(0, \sigma_{\mu_{t}}^{2}\right)
\end{gathered}
$$

gdzie:

$\bar{u}$ - poziom NAIRU w warunkach stanu stacjonarnego lub NAIRU równowagi, $u_{t}^{*}$ - współczesny poziom NAIRU (krótkookresowa stopa bezrobocia NAIRU).

Po podstawieniu równania (3.29d) do równania (3.29) oraz po przekształceniach otrzymujemy:

$$
\pi_{t}=\alpha(L) \pi_{t-1}-\beta(L)\left[(1-\phi)\left(u_{t}-\bar{u}\right)+\phi \Delta u_{t}+\delta(L) z_{t}+\varepsilon_{t}+\beta(L) \mu_{t}\right.
$$

W przypadku gdy $\phi=0$, efekt histerezy nie występuje. Natomiast w przypadku gdy $\phi=1$, mamy do czynienia z pełnym efektem histerezy.

Metody szacowania bezrobocia równowagi oparte na krótkookresowej krzywej Phillipsa skupiają się na analizie zależności w krótkim okresie. Pomija się w nich natomiast analizy zależności długookresowych, a to ma wpływ na oceny parametrów $\alpha$ i $\beta$ w równaniach (3.29a)-(3.29e).

W literaturze znaleźć można bardzo wiele metod szacunków NAIRU. O. Blanchard i L. F. Katz w swoim opracowaniu korzystają z krótkookresowej krzywej Phillipsa poszerzonej o oczekiwania adaptacyjne (zob. Blanchard, Katz 1996, s. 15-23). W swoich analizach wykorzystują oni następujący układ równań:

$$
\Delta p_{t}=\alpha_{p}+\Delta w_{t}+\varepsilon_{p t}
$$




$$
\Delta w_{t}=\alpha_{w}+\Delta p_{t-1}-\beta u_{t}+\varepsilon_{w t}
$$

gdzie:

$p_{t} \quad$ - logarytm poziomu cen,

$\Delta p_{t} \quad$ - stopa inflacji,

$\Delta w_{t} \quad$ - stopa wzrostu płac,

$u_{t} \quad$ - stopa bezrobocia,

$\alpha_{p}, \alpha_{w}-$ stałe,

$\varepsilon_{p t}, \varepsilon_{w t}$ - standardowe błędy szacunku.

Po podstawieniu równania (3.30) do równania (3.31) otrzymujemy postać równania, którą poddano estymacji :

$$
\Delta p_{t}=\alpha+\Delta p_{t-1}-\beta u_{t}+\varepsilon_{t}
$$

Estymacja parametrów strukturalnych równania (3.32) pozwala na oszacowanie stopy bezrobocia równowagi.

$\mathrm{Z}$ kolei D. Irack w swoim opracowaniu estymuje następujący układ równań (zob. Irack 2000, s. 7) ${ }^{10}$ :

$$
\left\{\begin{array}{l}
\pi_{t}=c_{1} \pi_{t-1}+c_{2} \pi_{t-2}+\left(1-c_{1}-c_{2}\right) \pi_{t-3}+c_{3}\left(U_{t}-\bar{U}_{t}\right)+\sum \alpha_{i} z_{i t}+\varepsilon_{t}^{\pi} \\
\bar{U}_{t}=\bar{U}_{t-1}+\varepsilon_{t}^{U}
\end{array}\right.
$$

gdzie:

U - stopa bezrobocia,

$\pi \quad-$ stopa inflacji,

$\bar{U} \quad-$ stopa bezrobocia NAIRU,

$z_{i} \quad-$ wstrząsy podażowe.

$c_{1}, c_{2}, c_{3}-$ parametry strukturalne modelu.

Do oszacowania układu równań (3.33) konieczne jest wyspecyfikowanie pierwszego równania. W równaniu tym występuje wielkość nieobserwowalna NAIRU, co oznacza konieczność aproksymacji wyjściowego poziomu NAIRU (np. w oparciu o filtr Hodricka-Prescotta lub filtr Kalmana).

${ }^{9}$ Rozwiązując równanie (3.32) przy założeniu, że oczekiwania inflacyjne są spełnione, otrzymujemy stopę bezrobocia NAIRU: $u^{*}=\frac{\alpha}{\beta}$. Podobne rozwiązanie uzyskamy, jeśli równania (3.30) i (3.31) zapiszemy następująco (zob. Layard, Nickell, Jackman 2005, s. 13):

$$
\begin{gathered}
p=w+\delta_{0}-\delta_{1} u \\
w=p^{e}+\varphi_{0}-\varphi_{1} u
\end{gathered}
$$

gdzie: $p$ - poziom cen, $w$ - płace, $p^{e}$ - oczekiwana stopa inflacji, $u$ - stopa bezrobocia.

${ }^{10}$ Podobny układ równań estymuje w swoim opracowaniu Gordon (1996). 
Należy zwrócić uwagę, iż poprawność szacunków NAIRU w oparciu o krzywą Phillipsa uwarunkowana jest przez takie czynniki, jak (zob. Socha, Sztanderska 2000, s. 147-148):

- dokładność danych o płacach i inflacji,

- założenie odnośnie typu oczekiwań (adaptacyjne, racjonalne) i zachowań pracobiorców,

- wybór właściwego modelu ekonometrycznego oraz precyzja oszacowań parametrów.

Jak dowodzą badania empiryczne, poziom szacunków NAIRU zależy od użytych w modelu deflatorów. D. Staiger, J. H. Stock, M. W. Watson w zależności od użytych deflatorów uzyskali szacunki NAIRU dla 1990 r. mieszczące się w przedziale 5,1\% do 7,7\% (zob. Staiger, Stock, Watson 1996, s. 2) ${ }^{11}$. Również J. Gordon (1996) w zależności od użytych deflatorów uzyskał różne szacunki NAIRU.

Dobór właściwego modelu ekonometrycznego oraz jego specyfikacja ma zasadnicze znaczenie dla poprawności szacunków NAIRU. Zła specyfikacja modelu może prowadzić do uzyskania korelacji pozornych.

Zaawansowane techniki ekonometryczne znalazły zastosowanie do szacunków NAIRU (NAWRU). W ostatnich latach w badaniach empirycznych bezrobocia równowagi powszechne zastosowanie znalazły modele wektorowej autoregresji (VAR) (zob. Kelm 2009, s. 99):

$$
y_{(m) t}=\sum_{s=1}^{S} \Pi_{s} y_{(m) t-s}+u_{(m) t}
$$

gdzie:

$y_{(m) t}=\left[y_{1 t}, y_{2 t}, \ldots, y_{M t}\right]^{\prime}-$ wektor obserwacji $M$ zmiennych w okresie $t$, $\Pi_{s}=\left[\pi_{i, j}^{(s)}\right]-$ macierz parametrów w wymiarach $M \times M$, $u_{(m) t}=\left[u_{1 t}, u_{2 t}, \ldots, u_{M t}\right], u_{(m) t}: N I(0, \Sigma), i, j, m=1, \ldots, M, s=1, \ldots, S, t=1, \ldots, T$.

Zaletą modeli VAR jest to, że ich konstrukcja nie wymaga przyjmowania apriori jakichkolwiek arbitralnych założeń odnośnie modelu teoretycznego. W procesie identyfikacji modelu najważniejsze znaczenie mają właściwości statystyczne danych, a nie arbitralne decyzje badacza (zob. Kuczyński, Strzała 2006, s. 315). Krzywa Phillipsa w modelach VAR nie stanowi metodologicznego założenia, lecz pełni tylko funkcję hipotezy, którą można w trakcie badań empirycznych potwierdzić albo odrzucić.

Równanie (3.34) przekształca się do modelu średniej ruchomej (ang. moving average model - w skrócie MA) oraz modelu wektorowej korekty błędem (ang. vector error correction - w skrócie VEC).

\footnotetext{
${ }^{11}$ Wszystkie wyniki uzyskano w przedziale istotności 95\%.
} 
W przypadku modeli opartych na średniej ruchomej, równanie (3.34) przekształca się do postaci (zob. Kelm 2009, s. 100):

$$
y_{(m) t}=C y_{(m) 0}+C \sum_{i=1}^{t} u_{(m) i}+S_{t}
$$

gdzie:

C - pewna macierz,

$y_{(m) 0}-$ wektor początkowych wartości zmiennych systemu,

$S$ - stacjonarny proces stochastyczny.

Modele oparte na średniej ruchomej mogą być wykorzystane do szacowania NAIRU dopiero po strukturalizacji. Strukturalizacja polega na znalezieniu macierzy B, która wiąże szoki $\varepsilon_{t}$ (mające interpretację ekonomiczną) ze składnikami losowymi $u_{t}$ :

$$
u_{m(t)}=\mathrm{B} \varepsilon_{m(t)}
$$

Wadą modeli opartych średniej ruchomej jest to, że badacz sam arbitralnie ustala listę szoków oddziałujących na zmienne modelu (3.34) oraz arbitralnie ustala restrykcje na macierz, która wiąże szoki ze składnikiem losowym $u_{t}$.

Powyższe problemy można rozwiązać poprzez wykorzystanie modelu wektorowej korekty błędem. Modele wektorowej korekty błędem umożliwiają analizę zmiennych niestacjonarnych zintegrowanych w stopniu pierwszym (w przypadku zmiennej zintegrowanej w stopniu pierwszym stacjonarny jest jej pierwszy przyrost). Ponadto, model VEC pozwala na jednoczesną analizę związków równowagi dynamicznej, estymację parametrów dostosowań do ścieżek równowagi oraz parametrów krótkookresowych. W ramach modelu wektorowej korekty błędem można przeprowadzić statystyczną weryfikację hipotez oraz nadać wektorom kointegrującym interpretację zgodną z przyjętym modelem teoretycznym.

\subsubsection{Metody oparte na krzywej Beveridge'a}

Trzecia grupa metod szacowania bezrobocia równowagi opiera się na koncepcji krzywej Beveridge'a. Krzywa Beveridge'a opisuje ujemną odwrotną zależność między stopą wolnych miejsc pracy a stopą bezrobocia (zob. rys. 3.2). Ma ona ujemne nachylenie, ponieważ wzrost efektywnego popytu i produkcji prowadzi do wzrostu popytu na pracę. Wolne miejsca pracy stanowią część składową popytu na pracę, dlatego wzrost produkcji oraz efektywnego popytu prowadzi również do wzrostu liczby wolnych miejsc pracy (zob. Creedy 1981, s. 102).

Ruch po krzywej Beveridge'a oznacza cykliczne zmiany w łącznym popycie na pracę. Spadek popytu na pracę prowadzi do zmniejszenia liczby wolnych miejsc pracy (jak i stopy wolnych miejsc pracy) i w konsekwencji do wzrostu 
stopy bezrobocia, co znajduje wyraz w przesunięciu po krzywej Beveridge'a w prawo (np. z punktu A do B na rys. 3.2) (zob. Daly, Hobijn, Şahin, Valletta 2012, s. 151). Wzrost (spadek) efektywności procesu dopasowań przesuwa krzywą Beveridge'a w lewo (w prawo).

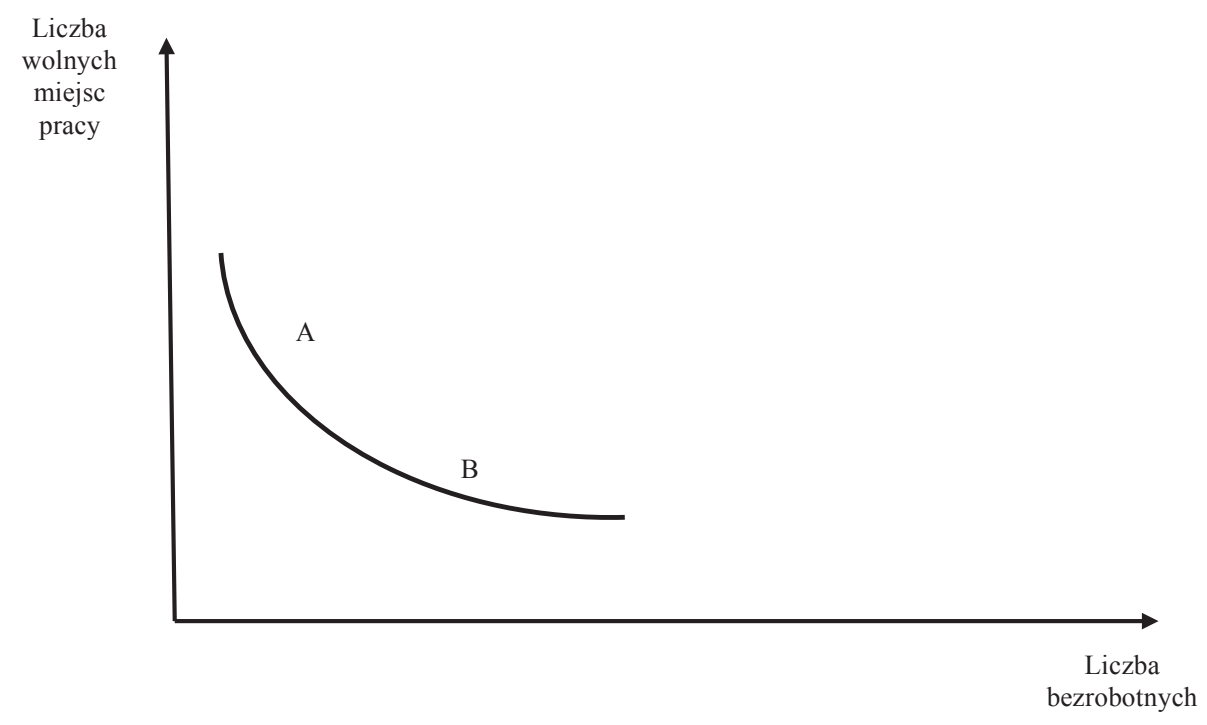

Rys. 3.2. Krzywa Beveridge'a

Źródło: opracowanie własne na podstawie: Daly, Hobijn, Şahin, Valletta 2012, s. 151.

$\mathrm{Z}$ uwagi na to, że metoda ta nie znalazła zastosowania w analizach bezrobocia równowagi w Polsce zostanie zaprezentowana w wersji skróconej. Zgodnie $\mathrm{z}$ tą koncepcją bezrobocie występujące $\mathrm{w}$ warunkach równowagi na rynku pracy (utożsamianej w przypadku krzywej Beveridge'a z równością liczby bezrobotnych i liczby wolnych miejsc pracy) to bezrobocie strukturalne (zob. Socha, Sztanderska 2000, s. 150). Nadwyżka liczby bezrobotnych nad liczbą wolnych miejsc pracy to bezrobocie cykliczne. Różnica między faktycznym bezrobociem a bezrobociem cyklicznym, czyli bezrobocie strukturalne, może być traktowana jako poziom bezrobocia $\mathrm{w}$ warunkach równowagi na rynku pracy (czyli równowagi między liczbą bezrobotnych i liczbą wolnych miejsc pracy), jeśli globalne bezrobocie jest większe od łącznej sumy wolnych miejsc pracy. Różnica między bezrobociem faktycznym a cyklicznym (czyli strukturalny komponent bezrobocia) może być traktowana jako bezrobocie globalne, gdy liczba wolnych miejsc pracy jest większa od liczby bezrobotnych.

Szacowanie bezrobocia równowagi w oparciu o koncepcję krzywej Beveridge'a na gruncie empirycznym sprowadza się do estymacji parametrów funkcji dopasowań, a następnie do obliczania stopy bezrobocia w równowadze, czyli stopy 
bezrobocia odpowiadającej równowadze liczby bezrobotnych i wolnych miejsc pracy (punkt ten znajduje się na linii wychodzącej z początku układu współrzędnych, nachylonej pod kątem $45^{\circ}$ ).

W opracowaniu B. Petrongolo, C. Pissarides (2001) można znaleźć obszerne analizy wyników estymacji funkcji dopasowań. $Z$ ich badań wynika, że najczęściej spotykaną specyfikacją funkcji dopasowań jest funkcja Cobb-Douglasa o stałych efektach skali (zob. Petrongolo, Pissarides 2001, s. 424-425).

Niestety, nie tylko w warunkach polskich, ale również w innych krajach, z uwagi na jakość danych statystycznych o wolnych miejscach pracy, szacunki stóp bezrobocia w równowadze przy wykorzystaniu tej metody mogą być znacznie ujemnie obciążone. Do urzędów pracy dociera bowiem tylko część informacji o wolnych miejscach pracy. W efekcie współczynnik kierunkowy linii pomocniczej ilustrującej równość wolnych miejsc pracy i liczby bezrobotnych jest zawsze mniejszy od 1. Aby wyznaczyć stopę bezrobocia równowagi, musi być oszacowana wartość współczynnika kierunkowego tej linii. Precyzja szacunków bezrobocia równowagi w oparciu o krzywą Beveridge'a zależy również od liczby szoków, jakie miały miejsce w danej gospodarce.

\subsubsection{Metody oparte na szacunkach produkcji potencjalnej}

Ostatnia z metod szacowania bezrobocia równowagi opiera się na szacunkach wielkości produkcji potencjalnej. W literaturze ekonomicznej znaleźć można różne definicje produktu potencjalnego. Według A. Okuna produkt potencjalny to maksymalny poziom produkcji, jaki można wytworzyć w gospodarce przy pełnym zatrudnieniu. Pełne zatrudnienie jest traktowane jako taki poziom, który nie wywołuje presji inflacyjnej (zob. Okun 1962, s. 98).

Według innego ujęcia produkcja potencjalna to średnia wartość PKB w cyklu koniunkturalnym, oczyszczona z wpływu wahań cyklicznych (zob. Wojtyna 2003, s. 4; Józefiak, Krajewski, Mackiewicz 2006, s. 108).

Ze względu na to, że produkt potencjalny jest wielkością nieobserwowalną, tak samo jak stopa bezrobocia równowagi, nie istnieje jednoznaczny, w pełni akceptowany przez wszystkich badaczy sposób jego wyznaczania.

Metody szacowania produktu potencjalnego odwołujące się do definicji zaproponowanej przez Okuna opierają się na wykorzystaniu funkcji produkcji. Przy okazji wyznaczania produktu potencjalnego wyznaczamy potencjalną wielkość nakładów pracy. Potencjalna wielkość nakładów pracy jest określona przez poziom naturalnej stopy bezrobocia, która z kolei jest najczęściej utożsamiana ze stopą bezrobocia nieprzyśpieszającą wzrostu płac (NAWRU). Aby oszacować NAWRU, należy z faktycznej stopy bezrobocia wyodrębnić bezrobocie cykliczne oraz bezrobocie równowagi (rzeczywista stopa bezrobocia jest równa sumie stopy bezrobocia cyklicznego oraz naturalnej stopy bezrobocia). 
Bezrobocie cykliczne jest silnie powiązane z tempem zmiany płac. Można je oszacować w ramach omawianych wcześniej metod estymacji płacowej krzywej Phillipsa.

Alternatywnym sposobem obliczania naturalnej stopy bezrobocia w oparciu o wyznaczanie produktu potencjalnego jest zastosowanie metod statystycznych (np. filtru Hodricka-Prescotta). Bezrobocie równowagi jest tutaj trendem rzeczywistej stopy bezrobocia. Dokładność szacunków bezrobocia równowagi jest wątpliwa.

Kolejna metoda obliczenia bezrobocia naturalnego w oparciu o szacunki produktu potencjalnego wykorzystuje prawo Okuna. Naturalna stopa bezrobocia jest wyznaczana na podstawie analizy odchyleń rzeczywistego PKB od produktu potencjalnego (Socha, Sztanderska 2000, s. 151). Należy zwrócić uwagę, że stopa bezrobocia równowagi jest przy zastosowaniu tej metody wielkością wynikową, zaś produkt potencjalny jest traktowany jako trend PKB (najczęściej oblicza się go za pomocą metod statystycznych - czyli przy wykorzystaniu różnego rodzaju filtrów statystycznych) (zob. Krajewski 2006, s. 96-111).

Dokładność szacunków stopy bezrobocia równowagi w oparciu o metody oparte na szacunkach produktu potencjalnego jest także wątpliwa z uwagi na to, że do wyznaczania jednej wielkości nieobserwowalnej (jakim jest naturalna stopa bezrobocia) korzysta się z szacunków innej wielkości nieobserwowalnej (jaką jest produkt potencjalny).

Przedstawione w tym punkcie opracowania metody szacowania bezrobocia równowagi, z uwagi na odmienne założenia oraz metodę szacowania, prowadzą do uzyskania różnych rezultatów. Nawet w obrębie poszczególnych metod szacunki bezrobocia równowagi mogą być znacząco różne. Kluczowe znaczenie dla jakości uzyskanych wyników mają jakość danych statystycznych oraz długość szeregów czasowych.

\subsection{Szacunki bezrobocia równowagi dla wybranych krajów Europy Środkowo-Wschodniej}

Przyjrzyjmy się również - dla celów porównawczych - wynikom estymacji NAIRU dla Polski i grupy krajów Europy Środkowo-Wschodniej przeprowadzonej przez M. Camarero, J. Carrion-i-Silvestre, C. Tamarit (2005). Analizy podjęte w tym opracowaniu miały na celu weryfikację hipotezy o występowaniu efektu histerezy w grupie 10 krajów przyjętych do UE w 2004 r. Pominięto tutaj oszacowania dla Malty, która nie jest zaliczana do krajów Europy Środkowo-Wschodniej.

Autorzy opracowania korzystają z danych miesięcznych o stopach bezrobocia EUROSTATU. Analizy przeprowadzono w okresie od stycznia 1991 r. do listopada 2003 r. Z uwagi na to, iż w modelu ekonometrycznym przyjęto 12-miesięczny 
okres opóźnień, szacunki NAIRU obejmują okres od stycznia 1992 r. do listopada $2003 \mathrm{r}$.

W modelu wykorzystano tzw. podejście jednowymiarowe (univariate approach). W opracowaniu estymacji poddano równanie w postaci (zob. Camarero, Carrion-i-Silvestre, Tamarit 2005, s. 8):

$$
U_{t}-\bar{U}_{t}=\beta(L)\left(U_{t-1}-\bar{U}_{t-1}\right)+\varepsilon_{t}
$$

gdzie:

$\bar{U}_{t}=\bar{U}_{i}$ dla $T_{b, i-1}<t \leq T_{b, i}$,

$U$ - stopa bezrobocia,

$\beta(L)$ - dynamika,

$T_{b, i}$ - punkt szczególny (break point).

Punkty szczególne (break points) to punkty czasowe, w których zachodziły ważne zmiany w analizowanych gospodarkach. Oszacowano je w oparciu o metody statystyczne.

Tabela 3.1. Przedziały czasowe, w których dokonano estymacji NAIRU w poszczególnych krajach Europy Środkowo-Wschodniej

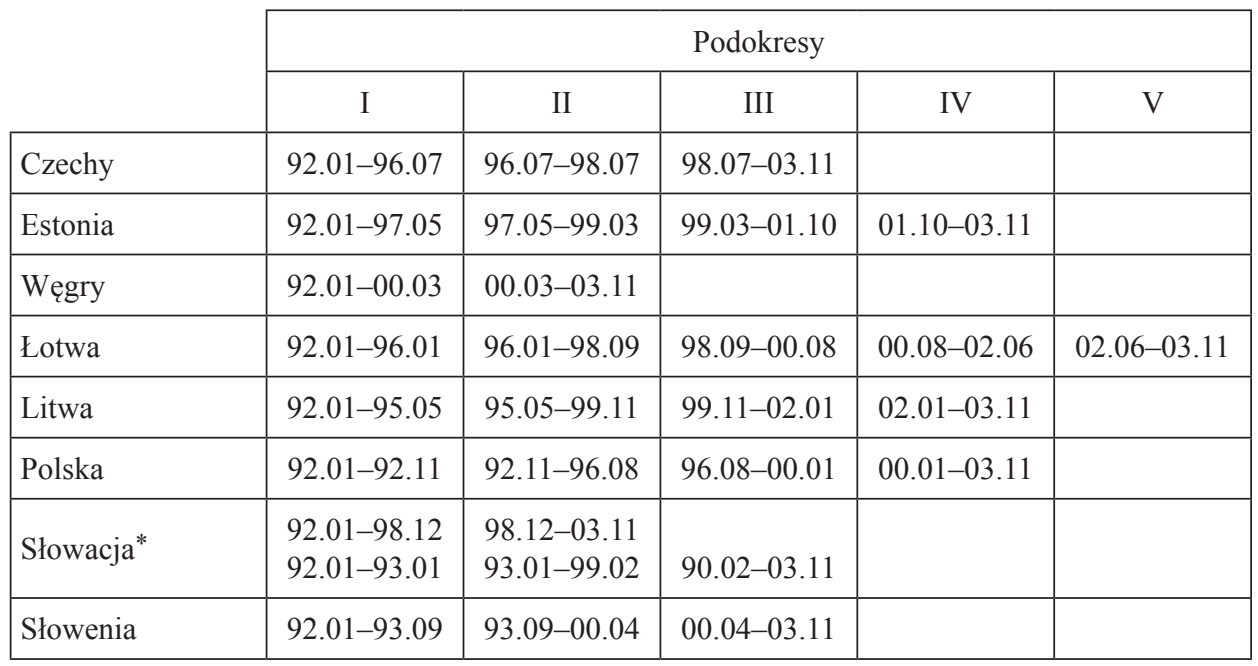

* dla wszystkich krajów punkty szczególne (break points) wyznaczono przy poziomie istotności 0,05 , natomiast dla Słowacji dla poziomów istotności 0,05 (pierwszy wiersz) oraz 0,1 (drugi wiersz).

Źródło: opracowanie własne na podstawie: Camarero, Carrion-i-Silvestre, Tamarit 2005, s. 21. 
Tabela 3.2. Oszacowania NAIRU dla krajów Europy Środkowo-Wschodniej w latach 1992-2003 (estymacja punktowa)

\begin{tabular}{|l|c|c|c|c|c|}
\cline { 2 - 6 } \multicolumn{1}{c|}{} & \multicolumn{5}{c|}{ Podokresy } \\
\cline { 2 - 6 } \multicolumn{1}{c|}{} & I & II & III & IV & V \\
\hline Czechy & 3,25 & 5,61 & 8,08 & & \\
\hline Estonia & 9,96 & 9,03 & 12,13 & 9,75 & \\
\hline Węgry & 7,63 & 5,63 & & & \\
\hline Lotwa & 10,07 & 11,50 & 14,02 & 12,90 & 10,91 \\
\hline Litwa & 6,72 & 10,23 & 15,56 & 13,14 & \\
\hline Polska & 12,14 & 15,42 & 13,58 & 18,50 & \\
\hline Słowacja* & 12,50 & 18,35 & & & \\
& 11,05 & 12,65 & 18,40 & & \\
\hline Słowenia & 7,57 & 7,13 & 6,12 & & \\
\hline
\end{tabular}

* zob. tab. 3.1.

Źródło: jak do tab. 3.1, s. 35.

Oszacowania parametrów równania (3.37) przeprowadzono przy pomocy MNK (Metody Najmniejszych Kwadratów) w poszczególnych przedziałach czasu (oddzielanych przez punkty, w których miały miejsce szczególne zdarzenia w poszczególnych gospodarkach). W tab. 3.1 przedstawiono informacje o podokresach, kiedy dokonano estymacji, zaś w tab. 3.2 przedstawiono wyniki estymacji. $\mathrm{Z}$ analizy danych zawartych $\mathrm{w}$ tab. 3.2 wynika, że stopa bezrobocia NAIRU w takich krajach, jak: Czechy, Słowacja, Litwa (do 2001 r.) i Polska (za wyjątkiem okresu od sierpnia 1996 r. do stycznia 2000 r.) charakteryzowała się $\mathrm{w}$ badanym okresie tendencją rosnącą. Jednocześnie na Węgrzech oraz w Słowenii stopa bezrobocia NAIRU charakteryzowała się w badanym okresie tendencją malejącą. We wszystkich analizowanych krajach poziom bezrobocia równowagi utrzymywał się na stosunkowo wysokim poziomie w stosunku do poziomu bezrobocia faktycznego.

Tabela 3.3. Szacunki bezrobocia NAIRU oraz faktyczna stopa bezrobocia w Czechach w latach 1996-2003 (w \%)

\begin{tabular}{|c|c|c|}
\hline Lata & NAIRU & Faktyczna stopa bezrobocia \\
\hline 1 & 2 & 3 \\
\hline 1996 & 5,9 & 3,52 \\
\hline 1997 & 6,3 & 5,23 \\
\hline 1998 & 6,8 & 7,48 \\
\hline 1999 & 7,3 & 9,37 \\
\hline
\end{tabular}




\begin{tabular}{|c|c|c|}
\hline 1 & 2 & 3 \\
\hline 2000 & 7,5 & 8,78 \\
\hline 2001 & 7,8 & 8,90 \\
\hline 2002 & 7,9 & 9,81 \\
\hline 2003 & 7,9 & 10,30 \\
\hline
\end{tabular}

Źródło: opracowanie własne na podstawie: Hurník 2005, s. 5; Flek, Večernik 2004, s. 10.

Z uwagi na odmienne doświadczenia poszczególnych krajów liczba szoków strukturalnych i tym samym liczba punktów charakterystycznych jest różna. Najdokładniejsze szacunki NAIRU uzyskano w przypadku dwóch punktów charakterystycznych (ang. break points).

Oprócz omówionych powyżej szacunków dla krajów Europy ŚrodkowoWschodniej w literaturze ekonomicznej znaleźć można oszacowania NAIRU dla Czech. W tab. 3.3 przedstawiono oszacowania stopy bezrobocia NAIRU J. Hurníka (2005) dla Czech w latach 1996-2003 oraz dane o faktycznych stopach bezrobocia rejestrowanego w tym samym okresie. Szacunki NAIRU zostały wykonane w oparciu o metody związane z szacowaniem produktu potencjalnego. Z tab. 3.3 wynika, że w latach 1996-2003 występowała w Czechach tendencja wzrostowa NAIRU. W latach 1996-1997 stopa bezrobocia NAIRU w Czechach była wyższa od faktycznej stopy, natomiast w pozostałych latach faktyczna stopa bezrobocia przewyższała NAIRU. Największa różnica między faktyczną stopą bezrobocia NAIRU wystąpiła w 2003 r. i wyniosła 2,4 punktu procentowego.

Podobne wyniki dla Czech uzyskali J. Hurník oraz D. Navrátil (2004). Oszacowania NAIRU dla okresu od I kwartału 1994 do IV kwartału 2004 r. przeprowadzili w oparciu o krótkookresową krzywą Phillipsa. W swoim opracowaniu wykorzystują metodologię estymacji zmiennej w czasie stopy bezrobocia NAIRU (ang. time-varying methodology). Estymacji poddano równanie postaci (zob. Hurník, Navrátil 2004, s. 29):

$$
p_{t}^{\text {core }}=\alpha_{1} E_{t} p_{t+1}^{\text {core }}+\alpha_{2} p_{t-1}^{\text {core }}+\left(1-\alpha_{1}-\alpha_{2}\right) p_{t}^{\text {imp }}+\beta\left(u_{t}-u_{t-1}^{*}\right)+\gamma z_{t-1}+e_{t}
$$

gdzie:

$p^{\text {core }} \quad-$ poziom inflacji bazowej,

$E p_{t+1} \quad$ - oczekiwania inflacyjne,

$p^{i m p} \quad-$ wskaźnik cen dóbr importowanych,

$u_{t} \quad-$ stopa bezrobocia,

$u^{*} \quad-$ stopa bezrobocia $\mathrm{w}$ równowadze,

$z-$ wektor szoków podażowych,

$e_{t} \quad-$ składnik losowy,

$\alpha_{1}, \alpha_{2}, \beta, \gamma$-wielomianowe operatory opóźnień, gdzie $\left(1-\alpha_{1}-\alpha_{2}=0\right)$. 
W opracowaniu wykorzystano wygładzane sezonowo dane kwartalne w stopach bezrobocia oraz wskaźnikach inflacji.

Na podstawie estymacji parametrów równania (3.38) uzyskano następujące oszacowania NAIRU dla Czech (z uwagi na opóźnienia czasowe uzyskano oszacowania NAIRU dla Czech w latach 1995-2003). W latach 1995-1996 stopa bezrobocia NAIRU w Czechach utrzymywała się na stabilnym poziomie. W latach 1996-2003 stopa bezrobocia równowagi wzrosła z 5,5\% do 7,5\%. Podobne wyniki dla Czech uzyskali J. Benes, P. N'Diaye (2004). Według nich stopa bezrobocia NAIRU wzrosła w Czechach z 4\% w 1994 r. do 6,5\% w 2000 r.

\subsection{Podsumowanie}

Z przeprowadzonych rozważań wynikają poniższe wnioski.

Po pierwsze, w literaturze ekonomicznej można znaleźć bardzo wiele metod szacowania bezrobocia równowagi. Wymienia się cztery grupy metod. Należą do nich metody oparte na: przepływach siły roboczej, krzywej Phillipsa, krzywej Beveridge'a oraz szacunkach produkcji potencjalnej. Do najczęściej stosowanych do szacowania bezrobocia równowagi należą dwie pierwsze. Należy podkreślić, że zastosowanie wymienionych metod, z uwagi na odmienne formuły oraz wykorzystywane dane, będzie prowadzić do uzyskania różnych wyników.

Po drugie, estymacja parametrów empirycznej krzywej Phillipsa w celu oszacowania poziomu bezrobocia równowagi wymaga przyjęcia szeregu restrykcyjnych założeń, które mogą być spełnione tylko w przypadku gospodarek stabilnych, a taką w całym badanym okresie (tj. w latach 1995-2011) nie była polska gospodarka.

Po trzecie, oszacowania stóp bezrobocia równowagi w oparciu o metody przepływów są wrażliwe na zmiany koniunktury gospodarczej. Tych wad w szacowaniu zmiennych nieobserwowalnych są pozbawione modele typu VAR, a w szczególności modele wektorowej korekty błędem (VEC). Zaletą modeli typu VEC jest możliwość empirycznej weryfikacji wpływu szoków na bezrobocie równowagi. Ponadto, modele wektorowej korekty błędem umożliwiają analizę m.in. zmiennych niestacjonarnych zintegrowanych w stopniu pierwszym (w przypadku zmiennej zintegrowanej w stopniu pierwszym stacjonarny jest jej pierwszy przyrost).

Po czwarte, z uwagi na to, że modele VAR oparte na średniej ruchomej wymagają arbitralnego przyjęcia pewnych założeń, zastosowanie ich do szacowania bezrobocia równowagi może mieć istotny wpływ na wyniki oszacowań NAIRU.

Po piąte, z analizy oszacowań NAIRU dla nowych krajów UE wynika, że w analizowanym okresie utrzymywał się w nich, tak samo jak w Polsce, wysoki poziom bezrobocia równowagi. Co więcej, we wszystkich badanych krajach stopa bezrobocia równowagi podążała za faktyczną stopą bezrobocia. 


\section{Rozdział 4}

\section{Oszacowania poziomu bezrobocia równowagi w Polsce}

Celem tego rozdziału jest przedstawienie własnych oraz opublikowanych w literaturze ekonomicznej wyników oszacowań stóp bezrobocia NAIRU w Polsce. Własne szacunki NAIRU zostaną przeprowadzone w oparciu o metody przepływów siły roboczej oraz rozszerzoną krzywą Phillipsa. Do przeprowadzenia własnych szacunków NAIRU w oparciu o rozszerzoną krzywą Phillipsa wykorzystano model VAR. W analizach ekonometrycznych zastosowano kwartalne dane statystyczne publikowane przez GUS.

\subsection{Przegląd opublikowanych wyników oszacowań poziomu bezrobocia równowagi w Polsce}

Opublikowane dotychczas w literaturze ekonomicznej oszacowania bezrobocia równowagi $\mathrm{w}$ Polsce zostały przeprowadzone w oparciu o metody: przepływów siły roboczej, oszacowania produkcji potencjalnej oraz krzywą Phillipsa.

Badania empiryczne nad bezrobociem równowagi w Polsce w oparciu o metody oparte na przepływach siły roboczej zostały podjęte przez takich autorów, jak: M. Góra (1998), M. Socha, U. Sztanderska (2000); M. Góra, M. Walewski (2002); E. Kwiatkowski, T. Tokarski, L. Kucharski (2002); M. Bukowski (red.) (2006) oraz L. Kucharski (2006), (2009), (2012). Wszystkie te szacunki uzyskano na podstawie danych indywidualnych z badań aktywności ekonomicznej w Polsce. Z uwagi na odmienne formuły oraz sposób grupowania danych szacunki uzyskane przez poszczególnych autorów różnią się między sobą.

Oszacowania stóp bezrobocia równowagi przeprowadzone przez Górę i Walewskiego (2002) zawiera tab. 4.1. Można z niej wywnioskować, że oszacowania stóp bezrobocia w oparciu o trzy formuły przedstawione w podrozdziale 3.1 różnią się znacznie między sobą. Najwyższe wartości stóp bezrobocia równowagi uzyskano na podstawie formuły (3.25), która nie uwzględnia zmian demograficznych. Wydaje się, że fakt, iż przy wyznaczaniu tej formuły nie uwzględnia się 
zmian demograficznych dyskwalifikuje tę metodę szacowania bezrobocia równowagi. Jak to bowiem wynika $z$ teorii, poziom bezrobocia równowagi zależy od czynników demograficznych. W całym badanym okresie stopa bezrobocia w warunkach stanu stacjonarnego liczona zgodnie $\mathrm{z}$ formułą (3.25) była wyższa od bezrobocia rzeczywistego. Oznaczałoby to więc, że w całym analizowanym okresie nie występowała presja inflacyjna. Wyniki te nie znajdują potwierdzenia w innych badaniach empirycznych.

Należy ponadto zwrócić uwagę, iż oszacowania stóp bezrobocia równowagi w oparciu o formuły (3.9) i (3.15) są do siebie zbliżone (różnica między szacunkami w poszczególnych latach wynosi od 1,1 do 2,2 punktu procentowego. Szacunki bezrobocia równowagi w oparciu o przepływy siły roboczej dają zatem, tak samo jak metody odwołujące się do krzywej Phillipsa, rozbieżne wyniki. Należy więc do tych szacunków podchodzić z pewną dozą ostrożności.

$\mathrm{Z}$ tab. 4.1 wynika ponadto, że w całym analizowanym okresie (za wyjątkiem lat 2000-2001) stopy bezrobocia w warunkach stanu stacjonarnego wyznaczone w oparciu o formuły (3.9) i (3.15) były niższe od rzeczywistej stopy bezrobocia.

Podobne wyniki, do prezentowanych $\mathrm{w}$ tab. 4.1, w latach 2000-2002 przedstawiono w opracowaniu M. Bukowskiego, P. Lewandowskiego, I. Magdy oraz J. Zawistowskiego (stopę bezrobocia równowagi szacowano w oparciu o formułę (3.15)). Z szacunków przedstawionych w tym opracowaniu wynika też, że w latach 2003-2004 stopa bezrobocia równowagi obniżyła się do 18,8\% (zob. Bukowski, Lewandowski, Magda, Zawistowski 2006, s. 27).

W tab. 4.2 przedstawiono szacunki bezrobocia równowagi Sochy i Sztanderskiej (2000), które dotyczą nieco krótszego okresu. Niemniej porównanie danych w tab. 4.1 i 4.2 prowadzi do sformułowania wniosku, że w porównywalnym okresie szacunki stopy bezrobocia w równowadze w oparciu o formułę (3.9) różnią się i to niekiedy znacząco, co wynika stąd, że Socha i Sztanderska szacowali stopy bezrobocia w równowadze w oparciu o kwartalne przepływy siły roboczej. Należy zwrócić uwagę, że szacunki te różnią się także w zależności od zastosowanej formuły. Różnice między stopami bezrobocia w równowadze a rzeczywistą stopą bezrobocia nie są przy tym tak znaczne, jak w przypadku zastosowania formuły (3.25). Wątpliwości budzą jednak szacunki stopy bezrobocia w oparciu o formułę (3.21) z uwagi na to, że dane z badań aktywności ekonomicznej ludności są reprezentatywne dla całej badanej populacji, ale niekoniecznie w przekroju poszczególnych grup ludności. Szacowanie sektorowych stóp bezrobocia w oparciu o przepływy siły roboczej może dawać przypadkowe wyniki.

Z tab. 4.2 wynika, że tak samo jak w przypadku szacunków Góry i Walewskiego, stopy bezrobocia w warunkach stanu stacjonarnego były niższe od rzeczywistej stopy bezrobocia, jednakże różnica między rzeczywistą stopą bezrobocia a średnią stopą bezrobocia $\mathrm{w}$ równowadze wynosiła w badanym okresie tylko 1,6 punktu procentowego. Z tab. 4.1-4.2 wynika, że w Polsce utrzymywał się 
znaczny poziom bezrobocia równowagi w badanym okresie. Szacunki Sochy i Sztanderskiej oraz Góry i Walewskiego wskazują, że bezrobocie równowagi podążało za zmianami faktycznej stopy bezrobocia.

Wyniki badań Góry i Walewskiego różnią się (dla tego samego okresu) w porównaniu do szacunków Sochy i Sztanderskiej (2000)․․ Niestety, ci pierwsi, nie podają sposobu szacowania stóp bezrobocia przedstawionych w tab. 4.1. Prawdopodobnie stopy bezrobocia przedstawione w tab. 4.1 oszacowano w oparciu o roczne stopy przepływów (czyli między ostatnim kwartałem danego roku i ostatnim kwartałem następnego roku). Takie podejście pomija przepływy siły roboczej pomiędzy poszczególnymi kwartałami i w ten sposób otrzymuje się zaniżone szacunki bezrobocia w warunkach stanu stacjonarnego.

Druga grupa opublikowanych oszacowań bezrobocia równowagi dla Polski opiera się na krzywej Phillipsa. Próbę szacunków NAIRU dla Polski podjęli J. Socha i W. Wojciechowski (2004). W swoich analizach wykorzystują dane kwartalne BAEL o stopach bezrobocia, aktywności zawodowej oraz dane GUS o poziomie produkcji, inflacji oraz stóp procentowych. Jako wskaźnik inflacji przyjęto wskaźnik CPI oraz w jednym z modeli inflację bazową. Okres analiz empirycznych obejmuje lata 1993-2002.

Estymacji poddano trzy równania. Pierwsze z nich miało następującą postać (zob. Socha, Wojciechowski 2004, s. 12):

$$
\Delta \pi_{t}=\theta_{1}+\alpha_{2} \mathrm{BAEL}_{t}+\delta_{3} \Delta z_{t}+\Delta_{4} R_{t-1}+\xi_{t}
$$

gdzie:

$\pi \quad-$ logarytm wskaźnik inflacji,

BAEL - stopa bezrobocia BAEL,

$z \quad-$ logarytm wydajności pracy w przemyśle,

$R \quad$ - rzeczywista stopa procentowa.

Estymacja równania (4.1) z włączoną stopą bezrobocia NAIRU oszacowaną za pomocą filtru Kalmana, dokonana w oparciu o dane z lat 1997-2002 dała następujące wyniki (zob. Socha, Wojciechowski 2004, s. 12): w latach 1997-2002 stopa bezrobocia NAIRU kształtowała się w przedziale 12-14\%. Do połowy zaś 1999 r. NAIRU była powyżej rzeczywistej stopy bezrobocia, natomiast od połowy 1999 r. poniżej rzeczywistej stopy bezrobocia.

Uzyskane wyniki przeczą niestety wszystkim szacunkom uzyskanym zarówno w oparciu o analizę przepływów siły roboczej, jak i szacunkom uzyskanym przez G. Kuczyńskiego i K. Strzałę (2006) oraz R. Kelma (2009). Wydaje się, że niezbyt zadowalające rezultaty szacunków równania (4.1) wynikają ze zbyt

\footnotetext{
${ }^{1}$ Wyniki te różnią się również od wyników oszacowań autora niniejszej pracy (zob. Kwiatkowski, Kucharski, Tokarski 2002, s. 335).
} 
krótkiego przedziału czasowego. Estymacja krzywej Phillipsa w tej postaci jest możliwa dla stabilnej gospodarki. Gospodarka Polski w analizowanym okresie znajdowała się jeszcze w fazie transformacji systemowej i w 1997 r. odczuła negatywne efekty kryzysu rosyjskiego. Niestety, tych szoków nie uwzględniono w trakcie specyfikacji modelu. Ponadto estymacja modelu bez badania kointegracji zmiennych może prowadzić do uzyskania korelacji pozornych.

W omawianym opracowaniu oszacowano też parametry równania krzywej poszerzone o oczekiwania adaptacyjne (zob. Socha, Wojciechowski 2004, s. 12):

$$
\Delta \pi=\alpha+\beta(L) f(U)+\gamma Z+\delta(L)\left(\Delta \pi^{e}\right)
$$

gdzie:

$\pi \quad$ - wskaźnik inflacji,

$\pi^{e}$ - oczekiwana inflacja,

$U$ - stopa bezrobocia BAEL,

Z - wstrząsy podażowe oraz strukturalne czynniki wpływające na rynek pracy (udział osób młodych i starych w całkowitej liczbie osób zdolnych do pracy).

Szacunków równania (4.2) nie przedstawiono w opracowaniu z uwagi na jakość uzyskanych wyników.

W omawianym opracowaniu dokonano również estymacji krótkookresowej krzywej Phillipsa postaci²:

$$
\Delta \pi_{t}=\alpha+\beta U_{t}
$$

W długookresowej równowadze $\Delta \pi_{t}=0$, a zatem:

$$
\mathrm{NAIRU}=\frac{\alpha}{\beta}
$$

Estymacja przez autorów równania (4.4) nie dała zadowalających rezultatów dla okresu I kwartał 1993 - IV kwartał 2002. Co prawda skrócenie próby do okresu I kwartał 2000 - IV kwartał 2002 poprawiło znaki oszacowań parametrów modelu (4.4), lecz oszacowania parametrów nie były statystycznie istotne. Wnioskowanie na podstawie takich rezultatów budzi zatem wątpliwości.

Podsumowując, próba szacunków NAIRU podjęta przez Sochę i Wojciechowskiego nie dała zadowalających rezultatów. Było to jednak jedno z pierwszych opracowań w Polsce odwołujących się do koncepcji krzywej Phillipsa.

${ }^{2}$ J. Socha i W. Wojciechowski wykorzystali równanie krótkookresowej krzywej Phillipsa opublikowane w artykule D. Staigera, J. H. Stocka oraz M. Watsona (zob. Staiger, Stock, Watson 1996, s. 19). 

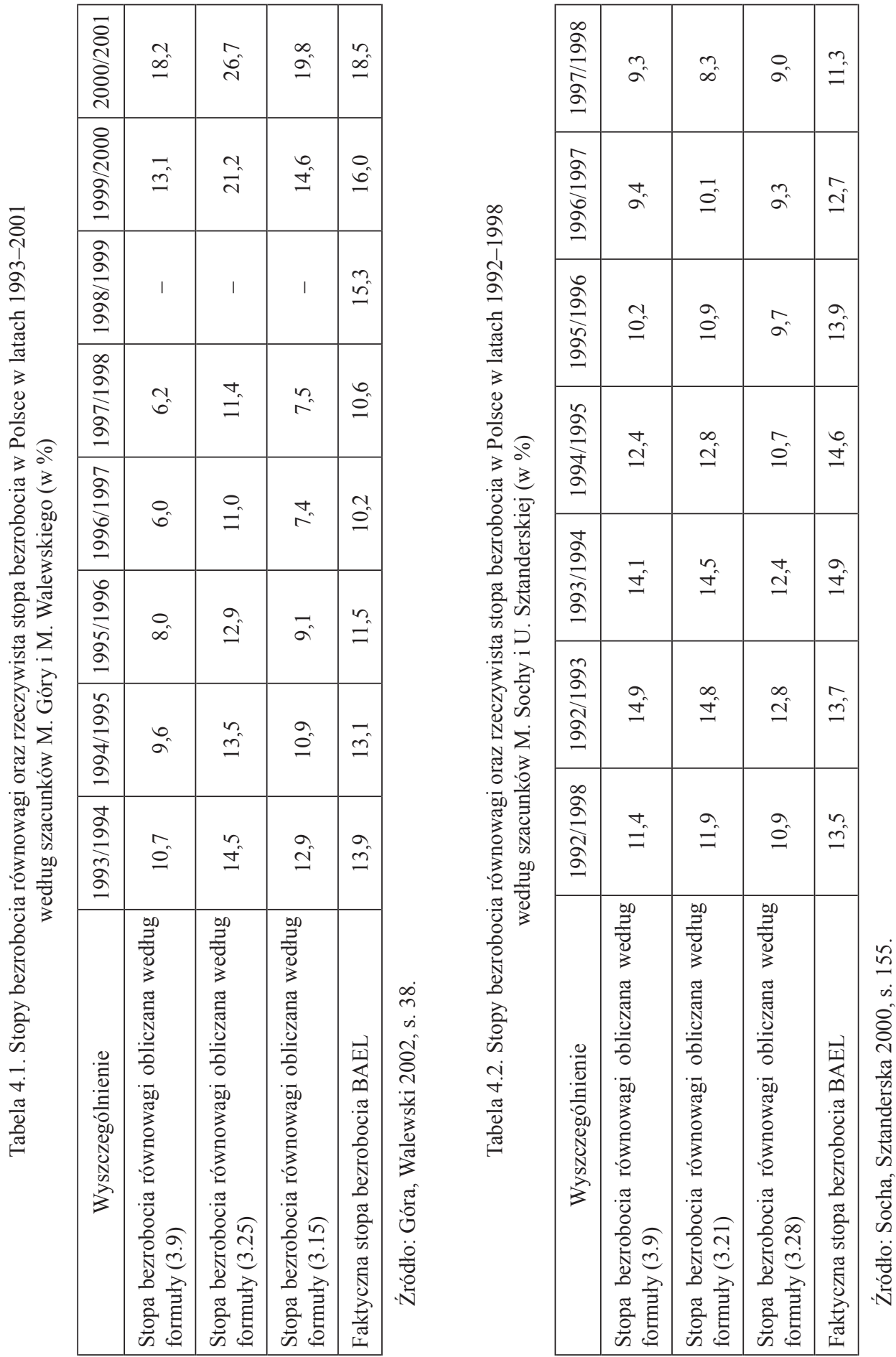
Przyjrzyjmy się obecnie szacunkom NAIRU dla Polski przygotowanym przez G. Kuczyńskiego i K. Strzałę (2006). W omawianym opracowaniu przedstawiono wyniki oszacowań NAIRU w latach 1990-2004. Wykorzystano przy tym dane GUS dotyczące bezrobocia rejestrowanego oraz wskaźniki cen dóbr i usług konsumpcyjnych.

Stopę bezrobocia NAIRU oszacowano zaś w oparciu o model wektorowo-autoregresyjny z zastosowaniem dekompozycji Blancharda i Quaha. W pierwszym etapie konstrukcji modelu VAR przy pomocy testów statystycznych wyznaczono rząd opóźnień modelu. Uzyskane wyniki skłoniły autorów do przyjęcia modelu z opóźnieniem o 7 okresów.

Oszacowano zarazem parametry strukturalne następującego modelu (zob. Kuczyński, Strzała 2006, s. 317):

$$
\begin{aligned}
& \Delta u n r_{t}=\alpha_{1}+\sum_{i=1}^{3} \gamma_{1 i} q_{i}+\sum_{i=1}^{7} \beta_{1 i}^{u n r} \Delta u n r_{t-i}+\sum_{i=1}^{7} \beta_{1 i}^{\text {inf }} \Delta \inf _{t-i}+\varepsilon_{1 t} \\
& \inf _{t}=\alpha_{2}+\sum_{i=1}^{3} \gamma_{2 i} q_{i}+\sum_{i=1}^{7} \beta_{2 i}^{u n r} \Delta u n r_{t-i}+\sum_{i=1}^{7} \beta_{2 i}^{\text {inf }} \Delta \inf _{t-i}+\varepsilon_{2 t}
\end{aligned}
$$

gdzie:

unr - kwartalna rejestrowana stopa bezrobocia,

inf - wskaźnik cen towarów i usług konsumpcyjnych,

$q \quad$ - zero-jedynkowe zmienne sezonowe,

$\alpha, \beta, \gamma-$ parametry strukturalne modelu,

$\varepsilon \quad-$ składniki zakłócające.

W prezentowanym opracowaniu autorzy nie przedstawili jednak danych liczbowych dla całego okresu. Z uwagi na przyjęty rząd opóźnień oszacowano wartość NAIRU dla okresu od IV kwartału 1991 do IV kwartału 2004 r. $\mathrm{Z}$ przedstawionych szacunków wynika, że w badanym okresie wystąpiła tendencja wzrostowa NAIRU. W IV kwartale 1991 r., według szacunków Kuczyńskiego i Strzały (2006), stopa bezrobocia NAIRU w Polsce wyniosła 6,2\%. W ciągu całego badanego okresu stopa bezrobocia NAIRU wzrosła do $12,9 \%$ w IV kwartale 2004 r. Za wyjątkiem 1998 r. stopa bezrobocia NAIRU utrzymywała się poniżej rzeczywistej stopy bezrobocia. Średnia nadwyżka rzeczywistej stopy bezrobocia nad NAIRU wyniosła w analizowanym okresie 5,5 punktu procentowego.

Niewątpliwą zaletą szacunków przedstawionych przez Kuczyńskiego i Strzałę jest to, że dotyczą one tak długiego przedziału czasu. Zastosowana procedura Blancharda-Quaha w celu dekompozycji bezrobocia cyklicznego i bezrobocia równowagi może jednak budzić pewne zastrzeżenia, ponieważ wymaga ona przyjęcia arbitralnie początkowej wartości dowolnego składnika badanej zmiennej. 
Autorzy przyjęli jako początkową wartość bezrobocia cyklicznego średnią wartość stopy bezrobocia wynikającej z przyczyn zakładów pracy.

Wątpliwości może budzić również przyjęcie jako miernika bezrobocia stopy bezrobocia rejestrowanego. Niestety, część rejestrujących się w urzędach pracy to osoby niezainteresowane poszukiwaniem pracy lub pracujące w szarej strefie. Tak samo jak w przypadku estymacji krzywej Phillipsa wydawałoby się tu zasadne przeprowadzenie szacunków w oparciu o inne deflatory.

Z kolei szacunki NAIRU dokonane przez Kelma zostały również przeprowadzone na podstawie modeli typu VAR (zob. Kelm 2009, s. 106-113). W odróżnieniu jednak od szacunków Kuczyńskiego i Strzały, Kelm dokonał estymacji modelu wektorowej korekty błędem (w skrócie VEC).

Szacunki stopy bezrobocia niewywołującej presji inflacyjnej przeprowadzono na podstawie modelu VEC w dwóch wariantach: na podstawie próby miesięcznej obejmującej okres kwiecień 1995 - czerwiec 2006 i na próbie kwartalnej dla okresu I kwartał 1996 - II kwartał 2006. W analizach empirycznych wykorzystano dane o stopach bezrobocia rejestrowanego.

Wybór, która stopa bezrobocia równowagi zostanie oszacowana (NAWRU czy NAIRU), miał z założenia (przyjętego przez autora) charakter empiryczny i został oparty na dwóch kryteriach (zob. Kelm 2009, s. 106):

- szacunek obejmie NAIRU, gdy potwierdzenie empiryczne znajdzie hipoteza o wprost proporcjonalnym przełożeniu zmian wydajności pracy na wzrost płac; w przeciwnym razie zostanie zbadana zmienność NAWRU,

- szacunek NAIRU i/lub NAWRU ma uzasadnienie tylko wtedy, gdy ceny i/lub płace nominalne nie są w systemie VEC zmienną słabo egzogeniczną.

Punktem wyjścia analiz empirycznych było równanie (zob. Kelm 2009, s. 102):

$$
p_{t}=\delta_{1}\left(w_{t}^{p}-l_{t}^{p}\right)+\delta_{2}\left(p^{m}-m+y\right)+\left(1-\delta_{1}-\delta_{2}\right) k^{o}+\mu
$$

gdzie:

$p^{m} \quad$ - złotowy deflator importu,

$w$ - płace,

$l \quad$ - wydajność pracy,

$m-y \quad$ importochłonność produkcji (udział importu w produkcji),

$k^{\circ} \quad-$ pozostałe koszty jednostkowe,

$\delta_{1}, \delta_{2}$ - parametry (z przedziału 0,1$)$.

Szacunki bezrobocia równowagi przeprowadzono na podstawie stóp bezrobocia skorygowanych o bezrobotnych długookresowo. W wyniku estymacji równania (4.6) Kelm zdecydował się na oszacowanie NAWRU ze względu na słabą egzogeniczność cen. W modelu empirycznym uwzględniono następujące zmienne objaśniające: wydajność pracy, deflator importu oraz płace realne. 
W omawianym opracowaniu przedstawiono kwartalne szacunki NAWRU w okresie II kwartał 1996 - II kwartał 2006 oraz tzw. no-shock NAWRU w okresie IV kwartał 1994 - II kwartał 2006. No-shock NAWRU w analizowanym okresie kształtowała się na poziomie 12,9\% (zob. Kelm 2009, s. 125). Wykres 4.1 ukazuje wyniki oszacowań NAWRU zaprezentowane w opracowaniu Kelma w latach 1996-2006. Przedstawiono wyniki tylko z ostatniego kwartału w danym roku.

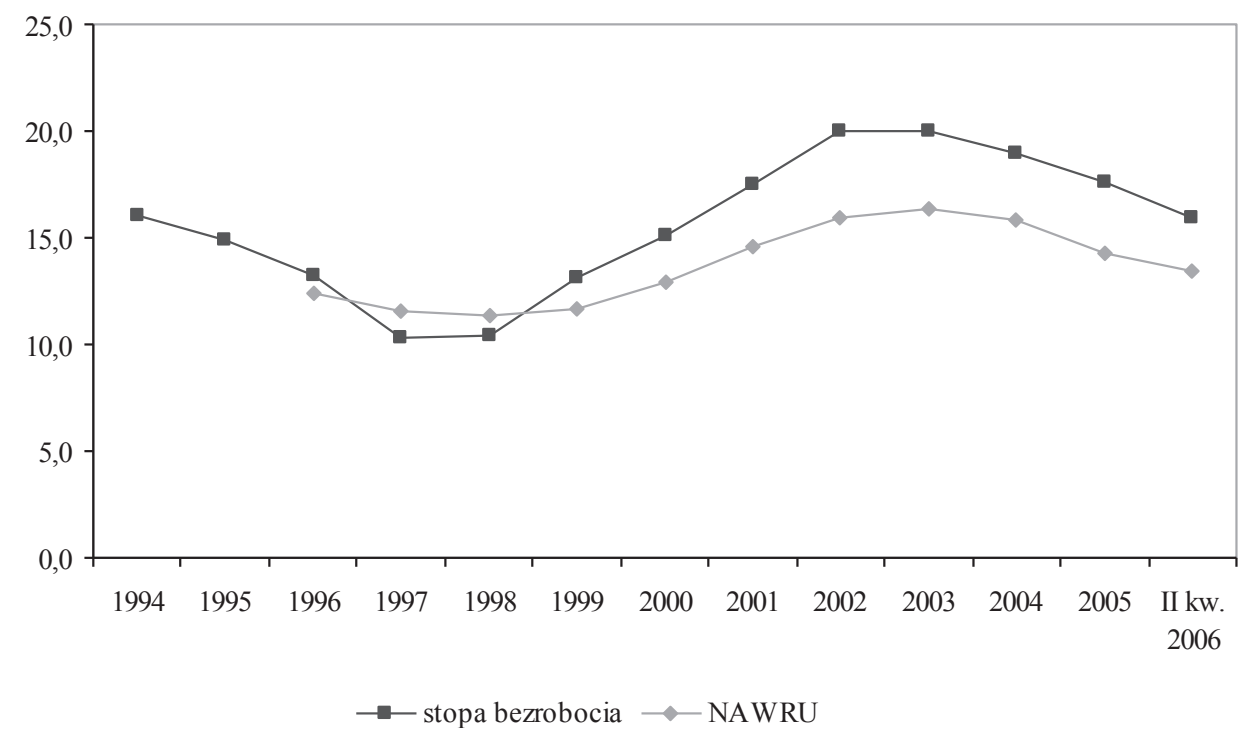

Wykres 4.1. Szacunki NAWRU oraz rzeczywista stopa bezrobocia według BAEL w latach 1994-2006 (w \%)

Źródło: Kelm 2009, s. 117-118; www.stat.gov.pl.

Z wykresu 4.1 wynika, że w 1996 r. oraz w latach 1999-2006 oszacowana przez Kelma stopa bezrobocia NAWRU była niższa od faktycznej stopy bezrobocia. Tylko w latach 1997-1998 NAWRU przewyższała faktyczną stopę bezrobocia. Szacunki Kelma oraz Kuczyńskiego i Strzały nie są porównywalne. Niemniej można powiedzieć, że poziom NAWRU był w analizowanym okresie wyższy od oszacowanych wartości NAIRU przez Kuczyńskiego i Strzałę.

Oprócz szacunków NAWRU Kelm analizuje również wpływ krótkookresowych szoków polegających na zmianie wydajności pracy i płac realnych na poziom krótkookresowej NAWRU. Z przeprowadzonych symulacji wynika, że oddziaływanie szoków krótkookresowych pojawiających się ze strony wydajności pracy powoduje wzrost NAWRU, natomiast wpływ przejściowej zmiany płac realnych jest odwrotny - stopa NAWRU ulega obniżeniu (zob. Kelm 2009, s. 93-127). 
Szacunki NAWRU przedstawione przez Kelma obejmują niemal cały okres transformacji systemowej. Z uwagi na jakość dostępnych danych w opracowaniu pominięto lata 1990-1993. Szacunki NAWRU Kelma spełniają podstawowy warunek akceptowalności hipotez ekonometrycznych, czyli skointegrowania zmiennych w ramach modelu VEC.

Szacunki krótko- i długookresowej NAWRU dla Polski w latach 1995 - I kwartał 2005 w oparciu o teoretyczną koncepcję krzywej płac znaleźć można w pracy K. B. Budnik (2008). Oszacowania endogenicznej stopy bezrobocia równowagi (NAWRU) są wykorzystywane w modelu makroekonomicznym gospodarki polskiej (ECMOD) wykorzystywanym w NBP.

Podstawę szacunków krótkookresowej stopy bezrobocia równowagi stanowiło równanie (zob. Budnik 2008, s. 20):

$$
\begin{aligned}
& \text { nawru }=\left(1-\alpha+\beta_{1}\right)^{-1}\left(\text { tax } \_ \text {wedge }+ \text { price_wedge }+\theta_{1} \text { tot }+ \text { benefits }+\right. \\
& \text { reform } \left.99+\text { const }+(1-\alpha)(l f-k)+\left(\alpha^{-1}-1\right) t f p-\delta\right)
\end{aligned}
$$

gdzie:

price_wedge $=c p i_{-}-p g d p$, tot $=\bar{p}_{-} i m p^{*}-p g d p$,

$\alpha \quad-$ elastyczność PKB względem zatrudnienia,

$\beta_{1} \quad-$ jedna druga elastyczności płac względem bezrobocia,

lf $\quad-$ zasób siły roboczej,

tfp - łączna produktywność czynników wytwórczych,

$k-\quad$ przeciętny poziom zasobu kapitału w danym okresie,

tax_wedge - podatek od płac,

tot $\quad-$ terms of trade,

benefits - zasiłki (dla bezrobotnych i z opieki społecznej).

Długookresową stopę bezrobocia równowagi oszacowano, bazując na równaniu (zob. Budnik 2008, s. 23):

$$
\begin{aligned}
& \text { nawru }{ }^{*}=\beta_{1}^{-1}\left[\text { tax } \_ \text {wedge } e^{*}-\theta_{1} \eta_{1} n f a_{-} g d p-\theta_{1} \eta_{1} \gamma_{2}\left(i_{-} w 3 m-i 3 m_{-} \text {ext }\right)\right. \\
& -\theta_{1} \eta_{1} \gamma_{3} d 04 q 2+\text { benefits }+ \text { reform } 99+\text { const }{ }^{*} \\
& \left.+ \text { dummy }+\frac{1-\alpha}{\alpha}(\text { rucc }-\ln (1-\alpha))-\delta\right]
\end{aligned}
$$

gdzie:

$n f a \_g d p \quad-$ stosunek zagranicznych aktywów netto do PKB,

$i_{-} w 3 m-$ realna stopa oprocentowania WIBOR3M,

$\bar{i} 3 m_{-}$ext $\quad$ realna stopa oprocentowania trzymiesięcznych kredytów za granicą,

rucc - koszt kapitału w ujęciu realnym,

d04q2, dummy - zmienne sztuczne. 
Z analizy wyników oszacowań równania (4.7) można wywnioskować, że w latach 1995-1999 wystąpiła tendencja spadkowa krótkookresowej stopy bezrobocia NAWRU. W 1995 r. NAWRU krótkookresowa utrzymywała się na poziomie ponad 16\%. W 1999 r. krótkookresowa stopa bezrobocia NAWRU osiągnęła poziom 12\%. W latach 1999-2003 krótkookresowa stopa bezrobocia NAWRU charakteryzowała się (tak samo jak faktyczna stopa bezrobocia) tendencją wzrostową. W 2003 r. krótkookresowa NAWRU osiągnęła znowu poziom ponad 16\%, natomiast $\mathrm{w}$ następnych latach oscylowała w przedziale 15-16\%. Oszacowania krótkookresowej NAWRU Budnik są zbliżone do oszacowań Kelma (2009).

Z analizy oszacowań równania (4.8) wynika, że w latach 1995-2000 steadysteate NAWRU charakteryzowała się tendencją rosnącą. Od 2001 do 2005 r. wraz ze złagodzeniem polityki pieniężnej długookresowa NAWRU charakteryzowała się tendencją malejącą.

Niewątpliwą zaletą oszacowań stopy bezrobocia NAWRU przedstawionych w opracowaniu Budnik jest fakt, iż uwzględnia ona w swoich analizach szereg zmiennych instytucjonalnych mających wpływ na szeroko pojęte bezrobocie równowagi. Dlatego też oszacowania NAWRU w tym opracowaniu są bardzo przydatne dla prowadzenia polityki makroekonomicznej, a w szczególności polityki pieniężnej.

Szacunki NAIRU/NAWRU dla Polski w oparciu o metody oparte na szacunkach produkcji potencjalnej można znaleźć w analizach P. Krajewskiego (2006) oraz M. Gradzewicza i M. Kolasy (2004). Celem każdego z tych opracowań było oszacowanie luki popytowej, a nie NAWRU. Szacunki NAIRU miały posłużyć do wyznaczenia nakładu pracy.

W badaniu Krajewskiego naturalną stopę bezrobocia (NAIRU) wyznaczono na podstawie szeregów czasowych skorygowanych o wahania sezonowe kwartalnych stóp bezrobocia w okresie I kwartał 1995 - IV kwartał 2003 (zob. Krajewski 2006, s. 104-105). Naturalną stopę bezrobocia wyznaczono, bazując na filtrze Hodricka-Prescotta. Filtr ten wygładza szereg czasowy jednak, w odróżnieniu od trendu liniowego, uzyskany trend nie ma jednakowego nachylenia w całym okresie. Przyjęto parametr wygładzający w wysokości 1600. Z oszacowań przedstawionych w omawianym opracowaniu wynika, że NAIRU oszacowana tą metodą podążała za faktyczną stopą bezrobocia.

Wydaje się, że wyniki oszacowań na podstawie metod filtracyjnych są niezbyt wiarygodne w szacowaniu NAIRU czy NAWRU. A zatem wyniki uzyskane $\mathrm{z}$ wykorzystaniem tych metod są też mało przydatne dla prowadzenia polityki pieniężnej.

Szacunki NAWRU Gradzewicza i Kolasy zostały przeprowadzone w oparciu o metodę Elmeskova (zob. Gradzewicz, Kolasa 2004, s. 17-18). Wadą tej metody jest to, że uzyskane NAWRU krótkookresowe zmienia się wraz ze zmianami faktycznej stopy bezrobocia. Wyjaśnieniem takiego zachowania się NAWRU jest to, że inflacja płac zmienia się nie tylko pod wpływem poziomu, lecz także zmian 
bezrobocia. Problem ten redukuje się poprzez wygładzenie uzyskanego szeregu filtrem Hodricka-Prescotta. Stosowanie tej metody wymaga doboru parametru wygładzającego (przyjęto, tak jak u Krajewskiego, parametr wygładzający 1600, stosowany zazwyczaj w przypadku danych kwartalnych) oraz skutkuje obciążeniem wyników na początku i końcu próby.

Szacunki NAWRU przeprowadzono na podstawie danych kwartalnych stóp bezrobocia BAEL i płac w latach 1995-2002. Aby złagodzić problem obciążenia wyników na początku próby, do analizy włączono lata 1992-1994. Natomiast kwestię obciążenia wyników na końcu próby rozwiązano przyjmując, że średni poziom NAWRU w 2002 r. wynosił 16\%.

Autorzy nie przedstawili dokładnych danych liczbowych. Z wykresu zamieszczonego w artykule wynika, że w latach 1995-1998 NAWRU charakteryzowała się tendencją malejącą, natomiast w latach 1999-2002 podążała za faktyczną stopą bezrobocia. W latach 1995-1998, za wyjątkiem niektórych kwartałów, NAWRU utrzymywała się powyżej faktycznej stopy bezrobocia. Od 1999 r. stopa bezrobocia NAWRU utrzymywała się do końca okresu poniżej faktycznej stopy bezrobocia. Zastosowana metoda szacowania NAWRU budzi szereg wątpliwości natury ekonometrycznej. Wobec przyjętej liczby założeń upraszczających uzyskane przez Gradzewicza i Kolasę wyniki oszacowań są raczej mało przydatne w prowadzeniu polityki pieniężnej.

Oszacowania stóp bezrobocia równowagi dla Polski przygotowane przez K. Leszkiewicz-Kędzior i W. Welfe (2013) zostały przeprowadzone na podstawie wielu metod. Analizy obejmują lata 1991-2008. Autorzy podjęli próbę oszacowania stóp NAIRU i NAWRU dla Polski, wykorzystując różne metody stosowane w literaturze światowej. W pierwszym etapie oszacowano stopy NAWRU i NAIRU według procedur uproszczonych opartych na klasycznej i zmodyfikowanej krzywej Phillipsa. W następnym etapie zostały wykorzystane bardziej złożone metody szacowania stóp bezrobocia równowagi. Przeprowadzone zostały również oszacowania poziomu bezrobocia równowagi w oparciu o zredukowaną krzywą Phillipsa (zob. Leszkiewicz-Kędzior, Welfe 2013, s. 93-108).

Uzyskane wyniki analiz autorzy przedstawili jedynie w postaci wykresów, a zatem nie w pełni można analizować konkretne dane. Wyniki oszacowań stóp bezrobocia równowagi (uzyskane w oparciu o wszystkie metody) przez Leszkiewicz-Kędzior i Welfe są do siebie zbliżone. Nie różnią się one znacząco od poziomu faktycznych stóp bezrobocia rejestrowanego. Niezależnie od zastosowanej metody oszacowane stopy bezrobocia równowagi zmieniają się w tym samym kierunku co faktyczna stopa bezrobocia.

Niewątpliwą zaletą analiz przeprowadzonych przez Leszkiewicz-Kędzior i Welfego jest szerokie spektrum metod wykorzystanych w opracowaniu oraz bardzo długi okres analizy. Uzyskane wyniki mogą być „obciążone” w początkowych latach z uwagi na to, że był to początkowy okres transformacji polskiej gospodarki. 


\subsection{Wlasne wyniki oszacowań stóp bezrobocia NAIRU w Polsce w oparciu o metody przepływów siły roboczej w latach 1993-20093}

W tym podrozdziale prezentowane są oszacowania bezrobocia równowagi (NAIRU) przeprowadzone przez autora niniejszej pracy w oparciu o metody przepływów siły roboczej. Wykorzystano tutaj formuly (3.9) i (3.15) przedstawione w podrozdziale 3.1. Formuła (3.15) zawiera wszystkie stopy przepływów, natomiast formuła (3.9) obejmuje oprócz większości stóp przepływów również tzw. składnik demograficzny oraz stopę przyrostu zasobu siły roboczej.

Rozważmy najpierw relacje między faktyczną stopą bezrobocia a stopą bezrobocia równowagi w latach 1993-2009 (zob. wykres 4.2). Stopy bezrobocia równowagi obliczono tu jako średnie arytmetyczne kwartalnych stóp bezrobocia równowagi w okresie luty danego roku luty następnego roku do $1999 \mathrm{r}$. W latach 2000-2009 roczne stopy bezrobocia równowagi obliczono natomiast jako średnie kwartalne stóp bezrobocia równowagi w okresie I kwartał danego roku - I kwartał następnego roku. Faktyczne stopy bezrobocia w poszczególnych latach to średnie kwartalne stóp bezrobocia z badań aktywności ekonomicznej ludności w latach 1993-2009. Stopę bezrobocia równowagi (ur) oszacowano w oparciu o formułę (3.9), zaś stopę bezrobocia równowagi (us) - na podstawie formuły (3.15).

Wykres 4.2 przedstawia dane o stopach bezrobocia faktycznego i stopach bezrobocia równowagi, natomiast na wykresie 4.3 zaprezentowano dane o relacjach między stopami bezrobocia faktycznego i bezrobocia równowagi.

$\mathrm{Z}$ wykresu 4.2 wynika po pierwsze, że w całym analizowanym okresie obie stopy bezrobocia równowagi zmieniały się w tym samym kierunku, co faktyczna stopa bezrobocia. W latach 1993-1998 oraz w latach 2002-2008 spadkowi bezrobocia ogółem towarzyszył spadek obu stóp bezrobocia równowagi, natomiast w latach 1999-2003 oraz w 2009 r. wraz ze wzrostem bezrobocia ogółem wzrastało również bezrobocie równowagi. Należy jednak podkreślić, że spadek stóp bezrobocia ogółem i bezrobocia równowagi w 2002 r. był nieznaczny. Może to wskazywać na występowanie efektu histerezy. Hipoteza ta wymaga jednak bliższej weryfikacji. Po drugie, prawie w całym analizowanym okresie (za wyjątkiem 2001 r.) obie oszacowane stopy bezrobocia równowagi były niższe od faktycznej stopy bezrobocia, czyli utrzymywał się pewien poziom bezrobocia koniunkturalnego. Po trzecie, spadek obu oszacowanych stóp bezrobocia równowagi w latach 1993-1998 oraz 2002-2008 wskazuje na redukcję bezrobocia strukturalnego w tym czasie. Natomiast wzrostowa tendencja obu stóp bezrobocia równowagi w latach 1999-2003 oraz w 2009 r. wskazuje na wzrost niedopasowań strukturalnych w tych latach.

\footnotetext{
${ }^{3}$ Częściowe wyniki prezentowane w tym podrozdziale można znaleźć w: Kwiatkowski, Kucharski, Tokarski (2002); Kwiatkowski, Kucharski (2009); Kucharski (2006), (2009), (2012).
} 


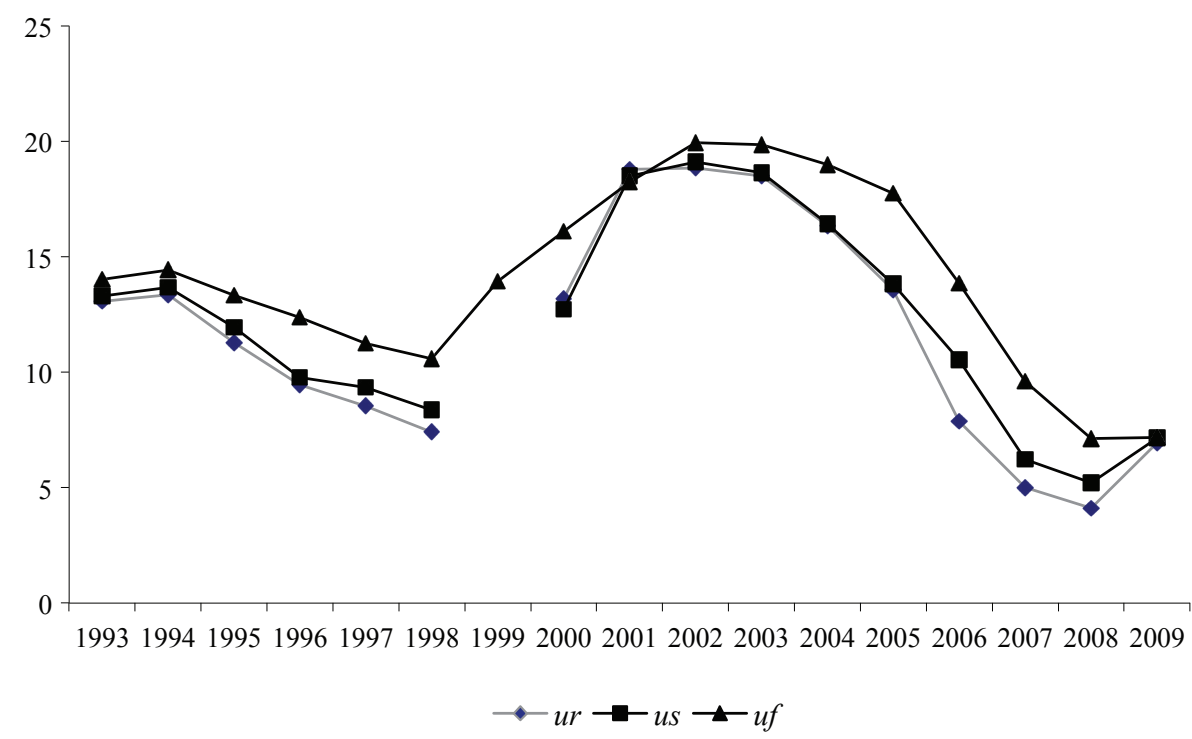

Wykres 4.2. Faktyczna stopa bezrobocia (uf), stopa bezrobocia równowagi (ur) oszacowana w oparciu o formułę (3.9) oraz stopa bezrobocia równowagi (us) oszacowana w oparciu o formułę (3.15) w Polsce w latach 1993-2009 (w \%)

Źródło: dane jednostkowe BAEL z lat 1993-2009 oraz GUS, Aktywność Ekonomiczna Ludności Polski, różne wydania z lat 1995-2007; obliczenia własne.

Z wykresu 4.3 wynika, że w całym analizowanym okresie utrzymywał się w Polsce wysoki udział bezrobocia równowagi w bezrobociu ogółem. Najniższy udział bezrobocia równowagi w bezrobociu ogółem wystąpił w 2007 r. Relacja stopy bezrobocia równowagi (ur) oszacowanej na podstawie wzoru (3.9) do stopy bezrobocia faktycznego wyniosła $\mathrm{w}$ tym roku 52,1, zaś relacja stopy bezrobocia równowagi (us) oszacowanej w oparciu o wzór (3.15) do faktycznej stopy bezrobocia wyniosła 64,7. Najwyższy udział bezrobocia równowagi w bezrobociu ogółem wystąpił w $2001 \mathrm{r}$. W $2001 \mathrm{r}$. faktyczna stopa bezrobocia (uf) była równa stopie bezrobocia równowagi $(u s)$, natomiast relacja stopy bezrobocia równowagi (ur) do faktycznej stopy bezrobocia wyniosła 101,6. Z wykresu 4.3 można również wywnioskować, że udział bezrobocia równowagi w bezrobociu ogółem był skorelowany ze zmianami tempa wzrostu gospodarczego. W latach 1993-1998 (za wyjątkiem 1997 r.) oraz w latach 2002-2008 wraz ze spadkiem bezrobocia faktycznego oraz bezrobocia równowagi malał też udział bezrobocia równowagi w bezrobociu ogółem. Natomiast w latach 1999-2001 wraz z silnym wzrostem bezrobocia ogółem i bezrobocia równowagi rósł również udział bezrobocia równowagi w bezrobociu ogółem. Należy jednak podkreślić, że spadek udziału bezrobocia równowagi w bezrobociu ogółem w latach 2005-2008 był zdecydowanie silniejszy niż w latach 1993-1998. 


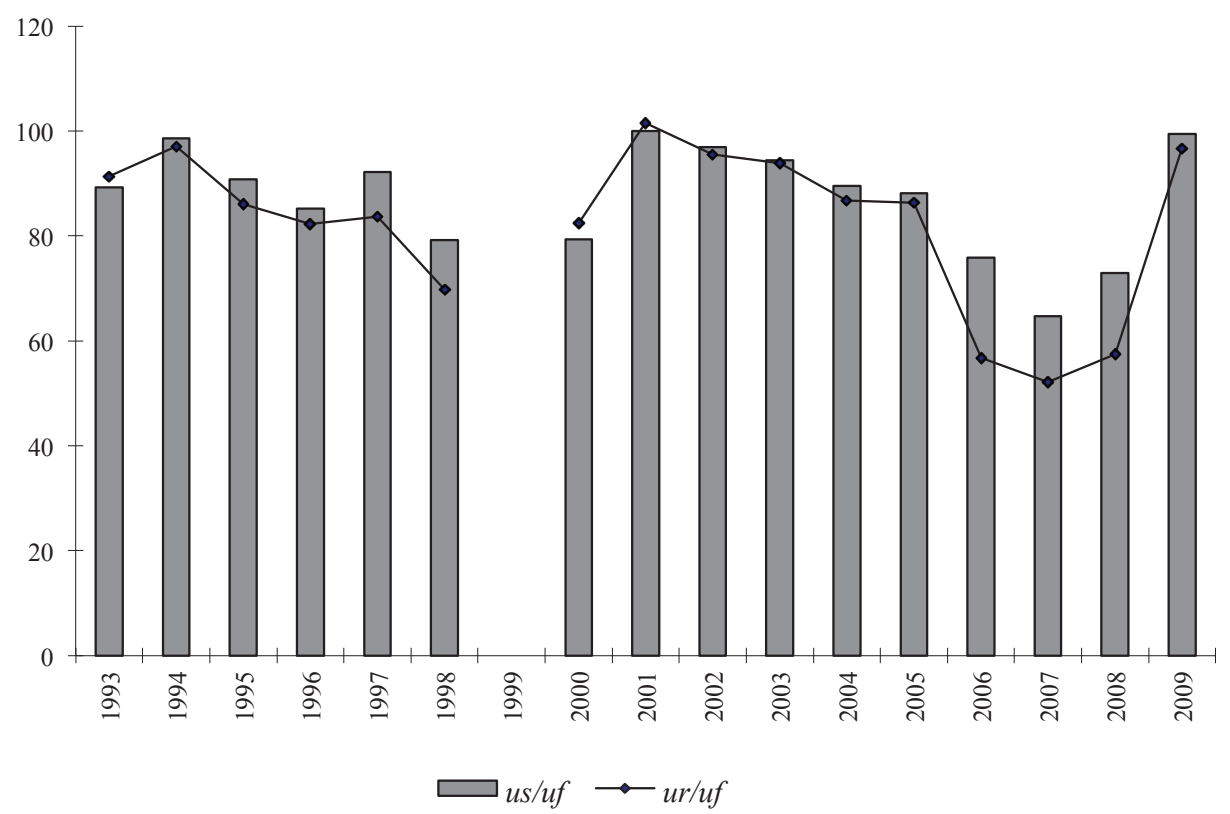

Wykres 4.3. Relacja między stopami bezrobocia równowagi (ur) oraz (us) a stopą bezrobocia faktycznego (uf) w Polsce w latach 1993-2009

Źródło: jak do wykresu 4.2; obliczenia własne.

Bazując na metodach przepływów, można szacować stopy bezrobocia w warunkach stanu stacjonarnego w poszczególnych grupach siły roboczej. Szacunki takie zostały przygotowane w Polsce np. przez Kucharskiego (2002) oraz Sochę i Sztanderską (2000). Do tych szacunków należy jednak podchodzić z dużą ostrożnością. Badania aktywności ekonomicznej ludności są reprezentatywne dla całej Polski, lecz nie są one reprezentatywne we wszystkich przekrojach społeczno-demograficznych.

\subsection{Wlasne wyniki oszacowań stóp bezrobocia NAIRU w oparciu o rozszerzoną krzywą Phillipsa}

\subsubsection{Model VAR}

Większość zjawisk ekonomicznych w gospodarce ma charakter łącznie współzależny, dlatego do ich opisu najczęściej wykorzystuje się modele łącznie współzależne. Na przełomie lat 70. i 80 . XX w. wykazane zostały liczne wady modeli tego typu (zob. Charemza, Deadman 1997, s. 151-152), m.in. problem 
identyfikacji zmiennych. Próbowano go unikać poprzez dodawanie zmiennych niemających uzasadnienia na gruncie ekonomii. W modelach tego typu wykluczano występowanie sprzężenia zwrotnego (współliniowości zmiennych). Podział zmiennych na endo- $\mathrm{i}$ egzogeniczne $\mathrm{w}$ tego typu modelach ma w zasadzie charakter arbitralny.

Te wady zostały wyeliminowane w modelach typu VAR (wektorowej autoregresji). W modelach tego typu zmiennymi objaśniającymi są opóźnienia wszystkich zmiennych występujących w modelu.

W modelu ekonometrycznym służącym do oszacowania stóp bezrobocia NAIRU w Polsce w latach 1995-2011 w oparciu o rozszerzoną krzywą Phillipsa zdecydowano się na wykorzystanie następujących zmiennych ekonomicznych: płace realne, wydajność pracy, CPI, stopa bezrobocia oraz wskaźnik cen transakcyjnych importu. Dla $p=5$ zmiennych wykorzystywanych w naszym modelu ${ }^{4}$ i $k$ opóźnień model VAR możemy zapisać w następującej postaci (zob. Welfe 2003, s. 355):

$$
\mathbf{X}_{\mathbf{t}}=\Pi_{1} \mathbf{X}_{t-1}+\Pi_{2} \mathbf{X}_{t-2}+\Pi_{3} \mathbf{X}_{t-3}+\ldots+\Pi_{k} \mathbf{X}_{t-k}+\sum_{t} \quad t=k+1, \ldots, T
$$

gdzie:

$\boldsymbol{X}_{t}$ - to pięcioelementowy wektor zmiennych wykorzystywanych w modelu (czyli: $W R, D C P I, Y, U, P M$ ),

$\boldsymbol{X}_{t-i}$ - to pięcioelementowy wektor obserwacji wszystkich zmiennych wykorzystanych w modelu opóźnionych o $t-i$,

$\Pi_{i}$ - macierz parametrów o wymiarach 5 na 5, nazywana macierzą mnożników całkowitych,

$\Sigma_{t}-$ macierz składników losowych $(\mathrm{N}(0, \Omega))$.

W modelach VAR nie występuje podział na zmienne endo- i egzogeniczne. Ponadto, modele tego typu nie są oparte na teoriach ekonomicznych. Punktem wyjścia w modelach VAR jest sformułowanie niepoddanego żadnym restrykcjom modelu wektorowej autoregresji. W naszym przypadku model składa się z pięciu równań, w których po lewej stronie znajdowałyby się poszczególne zmienne, a po prawej wszystkie zmienne opóźnione o $t-i$ (gdzie $i$ - rząd opóźnień). Wszystkie równania zawierają te same regresory. Przyjęty rząd opóźnień jest wystarczający, aby składnik losowy był białym szumem (zob. Welfe 2003, s. 356).

${ }^{4} \mathrm{~W}$ modelu ekonometrycznym płace realne oznaczono symbolem WR, wydajność pracy - Y, przyrost wskaźnika cen dóbr konsumpcyjnych - DCPI, stopę bezrobocia - U, zaś wskaźnik cen transakcyjnych importu (deflator importu) - PM. 
Równanie (4.9) można przekształcić do modelu wektorowej korekty błędem (VEC) (zob. Johansen 1995, s. 89; Welfe 2003, s. 356):

$$
\Delta \mathbf{X}_{\mathbf{t}}=\Pi \mathbf{X}_{t-1}+\sum_{i=1}^{k-1} \Gamma_{i} \Delta \mathbf{X}_{t-1}+\Sigma_{t}
$$

gdzie:

$\Pi=\left(\sum_{i=1}^{k} \Pi_{i}-\mathbf{I}\right)=-\Gamma_{k}$ oraz $\boldsymbol{\Pi}=\boldsymbol{\alpha} \boldsymbol{\beta}^{\mathrm{T}}$

$\Gamma_{\mathbf{i}}=-\sum_{j=i+1}^{k} \Pi_{j}$

$\boldsymbol{\beta}-$ macierz $\mathrm{r}$ wektorów kointegrujących (w naszym modelu $r=5$ ).

$\Gamma_{t}-$ macierz efektów krótkookresowych.

Model (4.10) można poszerzyć o zmienne deterministyczne (np. trend). Po ich uwzględnieniu równanie (4.10) przyjmie postać:

$$
\Delta \mathbf{X}_{\mathbf{t}}=\alpha \beta^{\mathrm{T}} \mathbf{X}_{t-1}+\sum_{i=1}^{k-1} \Gamma_{i} \Delta \mathbf{X}_{t-1}+\Psi \mathbf{D}_{t}+\Sigma_{t}
$$

gdzie:

$\mathbf{D}_{t}$ - macierz zmiennych deterministycznych,

$\boldsymbol{\Psi}$ - macierz parametrów związanych ze zmiennymi deterministycznymi.

Równanie (4.11) stanowi podstawę dalszych analiz empirycznych. Oszacowania parametrów równania (4.11) otrzymano przy pomocy metody największej wiarygodności (MNW).

\subsubsection{Wykorzystane dane statystyczne}

Dla potrzeb analizy w tym podrozdziale zgromadzono następujący zestaw kwartalnych danych statystycznych:

- przeciętne wynagrodzenie w gospodarce narodowej w okresie I kwartał 1995 - II kwartał 2011 (w zl),

- wskaźnik cen dóbr konsumpcyjnych CPI (I kwartał 1995 r. = 100) w okresie I kwartał 1995 - II kwartał 2011,

- wydajność pracy w ujęciu realnym $(2000$ r. = 100) w okresie I kwartał 1995 - II kwartał 2011 (w mln zł),

- stopa bezrobocia według BAEL w okresie I kwartał 1995 - II kwartał 2011 r.,

- deflator kwartalny PKB w okresie I kwartał 1995 - II kwartał 2011 (2000 r. $=100$ ),

- wskaźnik cen transakcyjnych importu (rok $2000=100)$ w okresie I kwartał 1995 - II kwartał 2011.

Wydajność pracy zdefiniowano jako stosunek PKB w cenach stałych z $2000 \mathrm{r}$. do liczby pracujących według BAEL. Większość wyjściowych zmiennych 
makroekonomicznych wykorzystanych $\mathrm{w}$ analizach jest zintegrowana $\mathrm{w}$ stopniu pierwszym.

Wydajność pracy w ujęciu realnym, wskaźnik cen transakcyjnych importu oraz stopa bezrobocia są typu I(1). Natomiast przeciętne wynagrodzenia oraz wskaźnik CPI są zmiennymi zintegrowanymi drugiego stopnia (czyli typu I(2)). Dlatego też w analizach ekonometrycznych wykorzystane zostaną płace realne, które są zintegrowane w stopniu 1.

Przeciętne wynagrodzenie w ujęciu realnym zdefiniowano jako stosunek przeciętnego wynagrodzenia w gospodarce narodowej do CPI (I kwartał $1995=100)$. Ponieważ pierwszy przyrost wskaźnika CPI jest zintegrowany w stopniu 1, zamiast wskaźnika CPI wykorzystywany będzie pierwszy przyrost wskaźnika CPI.

Analizy ekonometryczne w tym rozdziale zostały przeprowadzone przy wykorzystaniu danych kwartalnych z okresu I kwartał 1995 - II kwartał 2011. W analizach ekonometrycznych wykorzystano następujący zestaw kwartalnych danych statystycznych:

- wydajność pracy w cenach stałych z 2000 r. (zdefiniowana jako stosunek PKB w cenach stałych z 2000 r. do liczby pracujących według BAEL),

- przeciętne wynagrodzenie w ujęciu realnym (I kwartał 1995 r. = 100) (w zł),

- przyrost CPI,

- stopa bezrobocia według BAEL (w \%),

- wskaźnik cen transakcyjnych importu (rok $2000=100)$.
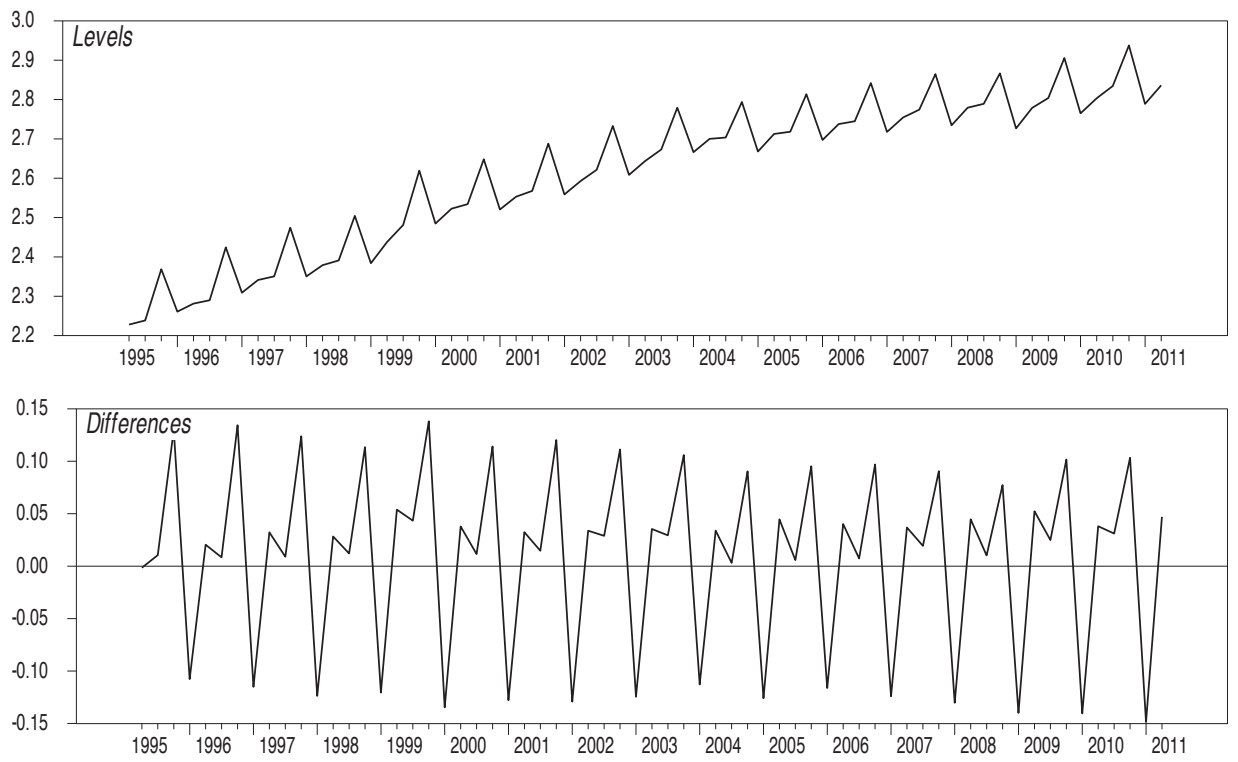

Wykres 4.4a. Wydajność pracy (w cenach stałych z 2000 r.) oraz jej pierwsze przyrosty, I kwartał 1995 - II kwartał 2011 r. (w mln zł)

Źródło: www.stat.gov.pl; obliczenia własne. 

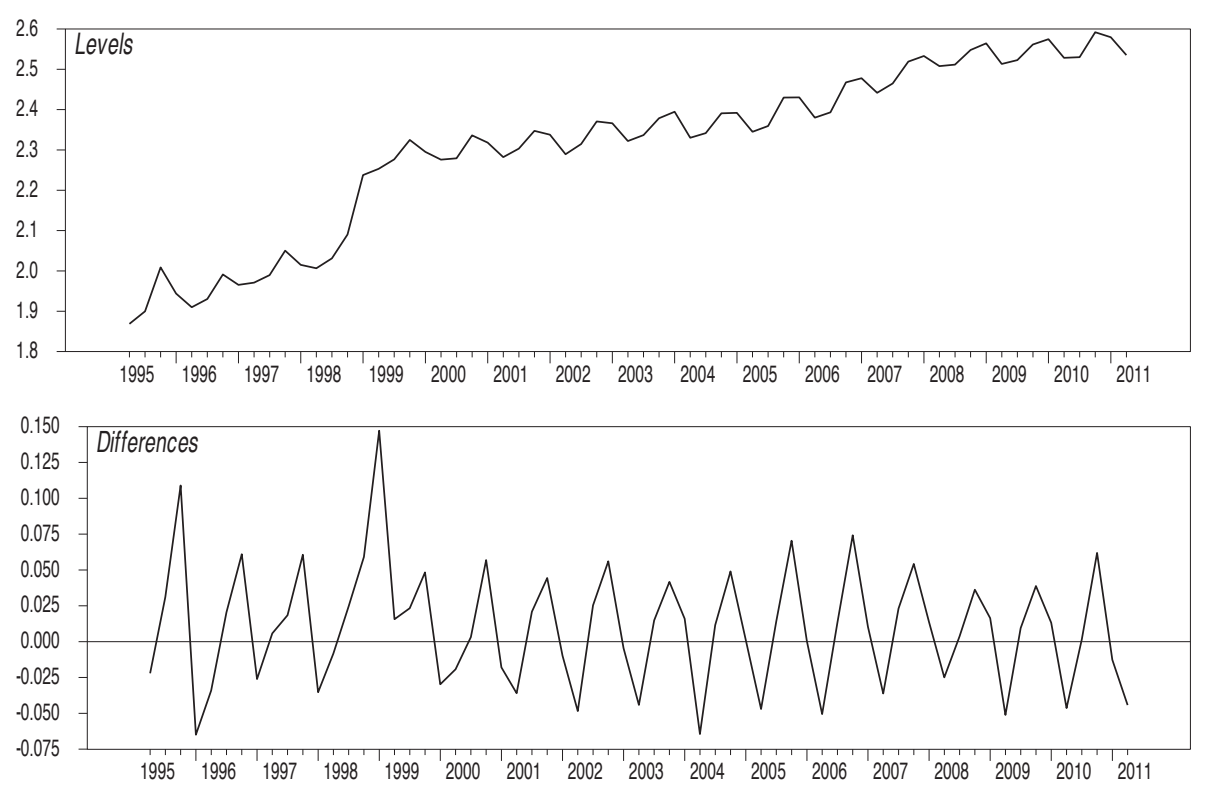

Wykres 4.4b. Przeciętne wynagrodzenie w ujęciu realnym oraz jego pierwsze przyrosty, I kwartał 1995 - II kwartał 2011 r. (w zł)

Źródło: Komunikaty Prezesa GUS: www.stat.gov.pl; Monitory Polskie z lat 1995-2011; obliczenia własne.

Na wykresach 4.4a-4.4.e przedstawiono tendencje zmian poszczególnych zmiennych oraz ich przyrostów w czasie ${ }^{5}$. Wynika z nich, że wszystkie zmienne są zintegrowane w stopniu 1, ponieważ ich pierwsze przyrosty są stacjonarnymi szeregami czasowymi. W poszczególnych szeregach czasowych występują pewne nietypowe obserwacje.

W całym analizowanym okresie wystąpiła dosyć silna tendencja wzrostowa (z pewnymi wahaniami sezonowymi) wydajności pracy. Rosły również przeciętne wynagrodzenia w ujęciu realnym. Przyrost wskaźnika CPI charakteryzował się dużą zmiennością. Widoczny jest silny spadek inflacji CPI. Stopy bezrobocia w badanym okresie były silnie skorelowane ze zmianami koniunktury gospodarczej. Wskaźnik cen transakcyjnych importu wykazywał także tendencję wzrostową.

${ }^{5}$ Ponieważ w analizach ekonometrycznych posługujemy się równaniami logarytmiczno-liniowymi, na wykresach 4.4a-4.4e przedstawiono zlogarytmowane wartości zmiennych (za wyjątkiem stopy bezrobocia). 

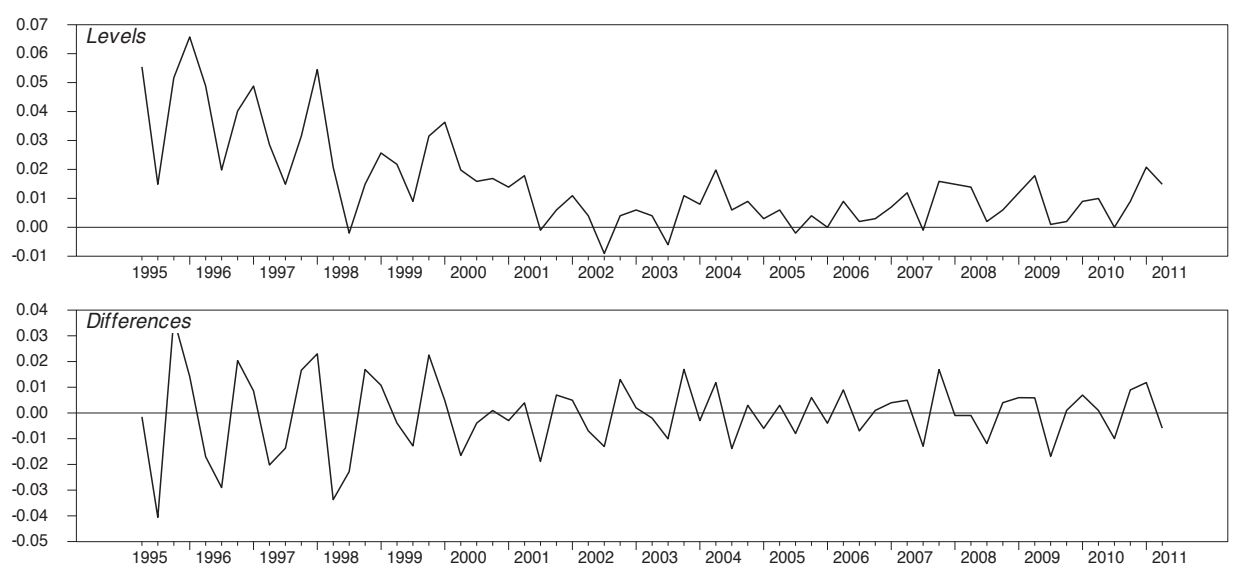

Wykres 4.4c. Przyrost CPI oraz jego pierwsze przyrosty, I kwartał 1995 - II kwartał 2011 r. Źródło: jak do wykresu 4.4a.
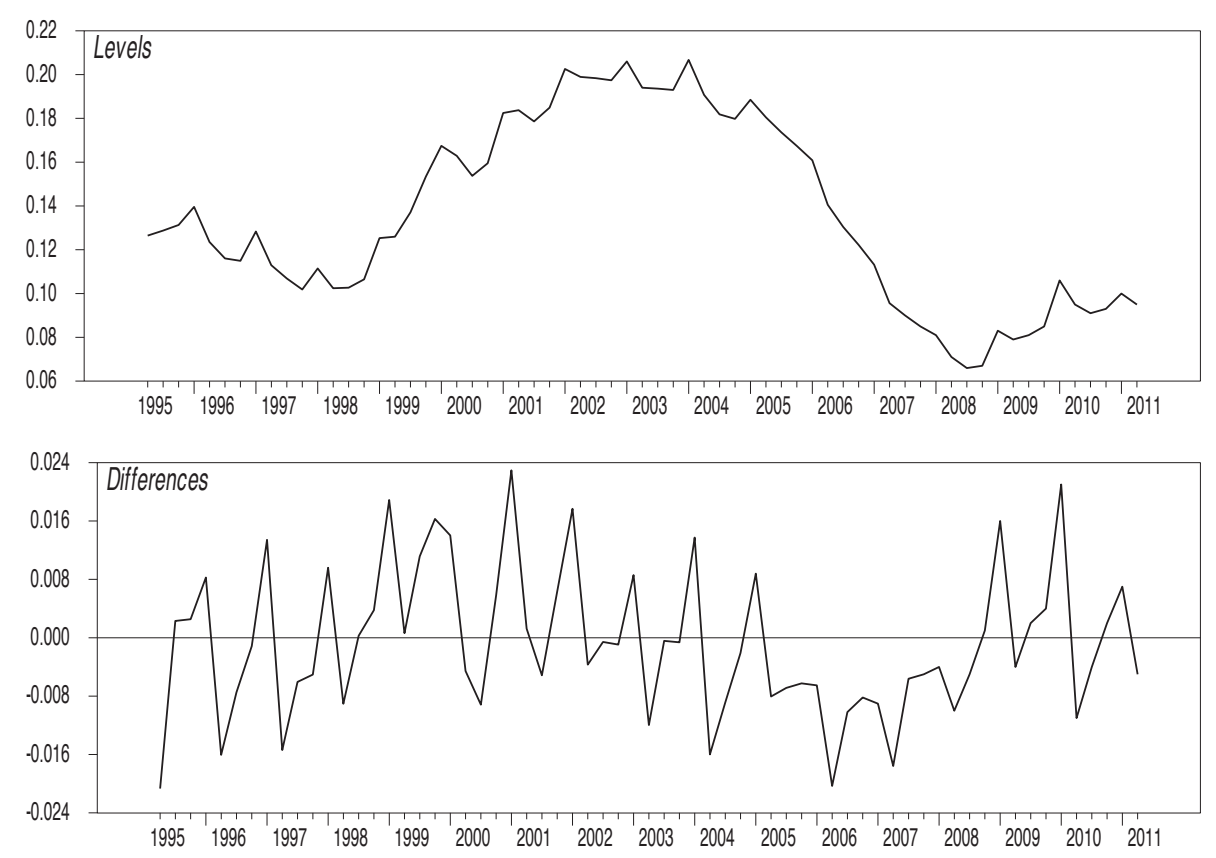

Wykres 4.4d. Stopy bezrobocia według BAEL oraz ich pierwsze przyrosty, I kwartał 1995 - II kwartał $2011 \mathrm{r}$.

Źródło: GUS, Aktywność ekonomiczna ludności Polski, różne wydania z lat 1995-2012; obliczenia własne. 

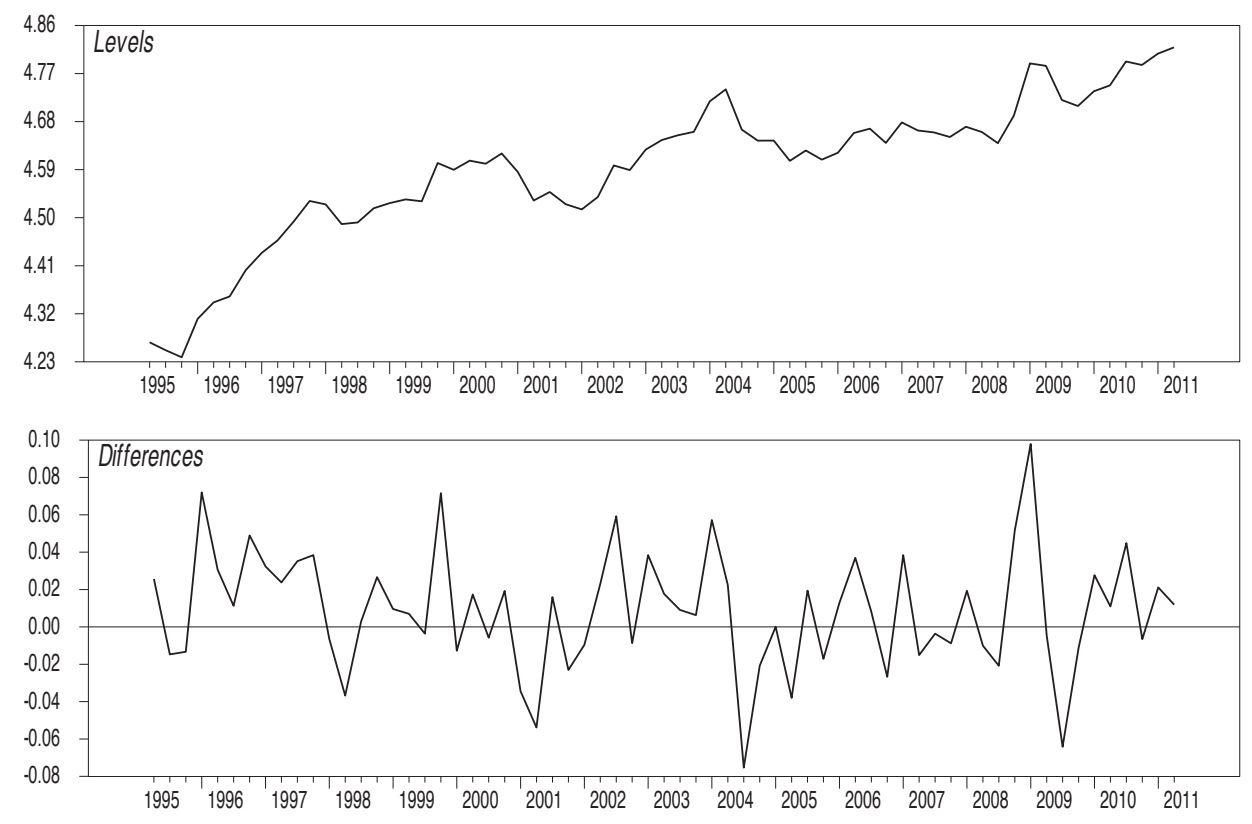

Wykres 4.4e. Wskaźniki cen transakcyjnych importu (2000 r. = 100) oraz ich pierwsze przyrosty, I kwartał 1995 - II kwartał 2011 r.

Źródło: jak do wykresu 4.4a.

\subsubsection{Wyniki oszacowań NAIRU dla Polski}

Jak wspomniano w podrozdziale 4.3.1, wektor zmiennych wykorzystywanych w modelu jest następujący: $X_{t}=\left[W R_{t}, Y_{t}, D C P I_{t}, P M_{t}, U_{t}\right]$; gdzie: $t=1995: 2$ $-2011: 2$.

Wyjściowa wersja modelu została oszacowana dla $k=2$ opóźnień oraz bez żadnych warunków ograniczających dla wyrazu wolnego ${ }^{6}$. Wyniki oszacowań modelu przedstawiono w Aneksie, w tab. A1. W każdym równaniu występuje ten sam zestaw zmiennych objaśniających.

W większości przypadków nie ma przesłanek teoretycznych dotyczących liczby opóźnień w modelu VAR. Aby upewnić się co do poprawności wyboru rzędu-liczby opóźnień, należy kierować się właściwościami statystycznymi modelu. Dla określenia liczby opóźnień można skorzystać z tzw. kryteriów informacyjnych, testów na istotność parametrów oraz analizy właściwości składnika losowego dotyczących autokorelacji, normalności rozkładu. Do wyznaczenia optymalnej liczby opóźnień stosuje się: kryterium Schwartza, kryterium Hannana-Quinna oraz kryterium Akaike. Wyniki testów dla liczby opóźnień przedstawiono w tab. 4.3. Wynika

\footnotetext{
${ }^{6} \mathrm{~W}$ modelach tego typu najczęściej przyjmuje się opóźnienia dwóch kwartałów (zob. np. Kelm 2009, s. 109).
} 
$\mathrm{z}$ nich, że optymalny rząd opóźnień $\mathrm{w}$ analizowanym modelu wynosi $k=2$ (wiersz ten zaznaczono pogrubioną czcionką - wybór optymalny dla $k=2$, ponieważ $\mathrm{LM}(k)>\mathrm{LM}(1))$. W dalszych analizach przyjęty więc będzie rząd opóźnień $k=2$.

Tabela 4.3. Testowanie liczby opóźnień w modelu VAR

\begin{tabular}{|c|c|c|c|c|c|c|c|c|}
\hline Model & $k$ & $\mathrm{~T}$ & Regr & Log-Lik & $\mathrm{SC}$ & H-Q & LM(1) & $\mathrm{LM}(k)$ \\
\hline $\operatorname{VAR}(4)$ & 4 & 61 & 24 & 1467,606 & $-40,031$ & $-42,556$ & 0,503 & 0,055 \\
\hline $\operatorname{VAR}(3)$ & 3 & 61 & 19 & 1436,688 & $-40,702$ & $-42,701$ & 0,023 & 0,014 \\
\hline VAR(2) & 2 & 61 & 14 & 1404,429 & $-41,329$ & $-42,802$ & 0,010 & 0,078 \\
\hline $\operatorname{VAR}(1)$ & 1 & 61 & 9 & 1370,501 & $-41,902$ & $-42,849$ & 0,012 & 0,012 \\
\hline \multicolumn{9}{|c|}{ Testy redukcji liczby opóźnień: } \\
\hline \multicolumn{9}{|c|}{$\operatorname{VAR}(3)<<\operatorname{VAR}(4): \operatorname{ChiSqr}(25)=61,837[0.000]$} \\
\hline \multicolumn{9}{|c|}{$\operatorname{VAR}(2)<<\operatorname{VAR}(4): \operatorname{ChiSqr}(50)=126,355[0.000]$} \\
\hline \multicolumn{9}{|c|}{$\operatorname{VAR}(2)<<\operatorname{VAR}(3): \operatorname{ChiSqr}(25)=64,518[0.000]$} \\
\hline \multicolumn{9}{|c|}{$\operatorname{VAR}(1)<<\operatorname{VAR}(4): \operatorname{ChiSqr}(75)=194,210[0.000]$} \\
\hline \multicolumn{9}{|c|}{$\operatorname{VAR}(1)<<\operatorname{VAR}(3): \operatorname{ChiSqr}(50)=132,373[0.000]$} \\
\hline \multicolumn{9}{|c|}{$\operatorname{VAR}(1)<<\operatorname{VAR}(2): \operatorname{ChiSqr}(25)=67,855[0.000]$} \\
\hline
\end{tabular}

SC - kryterium Schwartza, H-Q - kryterium Hannana-Quinna, LM $(k)$ - LM-test autokorelacji przy danym opóźnieniu $k$.

Źródło: jak do wykresów 4.4a-4.4e; obliczenia własne.

Tabela 4.4. Wyniki testu wykluczeń dla modelu VAR z trendem

\begin{tabular}{|ccccccccc|}
\hline$r$ & $D G F$ & $5 \%$ C.V. & $W R$ & $Y$ & $D C P I$ & $P M$ & $U$ & TREND \\
1 & 1 & 3,841 & 17,768 & 20,302 & 18,623 & 9,746 & 2,522 & 10,231 \\
& & & {$[0,000]$} & {$[0,000]$} & {$[0,000]$} & {$[0,002]$} & {$[0,112]$} & {$[0,001]$} \\
2 & 2 & 5,991 & 29,145 & 33,442 & 24,150 & 10,041 & 8,083 & 17,353 \\
& & & {$[0,000]$} & {$[0,000]$} & {$[0,000]$} & {$[0,007]$} & {$[0,018]$} & {$[0,000]$} \\
3 & 3 & 7,815 & 32,969 & 40,067 & 34,087 & 20,360 & 9,062 & 17,497 \\
& & & {$[0,000]$} & {$[0,000]$} & {$[0,000]$} & {$[0,000]$} & {$[0,028]$} & {$[0,001]$} \\
4 & \multirow{2}{*}{4} & 9,488 & 33,697 & 42,138 & 34,487 & 20,401 & 11,759 & 19,539 \\
& & & {$[0,000]$} & {$[0,000]$} & {$[0,000]$} & {$[0,000]$} & {$[0,019]$} & {$[0,001]$} \\
\hline
\end{tabular}

LR-test, $\chi^{2}(r)$, w nawiasach kwadratowych podano wartości prawdopodobieństw testowych ( $p$-value).

Źródło: jak do wykresów 4.4a-4.4e; obliczenia własne.

Po wyznaczeniu długości opóźnień należy sprawdzić, czy reszty wszystkich równań modelu VAR mają pożądane właściwości, tj. czy charakteryzują się brakiem autokorelacji oraz mają rozkład normalny. Podstawowym i minimalnym wymaganiem w stosunku do reszt jest ich stacjonarność (zob. Kusideł 2000, s. 26). Analiza rozkładu reszt wskazuje, że są one stacjonarne. Nie występuje problem autokorelacji reszt. Sprawdzono też występowanie obserwacji nietypowych. 
Tabela 4.5. Wyniki estymacji modelu VAR z dodanym trendem

Oszacowania parametrów macierzy $\beta$

\begin{tabular}{|lrrrrrr|}
\hline & $W R$ & $Y$ & $D C P I$ & $P M$ & $U$ & \multicolumn{1}{c|}{ TREND } \\
\hline Beta(1) & 19,260 & $-60,351$ & $-120,443$ & 10,141 & 12,078 & 0,241 \\
\hline Beta(2) & $-13,244$ & 37,033 & $-64,196$ & 2,655 & $-26,094$ & $-0,228$ \\
\hline Beta(3) & $-4,809$ & 5,299 & $-95,883$ & $-18,477$ & $-12,775$ & 0,036 \\
\hline Beta(4) & $-6,717$ & $-20,606$ & 13,509 & 0,483 & 44,212 & 0,295 \\
\hline Beta(5) & 13,450 & $-18,364$ & 76,969 & $-11,258$ & 22,160 & 0,195 \\
\hline
\end{tabular}

Oszacowania parametrów macierzy $\alpha$

\begin{tabular}{|lccccc|}
\hline & Alpha(1) & Alpha(2) & Alpha(3) & Alpha(4) & Alpha(5) \\
\hline DWR & $-0,003$ & $-0,003$ & 0,003 & $-0,001$ & $-0,003$ \\
& $(-1,891)$ & $(-2,056)$ & $(1,709)$ & $(-0,720)$ & $(-1,723)$ \\
\hline$D Y$ & 0,006 & $-0,003$ & 0,001 & 0,001 & $-0,001$ \\
& $(6,781)$ & $(-2,992)$ & $(0,680)$ & $(1,339)$ & $(-0,577)$ \\
\hline DDCPI & 0,003 & 0,004 & 0,001 & 0,000 & 0,000 \\
& $(4,411)$ & $(5,170)$ & $(1,238)$ & $(0,483)$ & $(0,490)$ \\
\hline$D P M$ & 0,003 & $-0,005$ & 0,013 & $-0,001$ & 0,003 \\
& $(0,826)$ & $(-1,529)$ & $(4,051)$ & $(-0,324)$ & $(0,834)$ \\
\hline$D U$ & 0,002 & $-0,001$ & $-0,001$ & $-0,001$ & $-0,000$ \\
& $(4,456)$ & $(-1,402)$ & $(-1,306)$ & $(-2,337)$ & $(-0,086)$ \\
\hline
\end{tabular}

Oszacowania parametrów macierzy $\Pi$

\begin{tabular}{|lcccccc|}
\hline & $W R$ & $Y$ & $D C P I$ & $P M$ & $U$ & TREND \\
\hline$D W R$ & $-0,054$ & 0,142 & 0,081 & $-0,056$ & $-0,093$ & $-0,001$ \\
& $(-1,267)$ & $(1,227)$ & $(0,290)$ & $(-1,545)$ & $(-1,041)$ & $(-0,978)$ \\
\hline$D Y$ & 0,144 & $-0,511$ & $-0,686$ & 0,053 & 0,189 & 0,003 \\
& $(5,326)$ & $(-7,003)$ & $(-3,888)$ & $(2,304)$ & $(3,373)$ & $(5,398)$ \\
\hline$D D C P I$ & 0,010 & $-0,060$ & $-0,645$ & 0,021 & $-0,045$ & 0,000 \\
& $(0,493)$ & $(-1,145)$ & $(-5,090)$ & $(1,260)$ & $(-1,112)$ & $(0,351)$ \\
\hline$D P M$ & 0,095 & $-0,295$ & $-1,040$ & $-0,252$ & 0,007 & 0,002 \\
& $(1,067)$ & $(-1,229)$ & $(-1,791)$ & $(-3,330)$ & $(0,039)$ & $(1,562)$ \\
\hline$D U$ & 0,068 & $-0,151$ & $-0,195$ & 0,035 & 0,001 & 0,000 \\
& $(4,439)$ & $(-3,649)$ & $(-1,953)$ & $(2,721)$ & $(0,031)$ & $(1,319)$ \\
\hline
\end{tabular}

Własności modelu

Próba:

Efektywna próba:

Liczba obserwacji - liczba zmiennych:

Zmienne:

Zmienne zero-jedynkowe ${ }^{7}$ :

Stała/trend:

Liczba zmiennych sezonowych:

Liczba opóźnień:

Log-Likelihood $=1502,539$.

Źródło: jak do tab. 4.3; obliczenia własne.
II kwartał 1995 - II kwartał 2011 (65 obserwacji) IV kwartał 1995 - II kwartał 2011 (63 obserwacje) 45

WR Y DCPI PM U

DUM9901\{0\} DUM9601\{0\} DUM9504\{0\} trend

4

2

${ }^{7}$ DUM9901 - zmienna zero-jedynkowa przyjmująca wartość 0 w I kwartale 1999 r.; DUM9601 - zmienna zero-jedynkowa przyjmująca wartość 0 w I kwartale 1996 r.; DUM9504 - zmienna zero-jedynkowa przyjmująca wartość $0 \mathrm{w}$ IV kwartale $1995 \mathrm{r}$. 
W następnym etapie sprawdzono, czy w modelu powinien być uwzględniony trend. Do tego celu wykorzystano test wykluczeń (jego wyniki przedstawiono w tab. 4.4). Jego wyniki wskazują, że niezależnie od liczby wektorów kointegrujących trend nie powinien być wyłączony z przestrzeni kointegrującej (wartości prawdopodobieństwa testowego w każdym przypadku dla trendu jest równa bądź bliska 0).

$\mathrm{Na}$ podstawie analizy reszt stwierdzono występowanie obserwacji nietypowych w IV kwartale 1995 r., I kwartale 1996 r. oraz I kwartale 1999 r. Dla poprawienia własności stochastycznych składnika losowego włączono trzy zmienne zero-jedynkowe w tych kwartałach. Wyniki estymacji modelu VAR z dodaną linią trendu oraz zmiennymi zero-jedynkowymi przedstawiono $\mathrm{w}$ tab. 4.5 . W porównaniu ze wstępnymi oszacowaniami przedstawionymi w tab. A1 uzyskano wyższą wartość wskaźnika zlogarytmowanej wiarygodności, co wskazuje na lepsze dopasowanie modelu do danych empirycznych.

$\mathrm{Na}$ podstawie przeprowadzonych testów, których wyniki przedstawiono w Aneksie, w tab. A2, można stwierdzić, że nie ma poważniejszych zastrzeżeń do rozkładu reszt w modelu, którego wyniki oszacowań przedstawiono w tab. 4.3. Reszty mają rozkład normalny oraz dla poszczególnych równań nie występują istotne problemy z ich autokorelacją. Wykresy reszt dla poszczególnych równań przedstawiono w Aneksie na wykresie A1.

Na podstawie dotychczasowych analiz otrzymano model VAR $\mathrm{z}$ dwoma opóźnieniami oraz ze składnikiem losowym spełniającym podstawowe założenia schematu Gaussa-Markova. W przestrzeni kointegrującej uwzględniono trend jako aproksymantę zmian instytucjonalnych na rynku pracy oraz zmian zachodzących w gospodarce, np. postępu technicznego, szoków popytowych i szoków podażowych.

Po określeniu rzędu opóźnień oraz zbadaniu reszt można przystąpić do wyboru rzędu kointegracji, określenia zmiennych słabo egzogenicznych oraz zbadania innych własności statystycznych. Rząd kointegracji zbadany zostanie w modelu, w którym uwzględnione będą zmienne zero-jedynkowe oraz w modelu bez zmiennych zero-jedynkowych.

Na podstawie analizy danych zawartych w tab. A3 można stwierdzić, że występuje jeden bądź dwa wektory w przestrzeni kointegrującej.

Wartości bezwzględne pierwiastków macierzy towarzyszącej wskazują również na występowanie jednego lub dwóch wektorów kointegrujących (patrz wartości bezwzględne pierwiastków macierzy towarzyszącej).

Potwierdzeniem trafności dokonanego wyboru dwóch wektorów kointegrujących są wyniki testu wykluczenia oraz testu stacjonarności zmiennych. Ich wyniki przedstawiono w tab. A4. Z analizy poziomów prawdopodobieństwa testowego (ich wartości podano w nawiasach kwadratowych w tab. A4) wynika, że dla $r=1$ stopa bezrobocia $(U)$ może zostać ewentualnie wyłączona $\mathrm{z}$ przestrzeni kointegrującej, natomiast dla $r=2$ żadnej ze zmiennych nie można wyłączyć. $Z$ testu stacjonarności wynika ponadto, że dla $r=1$ lub $r=2$ wszystkie z analizowanych zmiennych nie są stacjonarne. 
Tabela 4.6. Model VAR: zmienna $P M$ słabo egzogeniczna

\begin{tabular}{|c|c|c|c|c|c|c|}
\hline \multicolumn{7}{|c|}{ Oszacowania parametrów macierzy $\beta^{\mathrm{T}}$} \\
\hline & $W R$ & $Y$ & $D C P I$ & $U$ & $P M$ & TREND \\
\hline $\operatorname{Beta}(1)$ & 19,090 & $-59,773$ & $-119,043$ & 11,953 & 10,916 & 0,235 \\
\hline $\operatorname{Beta}(2)$ & $-14,098$ & 38,683 & $-76,746$ & $-28,271$ & $-1,055$ & $-0,223$ \\
\hline $\operatorname{Beta}(3)$ & 9,235 & 17,097 & 35,884 & $-33,509$ & 4,136 & $-0,266$ \\
\hline $\operatorname{Beta}(4)$ & $-7,861$ & 17,516 & $-116,347$ & $-36,860$ & $-3,171$ & $-0,194$ \\
\hline \multicolumn{5}{|c|}{ Oszacowania parametrów macierzy $\alpha$} & & \\
\hline & Alpha(1) & $\operatorname{Alpha}(2)$ & $\operatorname{Alpha(3)}$ & $\operatorname{Alpha(4)}$ & & \\
\hline$D W R$ & $\begin{array}{c}-0,003 \\
(-2,104)\end{array}$ & $\begin{array}{c}-0,002 \\
(-1,588)\end{array}$ & $\begin{array}{c}-0,000 \\
(-0,221)\end{array}$ & $\begin{array}{c}0,004 \\
(2,405)\end{array}$ & & \\
\hline$D Y$ & $\begin{array}{c}0,006 \\
(6,610)\end{array}$ & $\begin{array}{c}-0,003 \\
(-2,829)\end{array}$ & $\begin{array}{c}-0,002 \\
(-1,658)\end{array}$ & $\begin{array}{c}0,000 \\
(0,415)\end{array}$ & & \\
\hline$D D C P I$ & $\begin{array}{c}0,003 \\
(4,458)\end{array}$ & $\begin{array}{c}0,004 \\
(5,397)\end{array}$ & $\begin{array}{c}-0,000 \\
(-0,404)\end{array}$ & $\begin{array}{c}-0,000 \\
(-0,528)\end{array}$ & & \\
\hline$D U$ & $\begin{array}{c}0,002 \\
(4,519)\end{array}$ & $\begin{array}{c}-0,001 \\
(-1,741)\end{array}$ & $\begin{array}{c}0,001 \\
(2,371)\end{array}$ & $\begin{array}{c}0,000 \\
(0,590)\end{array}$ & & \\
\hline \multicolumn{7}{|c|}{ Oszacowanie parametrów macierzy $\Pi$} \\
\hline & $W R$ & $Y$ & $D C P I$ & $U$ & $P M$ & TREND \\
\hline$D W R$ & $\begin{array}{c}-0,059 \\
(-1,453)\end{array}$ & $\begin{array}{c}0,155 \\
(1,364)\end{array}$ & $\begin{array}{c}0,128 \\
(0,453)\end{array}$ & $\begin{array}{c}-0,093 \\
(-1,051)\end{array}$ & $\begin{array}{c}-0,045 \\
(-2,457)\end{array}$ & $\begin{array}{c}-0,001 \\
(-1,188)\end{array}$ \\
\hline$D Y$ & $\begin{array}{c}0,140 \\
(5,534)\end{array}$ & $\begin{array}{c}-0,499 \\
(-6,981)\end{array}$ & $\begin{array}{c}-0,643 \\
(-3,627)\end{array}$ & $\begin{array}{c}0,189 \\
(3,406)\end{array}$ & $\begin{array}{c}0,064 \\
(5,515)\end{array}$ & $\begin{array}{r}0,002 \\
(5,511)\end{array}$ \\
\hline$D D C P I$ & $\begin{array}{c}0,006 \\
(0,354)\end{array}$ & $\begin{array}{c}-0,050 \\
(-0,981)\end{array}$ & $\begin{array}{c}-0,610 \\
(-4,807)\end{array}$ & $\begin{array}{c}-0,045 \\
(-1,133)\end{array}$ & $\begin{array}{c}0,029 \\
(3,539)\end{array}$ & $\begin{array}{c}0,000 \\
(0,121)\end{array}$ \\
\hline$D U$ & $\begin{array}{c}0,069 \\
(4,806)\end{array}$ & $\begin{array}{c}-0,155 \\
(-3,807)\end{array}$ & $\begin{array}{c}-0,209 \\
(-2,077)\end{array}$ & $\begin{array}{c}0,001 \\
(0,035)\end{array}$ & $\begin{array}{c}0,032 \\
(4,868)\end{array}$ & $\begin{array}{c}0,000 \\
(1,528)\end{array}$ \\
\hline
\end{tabular}

Własności modelu:

Próba:

II kwartał 1995 - II kwartał 2011 r. (65 obserwacji)

Efektywna próba:

IV kwartał 1995 - II kwartał 2011 r. (63 obserwacje)

Liczba obserwacji - liczba zmiennych: 44

Zmienne:

WR Y DCPI U

Zmienna słabo egzogeniczna:

$P M$

Zmienne zero-jedynkowe:

Stała/trend:

DUM9901\{0\} DUM9601\{0\} DUM9504\{0\}

Liczba zmiennych sezonowych: trend

Liczba opóźnień:

4

2

Log-Likelihood $=1270,197$

W nawiasach podano wartości statystyk $t$-Studenta.

Źródło: jak do tab. 4.3; obliczenia własne. 
Na zakończenie analizy przeprowadzono test słabej egzogeniczności zmiennych (zob. tab. A5). Dla $r=1$ i $r=2$ zmienna $P M$ (wskaźnik cen transakcyjnych importu - czyli deflator importu) jest słabo egzogeniczna (zmienna ta jest uwzględniona $\mathrm{w}$ wektorze, ale nie ma dla niej równania, które opisywałoby kształtowanie się wskaźnika cen transakcyjnych importu). Zmienna WR (przeciętne wynagrodzenie w ujęciu realnym) dla $r=1$ oraz $r=2$ może zostać uznana za zmienną słabo egzogeniczną na granicznym poziomie istotności.

Tabela 4.7. Model VAR: wyniki estymacji dla dwóch wektorów kointegrujących

\begin{tabular}{|c|c|c|c|c|c|c|}
\hline \multicolumn{7}{|c|}{ Wektory własne (transponowane) } \\
\hline & $W R$ & $Y$ & $D C P I$ & $U$ & $P M$ & TREND \\
\hline $\operatorname{Beta}(1)$ & 19,090 & $-59,773$ & $-119,043$ & 11,953 & 10,916 & 0,235 \\
\hline $\operatorname{Beta}(2)$ & $-14,098$ & 38,683 & $-76,746$ & $-28,271$ & $-1,055$ & $-0,223$ \\
\hline \multicolumn{7}{|c|}{ Oszacowania parametrów macierzy $\beta^{\mathrm{T}}$} \\
\hline & $W R$ & $Y$ & $D C P I$ & $U$ & $P M$ & TREND \\
\hline $\operatorname{Beta}(1)$ & 19,090 & $-59,773$ & $-119,043$ & 11,953 & 10,916 & 0,235 \\
\hline $\operatorname{Beta}(2)$ & $-14,098$ & 38,683 & $-76,746$ & $-28,271$ & $-1,055$ & $-0,223$ \\
\hline
\end{tabular}

Oszacowania parametrów macierzy $\alpha$

\begin{tabular}{|lcc|}
\hline & Alpha(1) & Alpha(2) \\
\hline DWR & $-0,003$ & $-0,002$ \\
& $(-2,013)$ & $(-1,519)$ \\
\hline$D Y$ & 0,006 & $-0,003$ \\
& $(6,461)$ & $(-2,766)$ \\
\hline DDCPI & 0,003 & 0,004 \\
& $(4,442)$ & $(5,378)$ \\
\hline$D U$ & 0,002 & $-0,001$ \\
& $(4,319)$ & $(-1,664)$ \\
\hline
\end{tabular}

Oszacowania parametrów macierzy $\Pi$

\begin{tabular}{|lcccccc|}
\hline & $W R$ & $Y$ & $D C P I$ & $U$ & $P M$ & TREND \\
\hline$D W R$ & $-0,027$ & 0,097 & 0,563 & 0,030 & $-0,032$ & $-0,000$ \\
& $(-0,716)$ & $(0,864)$ & $(2,515)$ & $(0,616)$ & $(-1,857)$ & $(-0,416)$ \\
\hline$D Y$ & 0,158 & $-0,479$ & $-0,540$ & 0,151 & 0,071 & 0,002 \\
& $(6,841)$ & $(-6,927)$ & $(-3,932)$ & $(5,064)$ & $(6,698)$ & $(6,593)$ \\
\hline DDCPI & 0,006 & $-0,039$ & $-0,642$ & $-0,067$ & 0,029 & $-0,000$ \\
& $(0,378)$ & $(-0,807)$ & $(-6,648)$ & $(-3,224)$ & $(3,904)$ & $(-0,473)$ \\
\hline$D U$ & 0,060 & $-0,182$ & $-0,218$ & 0,056 & 0,028 & 0,001 \\
& $(4,463)$ & $(-4,530)$ & $(-2,729)$ & $(3,214)$ & $(4,459)$ & $(4,280)$ \\
\hline
\end{tabular}

Log-Likelihood $=1263,097$

W nawiasach podano wartości statystyk $t$-Studenta.

Źródło: jak do tab. 4.3; obliczenia własne. 
Podobną procedurę weryfikacyjną zastosowano wobec modelu VAR bez zmiennych zero-jedynkowych (zob. tab. A6). Wnioski z analizy dla modelu bez zmiennych zero-jedynkowych są takie same, jak dla modelu ze zmiennymi zero-jedynkowymi. Można uznać deflator importu za zmienną słabo egzogeniczną. Ceny importu zależą przede wszystkim od kursu walutowego, nie zależą natomiast bezpośrednio od pozostałych zmiennych uwzględnionych w modelu. Ponadto, oszacowania parametrów dostosowań dla równania importu (wiersz dla $D P M$ w macierzy alfa) są (poza jednym wyjątkiem) nieistotne statystycznie (zob. tab. 4.5). Na podstawie przeprowadzonych analiz statystycznych zdecydowano się na przyjęcie dwóch wektorów w przestrzeni kointegrującej.

W tab. 4.6 przedstawiono wyniki oszacowań modelu VAR (przed nałożeniem restrykcji), w którym zmienną $P M$ uznano jako słabo egzogeniczną.

$\mathrm{Na}$ wykresie A2 przedstawiono wykresy pięciu wektorów kointegrujących przed nałożeniem restrykcji (chwilowo uchylono założenie o słabej egzogeniczności zmiennej $P M$ ). $\mathrm{Z}$ wykresu $\mathrm{A} 2$ oraz tab. 4.5 wynika, że wektory 3,4 i 5 wydają się niestacjonarne.

Wyniki estymacji składowych dwóch wektorów kointegrujących przedstawiono $\mathrm{w}$ tab. 4.7. Wektory bez restrykcji strukturalizujących mają następującą postać:

$$
\begin{gathered}
19,090 W R-59,773 Y-119,043 D C P I+11,953 U+ \\
+10,916 P M+0,235 T R=0 \\
-14,098 W R+38,683 Y-76,746 D C P I- \\
-28,271 U-1,055 P M-0,223 T R=0
\end{gathered}
$$

Uzyskane wyniki są satysfakcjonujące, a zatem można przejść do nałożenia i przetestowania restrykcji strukturalizujących. W pierwszym etapie nałożono restrykcje zerowe na parametry. Wyniki estymacji modelu z nałożonymi restrykcjami oraz wyniku testu nałożonych restrykcji przedstawiono w tab. 4.8. Przy tych restrykcjach wektory kointegrujące opisane są przez równania (4.14) oraz (4.15):

$$
\begin{gathered}
W R=3,052 Y-1,522 U-0,017 T R \\
D C P I=-0,151 U+0,081 P M-0,001 T R
\end{gathered}
$$

Ponadto, wartość prawdopodobieństwa testowego wynosząca 0,309 dla nałożonych restrykcji wskazuje, że nie ma podstaw do odrzucenia hipotezy, że restrykcje są poprawne. W równaniu (4.14) mamy ponadto pozytywny wpływ zmiany poziomu wydajności pracy na płace i ujemny wpływ trendu $(T R)$. Oznacza to, że poziom wynagrodzeń w ujęciu realnym zależy od odchylenia wydajności pracy od jej długookresowego trendu. 
Tabela 4.8. Model VAR: wyniki estymacji dla dwóch wektorów kointegrujących z nałożonymi restrykcjami strukturalizującymi

\begin{tabular}{|c|c|c|c|c|c|c|}
\hline \multicolumn{7}{|c|}{ Wektory własne (transponowane) } \\
\hline & $W R$ & $Y$ & $D C P I$ & $U$ & $P M$ & TREND \\
\hline $\operatorname{Beta}(1)$ & 23,469 & $-71,618$ & 0,000 & 35,719 & 0,000 & 0,390 \\
\hline $\operatorname{Beta}(2)$ & 0,000 & 0,000 & 132,053 & 19,995 & $-10,750$ & 0,100 \\
\hline \multicolumn{7}{|c|}{ Oszacowania parametrów macierzy $\beta^{\mathrm{T}}$} \\
\hline & $W R$ & $Y$ & $D C P I$ & $U$ & $P M$ & TREND \\
\hline $\operatorname{Beta}(1)$ & $\begin{array}{l}1,000 \\
(, N A)\end{array}$ & $\begin{array}{c}-3,052 \\
(-10,463)\end{array}$ & $\begin{array}{l}0,000 \\
\text { (NA) }\end{array}$ & $\begin{array}{c}1,522 \\
(4,855)\end{array}$ & $\begin{array}{l}0,000 \\
(, N A)\end{array}$ & $\begin{array}{c}0,017 \\
(5,750)\end{array}$ \\
\hline $\operatorname{Beta}(2)$ & $\begin{array}{l}0,000 \\
(, N A)\end{array}$ & $\begin{array}{l}0,000 \\
(, N A)\end{array}$ & $\begin{array}{l}1,000 \\
(, N A)\end{array}$ & $\begin{array}{c}0,151 \\
(4,246)\end{array}$ & $\begin{array}{c}-0,081 \\
(-3,819)\end{array}$ & $\begin{array}{c}0,001 \\
(4,884)\end{array}$ \\
\hline
\end{tabular}

Oszacowania parametrów macierzy $\alpha$

\begin{tabular}{|lcc|}
\hline & Alpha(1) & Alpha(2) \\
\hline DWR & $-0,024$ & 0,525 \\
& $(-0,640)$ & $(2,532)$ \\
\hline$D Y$ & 0,159 & $-0,620$ \\
& $(7,008)$ & $(-4,867)$ \\
\hline DDCPI & 0,012 & $-0,551$ \\
& $(0,741)$ & $(-6,048)$ \\
\hline$D U$ & 0,058 & $-0,258$ \\
& $(4,310)$ & $(-3,440)$ \\
\hline
\end{tabular}

Oszacowania parametrów macierzy $\Pi$

\begin{tabular}{|lcccccc|}
\hline & $W R$ & $Y$ & $D C P I$ & $U$ & $P M$ & TREND \\
\hline DWR & $-0,024$ & 0,072 & 0,525 & 0,044 & $-0,043$ & 0,000 \\
& $(-0,640)$ & $(0,640)$ & $(2,532)$ & $(0,928)$ & $(-2,532)$ & $(0,012)$ \\
\hline DY & 0,159 & $-0,485$ & $-0,620$ & 0,148 & 0,050 & 0,002 \\
& $(7,008)$ & $(-7,008)$ & $(-4,867)$ & $(5,130)$ & $(4,867)$ & $(6,503)$ \\
\hline \multirow{2}{*}{ DDCPI } & 0,012 & $-0,037$ & $-0,551$ & $-0,065$ & 0,045 & $-0,000$ \\
& $(0,741)$ & $(-0,741)$ & $(-6,048)$ & $(-3,160)$ & $(6,048)$ & $(-0,919)$ \\
\hline DU & 0,058 & $-0,176$ & $-0,258$ & 0,049 & 0,021 & 0,001 \\
& $(4,310)$ & $(-4,310)$ & $(-3,440)$ & $(2,856)$ & $(3,440)$ & $(3,870)$ \\
\hline
\end{tabular}

Test modelu z nałożonymi restrykcjami strukturalizującymi: $\chi^{2}(2)=2,349[0,309]$.

Log-Likelihood $=1261,922$.

$\mathrm{W}$ nawiasach okrągłych podano wartości statystyk $t$-Studenta, w nawiasie kwadratowym pod tab. podano wartości prawdopodobieństw testowych.

Źródło: jak do tab. 4.3; obliczenia własne.

Po nałożeniu kolejnych restrykcji strukturalizujących uzyskano ostateczną postać modelu VAR (zob. tab. 4.9) 
Tabela 4.9. Model VAR: ostateczne wyniki estymacji

Wektory własne (transponowane)

\begin{tabular}{|ccccccc|}
\hline & $W R$ & $Y$ & $D C P I$ & $U$ & $P M$ & TREND \\
\hline $\operatorname{Beta}(1)$ & 23,096 & $-72,915$ & 0,000 & 37,568 & 0,000 & 0,410 \\
\hline $\operatorname{Beta}(2)$ & 0,000 & 0,000 & 133,470 & 20,644 & $-10,883$ & 0,104 \\
\hline
\end{tabular}

Oszacowania parametrów macierzy $\beta^{\mathrm{T}}$

\begin{tabular}{|lcccccc|}
\hline & $W R$ & $Y$ & $D C P I$ & $U$ & $P M$ & TREND \\
\hline Beta(1) & 1,000 & $-3,157$ & 0,000 & 1,627 & 0,000 & 0,018 \\
& (NA) & $(-25,736)$ & (NA) & $(7,976)$ & (NA) & $(25,736)$ \\
\hline Beta(2) & 0,000 & 0,000 & 1,000 & 0,155 & $-0,082$ & 0,001 \\
& (NA) & (NA) & (NA) & $(4,491)$ & $(-3,957)$ & $(5,479)$ \\
\hline
\end{tabular}

Oszacowania parametrów macierzy $\alpha$

\begin{tabular}{|lcc|}
\hline & Alpha(1) & Alpha(2) \\
\hline DWR & $-0,024$ & 0,529 \\
& $(-0,653)$ & $(2,516)$ \\
\hline$D Y$ & 0,157 & $-0,622$ \\
& $(7,049)$ & $(-4,844)$ \\
\hline DDCPI & 0,011 & $-0,561$ \\
& $(0,720)$ & $(-6,081)$ \\
\hline$D U$ & 0,056 & $-0,257$ \\
& $(4,204)$ & $(-3,374)$ \\
\hline
\end{tabular}

Oszacowania parametrów macierzy $\Pi$

\begin{tabular}{|lcccccc|}
\hline & $W R$ & $Y$ & $D C P I$ & $U$ & $P M$ & TREND \\
\hline DWR & $-0,024$ & 0,075 & 0,529 & 0,043 & $-0,043$ & $-0,000$ \\
& $(-0,653)$ & $(0,653)$ & $(2,516)$ & $(0,861)$ & $(-2,516)$ & $(-0,014)$ \\
\hline$D Y$ & 0,157 & $-0,495$ & $-0,622$ & 0,159 & 0,051 & 0,002 \\
& $(7,049)$ & $(-7,049)$ & $(-4,844)$ & $(5,189)$ & $(4,844)$ & $(6,530)$ \\
\hline \multirow{2}{*}{$D D C P I$} & 0,011 & $-0,036$ & $-0,561$ & $-0,068$ & 0,046 & $-0,000$ \\
& $(0,720)$ & $(-0,720)$ & $(-6,081)$ & $(-3,095)$ & $(6,081)$ & $(-0,929)$ \\
\hline$D U$ & 0,056 & $-0,175$ & $-0,257$ & 0,051 & 0,021 & 0,001 \\
& $(4,204)$ & $(-4,204)$ & $(-3,374)$ & $(2,780)$ & $3,374)$ & $(3,756)$ \\
\hline
\end{tabular}

Test modelu (ostateczne wyniki): $\chi^{2}(2)=2,472[0,480]$.

Log-Likelihood $=1261,861$.

W nawiasach okrągłych podano wartości statystyk $t$-Studenta, w nawiasie kwadratowym pod tab. podano wartość prawdopodobieństw testowych.

Źródło: jak do tab. 4.3; obliczenia własne. 
Wartość testu dla nałożonych restrykcji strukturalizujących w tab. 4.9 wskazuje, że nie ma podstaw do odrzucenia restrykcji (prawdopodobieństwo testowe wynosi 0,480 ). Wektory z nałożonymi restrykcjami przedstawiono na wykresie aA3, z którego wynika, że oba wektory są stacjonarne. Równania tych wektorów kointegrujących są następującej postaci.

$$
\begin{gathered}
W R=3,157 Y-1,627 U-0,018 T R \\
D C P I=-0,155 U+0,082 P M-0,001 T R
\end{gathered}
$$

Z równania (4.17) wynika, że przy innych czynnikach niezmienionych wzrost stopy bezrobocia o 1 punkt procentowy spowoduje spadek DCPI (czyli potocznie stopy inflacji) o $0,155 \%$. Natomiast wzrost wskaźnika cen transakcyjnych importu o $1 \%$ spowoduje przy innych czynnikach niezmienionych wzrost DCPI o $0,082 \%$.

Układ równań (4.16-4.17) wykorzystano do wyznaczenia kwartalnych stóp bezrobocia NAIRU w Polsce w okresie III kwartał 1995 - II kwartał 2011 (zob. wykres 4.5). Uzyskane szacunki NAIRU wynikają z zestawu danych statystycznych, a nie z przyjętych założeń.

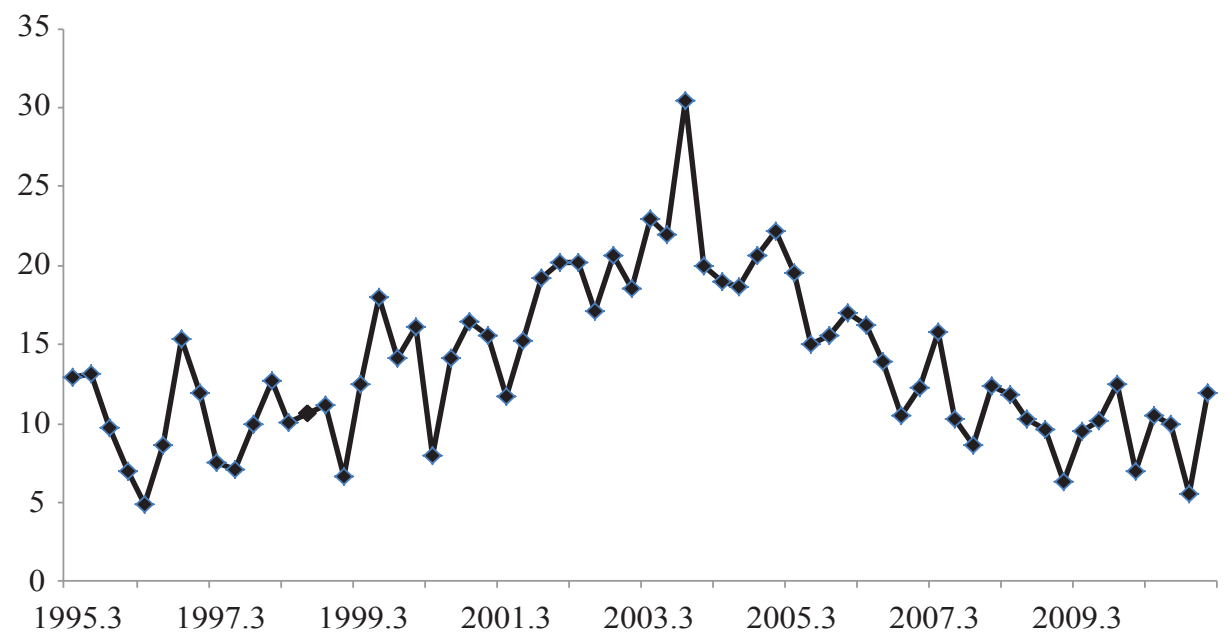

Wykres 4.5. Oszacowania krótkookresowej stopy bezrobocia NAIRU*, III kwartał 1995 - II kwartał 2011 r. (w \%)

* dane niewygładzone.

Źródło: jak do tab. 4.3; obliczenia własne.

Jak wynika z wykresu 4.5, oszacowany poziom NAIRU cechował się bardzo silną zmiennością (współczynnik zmienności wyniósł 37\%). Dlatego też wyznaczony szereg kwartalnych stóp bezrobocia NAIRU wygładzono przy pomocy testu 
Hodricka-Prescotta. Wygładzone kwartalne stopy bezrobocia NAIRU oraz faktyczne stopy bezrobocia według BAEL przedstawiono na wykresie 4.6.

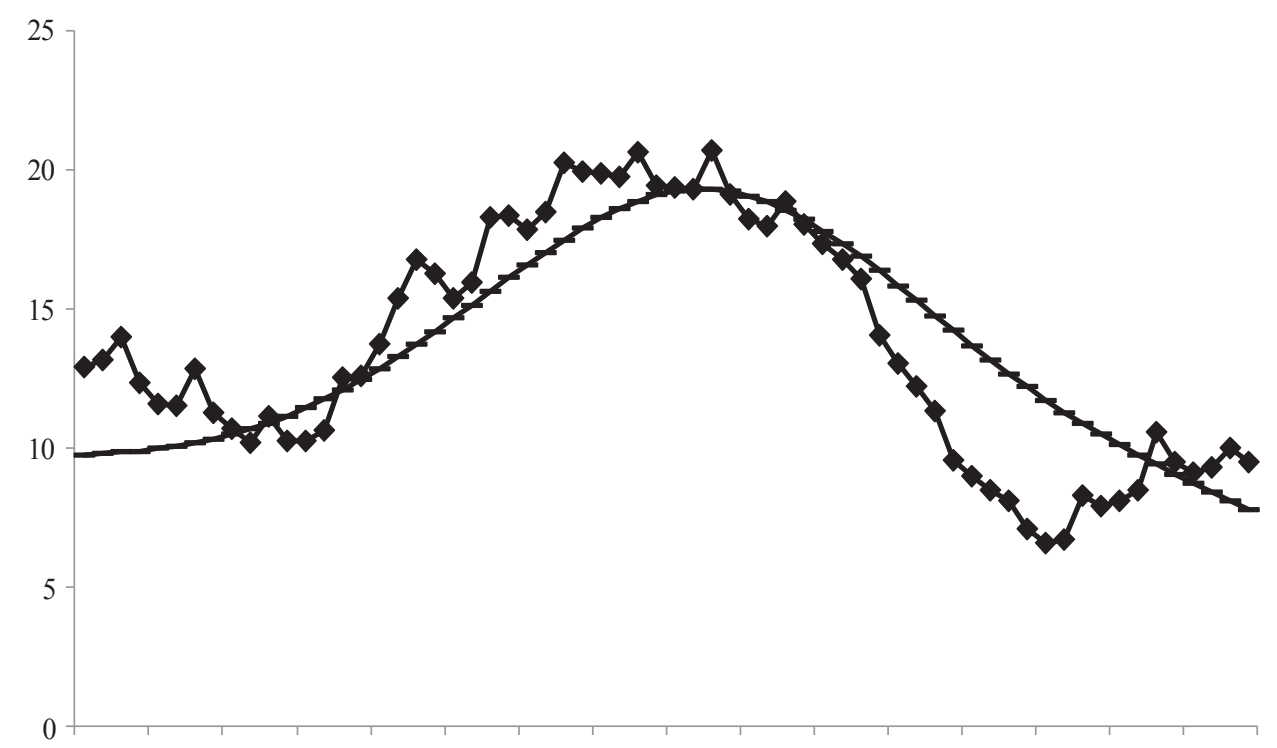

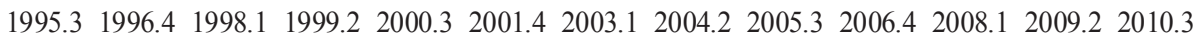

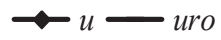

Wykres 4.6. Faktyczne stopy bezrobocia według BAEL oraz wygładzone stopy bezrobocia

NAIRU (uro), III kwartał 1995 - II kwartał 2011 r. (w \%)

$u$ - faktyczna stopa bezrobocia, uro - wygładzona stopa bezrobocia NAIRU.

Źródło: jak do tab. 4.3; obliczenia własne.

Analiza szacunków stóp bezrobocia NAIRU w Polsce obejmujących okres III kwartał 1995 - II kwartał 2011 (zob. wykres 4.6) pozwala sformułować poniższe wnioski.

Stopa bezrobocia równowagi prawie w całym analizowanym okresie zmieniała się w tym samym kierunku, co faktyczna stopa bezrobocia ${ }^{8}$. Zbliżone wyniki uzyskali K. Leszkiewicz-Kędzior i W. Welfe (2013)9.

Do I kwartału 1998 r. (za wyjątkiem IV kwartału 1997 r.) faktyczna stopa bezrobocia była niższa od stopy bezrobocia NAIRU. Natomiast od II do IV kwartału 1998 r. stopa bezrobocia NAIRU była wyższa od faktycznej stopy bezrobo-

\footnotetext{
${ }^{8}$ Wyjątek stanowi okres IV kwartał 2008 - I kwartał 2010 r., wówczas wzrostowi faktycznej stopy bezrobocia towarzyszył spadek stopy bezrobocia NAIRU.

${ }^{9}$ Wyniki przedstawione przez Kelma (2009) są podobne w odniesieniu do tendencji zmian stopy bezrobocia NAWRU i faktycznej stopy bezrobocia. Kelm uzyskał odmienne relacje między NAWRU i faktyczną stopą bezrobocia w niektórych podokresach.
} 
cia, co wskazuje na osłabienie presji inflacyjnej w tym okresie. Od I kwartału 1999 r. do I kwartału 2004 r. (za wyjątkiem IV kwartału 2003 r.) faktyczna stopa bezrobocia przewyższała stopę bezrobocia równowagi. Wraz z osłabieniem koniunktury gospodarczej wzrastało bowiem znaczenie bezrobocia cyklicznego. Relacja między stopą bezrobocia równowagi i faktyczną stopą bezrobocia uległa odwróceniu w okresie II kwartał 2004 - IV kwartał 2009 r. Wraz z przyspieszeniem tempa wzrostu gospodarczego oraz otwarciem rynków pracy niektórych krajów UE w Polsce znacznie zmalało bezrobocie faktyczne i bezrobocie równowagi. Należy zwrócić uwagę, że do końca 2005 r. nadwyżka NAIRU ponad faktyczną stopę bezrobocia była stosunkowo niewielka, zaś w latach 2006-2008 znacząco wzrosła (zob. wykres 4.7). Można wysnuć wniosek, że w tym okresie w Polsce mieliśmy do czynienia z rynkiem pracownika. Przyczyną tego stanu była bardzo duża skala migracji zarobkowych. Jak wynika z rozdziału drugiego, skala migracji zagranicznych była największa.

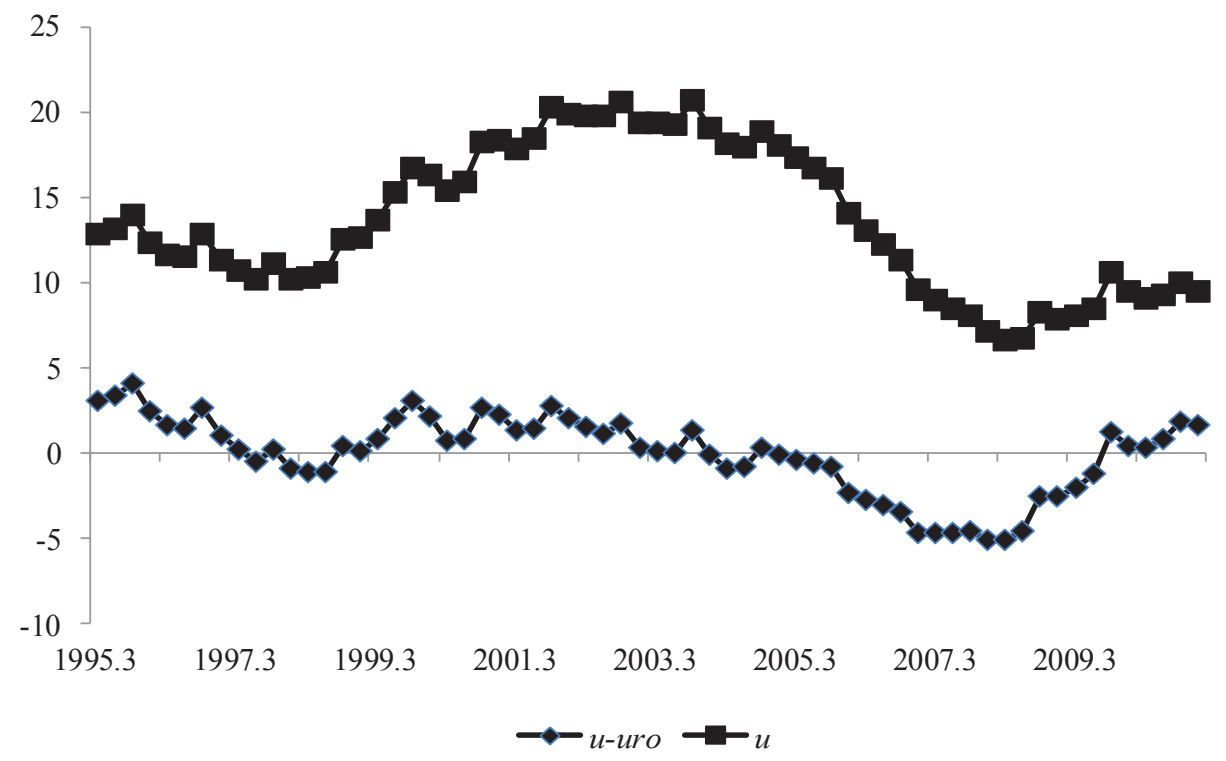

Wykres 4.7. Faktyczne stopy bezrobocia według BAEL oraz różnica między faktyczną stopą bezrobocia a wygładzoną stopą bezrobocia NAIRU (uro), III kwartał 1995 - II kwartał 2011 r.

uro - wygładzona stopa bezrobocia NAIRU, $u$ - faktyczna stopa bezrobocia.

Źródło: jak do tab. 4.3; obliczenia własne.

Od I kwartału 2010 do II kwartału 2011 r. faktyczna stopa bezrobocia przewyższała stopę bezrobocia równowagi. Pogorszenie sytuacji na rynku pracy w Polsce było spowodowane negatywnymi zmianami w otoczeniu polskiej gospodarki. 
Światowy kryzys finansowy nie przełożył się jednak na wzrost NAIRU wyznaczonego w oparciu o rozszerzoną krzywą Phillipsa, tak jak to nastąpiło w niektórych krajach ${ }^{10}$.

Przyjrzyjmy się, jak na poziom wyznaczonych stóp bezrobocia NAIRU w Polsce wpływał poziom aktywności zawodowej oraz udział bezrobotnych długookresowo.

Według R. Layarda przyspieszona dezaktywizacja zasobów pracy (wcześniejsze emerytury, łatwiejszy dostęp do zasiłków przedemerytalnych) może prowadzić do skutków odwrotnych od zakładanych w polityce makroekonomicznej. Zmniejszenie poziomu aktywności zawodowej może skutkować obniżeniem efektywnej podaży siły roboczej, lecz niekoniecznie będzie prowadzić do obniżenia poziomu bezrobocia. Trudno jest zastąpić osoby starsze, często z wysokimi kwalifikacjami, bezrobotnymi, którzy nie posiadają specyficznych kwalifikacji potrzebnych w danych przedsiębiorstwach. Efektem takich działań będzie nasilenie żądań płacowych ze strony pracowników, którzy przejściowo będą wykonywać część pracy za zwolnionych pracowników (zob. Layard 1996, s. 22).

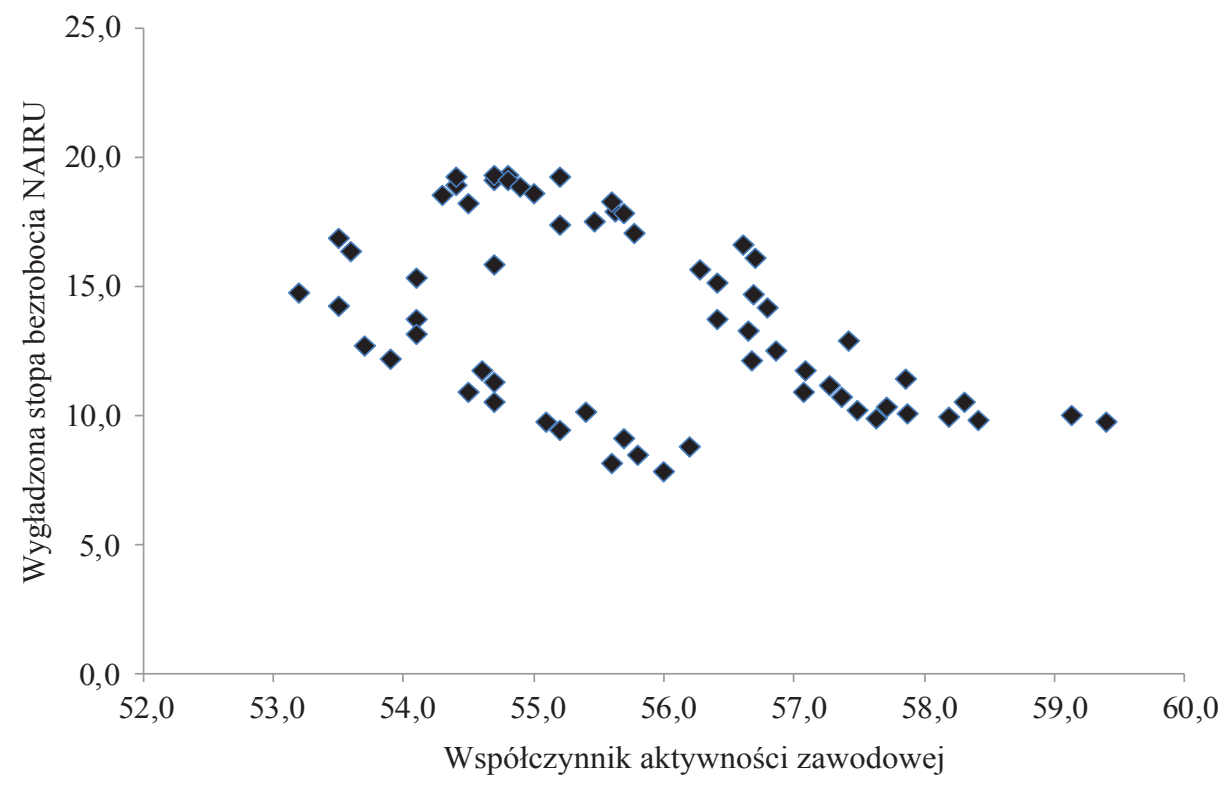

Wykres 4.8. Zależność między wygładzoną stopą bezrobocia NAIRU a współczynnikami aktywności zawodowej w Polsce, III kwartał 1995 - II kwartał 2011 r. (w \%)

Źródło: jak do tab. 4.3; obliczenia własne.

${ }^{10}$ Co prawda oszacowania NAIRU w oparciu o metody przepływów wskazują na wzrost stopy bezrobocia równowagi w latach 2008-2009, niemniej uzyskane wyniki budzą pewne wątpliwości. M. Daly, B. Hobijn, R. Valletta szacują, że w wyniku światowego kryzysu finansowego stopa bezrobocia równowagi w USA wzrosła od 0,6 do 1,9 punktu procentowego (zob. Daly, Hobijn, Valletta 2011, s. 25). 
Teoria histerezy wskazuje, iż poziom bezrobocia równowagi może podążać za faktyczną stopą bezrobocia. Bezrobotni długookresowo mają mniejsze szanse znalezienia pracy, a zatem wzrost odsetka bezrobotnych długookresowo powinien prowadzić do wzrostu poziomu bezrobocia równowagi.

Jak wynika z wykresu 4.8, poziom stopy bezrobocia równowagi w analizowanym okresie był ujemnie skorelowany z poziomem współczynnika aktywności zawodowej. Wzrost współczynnika aktywności zawodowej powoduje bowiem osłabienie presji płacowej i tym samym zmniejszenie bezrobocia równowagi. Należy zwrócić uwagę na pewne rozproszenie punktów na wykresie. Przyczyn tego stanu można upatrywać $\mathrm{w}$ zmianie metodologii stosowanej $\mathrm{w}$ ciągu badanego okresu w badaniach aktywności ekonomicznej ludności i w nasileniu emigracji zarobkowej po wejściu Polski do UE.

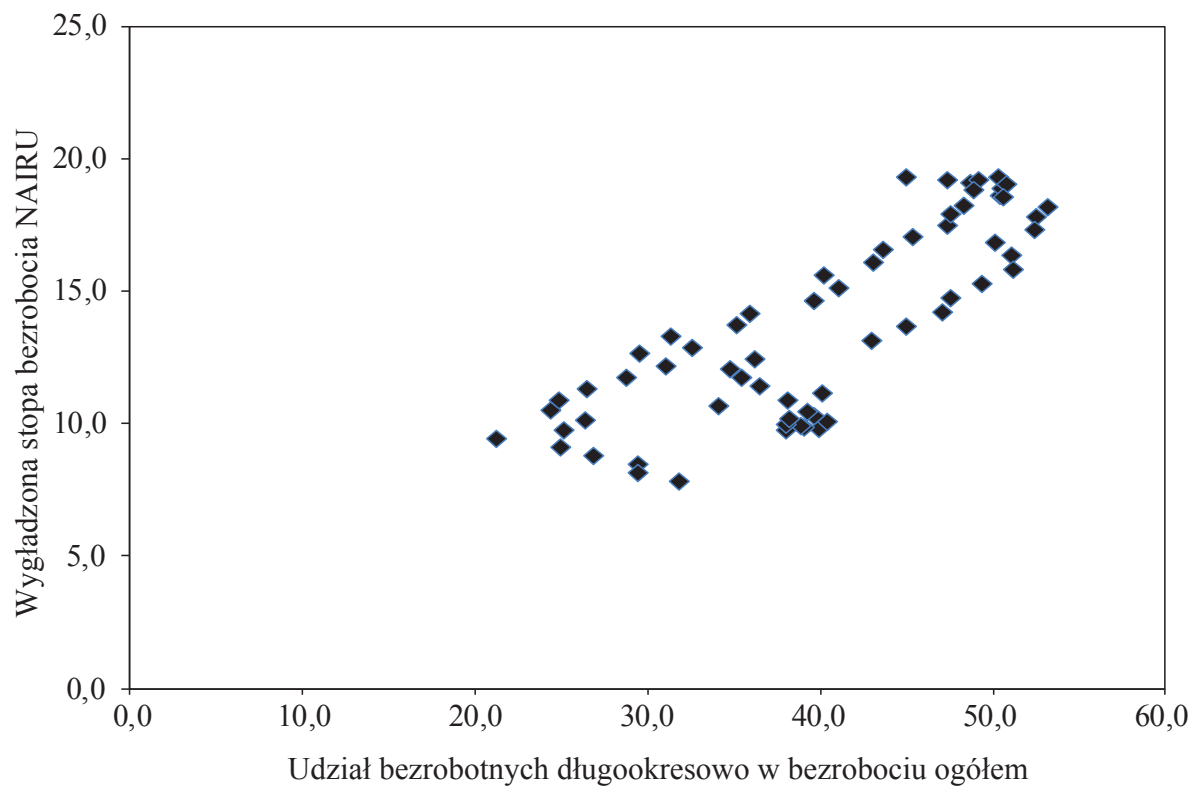

Wykres 4.9. Zależność między wygładzoną stopą bezrobocia NAIRU a udziałem bezrobotnych długookresowo w bezrobociu ogółem w Polsce, III kwartał 1995 - II kwartał 2011 r. (w \%)

Źródło: jak do tab. 4.3; obliczenia własne.

W analizowanym okresie występowała dodatnia korelacja między poziomem bezrobocia równowagi a udziałem bezrobotnych długookresowo (zob. wykres 4.9). Jest to zgodne $z$ teorią ekonomii, ponieważ wzrost odsetka bezrobotnych długookresowo powoduje wzrost presji płacowej.

Współczynnik korelacji między stopą bezrobocia NAIRU a udziałem bezrobotnych długookresowo w bezrobociu ogółem wynosił w badanym okresie 0,817. To wskazuje, że na poziom NAIRU bardzo silnie wpływały zmiany odsetka bezrobotnych długookresowo. Może to wskazywać na występowanie 
zjawiska histerezy bezrobocia. Wniosek ten znajduje potwierdzenie $\mathrm{w}$ innych badaniach, z których wynika, że w Polsce w latach 1993-2008 występowała w Polsce częściowa histereza bezrobocia (zob. Kwiatkowski, Rogut, Roszkowska 2009, s. 191).

\subsection{Podsumowanie}

Z przeprowadzonych rozważań wynikają następujące wnioski.

Po pierwsze, wyniki oszacowań NAIRU dla Polski uzyskane przez różnych autorów, z uwagi na zastosowanie różnych metod, niekiedy znacznie różnią się między sobą. Wydaje się, że najbardziej wiarygodne wyniki oszacowań uzyskano na podstawie estymacji modeli typu VAR.

Po drugie, z uzyskanych przez autora niniejszej rozprawy oszacowań bezrobocia równowagi w oparciu o metody przepływów oraz o rozszerzoną krzywą Phillipsa wynika, że w badanym okresie utrzymywał się wysoki poziom bezrobocia równowagi w Polsce.

Po trzecie, z porównania wyników oszacowań bazujących na metodach przepływów z wynikami uzyskanymi w tym rozdziale wynika, że do 2004 r. oszacowania stóp bezrobocia równowagi dla Polski w oparciu o metody przepływów w nieznacznym stopniu odbiegały od oszacowań uzyskanych w oparciu o rozszerzoną krzywą Phillipsa. Natomiast w latach 2004-2009 występowały dosyć duże różnice między wynikami uzyskanymi w oparciu o obie metody. Przyczyną tych różnic może być znaczny wzrost przepływów migracyjnych z Polski po otwarciu rynków pracy UE.

Po czwarte, otrzymane oszacowania NAIRU w okresie III kwartał 1995 - II kwartał 2011 r. w oparciu o rozszerzoną krzywą Phillipsa wskazują, że wówczas stopy bezrobocia równowagi zmieniały się w tym samym kierunku, co faktyczna stopa bezrobocia. W okresie III kwartał 1995 - III kwartał 1997 r. faktyczna stopa bezrobocia była wyższa niż stopa bezrobocia NAIRU. Od IV kwartału 1997 do IV kwartału 1998 r. (za wyjątkiem I kwartału 1998 r.) stopa bezrobocia NAIRU przewyższała faktyczną stopę bezrobocia. Również w okresie od I kwartału 1999 do I kwartału 2004 r. faktyczna stopa bezrobocia była wyższa od NAIRU. Od II kwartału 2004 do IV kwartału 2009 r. relacja między NAIRU a faktyczną stopą bezrobocia uległa odwróceniu. Z kolei od I kwartału 2010 do II kwartału 2011 r. faktyczna stopa bezrobocia była wyższa od NAIRU.

Po piąte, z przeprowadzonych analiz empirycznych wynika, że w badanym okresie występowała dosyć silna ujemna zależność między stopą bezrobocia NAIRU a współczynnikami aktywności zawodowej w Polsce.

Po szóste, w analizowanym okresie występowała silna dodatnia zależność między NAIRU a udziałem bezrobotnych długookresowo, co może wskazywać na występowanie histerezy bezrobocia. 


\section{Aneks}

Tabela A1. Wyniki estymacji modelu z nieograniczonym wyrazem wolnym

Oszacowania parametrów macierzy $\beta^{\text {T }}$ Wr
\begin{tabular}{|lrrrrr|}
\hline \multicolumn{7}{|c|}{$W R$} & $Y$ & $D C P I$ & \multicolumn{1}{c|}{$P M$} & \multicolumn{1}{c|}{$U$} \\
\hline Beta(1) & $-13,009$ & 27,536 & 147,030 & $-1,724$ & 16,981 \\
\hline $\operatorname{Beta}(2)$ & $-19,150$ & 27,453 & $-59,653$ & $-13,630$ & $-11,272$ \\
\hline $\operatorname{Beta}(3)$ & 1,905 & $-0,216$ & 32,720 & $-7,907$ & 4,394 \\
\hline $\operatorname{Beta}(4)$ & $-17,068$ & 6,022 & $-17,422$ & 14,572 & $-6,556$ \\
\hline $\operatorname{Beta}(5)$ & $-1,624$ & $-1,668$ & $-29,611$ & 2,562 & 20,868 \\
\hline
\end{tabular}

Oszacowania parametrów macierzy $\alpha$

\begin{tabular}{|lccccc|}
\hline & Alfa(1) & Alfa(2) & Alfa(3) & Alfa(4) & Alfa (5) \\
\hline DWR & $-0,007$ & 0,004 & 0,003 & 0,008 & $-0,001$ \\
& $(-2,549)$ & $(1,452)$ & $(1,028)$ & $(2,862)$ & $(-0,242)$ \\
\hline DY & $-0,005$ & $-0,002$ & 0,002 & $-0,001$ & 0,001 \\
& $(-4,294)$ & $(-1,569)$ & $(1,632)$ & $(-0,635)$ & $(1,281)$ \\
\hline DDCPI & $-0,003$ & 0,002 & $-0,002$ & $-0,001$ & 0,001 \\
& $(-3,059)$ & $(2,467)$ & $(-2,376)$ & $(-1,367)$ & $(0,720)$ \\
\hline DPM & $-0,006$ & 0,006 & 0,008 & $-0,007$ & $-0,003$ \\
& $(-1,637)$ & $(1,887)$ & $(2,354)$ & $(-1,991)$ & $(-0,781)$ \\
\hline DU & $-0,002$ & $-0,002$ & $-0,000$ & 0,000 & $-0,001$ \\
& $(-4,094)$ & $(-3,319)$ & $(-0,875)$ & $(0,263)$ & $(-1,079)$ \\
\hline
\end{tabular}

Oszacowania parametrów macierzy $\Pi$

\begin{tabular}{|lccccc|}
\hline & $W R$ & $Y$ & $D C P I$ & $P M$ & $U$ \\
\hline$D W R$ & $-0,115$ & $-0,036$ & $-1,319$ & 0,049 & $-0,221$ \\
& $(-1,425)$ & $(-0,328)$ & $(-2,841)$ & $(0,810)$ & $(-2,612)$ \\
\hline$D Y$ & 0,113 & $-0,193$ & $-0,590$ & 0,011 & $-0,020$ \\
& $(3,386)$ & $(-4,256)$ & $(-3,086)$ & $(0,457)$ & $(-0,568)$ \\
\hline$D D C P I$ & 0,009 & $-0,021$ & $-0,565$ & $-0,023$ & $-0,056$ \\
& $(0,353)$ & $(-0,645)$ & $(-4,059)$ & $(-1,275)$ & $(-2,190)$ \\
\hline$D P M$ & 0,085 & $-0,015$ & $-0,743$ & $-0,247$ & $-0,143$ \\
& $(0,862)$ & $(-0,113)$ & $(-1,319)$ & $(-3,345)$ & $(-1,389)$ \\
\hline$D U$ & 0,062 & $-0,110$ & $-0,223$ & 0,033 & $-0,033$ \\
& $(3,894)$ & $(-5,086)$ & $(-2,447)$ & $(2,780)$ & $(-1,992)$ \\
\hline
\end{tabular}

Próba:

Efektywna próba:

Liczba obserwacji - liczba zmiennych:

Zmienne:

Stała/Trend:

Liczba opóźnień:

Log-Likelihood $=1426,983$.
II kwartał 1995 - II kwartał 2011 r. (65 obserwacji) IV kwartał 1995 - II kwartał 2011 r. (63 obserwacje) 49 $W R, Y, D C P I, P M, U$ brak restrykcji 2

$D W R$ - przyrost przeciętnego wynagrodzenia w ujęciu realnym, $D Y$ - przyrost wydajności pracy, $D D C P I$ - przyrost przyrostu CPI (czyli inaczej przyrost stopy inflacji), DPM - przyrost wskaźnika cen transakcyjnych importu, $D U$ - przyrost stopy bezrobocia.

$\mathrm{W}$ nawiasach podano wartości statystyk $t$-Studenta.

Źródło: jak do tab. 4.3; obliczenia własne. 
Tabela A2. Statystyki dotyczące reszt w modelu z uwzględnieniem linii trendu

Tests for Autocorrelation

Ljung-Box(15): $\quad \chi^{2}(325)=591,464 \quad[0,000]$

$\operatorname{LM}(1): \quad \chi^{2}(25)=54,006 \quad[0,001]$

$\operatorname{LM}(2): \quad \chi^{2}(25)=38,850 \quad[0,038]$

Test for Normality: $\quad \chi^{2}(10)=11,440 \quad[0,324]$

Test for ARCH:

$\operatorname{LM}(1): \quad \chi^{2}(225)=202,245 \quad[0,860]$

$\operatorname{LM}(2): \quad \chi^{2}(450)=403,765 \quad[0,942]$

Statystyki jednowymiarowe

\begin{tabular}{lrrrrrr} 
& Mean & \multicolumn{6}{c}{ Std.Dev Skewness Kurtosis } & Maximum & Minimum \\
DWR & 0,000 & 0,012 & 0,201 & 3,595 & 0,034 & $-0,030$ \\
$D Y$ & $-0,000$ & 0,008 & 0,284 & 3,127 & 0,019 & $-0,020$ \\
$D D C P I$ & $-0,000$ & 0,005 & 0,236 & 3,225 & 0,014 & $-0,014$ \\
$D P M$ & 0,000 & 0,025 & 0,162 & 2,890 & 0,062 & $-0,054$ \\
$D U$ & $-0,000$ & 0,004 & $-0,789$ & 3,792 & 0,009 & $-0,013$
\end{tabular}

$\begin{array}{lccc} & \text { ARCH(2) } & \text { Normality } & \text { R-Squared } \\ D W R & 0,808[0,668] & 3,047[0,218] & 0,917 \\ D Y & 2,700[0,259] & 1,309[0,520] & 0,992 \\ D D C P I & 6,245[0,044] & 1,440[0,487] & 0,828 \\ D P M & 1,448[0,485] & 0,436[0,804] & 0,387 \\ D U & 2,821[0,244] & 6,708[0,035] & 0,811\end{array}$

W nawiasach kwadratowych podano wartości prawdopodobieństw testowych.

Źródło: jak do tab. 4.3; obliczenia własne. 
Wykres A1. Model VAR: reszty empiryczne w modelu z trendem

a) wydajność pracy

\section{DY}
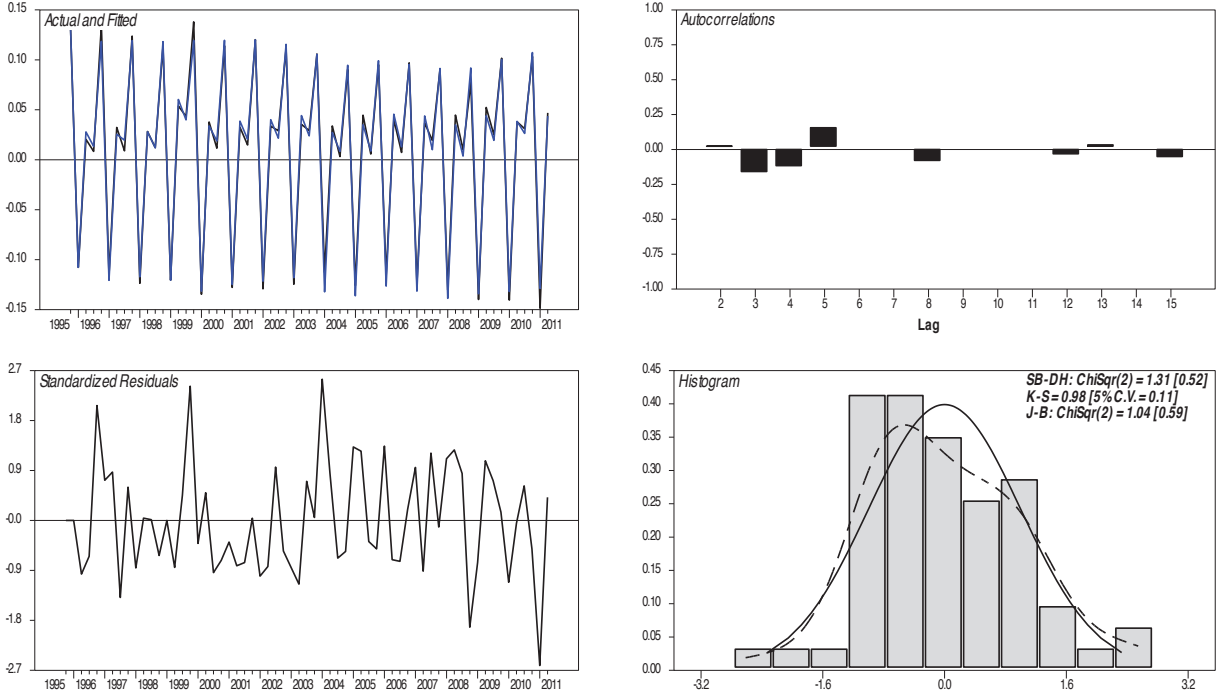

b) płace realne

\section{DWR}
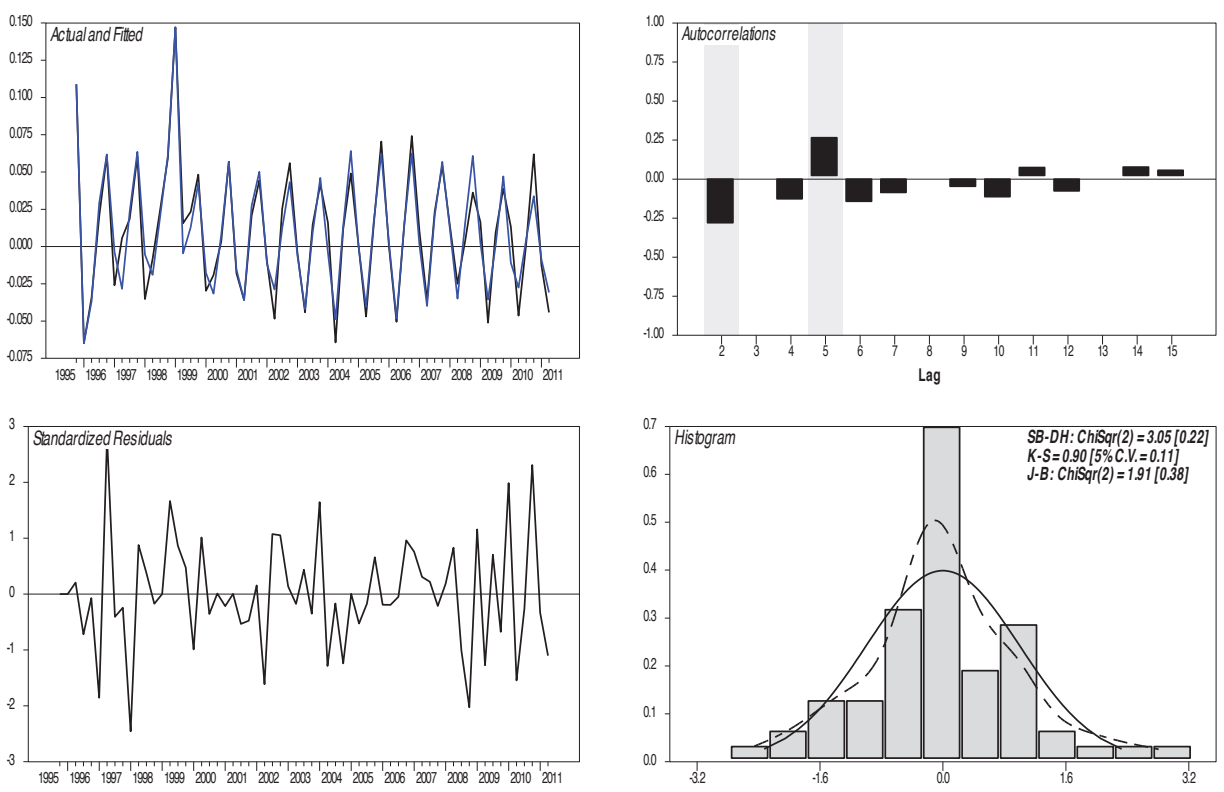
c) wskaźnik cen dóbr konsumpcyjnych (CPI)

\section{DDCPI}
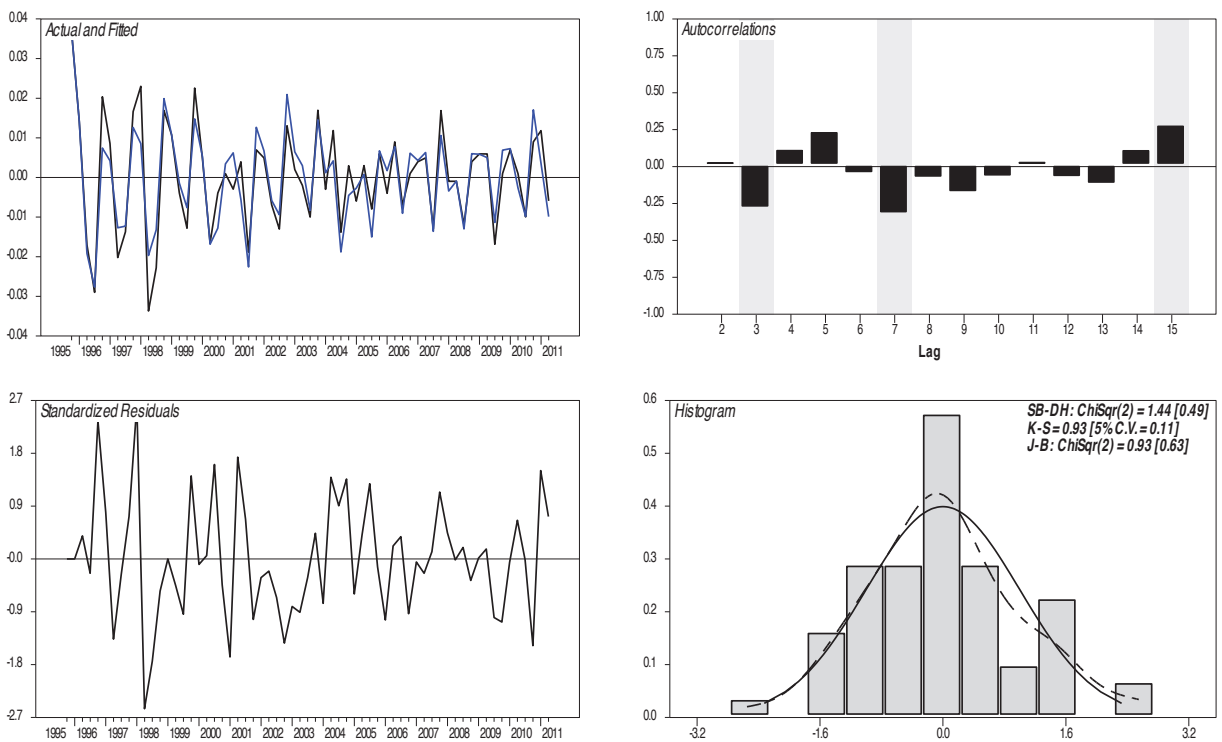

d) stopa bezrobocia

DU
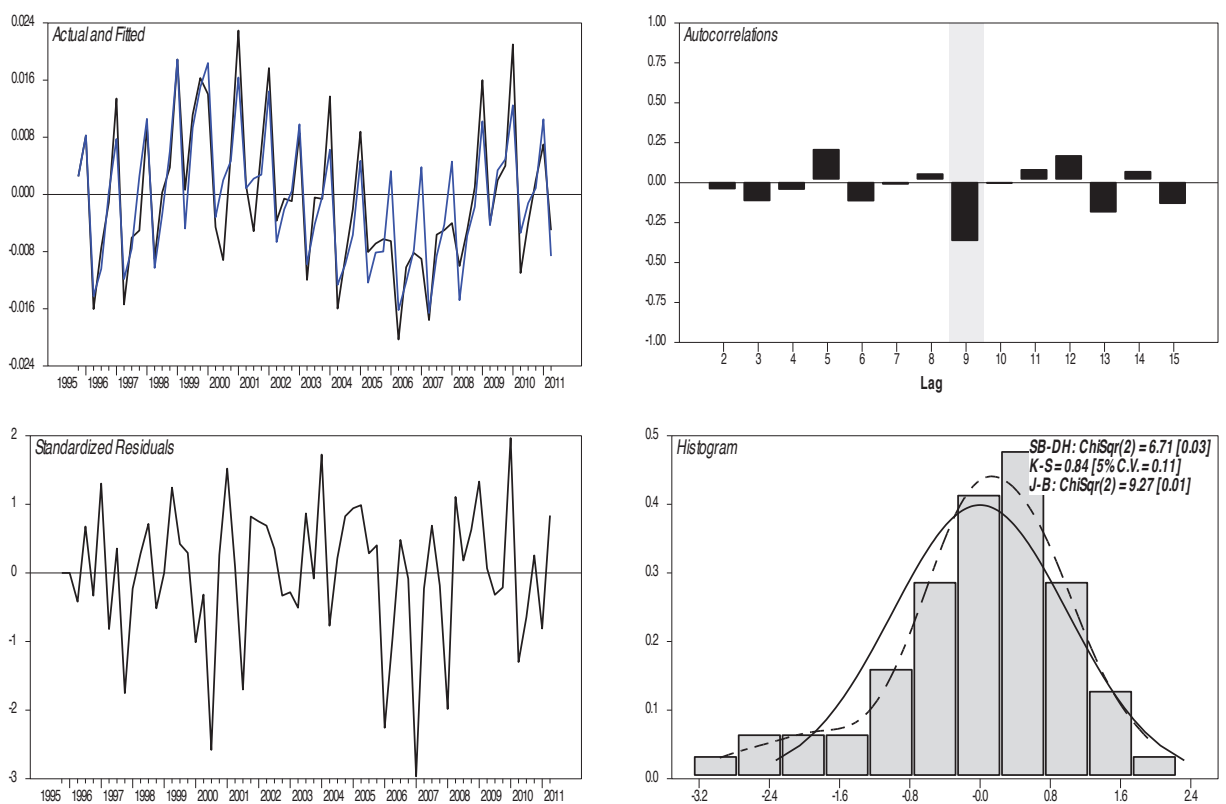
e) wskaźnik cen transakcyjnych importu

\section{DPM}
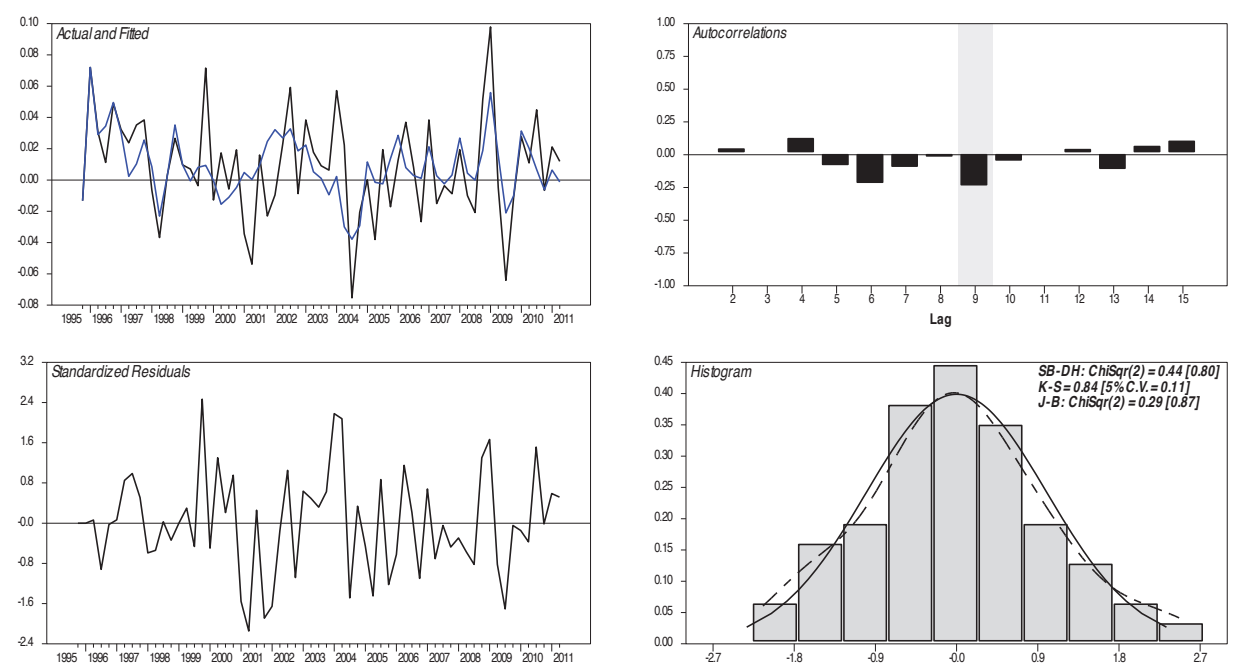

Źródło: jak do tab. 4.3; obliczenia własne. 
Tabela A3. Wyniki testu śladu oraz oszacowania macierzy towarzyszącej w modelu VAR ze zmiennymi zero-jedynkowymi

Wyniki testu śladu
\begin{tabular}{|c|c|c|c|c|c|c|}
\hline $\begin{array}{c}\text { Liczba wek- } \\
\text { torów koin- } \\
\text { tegrujących } \\
(r)\end{array}$ & $\begin{array}{c}\text { Wartość } \\
\text { własna } \\
\text { testu śladu }\end{array}$ & $\begin{array}{c}\text { Wartó́c } \\
\text { testu śladu }\end{array}$ & $\begin{array}{c}\text { Wartó́c } \\
95 \%\end{array}$ & $\begin{array}{c}\text { Prawdopo- } \\
\text { dobieństwo } \\
\text { testowe }\end{array}$ & $\begin{array}{c}\text { Prawdopo- } \\
\text { dobieństwo } \\
\text { testowe }\end{array}$ \\
\hline 1 & 0,610 & 121,375 & 102,488 & 88,554 & 0,000 & 0,003 \\
\hline 2 & 0,396 & 62,119 & 51,626 & 63,659 & 0,068 & 0,347 \\
\hline 3 & 0,253 & 30,404 & 22,836 & 42,770 & 0,484 & 0,880 \\
\hline 4 & 0,067 & 4,340 & 3,852 & 12,448 & 0,695 & 0,761 \\
\hline
\end{tabular}

Pierwiastki macierzy towarzyszącej

\begin{tabular}{|c|c|c|c|c|}
\cline { 2 - 5 } \multicolumn{1}{c|}{} & Real & Imaginary & Modulus & Argument \\
\hline Root1 & 0,980 & 0,000 & $\mathbf{0 , 9 8 0}$ & 0,000 \\
\hline Root2 & 0,910 & 0,158 & $\mathbf{0 , 9 2 4}$ & 0,171 \\
\hline Root3 & 0,910 & $-0,158$ & 0,924 & $-0,171$ \\
\hline Root4 & 0,715 & $-0,000$ & 0,715 & $-0,000$ \\
\hline Root5 & 0,179 & $-0,611$ & 0,636 & $-1,286$ \\
\hline Root6 & 0,179 & 0,611 & 0,636 & 1,286 \\
\hline Root7 & 0,270 & $-0,377$ & 0,464 & $-0,949$ \\
\hline Root8 & 0,270 & 0,377 & 0,464 & 0,949 \\
\hline Root9 & $-0,387$ & $-0,000$ & 0,387 & $-3,142$ \\
\hline Root10 & 0,278 & $-0,000$ & 0,278 & $-0,000$ \\
\hline
\end{tabular}

Źródło: jak do tab. 4.3; obliczenia własne. 
Tabela A4. Model VAR z trendem i zmiennymi zero-jedynkowymi - wyniki testu of exclusion i testu stacjonarności zmiennych

Wyniki testu wykluczeń
\begin{tabular}{|ccccccccc|}
\hline$R$ & $D G F$ & $5 \%$ C.V. & $W R$ & $Y$ & $D C P I$ & $P M$ & $U$ & TREND \\
\hline 1 & 1 & 3,841 & 17,768 & 20,302 & 18,623 & 9,746 & 2,522 & 10,231 \\
& & & {$[\mathbf{0 , 0 0 0 ]}$} & {$[\mathbf{0 , 0 0 0}]$} & {$[\mathbf{0 , 0 0 0}]$} & {$[\mathbf{0 , 0 0 2}]$} & {$[\mathbf{0 , 1 1 2}]$} & {$[\mathbf{0 , 0 0 1}]$} \\
\hline 2 & 2 & 5,991 & 29,145 & 33,442 & 24,150 & 10,041 & 8,083 & 17,353 \\
& & & {$[\mathbf{0 , 0 0 0 ]}$} & {$[\mathbf{0 , 0 0 0}]$} & $\mathbf{[ 0 , 0 0 0 ]}$ & {$[\mathbf{0 , 0 0 7 ]}$} & {$[\mathbf{0 , 0 1 8}]$} & {$[\mathbf{0 , 0 0 0}]$} \\
\hline 3 & \multirow{2}{*}{3} & 7,815 & 32,969 & 40,067 & 34,087 & 20,360 & 9,062 & 17,497 \\
& & & {$[0,000]$} & {$[0,000]$} & {$[0,000]$} & {$[0,000]$} & {$[0,028]$} & {$[0,001]$} \\
\hline 4 & 4 & 9,488 & 33,697 & 42,138 & 34,487 & 20,401 & 11,759 & 19,539 \\
& & & {$[0,000]$} & {$[0,000]$} & {$[0,000]$} & {$[0,000]$} & {$[0,019]$} & {$[0,001]$} \\
\hline
\end{tabular}

Test stacjonarności zmiennych

\begin{tabular}{|cccccccc|}
\hline$r$ & $D G F$ & $5 \%$ C.V. & $W R$ & $Y$ & $D C P I$ & $P M$ & $U$ \\
\hline 1 & \multirow{2}{*}{9,488} & 40,985 & 38,103 & 30,858 & 33,337 & 40,253 \\
& & & {$[\mathbf{0 , 0 0 0 ]}$} & {$[\mathbf{0 , 0 0 0}]$} & {$[\mathbf{0 , 0 0 0}]$} & {$[\mathbf{0 , 0 0 0}]$} & {$[\mathbf{0 , 0 0 0 ]}$} \\
\hline 2 & \multirow{2}{*}{3} & 7,815 & 14,774 & 10,822 & 6,915 & 7,603 & 13,317 \\
& & & {$[\mathbf{0 , 0 0 2}]$} & {$[\mathbf{0 , 0 1 3}]$} & {$[\mathbf{0 , 0 7 5 ]}$} & {$[\mathbf{0 , 0 5 5}]$} & {$[\mathbf{0 , 0 0 4}]$} \\
\hline 3 & \multirow{2}{*}{2} & 5,991 & 11,616 & 9,153 & 8,025 & 0,104 & 11,503 \\
& & & {$[0,003]$} & {$[0,010]$} & {$[0,018]$} & {$[0,949]$} & {$[0,003]$} \\
\hline 4 & \multirow{2}{*}{1} & \multirow{2}{*}{3,841} & 3,366 & 3,572 & 2,084 & 0,029 & 2,003 \\
& & & {$[0,067]$} & {$[0,059]$} & {$[0,149]$} & {$[0,866]$} & {$[0,157]$} \\
\hline
\end{tabular}

W nawiasach podano wartości prawdopodobieństw testowych.

Źródło: jak do tab. A3; obliczenia własne.

Tabela A5. Model VAR z trendem i zmiennymi zero-jedynkowymi - wyniki testu egzogeniczności zmiennych

\begin{tabular}{|cccccccc|}
\hline$r$ & $D G F$ & $5 \%$ C.V. & $W R$ & $Y$ & $D C P I$ & $P M$ & $U$ \\
\hline 1 & \multirow{2}{*}{3,841} & 2,494 & 18,375 & 7,068 & 0,405 & 12,693 \\
& & & {$[0,114]$} & {$[0,000]$} & {$[0,008]$} & {$[\mathbf{0 , 5 2 4}]$} & {$[0,000]$} \\
\hline 2 & 2 & 5,991 & 5,462 & 30,299 & 19,211 & 1,342 & 14,761 \\
& & & {$[0,065]$} & {$[0,000]$} & {$[0,000]$} & {$[\mathbf{0 , 5 1 1}]$} & {$[0,001]$} \\
\hline 3 & \multirow{2}{*}{3} & 7,815 & 8,146 & 33,871 & 29,099 & 11,748 & 16,183 \\
& & & {$[0,043]$} & {$[0,000]$} & {$[0,000]$} & {$[0,008]$} & {$[0,001]$} \\
\hline 4 & \multirow{2}{*}{4} & 9,488 & 8,473 & 36,531 & 31,452 & 13,205 & 19,511 \\
& & & {$[0,076]$} & {$[0,000]$} & {$[0,000]$} & {$[0,010]$} & {$[0,001]$} \\
\hline
\end{tabular}

W nawiasach podano wartości prawdopodobieństw testowych.

Źródło: jak do tab. A3; obliczenia własne. 
Tabela A6. Model VAR bez zmiennych zero-jedynkowych: wyniki testów

Test śladu
\begin{tabular}{|c|c|c|c|c|c|c|}
\hline $\begin{array}{c}\text { Liczba } \\
\text { wektorów } \\
\text { kointegrujących } \\
(r)\end{array}$ & Wartość własna & $\begin{array}{c}\text { Wartość testu } \\
\text { śladu }\end{array}$ & $\begin{array}{c}\text { Wartość testu } \\
\text { śladu }\end{array}$ & $95 \%$ & $\begin{array}{c}\text { Prawdopo- } \\
\text { dobieństwo } \\
\text { testowe }\end{array}$ & $\begin{array}{c}\text { Prawdopo- } \\
\text { dobieństwo } \\
\text { testowe }\end{array}$ \\
\hline 0 & 0,599 & 119,570 & 101,407 & 88,554 & 0,000 & 0,004 \\
\hline 1 & 0,341 & 61,995 & 52,147 & 63,659 & 0,069 & 0,326 \\
\hline 2 & 0,222 & 35,735 & 28,021 & 42,770 & 0,219 & 0,625 \\
\hline 3 & 0,192 & 19,902 & 16,735 & 25,731 & 0,235 & 0,443 \\
\hline 4 & 0,098 & 6,474 & 3,251 & 12,448 & 0,413 & 0,837 \\
\hline
\end{tabular}

Pierwiastki macierzy towarzyszącej

\begin{tabular}{|c|c|c|c|c|}
\cline { 2 - 5 } \multicolumn{1}{c|}{} & Real & Imaginary & Modulus & Argument \\
\hline Root1 & 0,971 & $-0,000$ & $\mathbf{0 , 9 7 1}$ & $-0,000$ \\
\hline Root2 & 0,909 & $-0,177$ & $\mathbf{0 , 9 2 6}$ & $-0,192$ \\
\hline Root3 & 0,909 & 0,177 & $\mathbf{0 , 9 2 6}$ & 0,192 \\
\hline Root4 & 0,635 & $-0,000$ & 0,635 & $-0,000$ \\
\hline Root5 & 0,207 & 0,558 & 0,595 & 1,216 \\
\hline Root6 & 0,207 & $-0,558$ & 0,595 & $-1,216$ \\
\hline Root7 & 0,164 & 0,396 & 0,428 & 1,178 \\
\hline Root8 & 0,164 & $-0,396$ & 0,428 & $-1,178$ \\
\hline Root9 & $-0,413$ & 0,000 & 0,413 & 3,142 \\
\hline Root10 & 0,312 & $-0,000$ & 0,312 & $-0,000$ \\
\hline
\end{tabular}

Wyniki testu wykluczeń

\begin{tabular}{|ccccccccc|}
\hline$r$ & $D G F$ & $5 \%$ C.V. & $W R$ & $Y$ & $D C P I$ & $P M$ & $U$ & TREND \\
\hline 1 & 1 & 3,841 & 17,938 & 25,485 & 18,123 & 3,273 & 3,986 & 17,521 \\
& & & {$[0,000]$} & {$[0,000]$} & {$[0,000]$} & {$[0,070]$} & {$[0,046]$} & {$[0,000]$} \\
\hline 2 & 2 & 5,991 & 28,162 & 35,272 & 27,207 & 7,270 & 8,274 & 19,375 \\
& & & {$[0,000]$} & {$[0,000]$} & {$[0,000]$} & {$[0,026]$} & {$[0,016]$} & {$[0,000]$} \\
\hline 3 & 3 & 7,815 & 29,070 & 36,766 & 29,587 & 9,268 & 9,514 & 20,323 \\
& & & {$[0,000]$} & {$[0,000]$} & {$[0,000]$} & {$[0,026]$} & {$[0,023]$} & {$[0,000]$} \\
\hline 4 & 4 & 9,488 & 31,501 & 42,596 & 36,295 & 13,391 & 13,464 & 23,507 \\
& & & {$[0,000]$} & {$[0,000]$} & {$[0,000]$} & {$[0,010]$} & {$[0,009]$} & {$[0,000]$} \\
\hline
\end{tabular}




\begin{tabular}{|c|c|c|c|c|c|c|c|}
\hline \multicolumn{8}{|c|}{ Test stacjonarności zmiennych } \\
\hline$r$ & $D G F$ & $5 \%$ C.V. & $W R$ & Y & $D C P I$ & $P M$ & $U$ \\
\hline \multirow[t]{2}{*}{1} & 4 & 9,488 & 43,505 & 42,186 & 42,924 & 41,462 & 43,076 \\
\hline & & & {$[0,000]$} & {$[0,000]$} & {$[0,000]$} & {$[0,000]$} & {$[0,000]$} \\
\hline \multirow[t]{2}{*}{2} & 3 & 7,815 & 12,468 & 12,140 & 11,627 & 10,583 & 12,397 \\
\hline & & & {$[0,006]$} & {$[0,007]$} & {$[0,009]$} & {$[0,014]$} & {$[0,006]$} \\
\hline \multirow[t]{2}{*}{3} & 2 & 5,991 & 2,056 & 1,730 & 1,744 & 0,947 & 2,046 \\
\hline & & & {$[0,358]$} & {$[0,421]$} & {$[0,418]$} & {$[0,623]$} & {$[0,360]$} \\
\hline \multirow[t]{2}{*}{4} & 1 & 3,841 & 0,349 & 0,034 & 0,000 & 0,176 & 0,027 \\
\hline & & & {$[0,555]$} & {$[0,854]$} & {$[0,995]$} & {$[0,675]$} & {$[0,868]$} \\
\hline \multicolumn{8}{|c|}{ Test egzogeniczności zmiennych } \\
\hline$r$ & $D G F$ & $5 \%$ C.V. & $W R$ & Y & $D C P I$ & $P M$ & $U$ \\
\hline \multirow[t]{2}{*}{1} & 1 & 3,841 & 0,717 & 26,371 & 6,006 & 1,944 & 11,257 \\
\hline & & & {$[0,397]$} & {$[0,000]$} & {$[0,014]$} & {$[0,163]$} & {$[0,001]$} \\
\hline \multirow[t]{2}{*}{2} & 2 & 5,991 & 3,806 & 30,238 & 10,155 & 3,535 & 13,219 \\
\hline & & & {$[0,149]$} & {$[0,000]$} & {$[0,006]$} & {$[0,171]$} & {$[0,001]$} \\
\hline \multirow[t]{2}{*}{3} & 3 & 7,815 & 3,920 & 32,591 & 10,373 & 5,934 & 15,055 \\
\hline & & & {$[0,270]$} & {$[0,000]$} & {$[0,016]$} & {$[0,115]$} & {$[0,002]$} \\
\hline \multirow[t]{2}{*}{4} & 4 & 9,488 & 10,314 & 36,664 & 17,125 & 8,688 & 19,104 \\
\hline & & & {$[0,035]$} & {$[0,000]$} & {$[0,002]$} & {$[0,069]$} & {$[0,001]$} \\
\hline
\end{tabular}

W nawiasach podano wartości prawdopodobieństw testowych.

Źródło: jak do tab. A3; obliczenia własne. 
Wykres A2. Model VAR: wektory kointegrujące w modelu przed nałożeniem restrykcji

a) pierwszy wektor

Beta1'z' $1(t)$

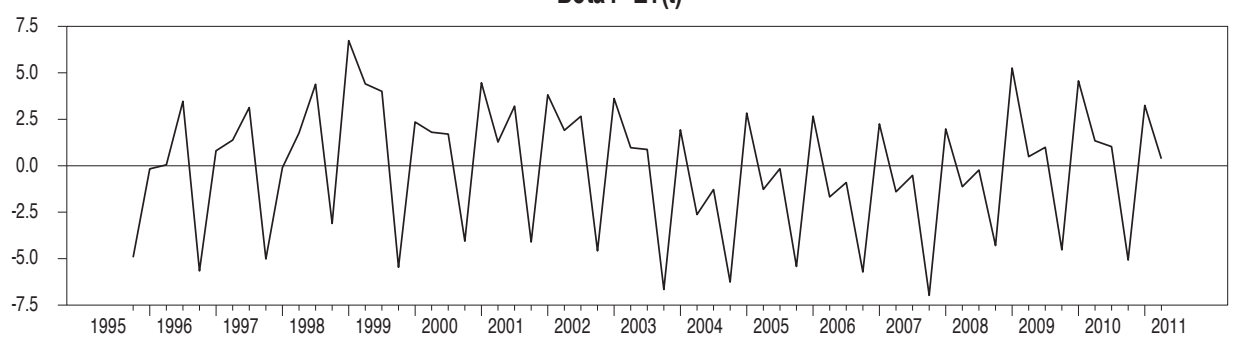

Beta1'R1(t)

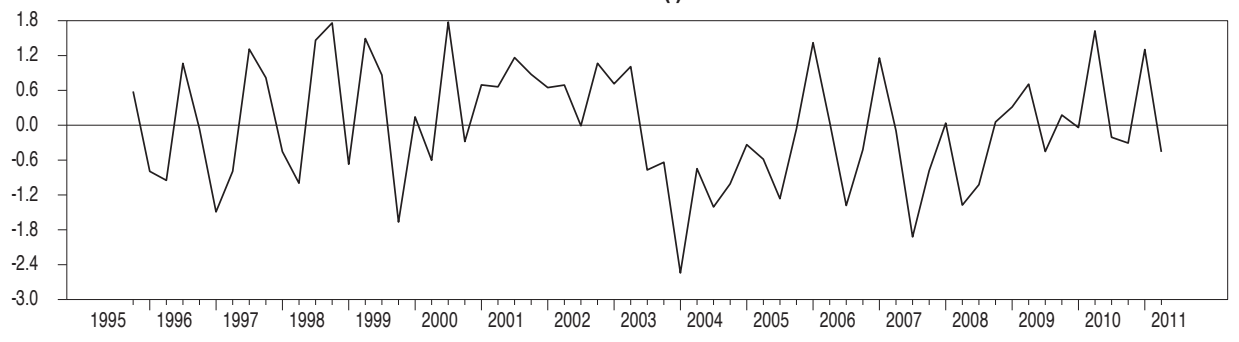

b) drugi wektor

Beta2*Z1(t)

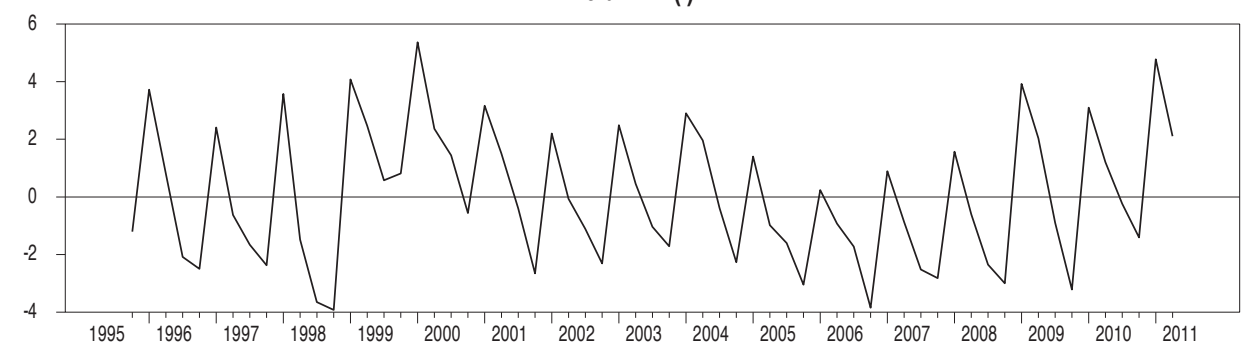

Beta2"R1(t)

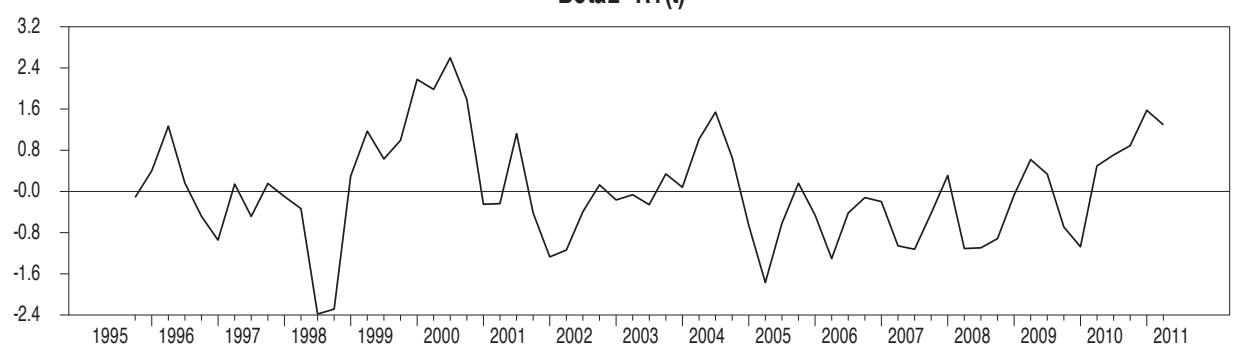


c) trzeci wektor

Beta3"Z1 (t)

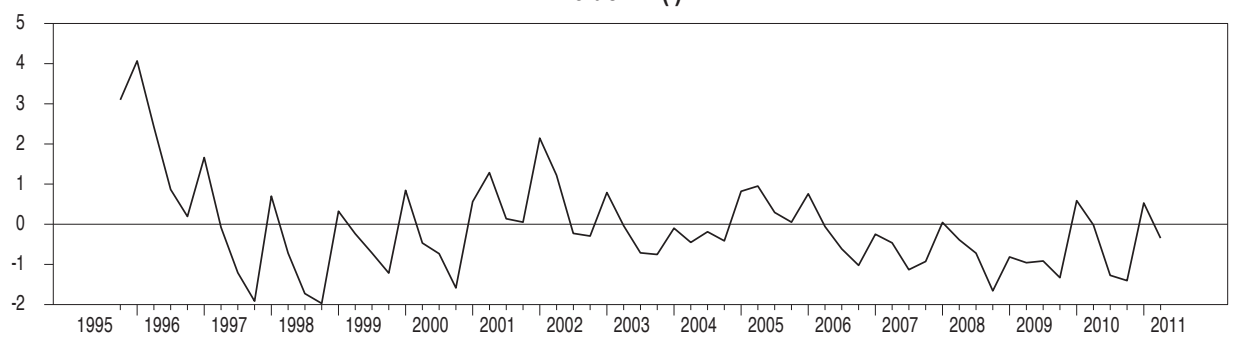

Beta3'*R1(t)

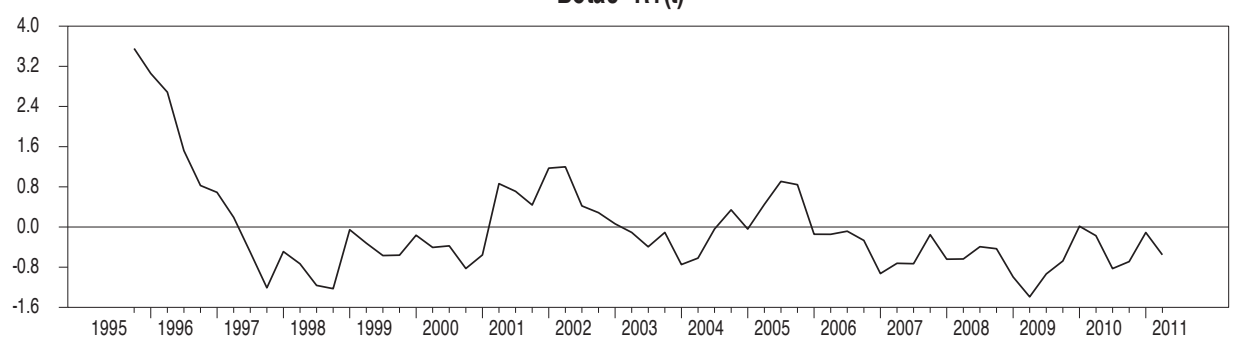

d) czwarty wektor

Beta4'*21(t)

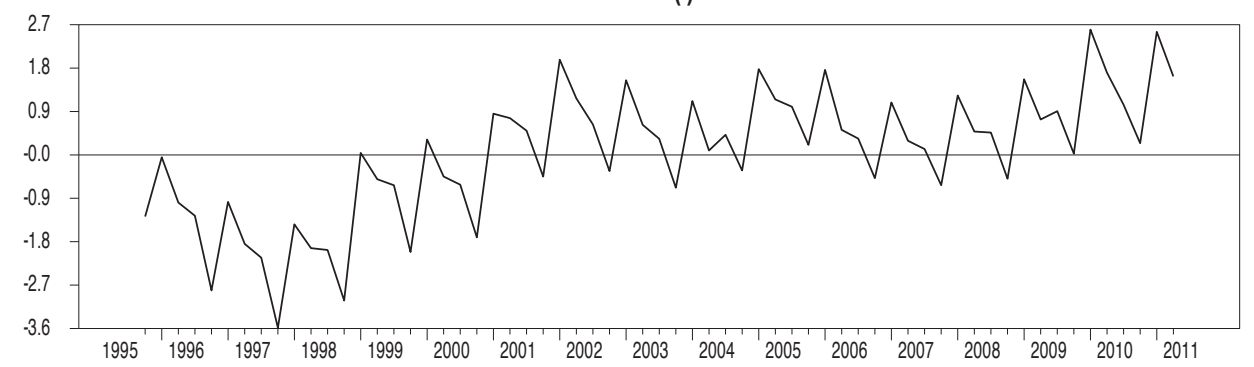

\section{Beta4'R1(t)}

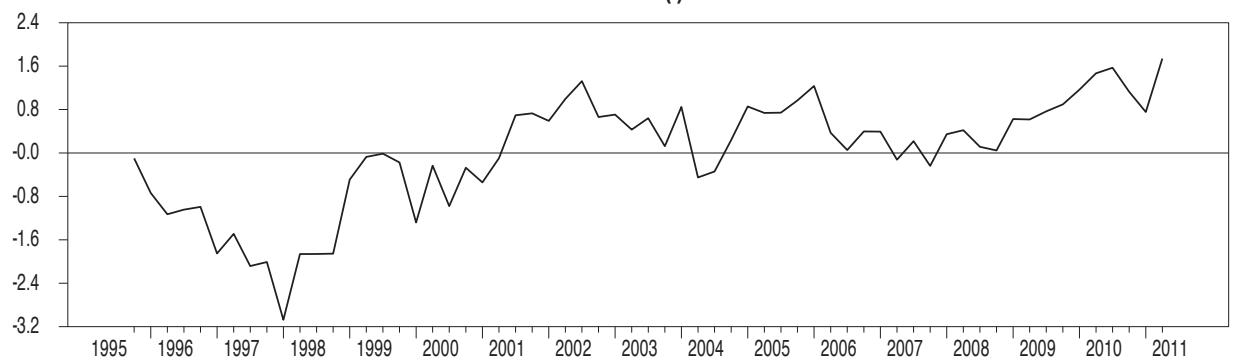


e) piąty wektor

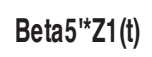

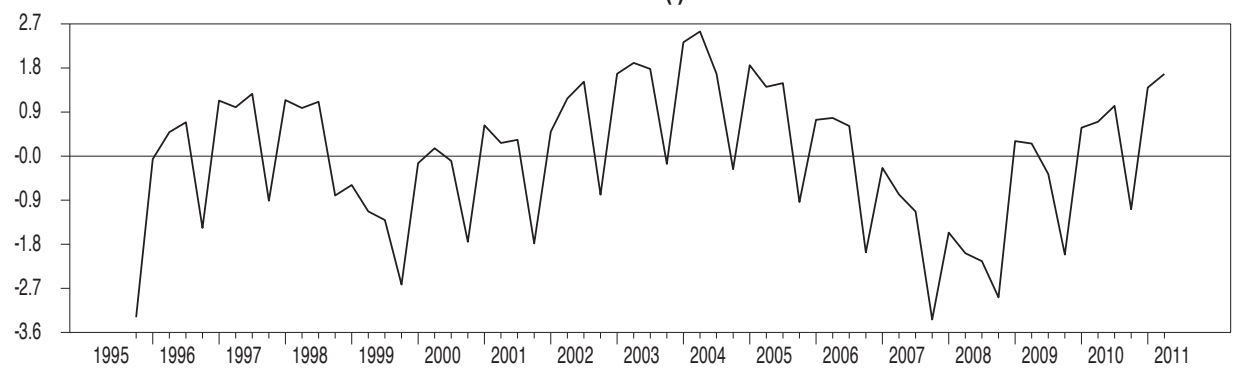

Beta5"R1(t)

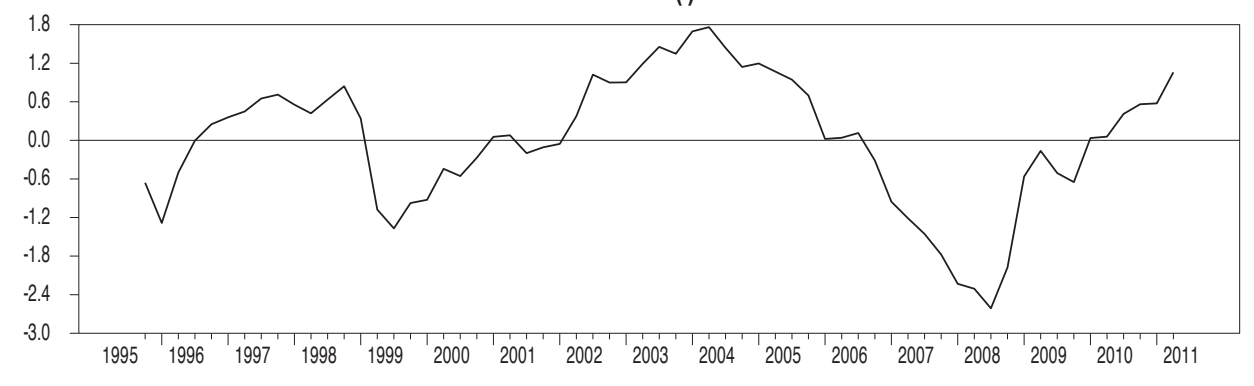

Źródło: jak do tab. A3; obliczenia własne. 
Wykres A3. Model VAR: wektory kointegrujące z nałożonymi restrykcjami

a) pierwszy wektor

\section{Beta1'z21(t)}

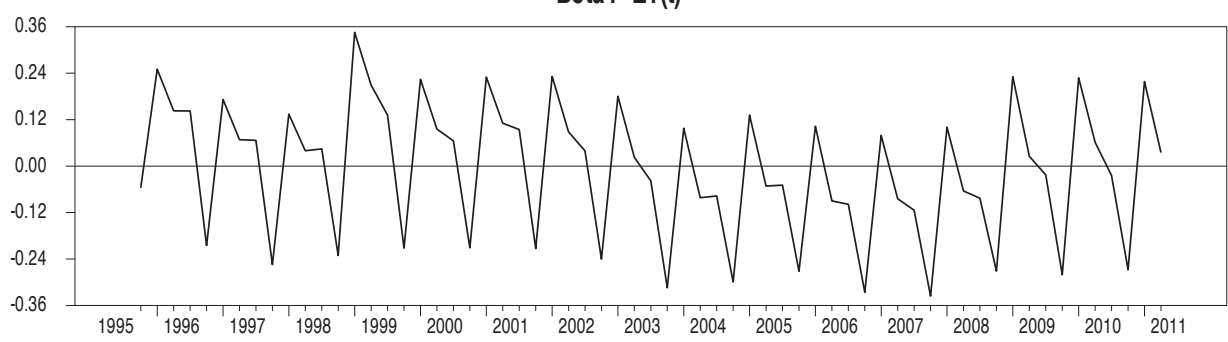

Beta1'*R1(t)

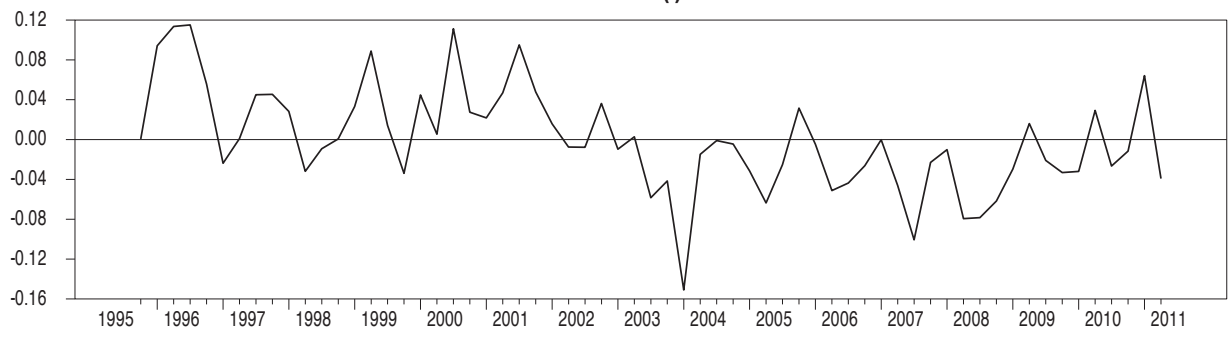

b) drugi wektor

Beta2'Z1 (t)

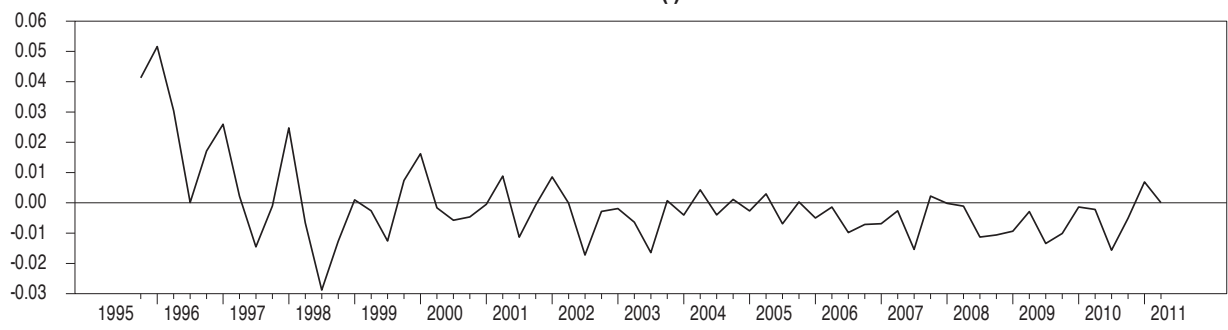

Beta2'R1(t)

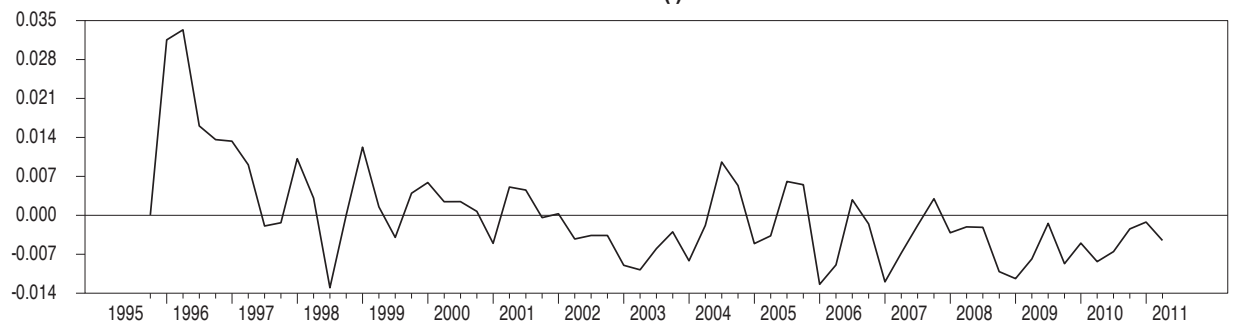

Źródło: jak do tab. A3; obliczenia własne. 



\section{Rozdział 5}

\section{Bezrobocie równowagi a polityka makroekonomiczna w Polsce}

\subsection{Wprowadzenie}

$\mathrm{Z}$ analiz przeprowadzonych w rozdziale pierwszym wynika, że poziom bezrobocia równowagi zależy do czynników realnych, a zatem ani polityka fiskalna, ani polityka pieniężna nie powinny wpływać bezpośrednio na jego poziom. Jednakże w krótkim okresie polityka fiskalna i pieniężna mogą wpływać na poziom faktycznego bezrobocia. Skuteczność obu polityk jako narzędzi ograniczania bezrobocia zależy m.in. od relacji między faktyczną stopą bezrobocia i stopą bezrobocia $\mathrm{w}$ równowadze. Im mniejsza jest różnica między faktyczną stopą bezrobocia a stopą bezrobocia w równowadze, tym mniejsza jest skuteczność polityki fiskalnej i pieniężnej w kształtowaniu bezrobocia.

Celem tego rozdziału jest zbadanie, czy relacja między faktyczną stopą bezrobocia a stopą bezrobocia równowagi wpływała na zmiany charakteru prowadzonej polityki fiskalnej i polityki pieniężnej w Polsce w latach 1995-2011.

W analizach empirycznych wykorzystano syntetyczne wskaźniki oceny stopnia restrykcyjności polityki fiskalnej i pieniężnej.

\subsection{Polityka pieniężna a bezrobocie równowagi}

\subsubsection{Pojęcie i miary restrykcyjności polityki pieniężnej ${ }^{1}$}

Polityka pieniężna polega na kształtowaniu wielkości podaży pieniądza w gospodarce przez bank centralny. Obecnie przyjmuje się, że jej podstawowym celem jest zapewnienie stabilności cen, co stanowi podstawę długofalowego wzrostu gospodarczego ${ }^{2}$.

\footnotetext{
${ }^{1}$ Ten podrozdział powstał na podstawie opracowania: Kucharski (2012).

${ }^{2}$ Polityka pieniężna w Polsce realizowana jest przez Narodowy Bank Polski. Zgodnie z art. 227 par. 1 Konstytucji RP Narodowy Bank Polski odpowiada za wartość polskiego pieniądza.
} 
Do podstawowych narzędzi polityki monetarnej zalicza się przede wszystkim stopy procentowe banku centralnego, do których należą: stopa rezerw obowiązkowych, stopa redyskontowa, stopa referencyjna oraz operacje otwartego rynku3

Głównymi tradycyjnymi kanałami mechanizmu transmisji polityki pieniężnej są kanał stopy procentowej, kanał kursu walutowego oraz kanały kredytowe. Wzrost podaży pieniądza prowadzi do spadku rynkowej stopy procentowej, który prowadzi z kolei do wzrostu inwestycji i wzrostu dochodu narodowego.

Kanał kursu walutowego stanowi rozszerzenie kanału stopy procentowej. Spadek rynkowej stopy procentowej spowodowany zwiększeniem podaży pieniądza prowadzi do spadku (deprecjacji) kursu walutowego. Spadek kursu walutowego (definiowanego jako cena waluty krajowej wyrażonej w walutach) obcych skutkuje wzrostem eksportu i spadkiem importu oraz wzrostem salda bilansu handlowego. Wzrost salda bilansu handlowego prowadzi do wzrostu agregatowego popytu i w konsekwencji do wzrostu produkcji, wzrostu zatrudnienia i spadku bezrobocia. Spadek kursu walutowego może również prowadzić do wzrostu inflacji.

Trzeci kanał transmisji stanowi rozszerzenie kanału stóp procentowych. Wzrost podaży pieniądza w gospodarce prowadzi do wzrostu kwoty udzielanych kredytów. W efekcie wzrostu wolumenu kredytów następuje wzrost inwestycji i dochodu narodowego.

Poglądy na temat celów polityki pieniężnej były przedmiotem wielu sporów i dyskusji przedstawicieli głównych nurtów ekonomii. Do czasu rewolucji keynesowskiej w debatach ekonomicznych dominował pogląd o neutralności pieniądza wysunięty przez I. Fishera w 1911 r. Neutralność pieniądza oznacza, że zmiany jego ilości w obiegu wpływają jedynie na zmiany ogólnego poziomu cen w gospodarce, nie wpływają natomiast na wielkości realne, takie jak produkcja i zatrudnienie. Fisher w swojej teorii zakłada, że szybkość obiegu pieniądza i łączna wartość sprzedanych produktów są stałe, zatem zmiany cen są rosnącą funkcją zmiany ilości pieniądza w obiegu. Pomimo pewnych modyfikacji ilościowej teorii pieniądza neoklasycy podtrzymywali tezę o neutralności pieniądza (zob. Kaźmierczak 2008, s. 84-86).

Największe zmiany do ilościowej teorii pieniądza wprowadził M. Friedman - czołowy przedstawiciel monetaryzmu. Stworzył on w zasadzie nową wersję tej koncepcji. Według niego popyt na pieniądz i podaż pieniądza są wielkościami niezależnymi od siebie. Podaż pieniądza jest wielkością egzogeniczną, zaś inflacja jest spowodowana nadmierną ilością pieniądza w obiegu.

W ustawie z 29 sierpnia 1997 r. o Narodowym Banku Polskim w art. 3 zapisano, że podstawowym celem działalności NBP jest utrzymanie stabilnego poziomu cen, przy jednoczesnym wspieraniu polityki gospodarczej Rządu, o ile jednak nie ogranicza to realizacji podstawowego celu NBP.

${ }^{3}$ Oprócz tradycyjnych kanałów transmisji w literaturze ekonomicznej wymienia się kanał kosztowy oraz kanał podejmowanego ryzyka (zob. Demchuk, Łyziak, Przystupa, Sznajderska, Wróbel 2012, s. 11). 
Zdaniem Friedmana zwiększenie podaży pieniądza w długim okresie nie wpływa na produkcję i zatrudnienie, powoduje natomiast wzrost poziomu cen. W okresie długim bezrobocie ustala się na poziomie naturalnej stopy bezrobocia, czyli występującej w warunkach równowagi na rynku pracy. Jest ona niewrażliwa na politykę makroekonomiczną państwa. Monetaryści dopuszczają możliwość pozytywnego wpływu zwiększenia podaży pieniądza na produkcję w okresie krótkim i średnim. Jednakże wzrost produkcji będzie miał charakter nietrwały.

Bardziej radykalne wnioski odnośnie oddziaływania polityki pieniężnej na zatrudnienie i bezrobocie wysuwają przedstawiciele nowej makroekonomii klasycznej. Stoją oni na stanowisku, że zmiany wielkości pieniężnych nie powodują nawet przejściowych odchyleń stopy bezrobocia od poziomu naturalnego, za wyjątkiem sytuacji, gdy nie są one antycypowane przez podmioty gospodarcze. Krzywa Philipsa, według nowych klasyków, jest pionową linią prostą zarówno w krótkim, jak i długim okresie.

Większość ekonomistów jest obecnie zgodna, że pieniądz jest neutralny w okresie długim (zob. Wojtyna 2004, s. 5; Solow 2002, s. 17-18; Taylor 2002, s. 41-42). Przekonanie to jest częścią konsensusu określanego mianem nowej syntezy neoklasycznej. W dalszym ciągu przedmiotem sporów są natomiast krótkookresowe skutki polityki pieniężnej.

W ostatnich latach, w obliczu światowego kryzysu finansowego, można zauważyć, że więcej zwolenników ma hipoteza o braku neutralności pieniądza w okresie krótkim. Daje to bankom centralnym krajów dotkniętych kryzysem możliwość wykorzystania polityki monetarnej w celu poprawy koniunktury gospodarczej. Są jednak obawy, że w dłuższej perspektywie taka polityka doprowadzi do wzrostu inflacji.

Oddziaływanie polityki pieniężnej na rynek pracy może odbywać się poprzez zmiany poziomu rynkowej stopy procentowej. Obniżenie stóp procentowych banku centralnego prowadzi w konsekwencji do spadku rynkowych stóp procentowych, który zazwyczaj powoduje wzrost inwestycji, co w konsekwencji skutkuje wzrostem agregatowego popytu, wzrostem produkcji, wzrostem zatrudnienia i spadkiem bezrobocia.

Mając to na względzie, w niniejszej pracy i w tym podrozdziale zostanie podjęta próba odpowiedzi na pytanie, czy występował związek między relacją poziomu bezrobocia równowagi i faktycznej stopy bezrobocia a stopniem restrykcyjności polityki pieniężnej w Polsce. Spróbuję odpowiedzieć na to pytanie, biorąc pod uwagę dane z okresu I kwartał 1997 - II kwartał 2011 r.

Jak wspomniano w rozdziale pierwszym, poziom szeroko rozumianego bezrobocia równowagi zależy od wielu czynników. Trudno jest również określić, który z tych czynników ma decydujące znaczenie w danym okresie. W zależności od zastosowanej metody i zestawu danych statystycznych oszacowania stóp bezrobocia równowagi różnią się między sobą (niekiedy dosyć znacznie). Dlatego 
też trudno zakładać, że banki centralne będą dokonywać automatycznych zmian stopnia restrykcyjności polityki pieniężnej w zależności od zmiany relacji między rzeczywistą stopą bezrobocia a stopą bezrobocia równowagi.

Pomimo tych zastrzeżeń, relacja między faktyczną stopą bezrobocia a stopą bezrobocia równowagi stanowi dla banku centralnego ważny punkt odniesienia przy prowadzonej polityce pieniężnej (zob. Gradzewicz 2011, s. 90). Określa ona bowiem kierunek zmian stóp procentowych niezbędny dla przywrócenia stanu równowagi. Spadek faktycznej stopy bezrobocia poniżej stopy bezrobocia równowagi może być sygnałem do zaostrzenia polityki pieniężnej. Natomiast wzrost faktycznej stopy bezrobocia powyżej stopy bezrobocia równowagi może wskazywać na konieczność zmniejszenia stopnia restrykcyjności polityki pieniężnej.

Zmiany relacji między faktyczną stopą bezrobocia a stopą bezrobocia równowagi informują bowiem o poziomie napięć płacowych na rynku pracy oraz ich ewentualnym wpływie na inflację. Jeśli faktyczna stopa bezrobocia jest wyższa od szeroko rozumianej stopy bezrobocia równowagi, to wówczas presja na wzrost płac ulega osłabieniu, ponieważ mamy wówczas do czynienia z pogorszeniem koniunktury gospodarczej. Osłabienie presji płacowej stwarza zatem możliwość złagodzenia polityki pieniężnej4. W przeciwnym razie, gdy faktyczna stopa bezrobocia jest niższa od bezrobocia równowagi, następuje wzrost presji płacowej i w konsekwencji może to skłonić bank centralny do zastosowania restrykcyjnej polityki pieniężnej.

Jednym ze sposobów oceny stopnia restrykcyjności polityki pieniężnej jest analiza zmian poziomu realnych stop procentowych, podaży pieniądza lub realnego kursu walutowego. Jednakże analiza zmian tych wielkości może nie dawać jednoznacznej odpowiedzi co do poziomu restrykcyjności tej polityki. W systemie kursów płynnych zmiany realnego kursu walutowego mogą być rezultatem ataków spekulacyjnych. Na podstawie zmiany ich poziomu nie można więc jednoznacznie określić stopnia restrykcyjności polityki pieniężnej. Opieranie się na zmianach podaży pieniądza lub realnych stóp procentowych może także prowadzić do błędnych wniosków co do stopnia restrykcyjności polityki pieniężnej.

Bardziej precyzyjnym narzędziem służącym do oceny stopnia restrykcyjności polityki pieniężnej jest indeks MCI (Monetary Condition Index). Został on skonstruowany w drugiej połowie lat 80 . XX w. (zob. Kot 2003a, s. 60). Szczególnie zainteresowane wykorzystaniem tego wskaźnika były banki centralne stosujące strategię bezpośredniego celu inflacyjnego.

Indeks $M C I$, jako narzędzie pomiaru restrykcyjności polityki pieniężnej, ma zarówno zwolenników, jak i zagorzałych krytyków. Według zwolenników jego

\footnotetext{
${ }^{4}$ Oczywiście przy założeniu, że główny cel - czyli stabilizacja cen - nie jest zagrożony. Trzeba bowiem pamiętać, że na inflację wpływa jednocześnie wiele czynników.
} 
zaletą w prowadzeniu polityki pieniężnej jest to, że uwzględnia on zmiany kursu walutowego, które w przypadku małych gospodarek otwartych stanowią bardzo istotny kanał transmisji impulsów polityki pieniężnej. Krytycy tego podejścia wskazują, że należałoby wobec tego w konstrukcji indeksu uwzględnić wszystkie kanały transmisji impulsów polityki pieniężnej (zob. np. Stevens 1998, s. 36). Ponadto, różne źródła szoków wpływających na poziom kursu walutowego, takie jak np. pogorszenie terms of trade i zmiany światowych stóp procentowych wymagają zupełnie odmiennych reakcji ze strony polityki pieniężnej, a tego nie uwzględnia indeks $M C I$ (zob. Urbańska 2002, s. 14).

Pomimo tych zastrzeżeń, zdecydowano się na wykorzystanie indeksu MCI jako miernika stopnia restrykcyjności polityki pieniężnej. Można go opisać wzorem:

$$
M C I_{t}=\alpha_{1}\left(r_{t}-r_{0}\right)+\alpha_{2}\left(q_{t}-q_{0}\right)
$$

gdzie:

$r_{t}-$ realna stopa procentowa w okresie $t$,

$r_{0}$ - realna stopa procentowa w okresie bazowym,

$q_{t}$ - logarytm realnego kursu walutowego w okresie $t$,

$q_{0}$ - logarytm realnego kursu walutowego w okresie bazowym.

$\mathrm{Z}$ równania (5.1) wynika, że indeks $M C I$ to średnia ważona zmian realnego kursu walutowego i zmian stopy procentowej względem okresu bazowego. Taka postać indeksu restrykcyjności polityki pieniężnej oznacza, że w gospodarce otwartej zmiany w polityce pieniężnej znajdują najszybszy wpływ na gospodarkę poprzez kanały stopy procentowej oraz kursu walutowego.

W literaturze można znaleźć zmodyfikowany wskaźnik $M C I$ następującej postaci:

$$
M C I_{t}=\alpha_{1}\left(r_{t}-r_{0}\right)+\alpha_{2}\left(\Delta q_{t}-\Delta q_{0}\right)
$$

gdzie:

$\Delta q_{t}$ - zmiana dynamiki lub przyrost realnego kursu walutowego względem okresu bazowego zazwyczaj w ciągu 1 roku.

Według A. Kota (2003a) wyznaczanie MCI przy wykorzystaniu równania (5.2) może prowadzić do przekłamań i nieporozumień odnośnie stopnia restrykcyjności polityki monetarnej. Przy interpretacji $M C I$ zasadnicze znaczenie ma kierunek jego zmian, a nie wartość bezwzględna indeksu. Oprócz $M C I$ wyrażanego w kategoriach realnych w literaturze znaleźć można indeks $M C I$ w ujęciu nominalnym. Jest on wyznaczany w oparciu o średnią ważoną nominalnych stóp procentowych oraz nominalnego kursu walutowego. 
Wartości parametrów $\alpha_{1}$ oraz $\alpha_{2}$ w przedstawionych równaniach (5.1)-(5.2) są wykorzystywane do oceny stopnia otwartości gospodarki. W tym celu oblicza się MCI_ratio (zob. Kot 2003a, s. 22):

$$
M C I \_ \text {ratio }=\frac{\alpha_{1}}{\alpha_{2}}
$$

Wskaźnik MCI_ratio informuje, o ile procent zmieni się realny kurs walutowy na skutek zmiany realnej stopy procentowej o 1 punkt procentowy, w kontekście wpływu na aktywność gospodarczą i inflację. Im wyższa jest wysokość MCI_ratio, tym bardziej zamknięta jest dana gospodarka.

Podstawowe znaczenie dla oszacowania indeksu MCI ma odpowiednie ustalenie wartości parametrów $\alpha_{1}$ oraz $\alpha_{2}$. Zazwyczaj ich wysokość szacowana jest przy wykorzystaniu dużych modeli makroekonomicznych (strukturalnych lub modeli VAR (wektorowo-autoregresyjnych)) oraz na podstawie krzywej IS lub krzywej Phillipsa. Jednym ze sposobów wyznaczania wartości współczynnika $\alpha_{2}$ (stojącym przy kursie walutowym) jest ustalenie go na poziomie równym udziałowi wymiany zagranicznej kraju w PKB.

\subsubsection{Charakter polityki pieniężnej a tendencje zmian bezrobocia równowagi w latach 1997-2011}

Przejdźmy zatem do analizy charakteru polityki pieniężnej w Polsce w badanym okresie. Na wykresie 5.1 przedstawiono dane o poziomie realnych stóp procentowych i realnego efektywnego kursu walutowego w Polsce w okresie I kwartał 1997 - II kwartał 2011 r. Realną stopę procentową zdefiniowano jako trzymiesięczną stopę procentową WIBOR pomniejszoną o wskaźnik CPI. Dane o poziomie realnego kursu walutowego otrzymano ze strony internetowej BIS ${ }^{5}$. Kwartalne stopy procentowe WIBOR obliczono jako średnie arytmetyczne dziennych stóp procentowych publikowanych na stronie www.money.pl.

Jak wynika z wykresu 5.1, realny efektywny kurs walutowy charakteryzował się zmienną tendencją w całym analizowanym okresie. Do II kwartału 2002 r. (z pewnymi wahaniami) realny efektywny kurs walutowy rósł ${ }^{6}$. Od III kwartału 2002 do I kwartału 2004 r. mieliśmy do czynienia ze spadkiem realnego efektywnego kursu walutowego (czyli aprecjacją złotego). Po przystąpieniu Polski do UE do I kwartału 2005 r. tendencja ta uległa odwróceniu. Pewna stabilizacja realnego efektywnego kursu walutowego w Polsce nastąpiła w okresie II kwartał 2005 - I kwartał 2007 r. Od II kwartału 2007 r. do III kwartału 2008 r. miało miejsce sukcesywne osłabianie się złotego w stosunku do innych walut. Kulminacja

\footnotetext{
${ }^{5}$ Bank for International Settlements, www.bis.org/statistics/eer/index.htm(dostęp: 25.06.2012).

${ }^{6}$ Wzrost realnego efektywnego kursu walutowego oznacza deprecjację złotego.
} 
osłabienia złotego miała miejsce w przedziale od I do III kwartału 2008, co było spowodowane silnym atakiem spekulacyjnym. Od IV kwartału 2008 do II kwartału 2009 r. wystąpiła aprecjacja złotego. W następnych kwartałach kurs polskiej waluty zaczął się znowu osłabiać.

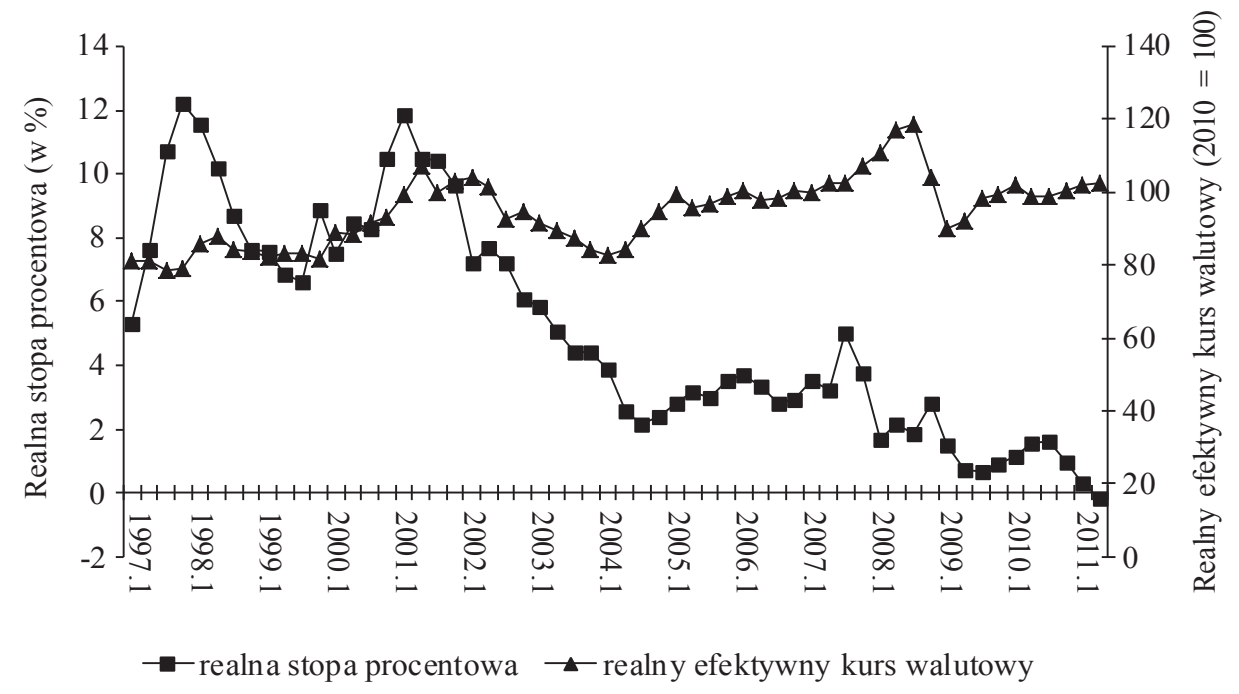

Wykres 5.1. Poziom realnych stóp procentowych i realnego kursu walutowego (rok $2010=100$ ) w Polsce w okresie I kwartał 1997 - II kwartał 2011 r.

Źródło: obliczenia własne na podstawie: www.stat.gov.pl; www.bis.org/statistics/eer/index. htm; www.money.pl.

Z wykresu 5.1 wynika, że w całym analizowanym okresie były znaczne wahania realnej stopy procentowej. W całym 1997 r. wystąpiła dosyć silna tendencja wzrostowa realnej stopy procentowej w Polsce. Od I kwartału 1998 r. do III kwartału 1999 r. wystąpił spadek realnej stopy procentowej (w tym okresie realna stopa procentowa zmalała o prawie 5 punktów procentowych). Od IV kwartału 1999 do I kwartału 2001 r. realna stopa procentowa wzrosła o prawie 3 punkty procentowe. Tendencja wzrostowa realnych stóp procentowych uległa odwróceniu w okresie II kwartał 2001 - III kwartał 2004 r. Spadki realnych stóp procentowych miały miejsce również w następujących podokresach:

- IV kwartał 2004 - III kwartał 2007 r.,

- II-IV kwartał 2008 r.,

- IV kwartał 2009 - III kwartał 2010 r.

W pozostałych podokresach realne stopy procentowe rosły. Należy podkreślić, że do końca 2002 r. realna stopa procentowa utrzymywała się na poziomie powyżej $6 \%$. 


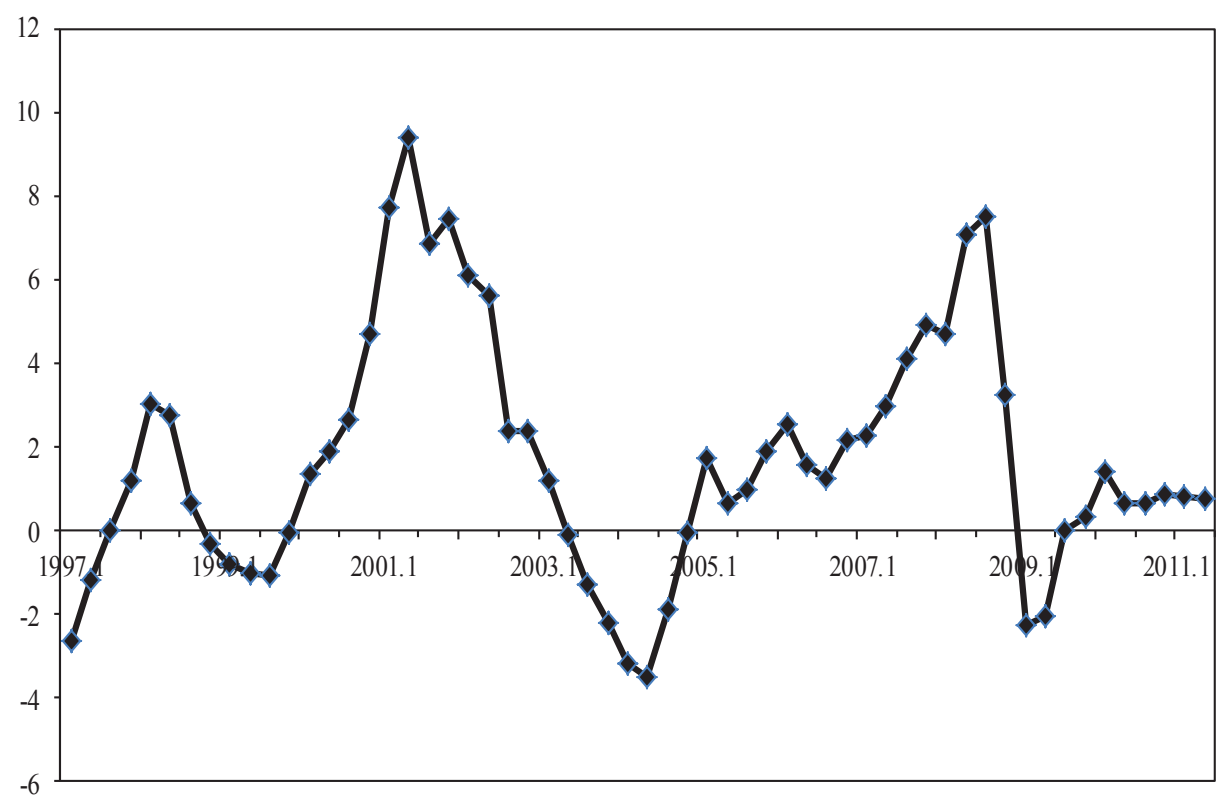

Wykres 5.2. Wartości wskaźnika MCI w Polsce w okresie I kwartał 1997 - II kwartał 2011 r.

Źródło: jak do wykresu 5.1; obliczenia własne.

Na wykresie 5.2 przedstawiono dane o wysokości wskaźnika $M C I$ oszacowanego w oparciu o równanie (5.1). Do obliczeń wskaźnika $M C I$ trzeba przyjąć pewien okres bazowy, w którym polityka pieniężna jest neutralna. Ponieważ w III kwartale 2009 r. nie następowały zmiany stóp procentowych NBP, wybrano go jako okres bazowy. Trzeba podkreślić, że zmiana okresu bazowego wpływa tylko na wysokość indeksu, a nie na kierunek zmian jego wartości.

Przyjmujemy, zgodnie z oszacowaniami publikowanymi przez NBP, że parametr $\alpha_{1}$ wynosi 0,66 , a parametr $\alpha_{2}$ wynosi 0,33 (zob. Raport o inflacji $w$ III kwartale 2003 r., 2003) ${ }^{7}$. Taki stosunek wag oznacza, że zmiana o 1 punkt procentowy realnej stopy procentowej ma taki sam wpływ na aktywność gospodarczą i inflacje, jak zmiana realnego kursu walutowego o 2 punkty procentowe.

Na podstawie wykresu 5.2 można wyróżnić następujące etapy zmian indeksu $M C I$, które są dosyć ściśle powiązane z okresami zmian stóp procentowych NBP:

- I kwartał 1997 - I kwartał 1998 r. - wzrost indeksu MCI,

- II kwartał 1998 - III kwartał 1999 r. - spadek indeksu MCI,

- IV kwartał 1999 - II kwartał 2001 r. - wzrost indeksu MCI,

- III kwartał 2001 - II kwartał 2004 r. - spadek indeksu MCI,

- III kwartał 2004 - I kwartał 2005 r. - nieznaczny wzrost $M C I$,

${ }^{7}$ Kot wykazał, że indeks $M C I$ słabo reaguje na zmiany wag w rozsądnym zakresie przy stopie procentowej i kursie walutowym (zob. Kot 2003b, s. 4). 
- II kwartał 2005 - I kwartał 2007 r. - pewna stabilizacja indeksu MCI,

- II kwartał 2007 - III kwartał 2008 r. - wzrost indeksu MCI,

- IV kwartał 2008 - I kwartał 2009 r. - silny spadek indeksu MCI,

- II kwartał 2009 - I kwartał 2010 r. - wzrost indeksu MCI,

- II kwartał 2010 - II kwartał 2011 r. - stabilizacja indeksu MCI.

Wzrost indeksu $M C I$ oznacza zwiększenie stopnia restrykcyjności polityki pieniężnej, natomiast jego spadek oznacza złagodzenie polityki pieniężnej. Stabilizacja indeksu oznacza, że polityka pieniężna w tym okresie miała charakter neutralny.

W latach 1999-2001 nastąpiło znaczne zwiększenie stopnia restrykcyjności polityki pieniężnej w Polsce. Jak wynika z wykresu 5.2, w tym okresie nastąpił dosyć dynamiczny wzrost indeksu MCI przy jednoczesnym wzroście realnej stopy procentowej. Wzrost realnej stopy procentowej przyczynił się do aprecjacji złotego w tym okresie (zobacz wykres 5.1 oraz 5.3). Rada Polityki Pieniężnej zdawała sobie sprawę z tego, iż główną przyczyną znacznego wzrostu inflacji w $1999 \mathrm{r}$. były szoki podażowe, jednak pomimo tego zdecydowała się na podniesienie stóp procentowych. W ten sposób chciała zwiększyć zaufanie rynku do skuteczności działań NBP w walce z inflacją (zob. Szczurek 2011, s. 160).

Również w okresie III kwartał 2004 - I kwartał 2005 r. polityka pieniężna wydaje się zbyt restrykcyjna. Przeprowadzone obniżki stóp procentowych NBP w tym okresie były zbyt niskie, ponieważ po wejściu do UE kurs złotego znacznie się umocnił, co dawało pole do głębszych obniżek stóp procentowych. Potwierdzeniem tezy o zbyt dużej restrykcyjności polityki pieniężnej w tym okresie jest szybki spadek inflacji poniżej celu inflacyjnego (zob. Próchnicki 2011, s. 107).

Kolejny okres zaostrzenia polityki pieniężnej rozpoczął się w II kwartale 2007 r., a zakończył w III kwartale 2008 r. Od 2007 do czerwca 2008 r. RPP dokonała serii podwyżek stóp procentowych NBP. Silny wzrost stopnia restrykcyjności polityki pieniężnej w latach 2007-2008 był spowodowany przede wszystkim znacznym umocnieniem się kursu złotego w tym okresie (zob. wykres 4.1).

Z kolei spadek stopnia restrykcyjności polityki pieniężnej na przełomie 2008 i 2009 r. był - jak wynika z wykresu 5.1 - wspomagany przez silną deprecjację złotego. Od listopada 2008 do czerwca 2009 r. RPP obniżyła stopę referencyjną NBP aż o 250 punktów bazowych.

Na wykresie 5.3 przedstawiono tendencje zmian realnej stopy procentowej oraz wskaźnika CPI w Polsce w okresie I kwartał 1997 - II kwartał 2011 r. $\mathrm{Z}$ wykresu 5.3 wynika, że w analizowanym okresie występowała dosyć znaczna korelacja między poziomem wskaźnika $C P I^{8}$ a poziomem realnej stopy procentowej. Współczynnik korelacji między tymi wskaźnikami wyniósł 0,608. W badanym okresie (pomimo pewnych wahań) wystąpiła tendencja spadkowa realnych

\footnotetext{
${ }^{8}$ Aby zapewnić przejrzystość wykresów zamiast indeksu przedstawiono stopę wzrostu cen dóbr i usług konsumpcyjnych.
} 
stóp procentowych i wskaźnika CPI. Pomimo pewnych zastrzeżeń co do stopnia restrykcyjności realizowanej polityki pieniężnej niewątpliwym sukcesem tej polityki jest trwałe obniżenie inflacji i stóp procentowych.

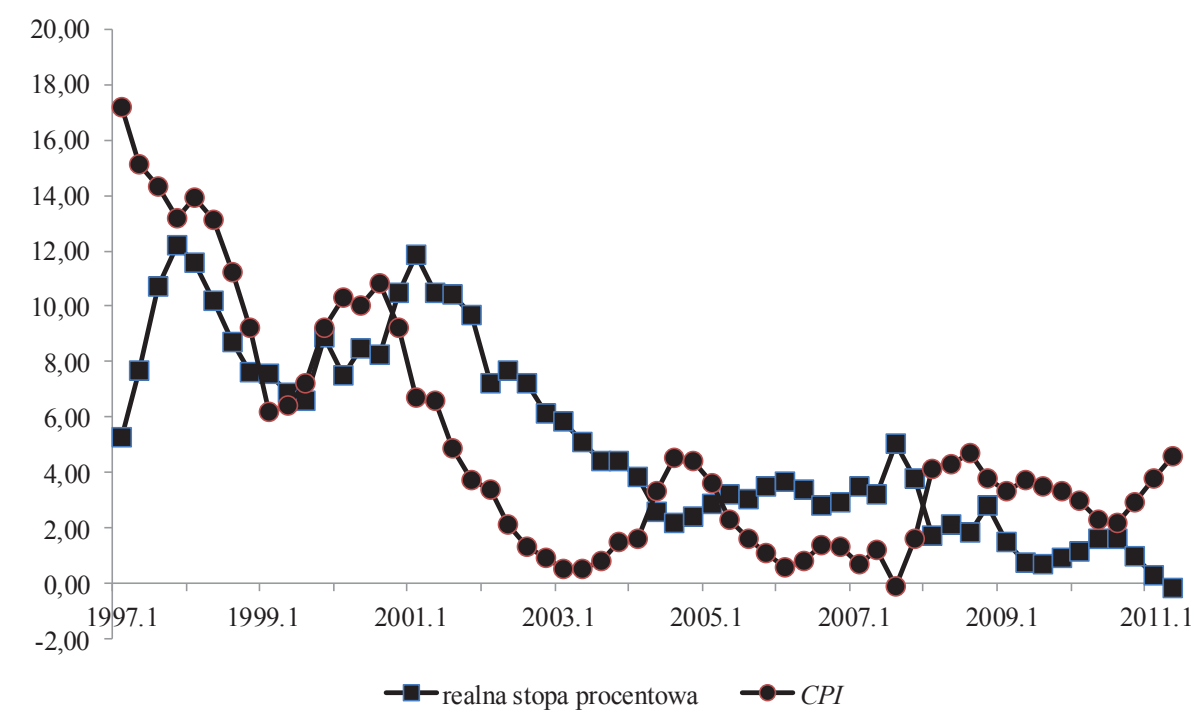

Wykres 5.3. Realna stopa procentowa i wskaźnik $C P I^{a}$ w Polsce, I kwartał 1997 - II kwartał $2011 \mathrm{r}$.

${ }^{a} \mathrm{~W}$ stosunku do odpowiedniego kwartału poprzedniego roku.

Źródło: dane o stopach procentowych WIBOR3M: www.money.pl oraz dane GUS: www.stat. gov.pl.

Wykres 5.4 przedstawia tendencje zmian stopy bezrobocia NAIRU oraz wskaźnika CPI w Polsce w okresie I kwartał 1997 - II kwartał 2011 r. W tym rozdziale wykorzystywano szacunki bezrobocia równowagi w oparciu o rozszerzoną krzywą Phillipsa przedstawione w poprzednim rozdziale. Z wykresu 5.4 wynika, że w początkowym okresie wzrostowi stopy bezrobocia NAIRU towarzyszył dosyć silny spadek wskaźnika CPI. Od przełomu 2003 i 2004 r. tendencja ta uległa odwróceniu. Do I kwartału 2004 r. obserwujemy sukcesywny spadek NAIRU, natomiast wskaźnik CPI przy pewnych wahaniach utrzymywał się na stosunkowo niskim poziomie. A zatem poziom NAIRU, który stabilizuje inflację w Polsce, jest w dalszym ciągu stosunkowo wysoki i w żadnym kwartale nie osiągnął poziomów zakładanych w niektórych opracowaniach (zob. Próchnicki 2011, s. 111). Co więcej, w omawianych w rozdziale trzecim wynikach oszacowań dla Polski również nie uzyskano oszacowania NAIRU dla Polski na poziomie 3,5\%. 


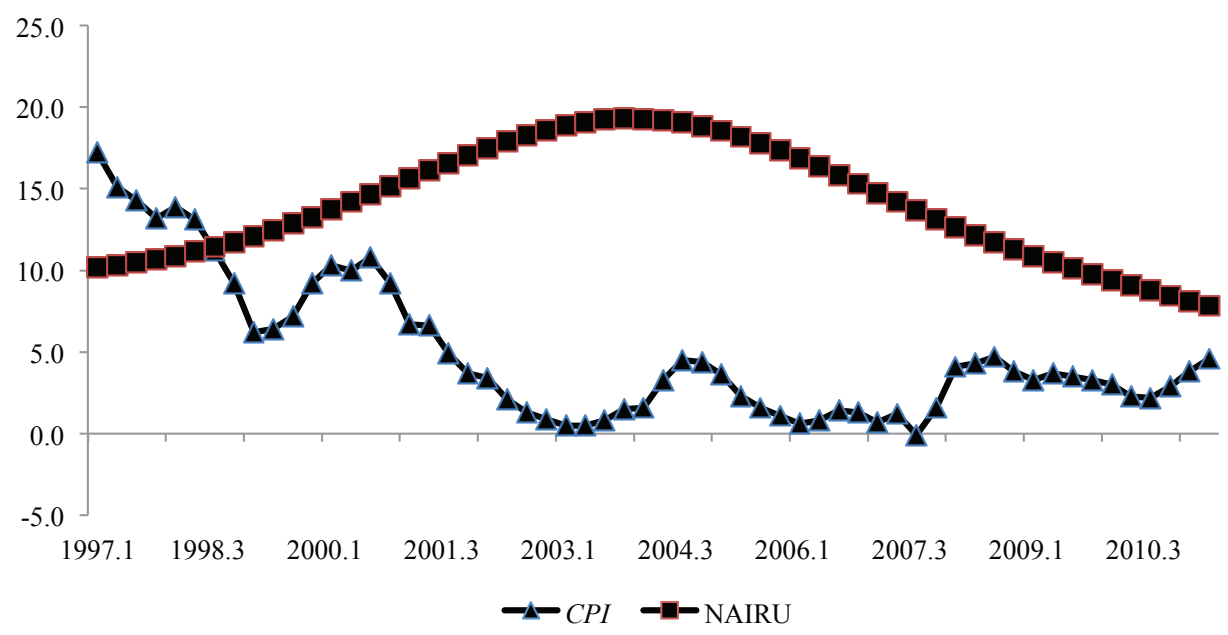

Wykres 5.4. Stopa bezrobocia NAIRU ${ }^{a}$ oraz wskaźnik $C P I^{b}$ w Polsce w okresie I kwartał 1997 - II kwartał $2011 \mathrm{r}$.

${ }^{a}$ dane wygładzone, ${ }^{b} \mathrm{~W}$ stosunku do odpowiedniego kwartału poprzedniego roku.

Źródło: jak do wykresu 5.3; obliczenia własne.

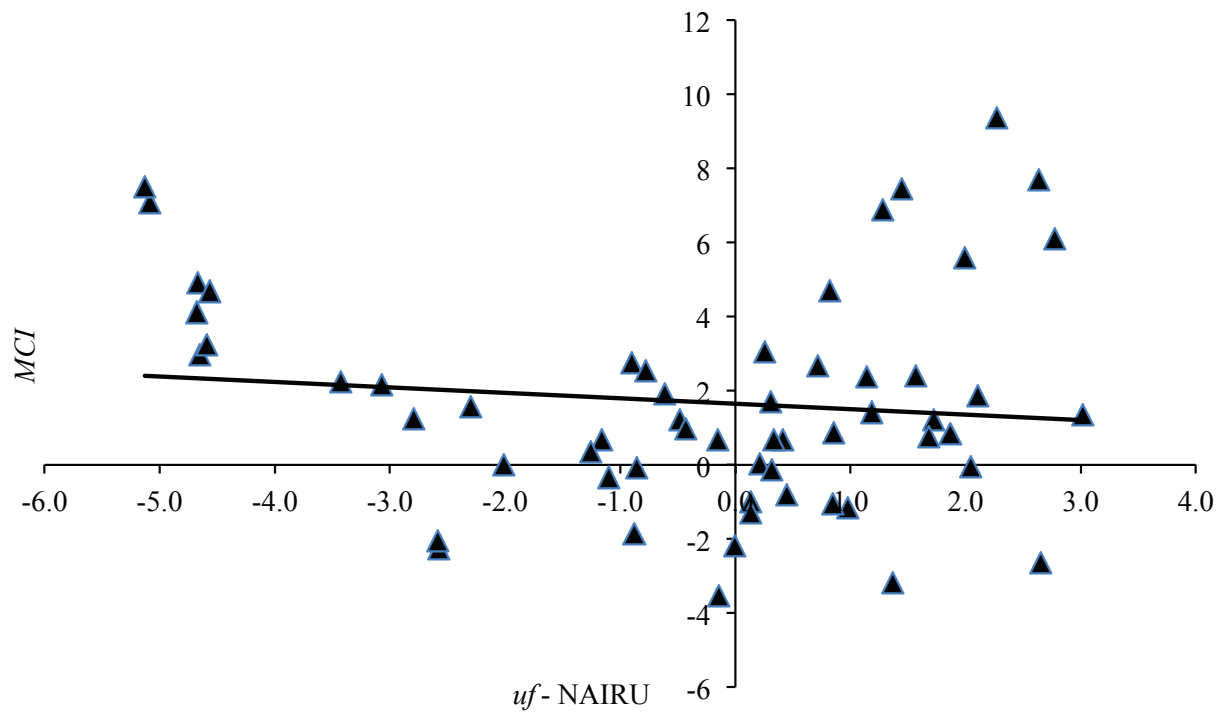

Wykres 5.5. Zależność między poziomem indeksu $M C I$ a różnicą między faktyczną stopą bezrobocia $(u f)$ a stopą bezrobocia NAIRU w Polsce, I kwartał 1997 - II kwartał $2011 \mathrm{r}$. Źródło: jak do wykresu 5.3; obliczenia własne. 
Na wykresie 5.5 przedstawiono zależność między wskaźnikiem $M C I$ a różnicą między faktyczną stopą bezrobocia $(u f)$ a stopą bezrobocia NAIRU. Z wykresu tego wynika, że w badanych latach występowała słaba ujemna zależność między wskaźnikiem $M C I$ a poziomem stopy bezrobocia w równowadze. Wskaźnik korelacji między tymi wielkościami kształtował się na poziomie $-0,112$. Kierunek zależności jest zgodny z teorią. Zmiana relacji między faktyczną stopą bezrobocia a NAIRU w niewielkim stopniu wpływała na stopień restrykcyjności polityki pieniężnej. Z wykresu 5.5 wynika jednak, że odrzucenie kilkunastu kwartałów (punkty rozproszone po prawej stronie wykresu oraz dwa punkty po lewej stronie od góry) znacznie wzmocniłoby zależność między tymi zmiennymi.

Należy również pamiętać, że polityka pieniężna oddziałuje na gospodarkę z pewnym opóźnieniem, dlatego też warto przyjrzeć się zależności między wartością $M C I$ a różnicą między faktyczną stopą bezrobocia a stopą bezrobocia NAIRU opóźnioną w czasie.

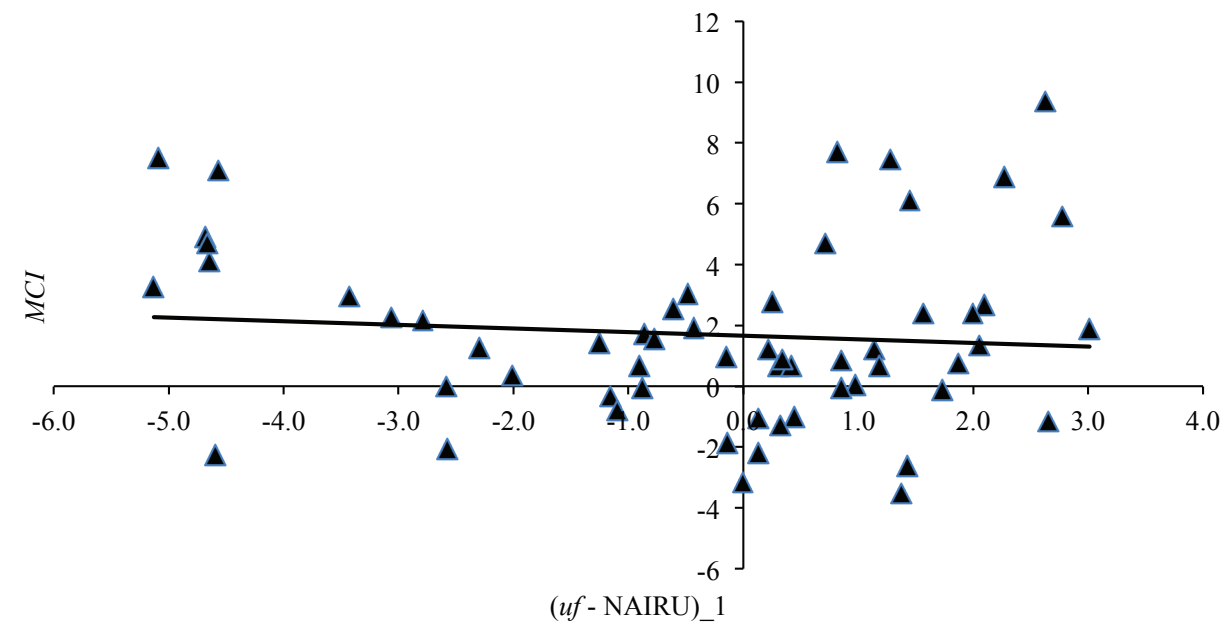

Wykres 5.6. Zależność między poziomem indeksu $M C I$ a różnicą między faktyczną stopą bezrobocia $(u f)$ i stopą bezrobocia NAIRU ${ }^{a}$ opóźnioną o jeden kwartał w Polsce, I kwartał 1997 - II kwartał $2011 \mathrm{r}$.

${ }^{a}$ dane wygładzone.

Źródło: jak do wykresu 5.3; obliczenia własne.

Jak wynika z wykresów 5.6-5.7 opóźniona o jeden i dwa kwartały różnica między faktyczną stopą bezrobocia a NAIRU w jeszcze mniejszym stopniu wpływała na poziom indeksu $M C I \mathrm{w}$ analizowanym okresie. Można więc wysnuć wniosek, że w badanym okresie zmiana relacji między faktyczną stopą bezrobocia a NAIRU w niewielkim stopniu była związana ze stopniem restrykcyjności polityki pieniężnej w analizowanym okresie. Współczynnik korelacji między 
indeksem $M C I$ a różnicą między faktyczną stopą bezrobocia i stopą bezrobocia NAIRU opóźnioną o jeden kwartał oraz o dwa kwartały wynosi odpowiednio: $-0,09$ oraz $-0,06$.

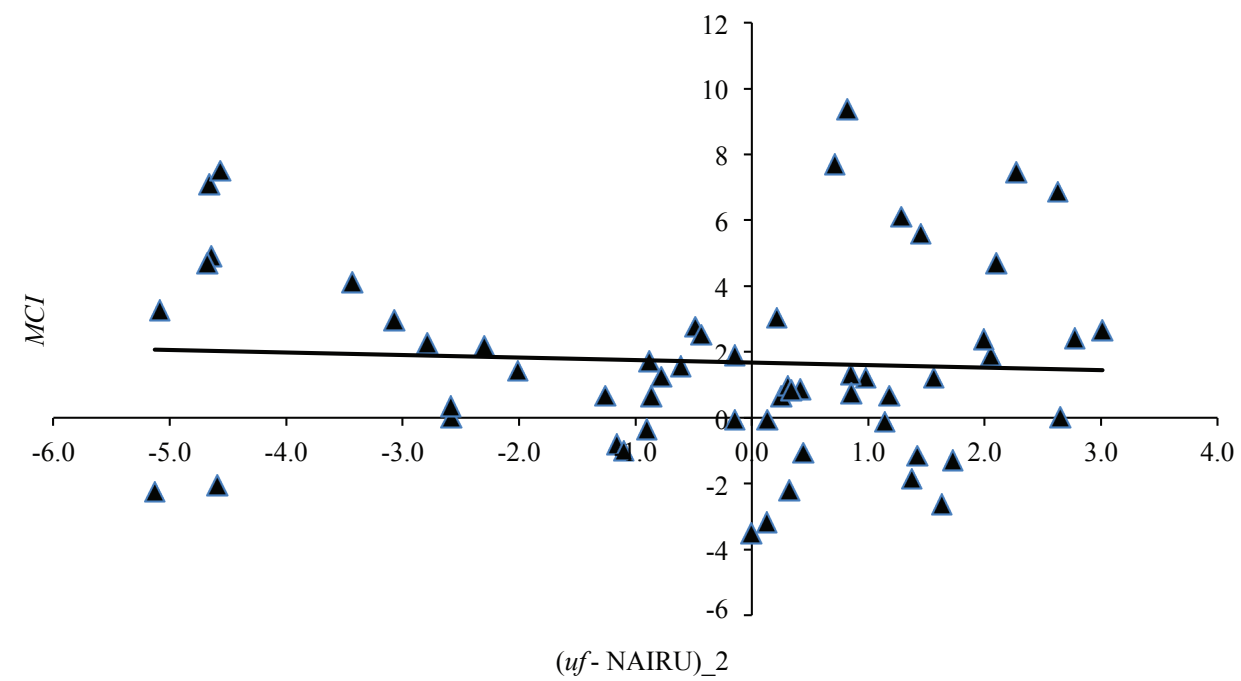

Wykres 5.7. Zależność między poziomem indeksu MCI a różnicą między faktyczną stopą bezrobocia $(u f)$ i stopą bezrobocia NAIRU ${ }^{a}$ opóźnioną o dwa kwartały w Polsce, I kwartał 1997 - II kwartał $2011 \mathrm{r}$.

${ }^{a}$ dane wygładzone.

Źródło: jak do wykresu 5.3, obliczenia własne.

\subsection{Polityka fiskalna a bezrobocie równowagi}

\subsubsection{Pojęcie i miary restrykcyjności polityki fiskalnej}

Celem tego podrozdziału jest odpowiedź na pytanie, czy zmiany relacji między faktyczną stopą bezrobocia a stopą bezrobocia równowagi były związane ze stopniem restrykcyjności polityki fiskalnej w Polsce w latach 1995-2011. Pewnym ograniczeniem dla prowadzonych analiz jest stosunkowo krótki szereg czasowy.

Polityka fiskalna polega na podejmowaniu przez rząd decyzji odnośnie poziomu i struktury wydatków budżetowych, źródeł ich sfinansowania oraz deficytu budżetowego. Polityka fiskalna razem z polityką pieniężną stanowią jeden z głównych elementów składowych polityki makroekonomicznej. Do głównych celów polityki fiskalnej można zaliczyć: dostarczanie dóbr publicznych, zapewnienie 
finansowania niezbędnych wydatków państwa oraz stabilizację koniunktury gospodarczej (zob. Winiarski 2000, s. 444).

Wzrost faktycznej stopy bezrobocia powyżej poziomu bezrobocia równowagi jest oznaką pogorszenia koniunktury gospodarczej, a zatem powinno to skłaniać rząd do złagodzenia polityki fiskalnej w celu zmniejszenia nadwyżki faktycznej stopy bezrobocia nad stopą bezrobocia równowagi. Oczywiście musimy mieć na względzie fakt, że rząd musi dbać o stan finansów publicznych. Brak dyscypliny finansów publicznych jest przyczyną obecnego kryzysu finansowego w strefie euro.

Do podstawowych narzędzi tej polityki zaliczamy: stopę podatkową, wydatki publiczne oraz poziom deficytu budżetowego. W zależności od kierunku zmian dochodów i wydatków budżetowych możemy wyróżnić ekspansywną oraz restrykcyjną politykę fiskalną. Ekspansywna polityka fiskalna polega na zwiększaniu wydatków budżetowych lub zmniejszaniu podatków bądź jednoczesnym zwiększaniu wydatków i obniżaniu podatków. Restrykcyjna polityka fiskalna polega na obniżaniu wydatków budżetowych lub/i podnoszeniu podatków.

Celem ekspansywnej polityki fiskalnej jest poprawa koniunktury gospodarczej. Wzrost wydatków budżetowych lub/i spadek podatków prowadzi do wzrostu agregatowego popytu. Wzrost agregatowego popytu prowadzi do wzrostu produkcji i wzrostu zatrudnienia. Wzrost zatrudnienia skutkuje spadkiem bezrobocia. $\mathrm{Na}$ gruncie efektu histerezy można powiedzieć, że spadek bezrobocia faktycznego może prowadzić do obniżenia poziomu bezrobocia NAIRU. Ekspansywna polityka fiskalna może skutkować wzrostem deficytu budżetowego i długu publicznego.

Z kolei celem restrykcyjnej polityki fiskalnej jest redukcja deficytu budżetowego i długu publicznego. Negatywną konsekwencją tej polityki jest zmniejszenie agregatowego popytu w gospodarce i w konsekwencji osłabienie aktywności gospodarczej.

Miarą stopnia restrykcyjności polityki fiskalnej jest najczęściej poziom deficytu budżetowego lub nadwyżki budżetowej. Według A. Wernika takie podejście ma następującą wadę - uzyskany wynik zależy od metody obliczania salda budżetowego. W przypadku Polski można wyróżnić trzy metody jego obliczania (zob. Wernik 2002, s. 201):

- narodową,

- opartą na systemie GFS (A Government Finance Statistics) stosowaną przez Międzynarodowy Fundusz Walutowy,

- stosowaną w Unii Europejskiej opartą na ESA 95 (Europejskim Systemie Rachunków Narodowych i Regionalnych).

W wyniku zastosowania każdej z tych metod uzyskuje się inny wynik. Pomimo tych zastrzeżeń przyjmuje się, że im wyższa jest relacja deficytu budżetowego do wydatków rządowych lub PKB, tym mniej restrykcyjna jest polityka fiskalna. 
Z kolei, im niższa jest relacja deficytu budżetowego do poziomu wydatków rządowych lub PKB, tym bardziej restrykcyjna jest polityka fiskalna.

Tak samo jak w przypadku polityki pieniężnej, dla oceny stopnia restrykcyjności polityki fiskalnej wykorzystuje się syntetyczny indeks restrykcyjności tej polityki - FCI (Fiscal Condition Index) (zob. Kot 2003a, s. 24-25). Indeks FCI można opisać wzorem:

$$
F C I=D B_{t}-D B_{b}
$$

gdzie:

$D B_{t}$ - poziom deficytu budżetowego (w relacji do PKB) w okresie $t$, $D B_{b}$ - poziom deficytu budżetowego (w relacji do PKB) w okresie referencyjnym (bazowym).

Wzrost wartości tak zdefiniowanego indeksu $F C I$ oznacza wzrost stopnia restrykcyjności polityki fiskalnej, zaś jego spadek - obniżenie stopnia restrykcyjności tej polityki.

W konstrukcji indeksu $F C I$ można uwzględnić również strukturę finansów publicznych. Indeks $F C I$ można uzależnić od deficytów każdej ze sfer finansów publicznych. Podejście takie jest zasadne w sytuacji, gdy poszczególne dziedziny finansów publicznych wpływają w różnym stopniu na kształtowanie się deficytu budżetowego. Niemniej oszacowanie tak zdefiniowanego indeksu FCI jest utrudnione $\mathrm{z}$ uwagi na częste zmiany $\mathrm{w}$ strukturze finansów publicznych oraz różne definicje ich deficytów (zob. Kot 2003a, s. 25).

$\mathrm{Z}$ uwagi na to, że wydatki budżetowe charakteryzują się znaczną sztywnością, zaś dochody budżetowe zależą w dużym stopniu od stanu koniunktury gospodarczej, dużą popularność w ostatnich latach zyskała koncepcja deficytu strukturalnego. Deficyt strukturalny jest określany również mianem deficytu przy pełnym zatrudnieniu (zob. Hall, Taylor 2000, s. 354). Informuje on, jaka byłaby wielkość deficytu budżetowego w sytuacji pełnego zatrudnienia. Deficyt strukturalny eliminuje wpływ wahań koniunkturalnych na wielkość deficytu budżetowego.

Deficyty strukturalne są szacowane przez MFW, OECD oraz Komisję Europejską. W oparciu o tę koncepcję wskaźnik restrykcyjności polityki fiskalnej można zdefiniować jako różnicę między poziomem deficytu strukturalnego w danym roku a poziomem deficytu strukturalnego w roku bazowym.

Według A. Wernika dla prowadzenia właściwej w danej sytuacji gospodarczej policy mix jako kryterium oceny stopnia restrykcyjności polityki fiskalnej powinno się przyjmować powstający w jej wyniku efekt popytowy (zob. Wernik 2002, s. 202). Jednakże to kryterium jest trudne do zastosowania w analizach empirycznych z uwagi na brak dokładnych danych, dlatego jako miernik stopnia restrykcyjności polityki fiskalnej w dalszej części tego rozdziału będzie przyjmowany wskaźnik $F C I$ zdefiniowany jako różnica między poziomem deficytu budżetowego w danym roku i poziomem deficytu budżetowego w roku bazowym. 


\subsubsection{Stopień restrykcyjności polityki fiskalnej a bezrobocie równowagi}

W niniejszym podrozdziale przedstawiono analizę poziomu deficytu budżetowego w relacji do PKB w Polsce w latach 1995-2011. Jak wynika z wykresu 5.8, w analizowanym okresie występowała zmienna tendencja w zakresie kształtowania się deficytu budżetowego. W całym badanym okresie występował deficyt budżetowy. Okresy wzrostu deficytu budżetowego nie zawsze pokrywały się z osłabieniem koniunktury gospodarczej (np. w 2003 r. i w 2008 r. nastąpił wzrost deficytu budżetowego pomimo dobrej koniunktury). Z kolei w latach 1998-2000, pomimo pogorszenia koniunktury gospodarczej, wystąpił znaczący spadek poziomu deficytu budżetowego.

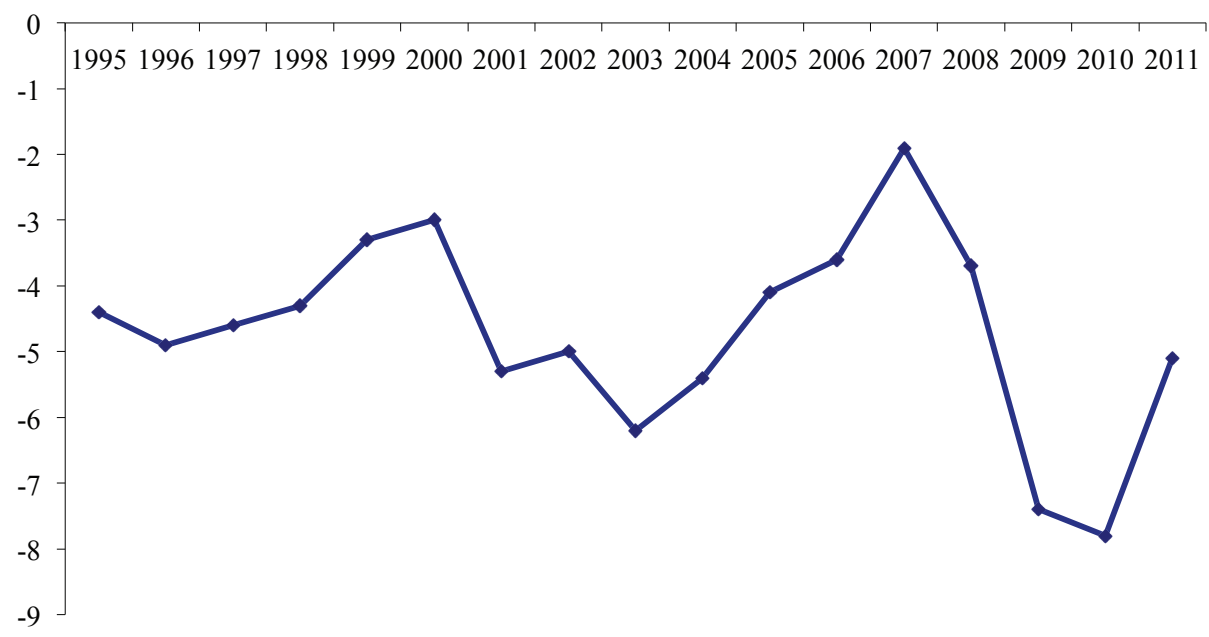

Wykres 5.8. Poziom deficytu budżetowego w relacji do PKB w Polsce w latach 1995-2011 (w \%)

Źródło: http://epp.eurostat.ec.europa.eu/tgm (dostęp: 27.06.2012).

Na wykresie 5.9 przedstawiono dane o wysokości indeksów restrykcyjności polityki fiskalnej FCI. Indeks ten obliczono przy założeniu, że rokiem referencyjnym jest rok 1995. Wybór roku bazowego nie ma znaczenia dla uzyskanych wyników. Z wykresu 5.9 wynika, że w latach 1996-2000 rosła restrykcyjność polityki fiskalnej w Polsce (najsilniej w latach 1998-1999). Bardzo silne ,poluzowanie” polityki fiskalnej nastąpiło w latach 2000-2001. Po lekkiej korekcie w 2002 r. restrykcyjność polityki fiskalnej malała aż do 2003 r. W latach 2003-2007, wraz z poprawą koniunktury gospodarczej, nastąpił znaczący wzrost stopnia restrykcyjności polityki fiskalnej. Wraz z osłabieniem koniunktury gospodarczej w latach 2008-2010 nastąpiło silne ,poluzowanie” polityki fiskalnej. Tendencja ta została zatrzymana w 2011 r., gdy rynki finansowe ,przypomniały” sobie o znacznym wzroście zadłużenia krajów Strefy Euro. Pojawiła się również groźba przekroczenia poziomu 55\% w relacji długu publicznego do PKB. 


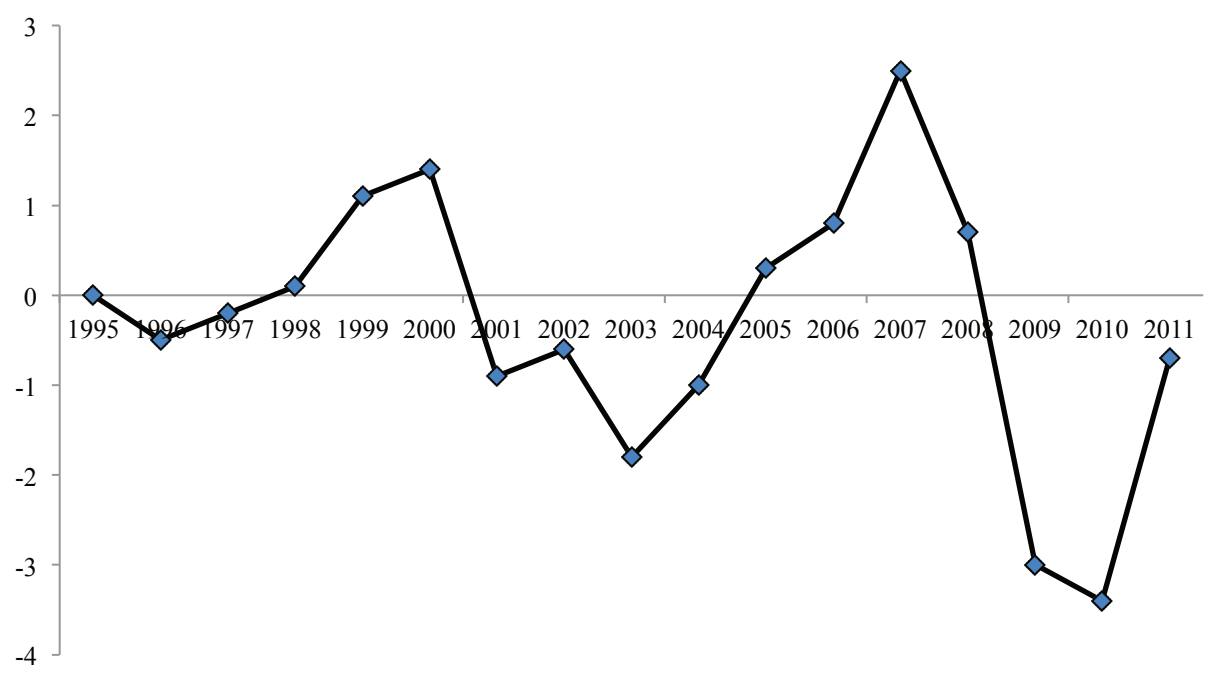

Wykres 5.9. Indeks restrykcyjności polityki fiskalnej FCI (w p.p.)

Źródło: jak do wykresu 5.8; obliczenia własne.

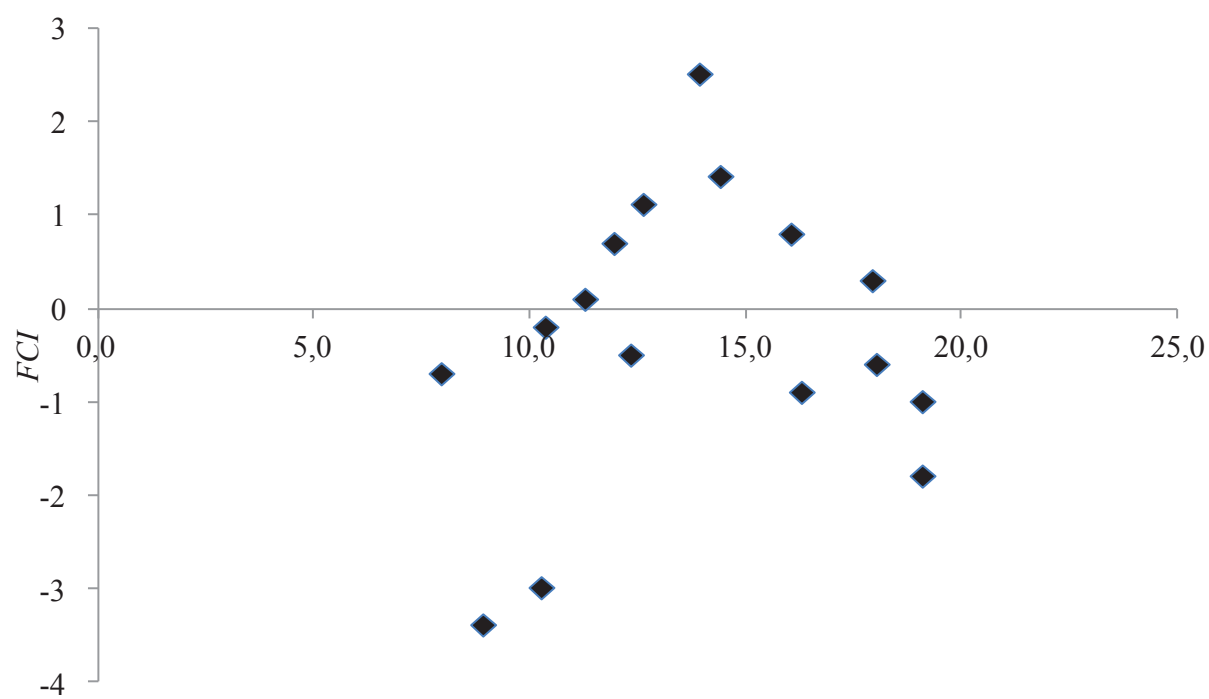

NAIRU

Wykres 5.10. Zależność między indeksem restrykcyjności polityki fiskalnej (FCI) a stopą bezrobocia NAIRU w latach 1995-2011*

* stopę bezrobocia NAIRU obliczono jako średnią kwartalnych stóp bezrobocia NAIRU w danym roku (w 2011 r. roczna stopa bezrobocia NAIRU to średnia stóp NAIRU z I i II kwartału).

Źródło: jak do wykresów 4.3 oraz 5.8; obliczenia własne. 
Przejdźmy zatem do zbadania zależności między stopniem restrykcyjności polityki fiskalnej a relacją między bezrobociem faktycznym i bezrobociem równowagi (NAIRU). Z wykresu 5.10 wynika, że w latach 1995-2011 występowała dosyć słaba dodatnia zależność między indeksem restrykcyjności polityki fiskalnej a poziomem bezrobocia równowagi. Współczynnik korelacji między obydwoma zmiennymi wyniósł ok. 0,17 . Z uwagi na duże rozproszenie obserwacji na wykresie nie można wysuwać jednoznacznych wniosków. Istotniejsza dla polityki fiskalnej powinna być różnica między faktyczną stopą bezrobocia i stopą bezrobocia równowagi a restrykcyjnością tej polityki. Im większa jest bowiem nadwyżka bezrobocia faktycznego nad NAIRU, tym większy poziom bezrobocia cyklicznego, które jest wrażliwe na politykę makroekonomiczną państwa.

Z wykresu 5.11 wynika, że w badanym okresie występowała ujemna zależność między indeksem restrykcyjności polityki fiskalnej a różnicą między faktyczną stopą bezrobocia i stopą bezrobocia NAIRU. A zatem wzrost nadwyżki faktycznej stopy bezrobocia nad NAIRU prowadził do osłabienia stopnia restrykcyjności polityki fiskalnej. Można zatem powiedzieć, że polityka fiskalna w badanym okresie była dostosowana do sytuacji panującej na rynku pracy.

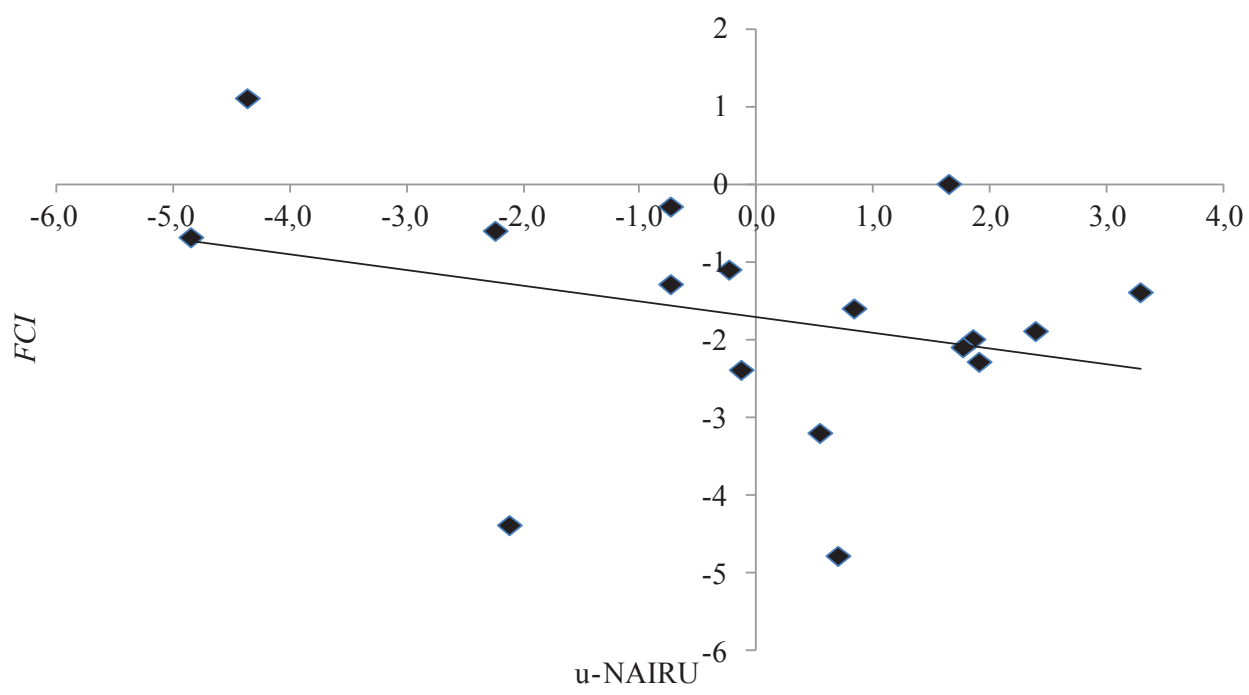

Wykres 5.11. Zależność między indeksem restrykcyjności polityki fiskalnej (FCI) a różnicą między faktyczną stopą bezrobocia a stopą bezrobocia NAIRU w latach 1995-2011*

* stope bezrobocia NAIRU obliczono jako średnią kwartalnych stóp bezrobocia NAIRU w danym roku (w 1995 r. roczna stopa bezrobocia NAIRU to średnia arytmetyczna stóp bezrobocia z III i IV kwartału; w 2011 r. roczna stopa bezrobocia NAIRU to średnia stóp NAIRU z I i II kwartału).

Źródło: jak do wykresu 5.10; obliczenia własne. 
Współczynnik korelacji między tymi zmiennymi wyniósł $-0,312$, nie jest to zatem zależność zbyt silna. Trzeba jednak mieć na uwadze fakt, że analizowany okres jest stosunkowo krótki i niejednorodny. Obejmuje on początkowe lata transformacji systemowej oraz okres światowego kryzysu finansowego, który miał istotny wpływ na polską gospodarkę.

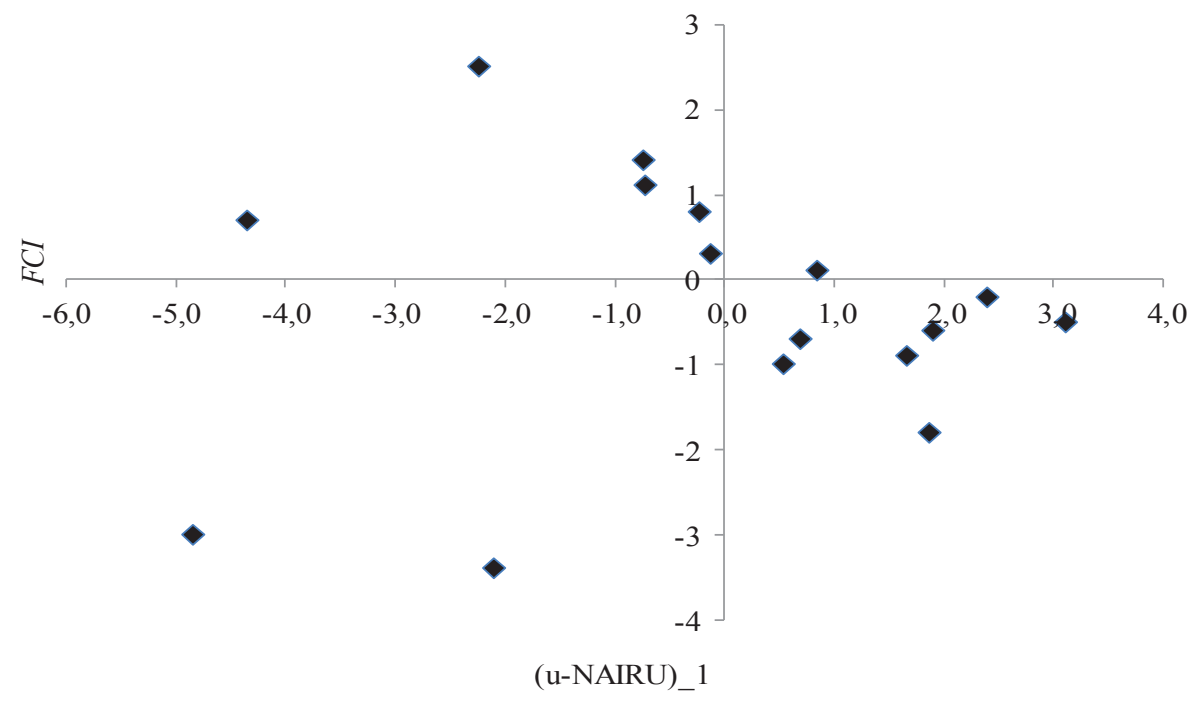

Wykres 5.12. Zależność między indeksem restrykcyjności polityki fiskalnej (FCI) a różnicą między faktyczną stopą bezrobocia a stopą bezrobocia NAIRU opóźnioną o jeden rok w latach 1995-2011*

* stopę bezrobocia NAIRU obliczono jako średnią kwartalnych stóp bezrobocia NAIRU $\mathrm{w}$ danym roku (w $1995 \mathrm{r}$. roczna stopa bezrobocia NAIRU to średnia arytmetyczna stóp bezrobocia z III i IV kwartału; w 2011 r. roczna stopa bezrobocia NAIRU to średnia stóp NAIRU z I i II kwartału).

Źródło: jak do wykresu 5.10; obliczenia własne.

Zarówno polityka fiskalna, jak i polityka pieniężna wpływa na gospodarkę z pewnym opóźnieniem. Na wykresie 5.12 przedstawiono zależność między indeksem restrykcyjności polityki fiskalnej $(F C I)$ a różnicą między faktyczną stopą bezrobocia i stopą bezrobocia NAIRU opóźnioną o 1 okres (czyli (u-NAIRU)_1). Jednakże uzyskane rezultaty nie są jednoznaczne. Mała liczba obserwacji oraz występowanie obserwacji nietypowych nie pozwala na wysunięcie jednoznacznych wniosków. Współczynnik korelacji między obydwoma zmiennymi wyniósł 0,024. Jednakże współczynnik korelacji między tymi zmiennymi w latach 1995-2007 wynosi $-0,826$. Można zatem wysnuć wniosek, że zmiany relacji między faktyczną stopą bezrobocia a stopą bezrobocia NAIRU wpływały silnie na stopień 
restrykcyjności polityki fiskalnej w tym przedziale czasowym. Wzrost różnicy między faktyczną stopą bezrobocia a NAIRU prowadził do osłabienia stopnia restrykcyjności polityki fiskalnej w tym okresie.

\subsection{Podsumowanie}

W badanym okresie zarówno polityka pieniężna, jak i polityka fiskalna cechowały się dosyć dużymi zmianami stopnia ich restrykcyjności. Z przeprowadzonych analiz wynika, że w tym przedziale czasowym zmiana relacji między faktyczną stopą bezrobocia a stopą bezrobocia równowagi stosunkowo słabo wpływała na stopień restrykcyjności polityki pieniężnej NBP. Należy jednak pamiętać, że głównym celem NBP jest stabilizacja cen, natomiast stabilizacja koniunktury gospodarczej jest celem dodatkowym. Badany okres nie był jednorodny pod względem wysokości stóp inflacji. Ponadto, dysponowano zbyt małą liczbą obserwacji. Należy podkreślić, że uwzględnienie opóźnień w analizie nie miało wpływu na uzyskane wyniki.

$\mathrm{Z}$ analizy wpływu zmiany różnicy między faktyczną stopą bezrobocia a stopą bezrobocia równowagi na stopień restrykcyjności polityki fiskalnej wynika, że wzrost tej różnicy prowadził do obniżenia stopnia restrykcyjności tej polityki w danym roku. Uwzględnienie opóźnienia o jeden rok dla całego okresu nie dało jednoznacznych wyników. Jednakże w latach 1995-2007 uzyskano bardzo silną ujemną zależność między indeksem restrykcyjności polityki fiskalnej a różnicą między faktyczną stopą bezrobocia a stopą bezrobocia NAIRU opóźnioną o jeden rok. $Z$ uwagi na stosunkowo krótki szereg czasowy do uzyskanych wyników należy jednak podchodzić z dużą ostrożnością. 


\section{Zakończenie}

Zagadnienie bezrobocia jest od dawna badane w teorii ekonomii, choć bardziej dojrzałe analizy podjęto dopiero w XX w. Warto tutaj podkreślić koncepcje teoretyczne ekonomii neoklasycznej, w których podjęto problem bezrobocia dobrowolnego. W badania tego obszaru duży wkład miał Keynes, akcentujący znaczenie idei bezrobocia cyklicznego zależnego od stanu koniunktury gospodarczej. W latach 70. i 80. XX w. wysunięto ideę bezrobocia słabo związanego $\mathrm{z}$ koniunkturą gospodarczą, a mianowicie naturalnej stopy bezrobocia i NAIRU. Są to formy bezrobocia równowagi.

Bezrobocie równowagi jest przedmiotem analiz najważniejszych kierunków współczesnej myśli ekonomicznej, a w szczególności monetaryzmu i nowej szkoły keynesowskiej. Największy wkład w rozwój tej koncepcji mieli M. Friedman, E. S. Phelps, R. Layard oraz Ch. A. Pissarides.

Koncepcja naturalnej stopy bezrobocia od początku swojego istnienia stała się przedmiotem ożywionych sporów ekonomistów. Główną osią konfliktów między keynesistami i monetarystami była kwestia nieefektywności polityki pieniężnej na rynku pracy w długim okresie. W połowie lat 70. XX w. nowi klasycy wysunęli tezę, że krzywa Phillipsa jest pionowa zarówno w krótkim, jak i długim okresie, co tym samym podważało przekonanie o pozytywnym wpływie polityki pieniężnej na bezrobocie nawet $\mathrm{w}$ okresie krótkim.

Teoria NAIRU została sformułowana przez nowych keynesistów w odpowiedzi na rosnącą popularność koncepcji naturalnej stopy bezrobocia. Poziom stopy bezrobocia NAIRU, tak samo jak poziom naturalnej stopy bezrobocia, zależy również od czynników realnych.

W ramach strukturalistycznej teorii bezrobocia została podjęta próba endogenizacji naturalnej stopy bezrobocia. W tej koncepcji podkreślono, że poziom bezrobocia równowagi zmienia się $\mathrm{w}$ czasie i zależy nie tylko od sytuacji na rynku pracy, lecz także od sytuacji na rynku dóbr i rynku kapitałowym.

$\mathrm{Z}$ teorii histerezy wynika natomiast, że na poziom bezrobocia równowagi mają wpływ wahania aktywności gospodarczej. Stopa bezrobocia równowagi może podążać za faktyczną stopą bezrobocia. Stwarza to możliwość wykorzystania polityki makroekonomicznej w celu ograniczania faktycznego poziomu bezrobocia i tym samym ograniczania bezrobocia równowagi. 
$\mathrm{Z}$ przedstawionych teorii bezrobocia równowagi można wywnioskować, że poziom tego bezrobocia zależy do szeregu czynników. Na gruncie teorii naturalnej stopy podkreślono także takie determinanty bezrobocia równowagi, jak: efektywność funkcjonowania urzędów pracy, stopień uzwiązkowienia, wysokość płacy minimalnej, przepływ informacji o wolnych miejscach pracy, wysokość zasiłków dla bezrobotnych oraz okres ich pobierania, struktura zasobu siły roboczej, wysokość kosztów pracy, elastyczność płac, koszty szkoleń, poziom mobilności siły roboczej, technologia, wydajność pracy oraz zmiany struktury produkcji, koszty zbierania informacji o dostępnej sile roboczej.

Wysokość stopy bezrobocia NAIRU uzależniono od: zmian struktury siły roboczej (na którą mają wpływ m.in. procesy migracyjne), zmian wydajności pracy, siły związków zawodowych, zmiany struktury dopasowań na rynku pracy oraz prowadzonej polityki społecznej (ochrony miejsc pracy, hojności systemu zasiłkowego itd.).

$\mathrm{Z}$ teorii bezrobocia równowagi sformułowanej przez Ch. A. Pissaridesa wynika natomiast, że poziom bezrobocia w warunkach stanu stacjonarnego zależy od: stopy likwidacji (destrukcji) miejsc pracy, prawdopodobieństwa odpływu z bezrobocia do zatrudnienia, pozarynkowych dochodów bezrobotnych (czyli zasiłków dla bezrobotnych), realnej stopy procentowej, wydajności pracy, siły przetargowej pracy.

Ze strukturalistycznej teorii bezrobocia równowagi E. S. Phelpsa można wysnuć wniosek, że poziom bezrobocia równowagi zależy od wysokości realnych stóp procentowych, poziomu dochodów pozapłacowych, hojności systemu zasiłków dla bezrobotnych oraz poziomu prawnej ochrony zatrudnienia.

Z kolei w koncepcji histerezy podkreślono, że również wahania aktywności gospodarczej mają wpływ na poziom bezrobocia równowagi. Przyczyn wzrostu bezrobocia równowagi upatruje się w ubytku kapitału ludzkiego, kapitału rzeczowego oraz w zachowaniu się ,insiderów”. Według tych koncepcji także intensywność poszukiwań oraz wysokość płacy progowej mają wpływ na szansę znalezienia pracy i tym samym na poziom bezrobocia równowagi.

W pracy przeprowadzono analizy empiryczne polskiego rynku pracy. Wynika z nich, że w latach 1995-2012 sytuacja na polskim rynku pracy uległa diametralnej poprawie. W okresie przedakcesyjnym Polska zaliczała się do państw z najwyższymi stopami bezrobocia w Europie. Również w początkowych latach po wejściu do UE Polska charakteryzowała się najwyższymi stopami bezrobocia w krajach UE. Jednakże w latach 2006-2008, dzięki przyspieszeniu wzrostu gospodarczego oraz stopniowemu otwieraniu rynków pracy krajów UE-15, sytuacja na polskim rynku pracy uległa diametralnej poprawie. Niemniej w dalszym ciągu stopa bezrobocia utrzymuje się na stosunkowo wysokim poziomie. Pogorszenie koniunktury gospodarczej od 2009 r. przyczyniło się do wzrostu bezrobocia w Polsce, nie był on jednak tak silny, jak w okresie od $1999 \mathrm{r}$. do I kwartału 2004 r. 
Istotnym problemem polskiego rynku pracy jest stosunkowo wysoki poziom bezrobocia długookresowego.

W badanym okresie utrzymywało się dosyć silne zróżnicowanie stóp bezrobocia według wieku, płci, wykształcenia, województw oraz w przekroju miasto-wieś. Utrzymywanie się wysokich stóp bezrobocia wśród młodzieży może wskazywać na niedopasowanie kwalifikacji tej grupy do potrzeb rynku pracy. Niski poziom stóp bezrobocia wśród osób w wieku 45 lat i więcej nie oznacza, że znajdują się one w uprzywilejowanej sytuacji na rynku pracy. Wynika raczej $\mathrm{z}$ dużo mniejszego poziomu aktywności zawodowej jednostek w wieku przedemerytalnym. Jak wynika z przeprowadzonych analiz, osoby powyżej 55 roku życia były w największym stopniu zagrożone bezrobociem długookresowym. Z kolei utrzymywanie się zróżnicowania stóp bezrobocia według wykształcenia oraz w przekroju miasto-wieś jednoznacznie wskazuje na utrzymywanie się niedopasowań strukturalnych, co potwierdzono w analizie indeksów niedopasowań.

Należy podkreślić, iż w latach 2000-2012 zmniejszało się zróżnicowanie stóp bezrobocia według województw. Niektóre województwa w całym badanym okresie znajdowały się jednak wśród regionów o najwyższym poziomie stóp bezrobocia.

Analizy empiryczne wskazują na utrzymywanie się niedopasowań strukturalnych zwłaszcza w przekroju zawodów i wykształcenia. W celu ograniczenia tych niedopasowań konieczne jest dostosowanie systemu edukacji do potrzeb rynku pracy. Należy przede wszystkim rozwijać szkolnictwo zawodowe.

W niniejszej pracy podjęto analizy empiryczne dotyczące własnych szacunków bezrobocia równowagi w Polsce w oparciu o wybrane metody przepływów siły roboczej oraz rozszerzoną krzywą Phillipsa. Oszacowania stóp bezrobocia w warunkach stanu stacjonarnego w oparciu o metody przepływów są do siebie zbliżone. Są one również porównywalne (w tych samych okresach) do wyników opublikowanych przez innych ekonomistów. Również szacunki stóp bezrobocia NAIRU na podstawie rozszerzonej krzywej Phillipsa są porównywalne z wynikami uzyskanymi w oparciu o metody przepływów siły roboczej. Poziom bezrobocia NAIRU oszacowany w oparciu o rozszerzoną krzywą Phillipsa wynosił 9,8\% na koniec IV kwartału 1995 r., a na koniec IV kwartału 2000 r. 15,1\%. Na przełomie 2003 i 2004 r. poziom bezrobocia NAIRU w Polsce osiągnął maksimum $\mathrm{w}$ analizowanym okresie $-19,3 \%$. W kolejnych latach wraz z poprawą sytuacji na rynku pracy zmniejszał się poziom bezrobocia NAIRU. W IV kwartale 2008 r. poziom bezrobocia NAIRU wyniósł 11,3\%, zaś w II kwartale 2011 r. 7,8\%.

Wraz ze zmianami poziomu bezrobocia ogółem zmieniał się także poziom bezrobocia równowagi. Z przeprowadzonych analiz wynika, że poziom bezrobocia równowagi w Polsce (niezależnie od wykorzystanych metod do jego szacowania) podążał za faktyczną stopą bezrobocia. W latach 1995-2011 występowała 
też dodania zależność między stopą bezrobocia równowagi a odsetkiem bezrobotnych długookresowo. Może to wskazywać na występowanie zjawiska histerezy bezrobocia. Konieczne jest zatem podjęcie bardziej zdecydowanych działań w kierunku aktywizacji zawodowej bezrobotnych długookresowo.

Pomimo znacznej poprawy sytuacji na rynku pracy w Polsce w dalszym ciągu w skali całego kraju utrzymuje się wysoki poziom bezrobocia równowagi. Państwo powinno zatem podjąć działania niezbędne do ograniczenia skali tego zjawiska poprzez: poprawę jakości usług pośrednictwa pracy, zmniejszenie kosztów przyjęć i zwolnień z pracy, zwiększenie mobilności wewnętrznej siły roboczej, zmniejszenie stopy kompensacji poprzez ograniczenie hojności systemu zasiłkowego (zarówno dla bezrobotnych, jak i systemu opieki społecznej).

Analiza wpływu zmian relacji między faktyczną stopą bezrobocia a stopą bezrobocia NAIRU na stopień restrykcyjności polityki pieniężnej oraz polityki fiskalnej (przeprowadzona w piątym rozdziale) nie pozwala na wyciągnięcie jednoznacznych wniosków. Podstawowym celem polityki pieniężnej jest stabilizacja cen, dlatego też zmiany poziomu bezrobocia równowagi mogły nie wpływać w sposób istotny na jej stopień restrykcyjności. Ponadto, oszacowania NAIRU nie są precyzyjne, więc banki centralne przy podejmowaniu decyzji o kształcie polityki pieniężnej podchodzą do nich z dużą dozą ostrożności.

Jeśli chodzi o wpływ bezrobocia równowagi na stopień restrykcyjności polityki fiskalnej, to wydaje się, iż niejednoznaczne wyniki można tłumaczyć tym, że analizowany okres jest bardzo krótki i niejednorodny. Ponadto, w strukturze wydatków budżetowych w Polsce znaczący udział mają wydatki sztywne. Zmiana relacji między faktyczną stopą bezrobocia a stopą bezrobocia NAIRU mogła nie mieć znaczącego wpływu na zmianę stopnia restrykcyjności tej polityki. 


\section{Bibliografia}

Abraham K. G., Katz L. (1986), Cyclical unemployment: Sectoral shift or aggregate disturbances?, „Journal of Political Economy”, no. 94.

Adamczyk A. (2005), Makroekonomiczne uwarunkowania bezrobocia transformacyjnego w Polsce, Czechach, Stowacji i na Wegrzech, Wydawnictwo Akademii Ekonomicznej w Krakowie, Kraków.

Alogoskoufis G., Bean C., Bertola G., Cohen D., Dolado J., Saint-Paul G. (1995), Unemployment: Choices for Europe, CEPR, London.

Arendt Ł. (2006), Czy w Polsce występuje efekt histerezy bezrobocia?, „Gospodarka Narodowa”, nr $11-12$.

Balicki W., Ptaszyńska B. (2003), Strukturalne bezrobocie transformacyjne, [w:] W. Jarmołowicz (red.), Rynek pracy w warunkach zmian ustrojowych, Wydawnictwo Akademii Ekonomicznej w Poznaniu, Poznań.

Ball L. (1996), Disinflation and the NAIRU, „NBER Working Paper”, no. 5520.

Ball L., Mankiw N. G. (2002), The NAIRU in theory and practice, „NBER Working Paper”, no. 8940. Bank for International Settlements, www.bis.org/statistics/eer/index.htm (dostęp: 25.06.2012).

Barro R. J. (1997), Makroekonomia, PWE, Warszawa.

Becker G. S. (1975), Human Capital. A Theoretical and Empirical Analysis with Special Reference to Education, Columbia University Press, New York-London.

Benes J., N'Diaye P. (2004), A Multivariate Filter for Measuring Potential Output and the NAIRU: Application to The Czech Republic, „IMF Working Paper”, no. 45.

Blanchard O., Diamond P. (1992), The flow Approach to labor markets, „American Economic Review", Papers and Proceedings, vol. 80.

Blanchard O., Katz. F. (1996), What we know and do not know about the natural rate of unemployment, „NBER Working Paper”, no. 5822.

Blanchard O., Summers L. H. (1986), Hysteresis in Unemployment, „NBER Working Paper”, no. 2035.

Blanchflower D., Oswald A. (1994), The wage curve, The MIT Press, Cambridge.

Blaug M. (1994), Teoria ekonomii. Ujęcie retrospektywne, Wydawnictwo Naukowe PWN, Warszawa.

Blaug M. (1995), Metodologia ekonomii, Wydawnictwo Naukowe PWN, Warszawa.

Bludnik I. (2006), Hipoteza naturalnej stopy bezrobocia w ujęciu Edmunda S. Phelpsa i Miltona Friedmana, [w:] M. Ratajczak (red.), Teoretyczne podstawy polityki gospodarczej, „Zeszyty Naukowe", 77, Wydawnictwo Akademii Ekonomicznej w Poznaniu.

Bludnik I. (2010), Neokeynesizm. Analiza krytyczna, Wydawnictwo Uniwersytetu Ekonomicznego w Poznaniu, Poznań.

Broniatowska P., Gajewski P., Rogut A. (2011), Rynek pracy w makroregionie wschodnim, www.

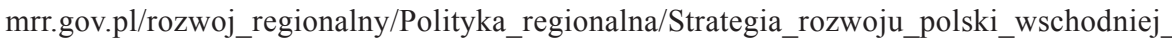
do_2020/Dokumenty/Documents/rynek_pracy.pdf (dostęp: 15.12.2012).

Budnik K. (2008), Non-accelerating wage inflation rate of unemployment in Poland, „Working Papers", no. 48, National Bank of Poland, Economic Institute. 
Bukowski M., Lewandowski P., Magda I., Zawistowski J. (2006), Praca i wzrost, [w:] M. Bukowski (red.), Zatrudnienie w Polsce 2005, Ministerstwo Gospodarki i Pracy, Departament Analiz i Prognoz Ekonomicznych, Warszawa.

Camarero M., Carrion-i-Silvestre J., Tamarit C. (2005), Unemployment dynamics and NAIRU estimates for CEECs: A univariate approach, Documents de Treball De la Facultat de Cičncies Econňomiques i Empresarials.

Carlin W., Soskice D. (1990), Macroeconomics of the Wage Bargain, Oxford University Press, Oxford.

Carline D., Pissarides Ch. A., Siebert W. S., Sloane P. J. (1985), Labour Economics, Longman, London and New York.

Charemza W. W., Deadman D. F. (1997), Nowa ekonometria, PWE, Warszawa.

Chick V. (1983), Macroeconomics after Keynes: A Reconsideration of the General Theory, Phillip Allan, Deddington, Oxford.

Chow G. C. (1995), Ekonometria, PWN, Warszawa.

Christiansen B. (2002), Reservation Wages, Offered Wages, and Unemployment Duration - New Empirical Evidence, „Kiel Working Paper”, no. 1095.

Creedy J. (red.) (1981), The Economics of Unemployment in Britain, Butterworths, London.

Daly M., Hobijn B., Valletta R. (2011), The Recent Evolution of the Natural Rate of Unemployment, IZA, ,Discussion Paper”, no. 5832.

Daly M. C., Hobijn B., Şahin A., Valletta R. G. (2012), Rynki pracy w modelu poszukiwań $i$ dopasowań: czy naturalna stopa bezrobocia rzeczywiście wzrosła?, „Gospodarka Narodowa", nr 11-12.

Darby M., Haltiwanger J. C., Plant M. (1985), Unemployment Rate Dynamics and Persistent Unemployment under Rational Expectations, „NBER Working Papers”, no. 1558.

Demchuk O., Łyziak T., Przystupa J., Sznajderska A., Wróbel E. (2012), Mechanizm transmisji polityki pieniężnej w Polsce. Co wiemy w 2011 roku?, Narodowy Bank Polski, „Materiały i Studia. Zeszyt", nr 270, Warszawa.

Domański S. R. (1993), Kapitał ludzki i wzrost gospodarczy, Wydawnictwo Naukowe PWN, Warszawa.

Ehrenberg R. G., Smith R. S. (1991), Modern Labour Economics. Theory and Public Policy, Harper Collins Publishers Inc., New York.

Ehrenberg R. G., Smith R. S. (1994), Modern Labour Economics: Theory and Public Policy, Harper Collins College Publishers, New York.

Eisner R. (1995), Our NAIRU Limit. The Governing Myth of Economic Policy, „American Prospect", vol. 6, no. 21 .

Elliott R. F. (1990), Labour Economics: A Comparative Text, McGraw-Hill Book Company.

Elmeskov J. (1994), Nordic Unemployment in a European Perspective, „Swedish Economic Policy Review", 1.

Elmeskov J., MacFarland M. (1993), Unemployment Persistence, „OECD Economic Studies”, 21.

Estrella A., Miszkin F. S. (1998), Rethinking the Role of NAIRU in Monetary Policy: Implications of Model Formulation and Uncertainty, „NBER Working Paper”, no. 6518.

Fitzenberger B., Franz W., Bode O. (2007), The Phillips Curve and NAIRU Revisited: New Estimates for Germany, „Discussion Paper”, no. 07-070, Centre for European Economic Research, Mannheim.

Flek V., Večernik J. (2004), The Labour Market in the Czech Republic: Trends, Policies and Attitudes, [w:] V. Flek (red.), Anatomy of the Czech Labour Market: From Over-Employment to Under-employment in ten Years, Czech National Bank, „Working Paper Series”, no. 7.

Friedman B. L. (red.) (2002), Inflacja, bezrobocie a polityka monetarna, Wydawnictwo CeDeWu, Warszawa. 
Friedman M. (1968), The role of monetary policy, „The American Economic Review”, vol. 58, no. 1.

Friedman M. (1975), Rola polityki pieniężnej, [w:] Teoria i polityka stabilizacji koniunktury. Wybór tekstów, oprac. A. Szeworski, PWE, Warszawa.

Friedman M. (1977), Nobel Lecture: Inflation and Unemployment, „Journal of Political Economy”, vol. 85 , no. 3 .

Galbraith J. K. (1997), Time to Ditch the NAIRU, „Journal of Economic Perspectives”, vol. 11, no. 1.

Galbraith J. K. (2002), Komentarze, [w:] B. L. Friedman (red.), Inflacja, bezrobocie a polityka monetarna, Wydawnictwo CeDeWu, Warszawa.

Gärtner M. (1997), A Primer in European Macroeconomics, Prentice Hall, London.

Gärtner M. (2006), Macroeconomics, wyd. 2, Prentice Hall, London.

Godłów-Legiędź J. (2008), Strukturalistyczna teoria zatrudnienia Edmunda Phelpsa, „Gospodarka Narodowa", nr 9.

Godłów-Legiędź J. (2010), Współczesna ekonomia. Ku nowemu paradygmatowi?, Wydawnictwo C. H. Beck, Warszawa.

Gordon R. J. (1996), The Time-Varying NAIRU and its Implications for Economic Policy, „NBER Working Paper", no. 5735.

Gordon D. M. (1988), The un-natural Rate of Unemployment: An Econometric Critique of The NAIRU Hypothesis, „American Economic Review”, vol. 78, no. 2.

Góra M., Walewski M. (2002), Bezrobocie równowagi w Polsce - wstępna analiza i próba oszacowania, „Prawo i Gospodarka”, 4 (15).

Gradzewicz M. (2011), Naturalna stopa bezrobocia, [w:] A. Sławiński (red.), Polityka pieniężna, Wydawnictwo C. H. Beck, Warszawa.

Gradzewicz M., Kolasa M. (2004), Szacowanie luki popytowej dla gospodarki polskiej przy wykorzystaniu metody VECM, „Bank i Kredyt”, $\mathrm{nr} 2$.

Gradzewicz M., Strzelecki P. (2011), Kreacja i destrukcja miejsc pracy w polskiej gospodarce w świetle publikowanych danych miesięcznych, „Bank i Kredyt”, t. 42, nr 5.

Greenwald B. C., Stiglitz J. E. (1995), Labor-Market Adjustments and the Persistence of Unemployment, „The American Economic Review”, Papers and Proceedings, vol. 85, no. 2.

Gumuła W., Socha J., Wojciechowski W. (2007), Presja płacowa oraz niedopasowanie strukturalne na rynku pracy w świetle badań NBP, Narodowy Bank Polski, „Materiały i Studia. Zeszyt”, nr 219, Warszawa.

GUS (2001), Rocznik Statystyczny Pracy 2001, Warszawa.

GUS (2003), Rocznik Statystyczny Pracy 2003, Warszawa.

GUS (2007), Polska Klasyfikacja Działalności 2007, www.stat.gov.pl/klasyfikacje/pkd_07/pkd_07. htm (dostęp: 3.02.2014).

GUS (2008), Aktywność ekonomiczna ludności Polski I-IV kwartat 2007, Warszawa.

GUS (2012a), Aktywność ekonomiczna ludności Polski I kwartat 2012, Warszawa.

GUS (2012b), Informacja o rozmiarach i kierunkach emigracji z Polski w latach 2004-2011, Departament Badań Demograficznych, Warszawa, strona internetowa GUS: www.stat.gov.pl (dostęp: 25.03.2014).

GUS (2013a), Aktywność ekonomiczna ludności Polski IV kwartał 2012, Warszawa.

GUS (2013b), Bezrobocie rejestrowane w Polsce I-IV kwartat 2012, Warszawa.

GUS, Bank Danych Lokalnych, www.stat.gov.pl (dostęp: 25.03.2014).

GUS, Bezrobocie rejestrowane w Polsce, różne wydania z lat 1995-2013, Warszawa.

Hall R. E. (1979), A Theory of the Natural Unemployment Rate and the Duration of Employment, „Journal of Monetary Economics”, no. 5.

Hall R. E., Taylor J. B. (2000), Makroekonomia, Wydawnictwo Naukowe PWN, Warszawa. 
Haltiwanger J. C. (1987), The Natural Rate of Unemployment, [w:] The New Palgrave, A Dictionary of Economics, vol. 3, The Macmillan Press LTD, London.

Holt C. C. (1970), Job Search, Phillips' Wage Relation, and Union Influence: Theory and Evidence, [w:] E. S. Phelps (i in.) (red.), Microeconomic foundations of employment and inflation theory, W. W. Norton \& Company, New York.

Howitt P. (1988), Business Cycles with Costly Search and Recruiting, „Quarterly Journal of Economics", vol. CIII.

Howitt P., McAfee P. (1987), Costly Search and Recruiting, „International Economic Review”, vol. 28 , no. 1 .

Hudson J. R. (1988), Unemployment after Keynes: towards a new general theory, Harvester, Wheatsheaf, Saint Martin's Press, New York.

Hughes J. J., Perlman R. (1984), The Economics of Unemployment. A Comparative Analysis of Britain and the United States, Wheatsheaf Books Ltd., Brighton.

Hurník J. (2005), Potential Output: What Can Production Function Tell US?, „Economic Research Bulletin”, Czech National Bank, vol. 3, no. 1.

Hurník J., Navrátil D. (2004), Labour Market Performance and Macroeconomic Policy: The Time Varying NAIRU in The Czech Republic, [w:] V. Flek (red.), Anatomy of the Czech Labour Market: From Over-employment to Under-employment in ten Years, Czech National Bank, „Working Paper Series”, no. 7.

Irac D. (2000), Estimation of a Time Varying NAIRU for France, strona internetowa Banku Francji: www.banque-france.fr (dostęp: 25.03.2014).

Jackman R., Layard R., Savouri S. (1991), Mismatch: A Framework for Thought, [w:] P. F. Schioppa (red.), Mismatch and Labour Mobility, CEPR, Cambridge University Press, Cambridge.

Jackman R., Roper R. (1987), Structural Unemployment, „Oxford Bulletin of Economics and Statistics", no. 1.

James E. (1958), Historia myśli ekonomicznej XX wieku, Państwowe Wydawnictwo Naukowe, Warszawa.

Jarmołowicz W. (2013), Rynek pracy i polityka państwa na rynku pracy w Polsce okresu transformacji i integracji gospodarczej, [w:] E. Kwiatkowski, W. Kasperkiewicz (red.), Gospodarka w okresie globalnego kryzysu, „Acta Universitatis Lodziensis. Folia Oeconomica”, nr 281, Łódź.

Jarmołowicz W., Woźniak B. (2005), Bezrobocie równowagi a polityka państwa na rynku pracy, [w:] D. Kopycińska (red.), Teoretyczne aspekty gospodarowania, Katedra Makroekonomii Uniwersytetu Szczecińskiego, Szczecin.

Jarmołowicz W., Woźniak B. (2006), Transformacyjne bezrobocie instytucjonalne, [w:] D. Kopycińska (red.), Bezrobocie we wspótczesnych gospodarkach rynkowych, Katedra Mikroekonomii Uniwersytetu Szczecińskiego, Szczecin.

Johansen S. (1995), Likelihood-Based Inference in Cointegrated Vector Autoregressive Models, Oxford University Press, Oxford.

Józefiak C., Krajewski P., Mackiewicz M. (2006), Deficyt budżetowy. Przyczyny i metody ograniczania, PWE, Warszawa.

Kaźmierczak A. (2008), Polityka pieniężna w gospodarce otwartej, Wydawnictwo Naukowe PWN, Warszawa.

Kaźmierczak Z. (1995), Rynek pracy w państwach wysoko rozwiniętych. Analiza porównawcza, Wydawnictwo Uniwersytetu Łódzkiego, Łódź.

Kelm R. (2009), Ekonometryczny szacunek NAIRU/NAWRU dla Polski na podstawie krzywej Phillipsa, [w:] W. Kwiatkowska (red.), Bezrobocie równowagi w gospodarce polskiej. Szacunki, tendencje i determinanty, Wydawnictwo Uniwersytetu Łódzkiego, Łódź. 
Koning J., Gerderblom A., Van der Weijde I. (1994), Education as an input factor in a production function, Papers for the Six Annual EALE Conference, vol. VIII, Warszawa.

Kot A. (2003a), Metody kwantyfikacji restrykcyjności polityki monetarnej, fiskalnej oraz policy mix w krajach akcesyjnych, „Bank i Kredyt”, nr 6.

Kot A. (2003b), Restrykcyjność monetarna, fiskalna oraz policy mix w Polsce, Czechach $i$ na Wegrzech, „Bank i Kredyt”, nr 7.

Krajewski P. (2006), Strukturalny i cykliczny komponent deficytu budżetowego w Polsce, Wydawnictwo Uniwersytetu Łódzkiego, Łódź.

Kryńska E. (1996), Segmentacja rynku pracy. Podstawy teoretyczne i analiza statystyczna, Wydawnictwo Uniwersytetu Łódzkiego, Łódź.

Kucharski L. (2002), Przepływy siły roboczej w Polsce w latach dziewięćdziesiątych, Katedra Ekonomii UŁ, Łódź.

Kucharski L. (2006), Bezrobocie naturalne - pojęcie oraz metody pomiaru, „Zeszyt Naukowy WSFil", nr 5, Kalisz.

Kucharski L. (2009), Bezrobocie równowagi w Polsce $i$ w wybranych krajach Europy Środkowo-Wschodniej - przegląd wyników badań oraz własne oszacowana, [w:] W. Kwiatkowska (red.), Bezrobocie równowagi w gospodarce polskiej. Szacunki, tendencje i determinanty, Wydawnictwo Uniwersytetu Łódzkiego, Łódź.

Kucharski L. (2012), Polityka pieniężna a bezrobocie równowagi w Polsce, [w:] W. Kasperkiewicz, E. Kwiatkowski (red.), Innowacyjność gospodarki, rynek pracy, determinanty wzrostu gospodarczego w procesie transformacji, Wydawnictwo Uniwersytetu Łódzkiego, Łódź 2012.

Kucharski L., Kwiatkowski E. (2011), Konkurencyjność gospodarki a poziom rozwoju gospodarczego polskich województw, [w:] D. Kotlorz (red.), Dylematy współczesnego rynku pracy, Studia Ekonomiczne, Zeszyty Naukowe Wydziałowe, Uniwersytet Ekonomiczny w Katowicach, Katowice.

Kuczyński G., Strzała K. (2006), Szacowanie stopy równowagi bezrobocia dla Polski w latach 1990-2004, [w:] S. Krajewski, P. Kaczorowski, (red.), Wzrost gospodarczy, restrukturyzacja i rynek pracy. Ujęcie teoretyczne i praktyczne, Instytut Ekonomii Uniwersytetu Łódzkiego, Łódź.

Kusideł E. (2000), Modelowanie wektorowo-autoregresyjne VAR. Metodologia i zastosowania, [w:] B. Suchecki (red.), Dane panelowe i modelowanie wielowymiarowe w badaniach ekonomicznych, t. 3, Wyd. Absolwent, Łódź, www.kep.uni.lodz.pl/ewakusidel/index/2000_modele_VAR.pdf (dostęp: 25.03.2012).

Kwiatkowski E. (1988), Neoklasyczne teorie zatrudnienia. Tradycja i współczesność, PWN, Warszawa.

Kwiatkowski E. (2002a), Bezrobocie. Podstawy teoretyczne, Wydawnictwo Naukowe PWN, Warszawa.

Kwiatkowski E. (2002b), Strukturalne determinanty naturalnej stopy bezrobocia, „Bank i Kredyt”, nr $11-12$.

Kwiatkowski E. (2009), Pojęcie i determinanty bezrobocia równowagi w świetle teorii rynku pracy, [w:] W. Kwiatkowska (red.), Bezrobocie równowagi w gospodarce polskiej. Szacunki, tendencje i determinanty, Wydawnictwo Uniwersytetu Łódzkiego, Łódź.

Kwiatkowski E., Domański Cz., Kubiak P. (1999), Labour Market Policies in Poland in Transition - Forms, „Statistics in Transition”, vol. 4, no. 3.

Kwiatkowski E., Kucharski L. (2009), Bezrobocie dlugookresowe w Polsce w latach 1995-2007, [w:] M. Ratajczak (red.), Polska transformacja - między teoriq a praktyka, ,Zeszyty Naukowe", nr 118, Wydawnictwo Uniwersytetu Ekonomicznego w Poznaniu, Poznań.

Kwiatkowski E., Kucharski L., Tokarski T. (2002), Bezrobocie i zatrudnienie a PKB w Polsce w latach 1993-2001, „Ekonomista”, nr 3. 
Kwiatkowski E., Rogut A. Roszkowska S. (2009), Zjawisko histerezy a bezrobocie równowagi w Polsce, [w:] W. Kwiatkowska (red.), Bezrobocie równowagi w gospodarce polskiej. Szacunki, tendencje i determinanty, Wydawnictwo Uniwersytetu Łódzkiego, Łódź.

Kwiatkowski E., Tokarski T. (2007), Bezrobocie regionalne w Polsce w latach 1995-2005, „Ekonomista", $\mathrm{nr} 4$.

Layard R. (1986), How to beat unemployment, Oxford University Press, New York.

Layard R. (1996), The Road Back to Full Employment, „LSE CEP Occasional Papers”, no. 100, London.

Layard R., Nickell S., Jackman R. (1991), Unemployment: Macroeconomic Performance and the Labour Market, Oxford University Press, Oxford.

Layard R., Nickell S., Jackman R. (2005), Unemployment: Macroeconomic Performance and the Labour Market, Oxford University Press, Oxford.

Leszkiewicz-Kędzior K., Welfe W. (2013), Szacunek naturalnej stopy bezrobocia dla Polski, [w:] E. Kwiatkowski, W. Kasperkiewicz (red.), Gospodarka w okresie globalnego kryzysu, „Acta Universitatis Lodziensis. Folia Oeconomica”, nr 281.

Lindbeck A. (1992), Macroeconomic theory and the labor market, „European Economic Review”, no. 36 .

Lindbeck A., Snower D. J. (1986), Wage Setting, Unemployment and Insider-Outsider Relations, „American Economic Review”, vol. 76, May.

Lindbeck A., Snower D. J. (1988), The Insider-Outsider Theory of Employment and Unemployment, The MIT Press, Cambridge-Massachusetts.

Lindeboom M., Theeuwes J. (1993), Search, Benefits and Entitlement, „Economica”, vol. 60, no. 327.

Lucas R. E. (1972), Expectations and the Neutrality of Money, „Journal of Economic Theory”, no. 4, April.

Marston S. T. (1976), Employment Instability and High Unemployment Rates, „The Brookings Papers on Economic Activity", no. 1.

McKenna C. J. (1985), Uncertainty and the Labour Market: Recent Developments in Job-Search Theory, Wheatsheaf Books, Brighton.

Michałek A. (2012), Szacowanie naturalnej stopy procentowej dla Polski, Acta Universitatis Nicolai Copernici, „Ekonomia”, XLIII, nr 2.

Modigliani F., Papademos L. (1975), Targets for Monetary Policy in the Coming Year, Brookings Papers on Economic Activity, vol. 1.

OECD (1998), OECD Employment Outlook 1998, Paris.

Okun A. (1962), Potential GNP: Its Meausurement and Significance, „Procedings of the Business and Economics Statistics Section", American Statistical Association.

Petrongolo B., Pissarides C. (2001), Looking into the black box: A survey of the matching function, „Journal of Economic Literature”, no. 39.

Phelps E. S. (1967), Phillips Curves, Expectations of Inflation and Optimal Unemployment Over Time, „Economica”, no. 135.

Phelps E. S. (1970), Money, Wage Dynamics and Labour Market Equilibrium, [w:] E. S. Phelps (i in.) (red.), Microeconomic foundations of employment and inflation theory, W. W. Norton \& Company, New York.

Phelps E. S. (1995), The Origins and Further Development of the Natural Rate of Unemployment, [w:] R. Cross (red.), The Natural Rate of Unemployment. Reflections on 25 Years of the Hypothesis, Cambridge University Press.

Phelps E. S. (1998), Structural Slumps. The Modern Equilibrium Theory of Unemployment. Interest, and Assets, Harvard University Press, Cambridge. 
Phelps E. S. (2006), Prize Lecture: Macroeconomics for a Modern Economy, Nobelprize.org, Nobel Media AB 2013, www.nobelprize.org/nobel_prizes/economic-sciences/laureates/2006/phelpslecture.html (dostęp: 19.11.2013).

Pissarides Ch. A. (1997), The need for labor-market flexibility in a European economic and monetary union, „Swedish Economic Policy Review”, vol. 4, no. 2.

Pissarides Ch. A. (2012), Teoria bezrobocia w stanie równowagi, PTE, Warszawa.

Pissarides Ch. A., Wadsworth J. (1994), On-the-job search, „European Economic Review”, no. 38.

Próchnicki L. (2011), Polityka monetarna Polski w świetle bezpośredniego celu inflacyjnego, „Studia i Prace WNEiZ Uniwersytetu Szczecińskiego", nr 22.

Ramaswami Ch. (1983), Equilibrium Unemployment and the Efficient Job-Finding Rate, ,Journal of labor Economics", no. 1.

Raport o inflacji w III kwartale 2003 r. (2003), Rada Polityki Pieniężnej, NBP.

Robinson D. (1986), Monetarism and the Labour Market, Clarendon Press, Oxford.

Rogut A. (2007), Krzywa płac w gospodarce polskiej w latach 1995-2005, „Bank i Kredyt”, nr 4.

Romer D. (2000), Makroekonomia dla zaawansowanych, Wydawnictwo Naukowe PWN, Warszawa.

Samuelson P. A., Nordhaus W. D. (2012), Ekonomia, Dom Wydawniczy REBIS S. z o. o., Poznań 2012.

Sapsford D. (1981), Labour Markets Economics, George Allen \& Unwin (Publishers), London.

Sargent T. J., Wallace N. (1975), 'Rational' expectations, the optimal monetary instrument and the optimal money supply rule, ,Journal of Political Economy”, no. 2, April.

Schettkat R. (red.) (1996), The Flow Analysis of Labour Markets, Routledge, London-New York.

Snowdon B., Vane H., Wynarczyk P. (1998), Wspótczesne nurty teorii makroekonomii, Wydawnictwo Naukowe PWN, Warszawa.

Socha J., Wojciechowski W. (2004), Koncepcja NAIRU a druga fala bezrobocia w Polsce, „Bank i Kredyt", nr 3.

Socha M., Sztanderska U. (2000), Strukturalne podstawy bezrobocia w Polsce, Wydawnictwo Naukowe PWN, Warszawa.

Solow R. M. (1985), Insiders and Outsiders in Wage Determination, „Scandinavian Journal of Economics", vol. 87, no. 2.

Solow R. M. (2002), Jak ostrożny powinien być bank centralny?, [w:] B. L. Friedman (red.), Inflacja, bezrobocie a polityka monetarna, Wydawnictwo CeDeWu, Warszawa.

Staiger D., Stock J. H., Watson M. W. (1996), How Precise are Estimates of the Natural Rate of Unemployment?, „NBER Working Paper”, no. 5477.

Staiger D., Stock J. H., Watson M. W. (2001), Prices, Wages and the U.S. NAIRU in the 1990s, „NBER Working Paper”, no. 8320.

Staiger D., Stock J. H., Watson M. W. (1997), The NAIRU, unemployment and monetary policy, „Journal of Economic Perspectives”, vol. 11.

Stevens G. R. (1998), Pitfalls in the use of monetary condition indexes, ,Reserve Bank of Australia Bulletin", August.

Stigler G. J. (1961), The Economics of Information, „Journal of Political Economy”, vol. 69, no. 3.

Stigler G. J. (1962), Information in the Labour Market, „Journal of Political Economy”, vol. 70, no. 5 , part 2.

Stiglitz J. E. (1997), Reflections on the Natural Rate Hypothesis, „Journal of Economics Perspectives", vol. 11, no. 1, Winter.

Szczurek M. (2011), Polityka pieniężna w Polsce, [w:] A. Sławiński (red.), Polityka pieniężna, Wydawnictwo C. H. Beck, Warszawa.

Taylor J. B. (2002), Wytyczne dla polityki monetarnej w celu ustabilizowania poziomu zatrudnienia i inflacji, [w:] B. L. Friedman (red.), Inflacja, bezrobocie a polityka monetarna, Wydawnictwo CeDeWu, Warszawa. 
Tokarski T. (2008), Przestrzenne zróżnicowanie bezrobocia w Polsce, „Gospodarka Narodowa”, nr 7-8.

Tyrowicz J. (2011), Histereza bezrobocia w Polsce, Wydawnictwo Uniwersytetu Warszawskiego, Warszawa.

Unolt J. (1999), Ekonomiczne problemy rynku pracy, Biblioteka pracownika socjalnego, Wydawnictwo Śląsk, Katowice.

Urbańska A. (2002), Polityka monetarna: wspótczesna teoria i analiza empiryczna dla Polski, „Materiały i Studia. Zeszyt”, nr 148, Narodowy Bank Polski, Warszawa.

Ustawa z dnia 20 kwietnia 2004 r. o promocji zatrudnienia i instytucjach rynku pracy, Dz. U. 2004, nr 99, poz. 1001.

Van Ees H., Garretsen H. (1996), The Natural Rate Moves! A Review of Edmund Phelps' Structural Slumps, „De Economist” 144, vol. 1.

Wadsworth J. (1991), Unemployment Benefits and Search Effort in the U. K. Labour Market, „Economica", vol. 58, no. 229.

Welfe A. (2003), Ekonometria, PWE, Warszawa.

Wernik A. (2002), Problemy polityki fiskalnej w kreowaniu policy mix, „Bank i Kredyt”, t. 33, nr $11-12$.

Winiarski B. (2000), Polityka gospodarcza, Wydawnictwo Naukowe PWN, Warszawa.

Wiśniewski Z. (2011), Podstawy aktywnej polityki rynku pracy, [w:] Z. Wiśniewski, K. Zawadzki (red.), Efektywność polityki rynku pracy w Polsce, Pracownia Sztuk Plastycznych Sp. z o.o., Toruń.

Wiśniewski Z., Dolny E., Jaskólska B., Maksim M., Śliwicki D., Wojdyło-Preisner M., Zawadzki K. (2011), Efektywność aktywnej polityki rynku pracy w świetle badań empirycznych, www.almp. umk.pl/public/pl/files/File/Publikacje/efektywnosc_APRP_badania_empiryczne.pdf, Toruń (dostęp: 16.09.2013).

Wojtyna A. (1994), Czy Polsce grozi efekt histerezy, „Gospodarka Narodowa”, nr 9.

Wojtyna A. (2000), Ewolucja keynesizmu a główny nurt ekonomii, Wydawnictwo Naukowe PWN, Warszawa.

Wojtyna A. (2003), Polityka makroekonomiczna w cyklu koniunkturalnym - nowe nurty w teorii, "Gospodarka Narodowa", nr 5-6.

Wojtyna A. (2004), Skuteczność polityki pieniężnej, cykl wykładów dziekańskich: Gospodarka i społeczeństwo, Wydawnictwo Uniwersytetu Łódzkiego, Łódź.

Woźniak B. (2008), Bezrobocie równowagi i nierównowagi a polityka państwa wobec rynku pracy, Wydawnictwo Akademii Ekonomicznej w Poznaniu, Poznań.

Wrońska A. (2005), Meklenburgia - Pomorze Przednie - niemiecki partner Polski w euroregionie „Pomerania”, „Polityka Społeczna”, nr 1. 


\section{Spis tabel, wykresów i rysunków}

\section{Tabele}

Tabela 1.1. Stopy bezrobocia w wybranych krajach Europy Zachodniej i USA w latach 1980-1985 (w \%)

Tabela 2.1. Oszacowania ilorazów prawdopodobieństw bycia bezrobotnym długookresowo w Polsce w 2006 r.

Tabela 2.2. Oszacowania ilorazów prawdopodobieństw bycia bezrobotnym długookresowo w Polsce w IV kwartale 2010 r.

Tabela 2.3. Stopy bezrobocia w wybranych grupach sily roboczej w latach $1995-2012^{a}$ (w \%)

Tabela 2.4. Dynamika liczby bezrobotnych według województw w latach 2001-2012* $($ rok $2000=100)$

Tabela 2.5. Miary zróżnicowania stóp bezrobocia według województw w latach 2000-2012

Tabela 2.6. Województwa o najniższym poziomie stóp bezrobocia w latach 2000-2012 (według stanu w IV kwartale, w \%)

Tabela 2.7. Województwa o najwyższym poziomie stóp bezrobocia w latach 2000-2012 (według stanu w IV kwartale, w \%)

Tabela 2.8. Napływy migracyjne (wewnętrzne) na 1000 mieszkańców ogółem oraz według płci w Polsce w latach 1995-2012 (w osobach)

Tabela 2.9. Saldo migracji zagranicznych na pobyt stały na 1000 mieszkańców ogółem oraz według płci w Polsce w latach 1995-2012

Tabela 2.10. Miary płynności zasobu bezrobocia w Polsce w latach 1995-2012 ..................... 97

Tabela 2.11. Oszacowania indeksu $M 3$ w wybranych przekrojach dla lat 1995-2012 (w \%) .... 101

Tabela 2.12. Oszacowania indeksów $M 1$ i $M 2$ według województw w latach 1999-2004 oraz w latach 2011-2012 (w \%)

Tabela 2.13. Oszacowania indeksu M4 według sekcji PKD w Polsce w latach 2001-2007 (w \%)

Tabela 3.1. Przedziały czasowe, w których dokonano estymacji NAIRU w poszczególnych krajach Europy Środkowo-Wschodniej

Tabela 3.2. Oszacowania NAIRU dla krajów Europy Środkowo-Wschodniej w latach 1992-2003 (estymacja punktowa)

Tabela 3.3. Szacunki bezrobocia NAIRU oraz faktyczna stopa bezrobocia w Czechach w latach 1996-2003 (w \%)

Tabela 4.1. Stopy bezrobocia równowagi oraz rzeczywista stopa bezrobocia w Polsce w latach 1993-2001 według szacunków M. Góry i M. Walewskiego (w \%)

Tabela 4.2. Stopy bezrobocia równowagi oraz rzeczywista stopa bezrobocia w Polsce w latach 1992-1998 według szacunków M. Sochy i U. Sztanderskiej (w \%) ....... 133

Tabela 4.3. Testowanie liczby opóźnień w modelu VAR ......................................................... 149

Tabela 4.4. Wyniki testu wykluczeń dla modelu VAR z trendem ............................................ 149 
Tabela 4.5. Wyniki estymacji modelu VAR z dodanym trendem .......................................... 150

Tabela 4.6. Model VAR: zmienna $P M$ słabo egzogeniczna .................................................. 152

Tabela 4.7. Model VAR: wyniki estymacji dla dwóch wektorów kointegrujących ................... 153

Tabela 4.8. Model VAR: wyniki estymacji dla dwóch wektorów kointegrujących z nałożonymi restrykcjami strukturalizującymi ................................................ 155

Tabela 4.9. Model VAR: ostateczne wyniki estymacji ......................................................... 156

Tabela A1. Wyniki estymacji modelu z nieograniczonym wyrazem wolnym ......................... 163

Tabela A2. Statystyki dotyczące reszt w modelu z uwzględnieniem linii trendu ...................... 164

Tabela A3. Wyniki testu śladu oraz oszacowania macierzy towarzyszącej w modelu VAR ze zmiennymi zero-jedynkowymi ..................................................................... 168

Tabela A4. Model VAR z trendem i zmiennymi zero-jedynkowymi - wyniki testu of exclusion i testu stacjonarności zmiennych ................................................................ 169

Tabela A5. Model VAR z trendem i zmiennymi zero-jedynkowymi - wyniki testu egzogeniczności zmiennych ...................................................................... 169

Tabela A6. Model VAR bez zmiennych zero-jedynkowych: wyniki testów ............................ 170

\section{Wykresy}

Wykres 2.1. Liczba bezrobotnych zarejestrowanych w urzędach pracy oraz według BAEL w Polsce w latach 1995-2012 (w tys. osób)

Wykres 2.2. Stopy bezrobocia rejestrowanego i według BAEL w Polsce w latach 1995-2012

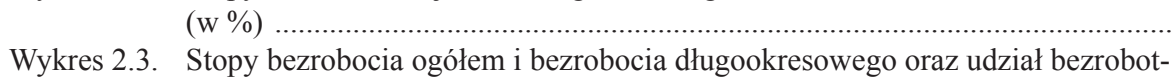

Wykres 2.4. Stopy przepływów międzywojewódzkich* w Polsce w latach 1995-2012

\section{(w \%)}

Wykres 2.5. Liczba emigrantów z Polski na pobyt czasowy w latach 2004-2011

(w tys. osób)

Wykres 4.1. Szacunki NAWRU oraz rzeczywista stopa bezrobocia według BAEL w latach 1994-2006

\section{Wykres 4.2.}

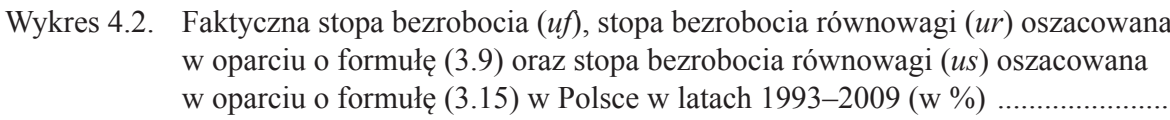
136

Wykres 4.3. Relacja między stopami bezrobocia równowagi (ur) oraz (us) a stopą bezrobocia faktycznego (uf) w Polsce w latach 1993-2009

Wykres 4.4a. Wydajność pracy (w cenach stałych z 2000 r.) oraz jej pierwsze przyrosty, I kwartał 1995 - II kwartał 2011 r. (w mln zł)

Wykres 4.4b. Przeciętne wynagrodzenie w ujęciu realnym oraz jego pierwsze przyrosty, I kwartał 1995 - II kwartał 2011 r. (w zl)

Wykres 4.4c. Przyrost CPI oraz jego pierwsze przyrosty, I kwartał 1995 - II kwartał $2011 \mathrm{r}$.

Wykres 4.4d. Stopy bezrobocia według BAEL oraz ich pierwsze przyrosty, I kwartał 1995 - II kwartał $2011 \mathrm{r}$.

Wykres 4.4e. Wskaźniki cen transakcyjnych importu (2000 r. = 100) oraz ich pierwsze przyrosty, I kwartał 1995 - II kwartał 2011 r.

Wykres 4.5. Oszacowania krótkookresowej stopy bezrobocia NAIRU*, III kwartał 1995 - II kwartał 2011 r. (w \%)

Wykres 4.6. Faktyczne stopy bezrobocia według BAEL oraz wygładzone stopy bezrobocia NAIRU (uro), III kwartał 1995 - II kwartał 2011 r. (w \%) 
Wykres 4.7. Faktyczne stopy bezrobocia według BAEL oraz różnica między faktyczną stopą bezrobocia a wygładzoną stopą bezrobocia NAIRU (uro), III kwartał 1995

- II kwartał $2011 \mathrm{r}$.

Wykres 4.8. Zależność między wygładzoną stopą bezrobocia NAIRU a współczynnikami aktywności zawodowej w Polsce, III kwartał 1995 - II kwartał 2011 r. (w \%) ..... 160

Wykres 4.9. Zależność między wygładzoną stopą bezrobocia NAIRU a udziałem bezrobotnych długookresowo w bezrobociu ogółem w Polsce, III kwartał 1995

- II kwartał 2011 r. (w \%)

Wykres A1. Model VAR: reszty empiryczne w modelu z trendem ….................................. 165

Wykres A2. Model VAR: wektory kointegrujące w modelu przed nałożeniem restrykcji ....... 172

Wykres A3. Model VAR: wektory kointegrujące z nałożonymi restrykcjami ........................ 175

Wykres 5.1. Poziom realnych stóp procentowych i realnego kursu walutowego (rok 2010 = 100) $\mathrm{w}$ Polsce $\mathrm{w}$ okresie I kwartał 1997 - II kwartał $2011 \mathrm{r}$.

Wykres 5.2. Wartości wskaźnika MCI w Polsce w okresie I kwartał 1997 - II kwartał $2011 \mathrm{r}$.

Wykres 5.3. Realna stopa procentowa i wskaźnik $C P I^{a}$ w Polsce, I kwartał 1997 - II kwartał $2011 \mathrm{r}$.

Wykres 5.4. Stopa bezrobocia NAIRU ${ }^{a}$ oraz wskaźnik $C P I^{b}$ w Polsce w okresie I kwartał 1997 - II kwartał $2011 \mathrm{r}$

Wykres 5.5. Zależność między poziomem indeksu $M C I$ a różnicą między faktyczną stopą bezrobocia (uf) a stopą bezrobocia NAIRU w Polsce, I kwartał 1997 - II kwartał $2011 \mathrm{r}$.

Wykres 5.6 Zależność między poziomem indeksu $M C I$ a różnicą między faktyczną stopą bezrobocia $(u f)$ i stopą bezrobocia NAIRU ${ }^{a}$ opóźnioną o jeden kwartał w Polsce, I kwartał 1997 - II kwartał 2011 r.

Wykres 5.7. Zależność między poziomem indeksu $M C I$ a różnicą między faktyczną stopą bezrobocia $(u f)$ i stopą bezrobocia NAIRU ${ }^{a}$ opóźnioną o dwa kwartały w Polsce, I kwartał 1997 - II kwartał $2011 \mathrm{r}$.

Wykres 5.8. Poziom deficytu budżetowego w relacji do PKB w Polsce w latach 1995-2011 $(\mathrm{w} \%)$

Wykres 5.9. Indeks restrykcyjności polityki fiskalnej FCI (w p.p.)

Wykres 5.10. Zależność między indeksem restrykcyjności polityki fiskalnej (FCI) a stopą bezrobocia NAIRU w latach 1995-2011*

Wykres 5.11. Zależność między indeksem restrykcyjności polityki fiskalnej (FCI) a różnicą między faktyczną stopą bezrobocia a stopą bezrobocia NAIRU w latach 1995-2011*

Wykres 5.12. Zależność między indeksem restrykcyjności polityki fiskalnej (FCI) a różnicą między faktyczną stopą bezrobocia a stopą bezrobocia NAIRU opóźnioną o jeden rok w latach 1995-2011*

\section{Rysunki}

Rys. 1.1. Krzywe Phillipsa wsparte oczekiwaniami oraz ich położenie w warunkach stanu stacjonarnego

Rys. 1.2. Bezrobocie naturalne a bezrobocie faktyczne ............................................................ 37

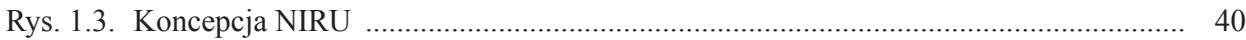

Rys. 1.4. Zależność między inflacją a bezrobociem - NAIRU .............................................. 41

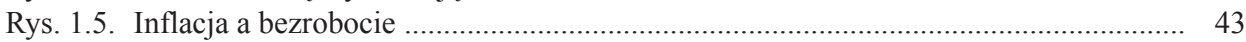

Rys. 1.6. Wpływ wzrostu presji płacowej na bezrobocie NAIRU ....................................... 47 
Rys. 1.7. Wpływ niedopasowań strukturalnych na poziom NAIRU ...................................... 49

Rys. 1.8. Wybór płacy progowej w modelu poszukiwań ....................................................... 53

Rys. 1.9. Wybór optymalnej liczby poszukiwań pracy ......................................................... 53

Rys. 1.10. Wolne miejsca pracy i stopa bezrobocia w stanie równowagi ................................ 58

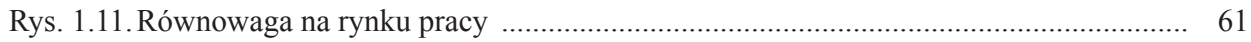

Rys. 1.12. Wpływ wzrostu cen aktywów przedsiębiorstw na naturalną stopę bezrobocia ........... 63

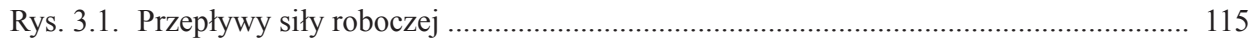

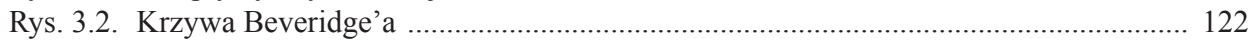




\title{
Equilibrium unemployment in Poland - a theoretical and empirical approach
}

\author{
(Summary)
}

The book focuses on defining the nature, conditions and determinants of equilibrium unemployment. It also presents the results of estimates of the level of equilibrium unemployment in the Polish economy. In addition, an attempt was made to examine the importance of variation in equilibrium unemployment for the macroeconomic policy in Poland.

The book consists of five chapters, an introduction and conclusions. In the first chapter, in addition to conceptual issues, a critical analysis of the most important concepts of equilibrium unemployment and the theory of hysteresis was conducted.

The second chapter is empirical. It presents the trends, conditions and determinants of unemployment in Poland in the years 1995-2012. The presented trends are related to changes in the level and dynamics of unemployment, as well as the level of long-term unemployment. In addition, an attempt was made to answer the question what labour groups were most at risk of long-term unemployment in the period considered. An analysis of differences in unemployment rates in selected groups of the workforce and an analysis of spatial variation in unemployment were carried out. The chapter also presents a discussion on the level of labour mobility and shows changes in the level of structural mismatches in the labour market in Poland.

The third chapter is devoted to the presentation of methods for estimating equilibrium unemployment. This section also includes an analysis of previous estimates of equilibrium unemployment in selected countries of Central and Eastern Europe.

The fourth chapter is empirical. It comprises the results of equilibrium unemployment estimates made by Polish economists, as well as the author's own estimates of equilibrium unemployment rate (NAIRU) formulated on the basis of: the flows method and the extended Phillips curve.

In the fifth chapter, an attempt was made to answer the question whether changes in the relationship between the actual unemployment rate and equilibrium unemployment rate affect the level of restrictiveness of the fiscal and monetary policy in Poland. 
The theoretical analyses indicate that the level of equilibrium unemployment depends on real factors, which may include, among others: the efficiency of the labour offices, the degree of unionization, the minimum wage, the flow of information about job vacancies, the amount of unemployment benefits and their duration, the structure of the labour force, the cost of labour, wage flexibility, the cost of training, the level of labour mobility, technology, productivity and changes in the structure of production, as well as the cost of gathering information about available workforce.

The empirical analyses indicate that the NAIRU (estimated on the basis of the extended Phillips curve) amounted to $9,8 \%$ at the end of the fourth quarter of 1995 and 15,1 at the end of the fourth quarter of 2000. At the turn of 2003 and 2004, the NAIRU in Poland reached a peak in the period analysed - 19,3\%. In subsequent years, with the improvement in the labour market, the NAIRU decreased. In the fourth quarter of 2008 , the NAIRU was $11,3 \%$ while in the second quarter of 2011 it was $7,8 \%$.

The analysis of the impact of changes in the relationship between the actual unemployment rate and the NAIRU on the degree of restrictiveness of the monetary policy and fiscal policy (carried out in chapter five) does not allow to draw firm conclusions. It should be noted, however, that the primary objective of monetary policy is price stability, therefore changes in the equilibrium unemployment level might not affect significantly the degree of its restrictiveness.

As for the impact of equilibrium unemployment on the level of restrictiveness of the fiscal policy, it seems that the ambiguous results can be explained by the fact that the analysed period is very short and heterogeneous. In addition, a significant share of fixed expenditures can be observed in the structure of budgetary expenditures in Poland. The change in the relationship between the actual unemployment rate and the NAIRU might not have a significant effect on the change in the degree of restrictiveness of this policy. 


\section{Od Redakcji}

Leszek Kucharski urodził się w 1967 r. W latach 1987-1992 studiował na Wydziale Ekonomiczno-Socjologicznym Uniwersytetu Łódzkiego na kierunku „Planowanie i finansowanie gospodarki narodowej”. W 1992 r. uzyskał tytuł magistra nauk ekonomicznych. W latach 1992-2000 pracował w Instytucie Ekonomii na Wydziale Ekonomiczno-Socjologicznym na stanowisku asystenta.

W 2000 r. obronił pracę doktorską pt. Przeptywy sity roboczej między zatrudnieniem, bezrobociem i biernościa zawodowa w Polsce w latach dziewięćdziesiatych. Od 2000 r. jest zatrudniony na stanowisku adiunkta w Instytucie Ekonomii UŁ.

W latach 1995-2013 brał udział w wielu krajowych i międzynarodowych programach badawczych kierowanych m.in. przez prof. dr. hab. Eugeniusza Kwiatkowskiego, prof. dr hab. Elżbietę Kryńską oraz prof. dr hab. Annę Organiściak-Krzykowską.

Leszek Kucharski jest doświadczonym nauczycielem akademickim, posiadającym bogaty dorobek dydaktyczno-wychowawczy i naukowy. Jest autorem i współautorem około 90 artykułów naukowych opublikowanych m.in. w „Ekonomiście”, „Gospodarce Narodowej” oraz „Wiadomościach Statystycznych”.

Zainteresowania naukowe Leszka Kucharskiego koncentrują się na problematyce zatrudnienia, bezrobocia oraz polityki gospodarczej. Jego dorobek publikacyjny ściśle wiąże się z tymi zagadnieniami. 
